WSRC-TR-2000-00338

SRT-RPP-2000-00017

\title{
Hanford Waste Simulants Created to Support the Research and Development on the River Protection Project - Waste Treatment Plant
}

Westinghouse Savannah River Company

Savannah River Site

Aiken, SC 29808

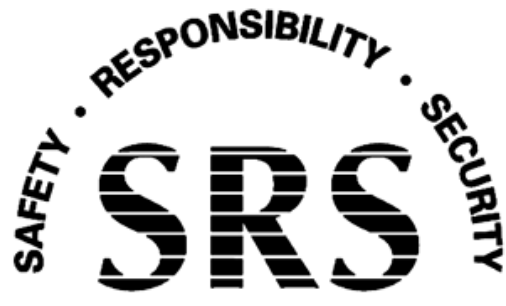

SAVANNAH RIVER SITE

Prepared for the U.S. Department of Energy under Contract No. DE-AC09-96SR18500 
This document was prepared in conjunction with work accomplished under Contract No.

DE-AC09-96SR18500 with the U.S. Department of Energy.

\section{DISCLAIMER}

This report was prepared as an account of work sponsored by an agency of the United States Government. Neither the United States Government nor any agency thereof, nor any of their employees, makes any warranty, express or implied, or assumes any legal liability or responsibility for the accuracy, completeness, or usefulness of any information, apparatus, product or process disclosed, or represents that its use would not infringe privately owned rights. Reference herein to any specific commercial product, process or service by trade name, trademark, manufacturer, or otherwise does not necessarily constitute or imply its endorsement, recommendation, or favoring by the United States Government or any agency

thereof. The views and opinions of authors expressed herein do not necessarily state or reflect those of the United States Government or any agency thereof.

This report has been reproduced directly from the best available copy.

Available for sale to the public, in paper, from: U.S. Department of Commerce, National Technical Information Service, 5285 Port Royal Road, Springfield, VA 22161, phone: (800)

553-6847, fax: (703) 605-6900, email: orders@ntis.fedworld.gov online ordering: http://www.ntis.gov/ordering.htm

Available electronically at http://www.doe.gov/bridge

Available for a processing fee to U.S. Department of Energy and its contractors, in paper, from: U.S. Department of Energy, Office of Scientific and Technical Information, P.O. Box 62, Oak Ridge, TN 37831-0062, phone: (865 ) 576-8401, fax: (865) 576-5728, email: reports@ adonis.osti.gov 
WSRC-TR-2000-00338

SRT-RPP-2000-00017

KEYWORDS:

Hanford River Protection Project

Simulants

Hanford Waste Tanks

RETENTION - Permanent

\section{Hanford Waste Simulants Created to Support the Research and Development on the River Protection Project - Waste Treatment Plant}

SAVANNAH RIVER TECHNOLOGY CENTER

Russell E. Eibling and Charles A. Nash

Publication Date: February 2001

Westinghouse Savannah River Company

Savannah River Site

Aiken, SC 29808

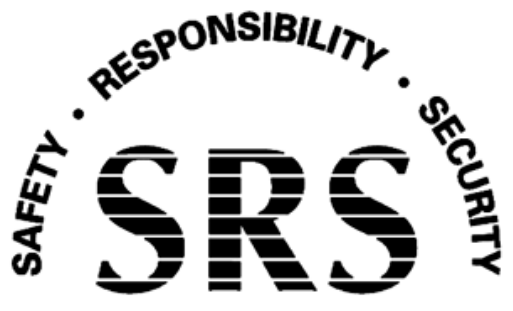

SAVANNAH RIVER SITE

Prepared for the U.S. Department of Energy under Contract No. DE-AC09-96SR18500 
DOCUMENT: $\quad$ WSRC-TR-2000-00338 (SRT-RPP-2000-00017)

TITLE:

Hanford Waste Simulants Created to Support the Research and Development on the River Protection Project - Waste Treatment Plant

\section{APPROVALS}

Date:

Russell E. Eibling, Co-author (ITD/WTT/SRTC)

Date:

Charles A. Nash, Co-author (WPT/WTT/SRTC)

Date:

Steve T. Wach, RPP Pretreatment Manager (EP Group/SRTC)

Date:

Harold F. Sturm, Jr., RPP Program Manager (WPTS/SRTC)

Date:

T. Bond Calloway, Jr., Technical Reviewer (ITS/SRTC) 


\section{TABLE OF CONTENTS}

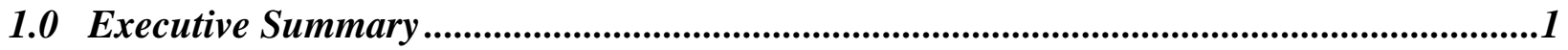

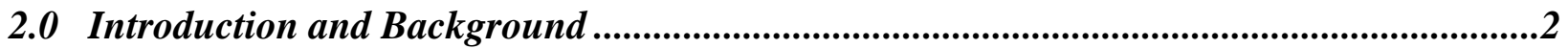

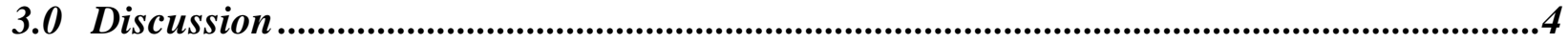

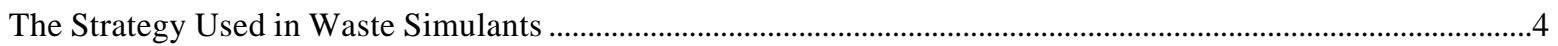

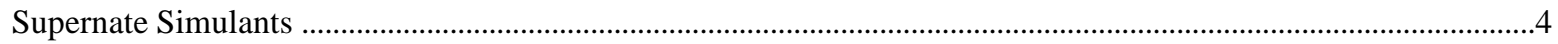

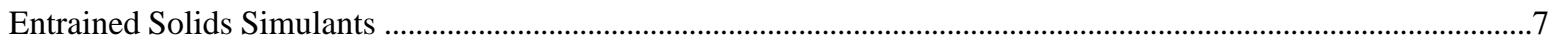

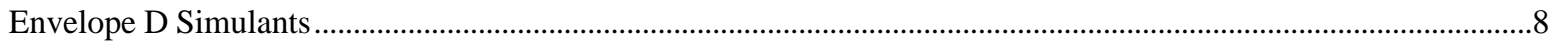

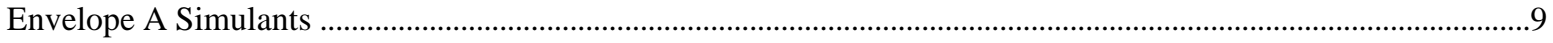

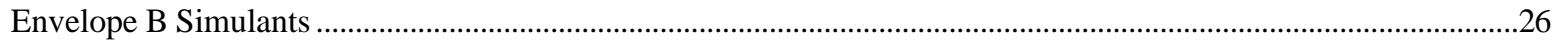

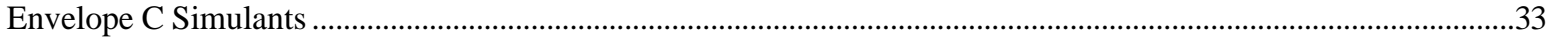

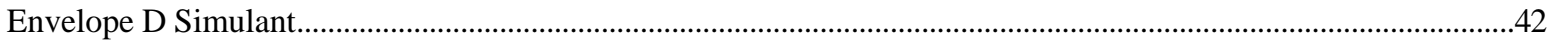

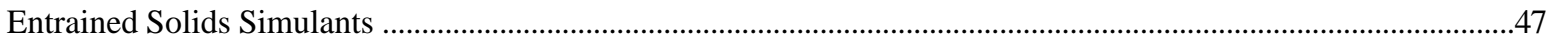

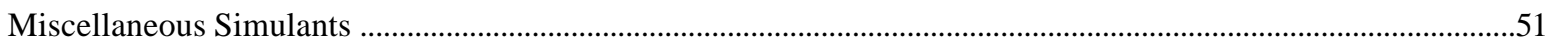

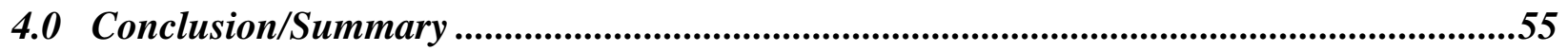

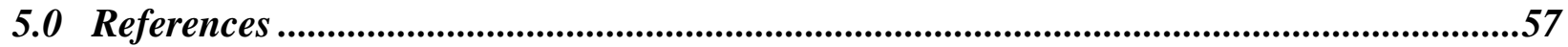

Appendixes ................................................................................................................................

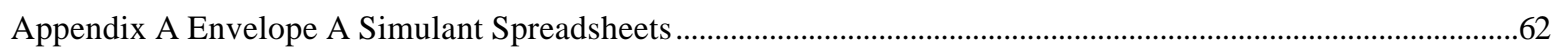

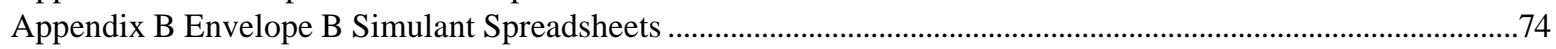

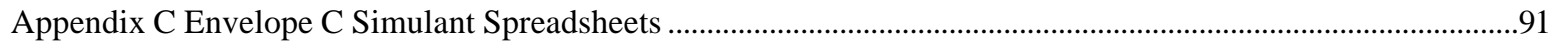

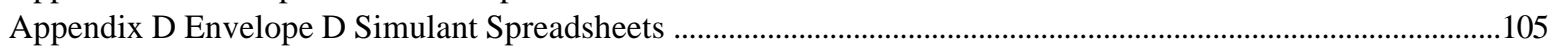

Appendix E Envelope A Entrained Solids Simulant Spreadsheet............................................................................135

Appendix F Envelope C Entrained Solids Simulant Spreadsheet .........................................................................136

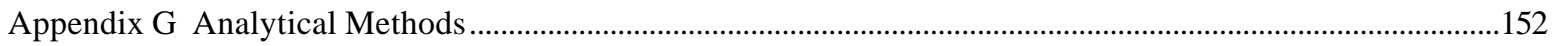




\section{LIST OF TABLES}

TABLE 1 APPROVED ENVELOPE A SIMULANT BASED ON TANK 241-AN-105 ………………………………………......10

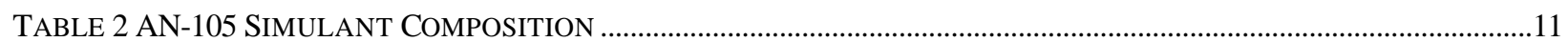

TABLE 3 ANALYTICAL RESULTS ON AN-105 SIMULANT ……………………………………………………………...12

TABLE 4 AN-105 SIMULANT DENSITY AND PERCENT SOLIDS...............................................................................................13

TABLE 5 AN-105 FIFTY VOLUME \% DiLUTION WhOLE TANK COMPOSITE SIMULANT .................................................16

TABle 6 PlanNed AN-105 FifTy Volume \% Dilution WhOle TANK COMPOSITE Simulant COMPOSITION...17

TABLE 7 AN-104 FIFTY VOLUME \% DILUTION WHOLE TANK COMPOSITE SIMULANT ………………………………....18

TABLE 8 AN-104 FIFTY VOLUME \% DILUTION WhOLE TANK COMPOSITE SIMULANT COMPOSITION ........................19

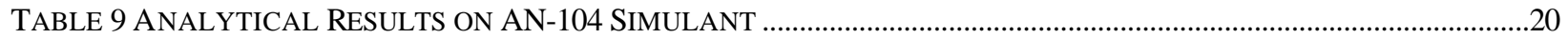

TABLE 10 BASIS FOR AW-101 SIMULANT ……………………………………………………………………….......2

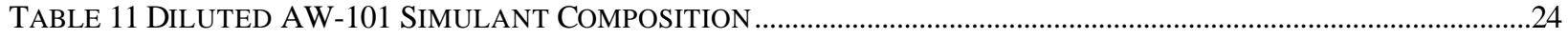

TABLE 12 ANALYTICAL RESULTS FOR AW-101 SIMULANT ………………………….................................................

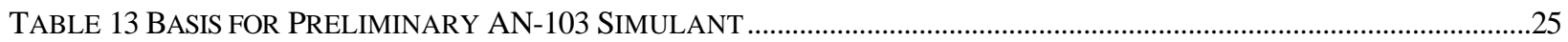

TABLE 14 PRELIMINARY AN-103 SIMULANT COMPOSITION.............................................................................................26

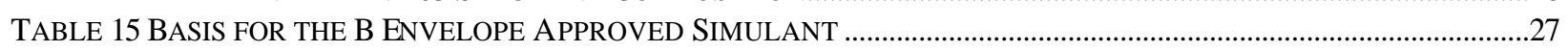

TABLE 16 COMPOSITION OF ENVELOPE B SIMULANT BASED ON TANK AZ-101 …………………………………..........28

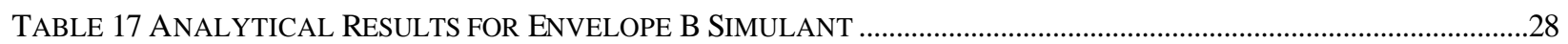

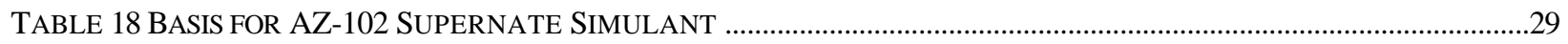

TABLE 19 COMPOSITION OF TANK AZ-102 SUPERNATE SIMULANT ……………………................................................30

TABLE 20 ANALYTICAL RESULTS FOR THE AZ-102 SUPERNATE SIMULANT ……………………………………….........32

TABLE 21 ANALYTICAL BASIS FOR APPROVED C SIMULANT BASED ON AN-107 ………………....................................34

TABLE 22 ORGANIC BASIS FOR APPROVED C SIMULANT FROM AN-107 .......................................................................35

TABLE 23 APPROVED C SIMULANT BASED ON TANK AN-107 SUPERNATE ………………………….............................36

TABLE 24 INORGANIC ANALYTICAL RESULTS FOR AN-107 SIMULANT ………………………………...........................37

TABLE 25 ORGANIC ANALYTICAL RESULTS FOR AN-107 SIMULANT ………………........................................................38

TABLE 26 AN-107 SIMULANT DENSITY AND WEIGHT PERCENT SOLIDS............................................................................39

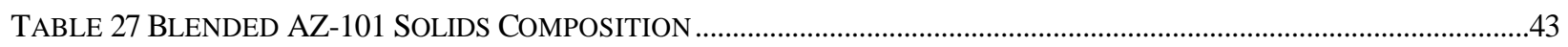

TABLE 28 SLUDGE PARTICLE SIZE COMPARISONS....................................................................................................

TABLE 29 BASIS FOR ENVELOPE A ENTRAINED SOLIDS FROM AN-105 SUPERNATE .......................................................4

TABLE 30 ENVELOPE A ENTRAINED SOLIDS FORMULATION BASED ON TANK AN-105 …………….............................49

TABLE 31 CALCULATED BASIS FOR THE AN-107 ENTRAINED SOLIDS..............................................................................50

TABLE 32 AN-107 UNWASHED ENTRAINED SOLIDS FORMULATION.............................................................................51

TABLE 33 ANALYTICAL BASIS FOR C-106 CAUSTIC LEACHATE SIMULANT ………….....................................................52

TABLE 34 C-106 CAUSTIC LEACHATE SIMULANT COMPOSITION ……………………………………….........................52

TABLE 35 ANALYTICAL RESULTS FOR SIMULATED C-106 CAUSTIC LEACHATE .............................................................53

TABLE 36 BASIS FOR A AZ-102 CAUSTIC LEACHATE SIMULANT …………………………………..............................54

TABLE 37 AZ-102 CAUSTIC LEACHATE SIMULANT COMPOSITION.................................................................................54

TABLE 38 ANALYTICAL RESULTS FOR AZ-102 CAUSTIC LEACHATE SIMULANT ……………………………………......55

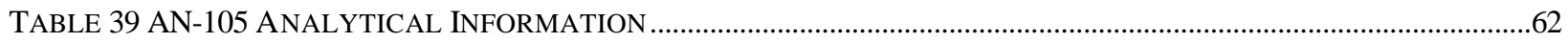

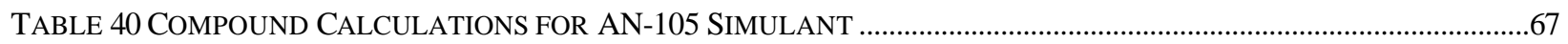

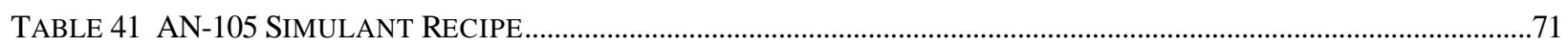

TABLE 42 BEST BASIS INVENTORY FOR TANK 241-AZ-101 USED IN ENVELOPE B SIMULANT ........................................74

TABLE 43 HYDROXIDE AND CARBONATE BASIS FOR B ENVELOPE SIMULANT ................................................................78

TABLE 44 CALCULATED “ANALYTICAL” DATA FOR ENVELOPE B SIMULANT ………………………………………….....79

TABLE 45 COMPOUND CALCULATIONS FOR ENVELOPE B SIMULANT …………….........................................................83

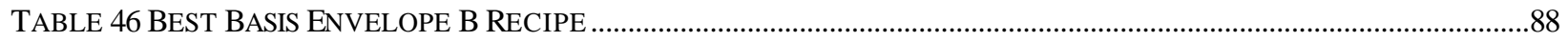

TABLE 47 TANK 241-AN-107 SUPERNATE COMPOSITION ……………………………………………………….............91 
Hanford Waste Simulants Created to Support Research and SRT-RPP-2000-00017

Development on the River Protection Project - Waste Treatment Plant

Revision (Date): $0(02 / 22 / 2001)$

Page: vi of 139

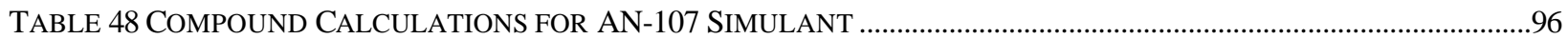

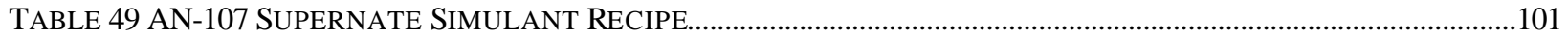

TABLE 50 SOLIDS COMPOSITION FOR TANK AZ-101 CORE \#1_..............................................................................................105

TABLE 51 SOLIDS COMPOSITION FOR TANK AZ-101 CORE \#2 ………………..........................................................111

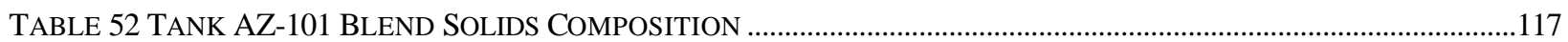

TABLE 53 COMPOUND CALCULATIONS FOR AZ-101 SIMULATED SLUDGE …………………………………………….....124

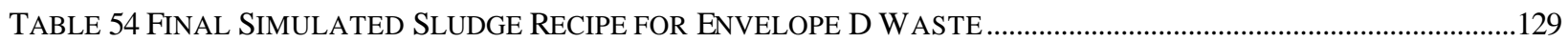

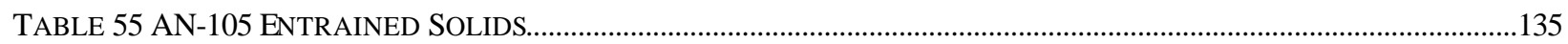

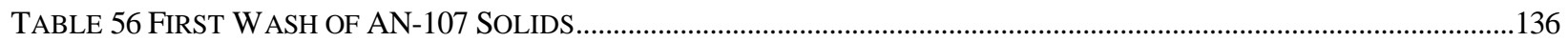

TABLE 57 SECOND W ASH OF SOLIDS FROM TANK AN-107 ………………………………………...............................138

TABLE 58 THIRD WASH OF SOLIDS FROM TANK AN-107 ......................................................................................140

TABLE 59 FOURTH W ASH OF SOLIDS FROM TANK AN-107 ......................................................................................143

TABLE 60 SUMMARY OF W ASHES FOR TANK AN-107 SOLIDS ..................................................................................145

TABLE 61 SOLIDS CALCULATION FOR UNWASHED ENTRAINED SOLIDS IN TANK AN-107..........................................147

TABLE 62 RECIPE FOR UNWASHED ENTRAINED SOLIDS FROM TANK AN-107 ...............................................................149 


\section{LIST OF FIGURES}

FIGURE 1 AN-105 SIMULANT DENSITY AS A FUNCTION OF THE NA CONCENTRATION 14

FIGURE 2 AN-105 SiMUlANT WEIGHT PERCENT SOLIDS (ANHYDROUS) AS A FUNCTION OF NA MOLARITY ...........15 FIGURE 3 SCANNING ELECTRON MICROSCOPE - ENERGY DISPERSIVE SPECTRA OF SOLIDS FROM AN-104 SIMULANT

FIGURE 4 X-RAY DIFFRACTION ANALYSIS OF SOLIDS FROM AN-104 SIMULANT ........................................................22

FIGURE 5 ENVELOPE C SIMULANT DENSITY AS A FUNCTION OF NA CONCENTRATION.............................................40

FIGURE 6 AN-107 Simulant WEIGHT \% SOLIDS (ANHYDROUS) AS A FUNCTION OF THE NA CONCENTRATION .....41

FIGURE 7 PARTICLE SIZE ANALYSIS FOR BLENDED AZ-101/AZ-102 SLUDGE .........................................................45

FIGURE 8 RHEOLOGY OF AZ-101 SLUDGE COMPARED TO THE AZ-101/AZ-102 BLEND SIMULANT ............................46 


\subsection{Executive Summary}

The development of nonradioactive waste simulants to support the River Protection Project -Waste Treatment Plant (RPP-WTP) bench and pilot-scale testing is crucial to the design of the facility. The report documents the simulants developed to support the SRTC programs and the strategies used to produce the simulants. The approved simulants for waste envelopes A, B, and C and the basis for their recipes is included. Additional simulants including sludge simulants, simulants of entrained solids, and simulants to support pretreatment mixing studies are discussed.

At the direction of RPP-WTP, the waste simulants were based upon specific waste characterization samples and did not involve averaging over multiple samples from multiple tanks, collected and analyzed at different times. This decision was made by the RPP-WTP team because most of the available sample analysis data is for grab samples for the Hanford site waste tanks. Grab samples are usually obtained from a single location within the tank waste and these samples may not represent the tank contents as a whole. An additional source of characterization information for Hanford site tank waste is the best basis inventory (BBI) for tank wastes. The BBI inventory is based on multiple, tank sampling events, waste processing information, and process chemistry knowledge. However, the BBI inventory did not list separate compositions for the liquid and solid phases present in each tank and therefore the BBI inventory could not be used effectively to prepare simulants under this task. The advantages and challenges of this approach are discussed along with recommendations for specific analyses that could improve the waste simulants.

The envelope A simulant that was developed as a part of this study and approved by the customer is based on the whole-tank composite analysis for waste stored in tank 241-AN-105. Additional envelope A simulants prepared or calculated include simulants of whole-tank composite compositions for wastes stored in tanks 241-AW-101, 241-AN-104, 241-AN-103 and a composite-dilution-based simulant of 241-AN-105. The envelope B simulant that was approved by the customer was based on the Best Basis Inventory (adjusted for liquid fraction only) for Tank 241-AZ-101, since no analysis of the present, tank liquid fraction was available in 1999. An additional B envelope simulant that was developed is based on the liquid fraction of waste in tank 241-AZ-102. The approved envelope C simulant is based on the liquid fraction of waste in tank 241-AN-107. Entrained solids simulants were created for envelopes $\mathrm{A}$ and $\mathrm{C}$ based upon analysis of the suspended solids in the waste stored in tanks 241-AN-105 and 241-AN-107 respectively.

The envelope D simulant was developed based upon tank 241-AZ-101 sludge that had not been caustic washed to reduce the aluminum level. Unlike the supernate simulants which assume that the supernate phase is homogeneous, the sludge simulant is based upon multiple samples and therefore make use of averaging. The AZ-101 sludge simulant is based on averaging two separate core samples due to the heterogeneous nature of the settled sludge. 
The formulation and testing of Hanford waste simulants to support development of the RPP-WTP was conducted in accordance with the quality assurance requirements of 10-CFR830.120 as implemented in the Savannah River Site quality assurance plan (BNF-003-98-0008). ${ }^{29}$

\subsection{Introduction and Background}

The River Protection Project -Waste Treatment Plant (RPP-WTP) will process the radioactive wastes currently stored in the single and double-shell tanks (SST and DST) at the Department of Energy Hanford site to produce suitable waste forms for long term storage. As part of the research and development on the processes planned for the waste treatment plant, nonradioactive simulants will be required for much of the testing. This report documents the simulants developed to support the Savannah River Technology Center programs in support of the RPP-WTP. The research described in this report was conducted under task plan BNF-003-98-011, rev 0. ${ }^{1}$ Additional simulants described in this report were also developed under task plan BNF-003-98-0079A. ${ }^{2}$

The RPP-WTP will vitrify both high-level wastes (HLW) and low activity wastes (LAW) using separate vitrification systems. The pretreatment processes include ultrafiltration using crossflow filter technology,

${ }^{90} \mathrm{Sr}$ and transuranic (TRU) removal by precipitation (Sr/TRU process), ${ }^{137} \mathrm{Cs}$ and ${ }^{99} \mathrm{Tc}$ removal by ion exchange, evaporation, HLW sludge washing/leaching, and waste and glass former blending. Development of these processes requires testing for lab through pilot scale test with nonradioactive simulants and lab-scale tests with the actual radioactive wastes. Therefore, development of simulants that duplicate the waste chemistry and, in some cases, the physical properties is required to support the overall program.

To aid in planning and designing the RPP-WTP, the waste to be processed was categorized as being part of four different waste envelopes: Envelope A, Envelope B, Envelope C and Envelope D. Each envelope, as it relates to the actual tank waste identified as candidate feed to the RPP-WTP, is described below. The request for proposals for design and construction of the RPP-WTP describes a much broader composition range for Envelopes A, B, C and D wastes. However for this task, simulants were prepared based on actual tank waste compositions that comply with the broader definition of the waste envelopes.

Envelope A - Also known as Double Shell Slurry Feed and Double-Shell Slurry. The waste was generated by evaporating the low organic content, waste supernates stored in single shell tanks and the supernate produced by the Hanford B plant. Envelope A can be generally characterized as an alkaline $\left(\left[\mathrm{OH}^{-}\right\}>1\right.$ Molar), high sodium (>8 Molar) supernate. The envelope contains ${ }^{137} \mathrm{Cs}$ and ${ }^{99} \mathrm{Tc}$ at concentrations that require removal prior to LAW vitrification. Sr/TRU removal is not required for this waste. The majority of the LAW supernate to be vitrified in the initial phase of the RPP-WTP will be envelope A. The Hanford tanks that have been classified as envelope A include 241AW-101, 241-AN-103, 241-AN-104, 241-AN-105 and 241-AP-105. 
Envelope B - Sometimes referred to as the supernate phase from Neutralized Current Acid Waste (NCAW). The envelope contains higher 137Cs concentrations than envelope A. The LAW glass specifications will require 137Cs and 99Tc removal. $\mathrm{Sr} / \mathrm{TRU}$ removal is not required for this waste. The envelope B is expected to be high in glass limiting constituents such as sulfate, phosphate, and halides. Only a small part of the LAW waste to be vitrified in the initial phase is envelope B. The tanks with supernate in the envelope are 241-AZ-101 and 241-AZ-102.

Envelope $\mathrm{C}$ - Also known as Complex Concentrate. The $\mathrm{C}$ waste was produced from evaporation of wastes derived from high organic content single-shell tank waste and waste generated during the $\mathrm{Cs} / \mathrm{Sr}$ separation and encapsulation process conducted at the Hanford B plant. The waste is characterized by the high organic carbon content due to the presence of organic complexing agents and their decomposition products. Due to the complexing agents, the concentration of ${ }^{90} \mathrm{Sr}$ and TRU will require removal using the Sr/TRU precipitation and filtration process. Removal of ${ }^{137} \mathrm{Cs}$ and ${ }^{99} \mathrm{Tc}$ by ion exchange will also be required. The tanks within the C envelope are 241-AN-102 and 241-AN-107.

Envelope D - Envelope D is composed of insoluble compounds referred to as sludge, primarily insoluble transition metal hydroxides with most of the long half-life radionuclides, slurried with the supernate from the same tank. For example, the slurry from tank 241-AZ-101 would be composed of the B envelope supernate and the D envelope sludge. As such, the tank could be described as a B/D tank. Similarly, there could by $\mathrm{A} / \mathrm{D}$ and $\mathrm{C} / \mathrm{D}$ tanks. The $\mathrm{D}$ envelope waste will require washing using crossflow filtration and possibly caustic leaching to meet glass specifications. Tanks with solids that are in the D envelope include 241-AZ-101, 241-AZ-102, 241-AY101 (planned mixture of tank 241-C-104 sludge and tank 241-AY-101 sludge), and 241-AY-102 (contains mixture of tank 241-C-106 sludge and tank 241-AY-102 sludge).

There are four basic kinds of waste simulants. These are (1) supernates, (2) sludges, (3) entrained solids, and (4) miscellaneous simulants that represent intermediate process streams. Each of these types of simulant can represent portions of each of the waste envelopes. For example, A, B, and C waste envelopes are all supernates but with differing compositions and each can have a different composition of entrained solids. Sludge simulants such as the D envelope material can represent washed or caustic leached sludge depending on the sludge composition. 


\subsection{Discussion}

\section{The Strategy Used in Waste Simulants}

The development of processes for safe and efficient disposal of radioactive waste requires detailed testing of proposed processes. However, the difficulty of handling radioactive waste makes detailed testing very difficult and expensive. The use of nonradioactive waste simulants eliminates most of the handling problems and allows less expensive detailed studies to proceed. Waste simulants are usually based upon the average composition for a type of waste determined by averaging over multiple samples collected at various times. The advantage of averaging is that a bad result will not seriously bias the simulant and that the impact of spatial distribution within the waste tank can be minimized. The disadvantage of averaging is that the amount of time-dependent waste components such as hydroxide, carbonate, nitrate and nitrite can be seriously under or over represented.

The waste simulants described in this report were not based upon averaging waste compositions. Instead, at the direction of the customer, waste simulants were based upon specific waste samples that were as well characterized as possible. The resulting simulant can represent a specific tank and can be traced back to a specific sample and sample analysis. Using this approach, the time-dependent waste compounds will be correctly simulated. The disadvantage of this approach is that a bad analysis can seriously impact the waste simulant. Therefore, reviewing the quality and reasonableness of the analysis is important to the application of the data. The waste simulant will only be as good or complete, as the analysis is good or complete. The application that the simulant will be used for must also be considered. The simulants described in this report were developed to support the pretreatment process planned for the RPP-WTP. The strategy used for the supernate simulants, entrained solids simulants and sludge simulants will be separately discussed.

\section{Supernate Simulants}

Supernate simulants must represent the aqueous phase of the waste present within the Hanford waste tanks. Since many of these supernates are at saturation as indicated by the presence of floating and settled crystallized salts (tank 241-AN-105 and others), production of the simulant will be bounded by the solubility of the various salts present. ${ }^{3}$ The steps required in creating the supernate simulant are:

1. Calculate the carbonate concentration from the measured total inorganic carbon (TIC) value. The TIC measurement is obtained by measuring the carbon dioxide released upon treating a sample with acid and therefore directly measures the carbonate concentration. 
2. If sulfate and/or phosphate measurements by ion chromatography are not available, calculate sulfate from sulfur and phosphate from phosphorus.

3. Calculate the borate concentration from the boron value and the metasilicate concentration from the silicon value.

4. Convert the chromium concentration to chromate and add as sodium chromate.

5. Calculate the charge balance between anions and cations. If the charge balance is extremely unbalanced (> 30\%), it may be better to find a more complete analysis of a different sample from the same tank.

6. Adjust either the hydroxide/carbonate or the sodium concentration to obtain the required balance. Usually the best choice is to raise or lower the free hydroxide content. Adjusting the hydroxide value is based upon the difficulty of accurately measuring the free hydroxide level. Depending on the other anions present, titration methods can suffer from interference from aluminate, carbonate, organic anions, and phosphate anions. If TIC has not been measured, the carbonate concentration can also be used to assist in charge balancing since carbonate is expected to be present in all of the supernates.

7. Determine if the transition metals plus aluminum content is low enough to permit the use of the metal nitrate, which are generally very soluble, as the source for the metal ion. For example, in envelope A waste the aluminum content would place too much nitrate in the supernate if the aluminum is added as the nitrate.

8. If required, calculate the aluminum as aluminum trihydroxide with an appropriate amount of sodium hydroxide to convert the compound to sodium aluminate.

9. If cesium and strontium concentrations are available from a spectroscopy method, add them as the nitrate salts. If the only concentration values available are for the radionuclides, ${ }^{137} \mathrm{Cs}$ and ${ }^{90} \mathrm{Sr}$, use the specific activity to calculate a mass concentration. Then adjust the cesium concentration to reflect that ${ }^{137} \mathrm{Cs}$ is $1 / 4$ to $1 / 3$ of the total cesium based upon expected fission product yields and ${ }^{90} \mathrm{Sr}$ is typically $1 / 10$ of the total strontium based upon prior experience with strontium isotopics from caustic-neutralized wastes.

10. Since all of the isotopes of technetium are radioactive, a substitute for technetium (rhenium) can be used if needed. Convert the ${ }^{99} \mathrm{Tc}$ value to a molar concentration using the specific activity and then convert to sodium perrhenate (assuming pertechnetate is the primary ${ }^{99} \mathrm{Tc}$ species).

11. Calculate all of the measured anions as sodium salts except boron, which can be added as boric acid. 
12. Create the recipe paying close attention to the sequence of compound addition to prevent unwanted destruction of some of the acid-reactive anions such as carbonate and nitrite. The initial test solution should be made up in a volumetric flask to insure that the proper volume of simulant is produced.

13. The sequence of addition used in this study was to mix the acidic compounds such as the transition metal nitrates together and dissolve in water. Of particular concern are compounds such as ferric nitrate or ferric chloride, which must be complexed before addition to the basic mixture. Combining the acidic metals with the complexing agents at this step assures that the metal will be soluble after the caustic is added. The complexing agents can be added as the free acids (adjusting the sodium hydroxide addition appropriately) or as the sodium salts.

14. In a separate container, mix the strong base with the aluminum species to generate the aluminate anion. The aluminum species chosen must be of known aluminum content. For example, Aluminum trihydroxide or Aluminum nitrate with known water contents can be used. Sodium aluminate can also be used if the precise aluminum content is known, however, the water content in the commercial forms of sodium aluminate usually varies. Next, dissolve the other nonreactive salts in the caustic mixture.

15. Blend the acidic and basic solutions together to produce an alkaline solution. The solution at this point must be alkaline to prevent destruction of two of the remaining anions that will be added in step 16.

16. Add the residual sodium nitrate and the reactive salts, sodium carbonate and sodium nitrite to the alkaline solution. Continuous agitation may be necessary to completely dissolve the final salt additions. Heat may also be used to aid in the final dissolution. To some extent, this addition sequence mimics the process by which the waste was originally generated.

17. Finally, measure the density of the simulant solution for use in calculating the water additions for very large batches of simulant where preparation by a volumetric approach is not feasible.

The resulting simulant solution should be low in insoluble solids since it is designed to represent the supernate phase of the tank waste. A trace of insoluble solids can form due to trace contaminants in the reagent chemicals used in preparation. The choice of the reagents can be critical to preparation of a good simulant. Particular attention must be placed on purity and the water of hydration, which is common with many of the metal salts. If excessive insoluble solids are observed, additional focus must be placed on the possible need for trace levels of complexing agents (e.g., EDTA, gluconate, etc.). Matching the measured total organic carbon value (TOC) was not a goal of the above procedure. The more complete the organic analysis is, the better the match with the TOC can be. However, artificially increasing the concentration of a measured organic species to aid in matching the TOC can introduce spurious chemical properties and was therefore not undertaken in this study. 


\section{Entrained Solids Simulants}

The entrained solid simulant is used for pilot studies of the crossflow filtration processes of the RPPWTP. The simulant should duplicate the chemical composition and the physical properties of the actual entrained solids where possible. Because of the filtration studies, particle size is an important parameter for the simulant. The customer requested that the simulant be based upon specific solids characterization data, which should include particle size information. If particle size information is not available, the most conservative approach will be to use particles in the range that will be a challenge to the filtration system, less than 10 micron. The wastes requiring an entrained solids simulant will generally be the $\mathrm{A}$ and $\mathrm{C}$ envelopes. The $\mathrm{B}$ envelope waste is expected to have entrained solids that are sludge particles from envelope D. Therefore, a separate B entrained solids simulant was not developed. The steps required in creating the entrained solids simulant are:

1. Calculate the moles of each element or anion detected in the washed solids for that waste.

2. If a TOC measurement is available on the solids, convert the TOC value from moles of carbon to moles of oxalate. This assumes that the insoluble form of organic carbon is oxalate. Research on the solubility of organic complexing agents indicated that oxalate is the major insoluble organic species in Hanford waste. ${ }^{4}$

3. The transition metals and aluminum and silicon are calculated as the insoluble oxides.

4. Alkali metals and alkaline earth's are calculated as the most insoluble salts possible based on the measured anions. For example, if oxalate is present use sodium oxalate or calcium oxalate. Other candidate compounds could be calcium phosphate or calcium sulfate depending on the measured anions present.

5. Calculate the mass of each compound, the total mass of the suggested compounds and the percent the compound makes up of the simulant solids and of the actual solids from the waste. If the percent of the actual solids is greater than $80 \%$, the simulant will probably match, within analytical error, the actual waste solid from an analysis, point of view. If the percent of the actual is less than 80 , alternate insoluble species such as different oxidation states for the transition metals, should be considered.

6. Since the simulant is produced by mixing solids together, the particle size of the solids should be specified to match the measured particle size range of the actual entrained solids. This will insure that the simulant properly tests the filtration process.

As with all simulants, the simulant can only be as good as the analytical data it is generated from and the simulant results should always be confirmed by actual waste tests. 


\section{Envelope D Simulants}

The envelope $\mathrm{D}$ waste is primarily insoluble transition metal oxides and hydroxides that were generated by addition of sodium hydroxide to nitric acid process waste streams. As such, the best way to generate a simulant, which has the correct chemical and physical properties, is to simulate the original waste stream and then the waste storage process. Unfortunately, the parameters of temperature, time and radiation are not easily simulated in a rapid fashion. Therefore, no effort was made to duplicate these parameters. Rapid mixing and shearing can be used to insure that the precipitated metal oxides and hydroxides produce fine particles instead of large gelatinous flocks. Unlike the supernate simulants, the envelope $\mathrm{D}$ simulant can be produced from multiple source compounds as long as sufficient washing is included to remove the unwanted associated anion. The process used to generate the envelope D simulant uses the following steps:

1. Calculate the grams/liter of each metal and anion present in the washed D waste. If the waste simulant is to represent caustic leached envelope D waste either start with an analysis of the waste after caustic leaching or assume a leaching factor for aluminum and reduce the aluminum content by that factor.

2. Calculate the mass of each transition metal to be added based upon the use of nitrate salts. Aluminum should be added as the oxide (preferably boehmite, $\mathrm{AlOOH}$ ), boron as boric acid, molybdenum as either sodium or potassium molybdate, and silicon and titanium as the oxide. The anions will be added as sodium salts.

3. Calculate the amount of potassium permanganate and manganous nitrate necessary to produce the required hydrated manganese dioxide.

4. Generate the hydrated $\mathrm{MnO}_{2}$ solids by mixing potassium permanganate and manganous nitrate according to the following stoichiometry:

$$
3 \mathrm{Mn}\left(\mathrm{NO}_{3}\right)_{2}+2 \mathrm{KMnO}_{4}+2 \mathrm{H}_{2} \mathrm{O} \longrightarrow 2 \mathrm{KNO}_{3}+5 \mathrm{MnO}_{2}+4 \mathrm{HNO}_{3}
$$

5. Add to the hydrated $\mathrm{MnO}_{2}$ solids the transition metal nitrates that form precipitates in caustic solutions, for example $\mathrm{Fe}, \mathrm{Ni}, \mathrm{Cr}$, etc. The amphoteric metals such as aluminum and other compounds such as silica and titania will not be added until step 10 .

6. Precipitate the metals with sodium hydroxide until a stable $\mathrm{pH}>10$ is achieved.

7. Add a sodium carbonate solution to convert some of the more soluble hydroxides into less soluble carbonates. Allow at least 18 hours (overnight or over a weekend) for the solids to settle. 
8. Decant the supernate and wash the precipitated solids. Note that the final wash should be with inhibited water, 0.01 molar in sodium hydroxide and 0.01 molar in sodium nitrite.

9. The washing should continue until the nitrate concentration in the supernate is less than 1000 $\mathrm{mg} / \mathrm{liter}$.

10. Add the additional insoluble compounds $\left(\mathrm{Al}_{2} \mathrm{O}_{3}, \mathrm{SiO}_{2}\right.$, and $\left.\mathrm{TiO} 2\right)$ in a controlled particle size form to assist in duplicating the actual waste particles size. Mix thoroughly and then add the soluble salts that remain followed by additional mixing.

If desired, additional heat treatment can be used to represent some of the waste thermal history. Additional shearing may also be useful in reducing the simulated sludge particle size. As with all simulants, the simulant can only be as good as the analytical data it is generated from and the simulant results should always be confirmed by actual waste tests.

Appendix $\mathrm{G}$ lists the analytical methods used to measure the concentration of species in simulant test recipes.

\section{Envelope A Simulants}

The following simulants were calculated and/or prepared to support SRTC research: Approved A Envelope simulant based upon AN-105 supernate, an AN-105 whole tank composite simulant, an AW-101 simulant, an AN-104 whole tank composite simulant, and a preliminary simulant based upon AN-103. The source of each of these simulants and the specific issues in the preparation of these simulants will be described individually.

\section{Approved A Simulant - AN-105 Simulant}

The waste retrieval scenario that the envelope A simulant was based on was the supernate from tank 241-AN-105 was decanted from the solids within the waste tank without any effort to dissolve the solids or dilute the waste. The AN-105 simulant produced to support SRTC testing of filtration, ion exchange and evaporation was based primarily on the initial privatization sample from AN-105 with some supplementary results from another recent AN-105 sample. ${ }^{5,6}$ The initial privatization sample was spiked with potassium chromate and cesium hydroxide for use as an envelope B sample even though AN-105 is clearly envelope A material. The measured TOC value of 3.6 grams/Liter carbon suggested that measurable levels of organic compounds such as formate, oxalate, acetate and glycolate should be present in the waste. However, organic speciation data was not available for the 241-AN-105 waste at the time the simulant was being prepared. Since a very similar waste, tank AW-101, was also sampled and analyzed during the initial privatization studies, the values for these organic compounds were taken from that waste analysis. ${ }^{7}$ The cesium concentration was based upon the ${ }^{137} \mathrm{Cs}$ concentration of $1.79 \mathrm{E}+07$ becquerels/mL making up $1 / 3$ of the total cesium. The composition basis used for the AN105 simulant is listed in Table 1. 


\section{Table 1 Approved Envelope A Simulant Based on Tank 241-AN-105}

\begin{tabular}{|c|c|c|}
\hline Component & Moles/Liter & mg/Liter \\
\hline Aluminum & $1.47 \mathrm{E}+00$ & 39700 \\
\hline Ammonium & $6.65 \mathrm{E}-03$ & 120 \\
\hline Boron & $4.72 \mathrm{E}-03$ & 51 \\
\hline Cadmium & $2.94 \mathrm{E}-05$ & 3 \\
\hline Calcium & $9.98 \mathrm{E}-04$ & 40 \\
\hline Carbonate & 2.09E-01 & 12540 \\
\hline Cesium & $1.22 \mathrm{E}-04$ & 16 \\
\hline Chromium & $2.60 \mathrm{E}-02$ & 1350 \\
\hline Hydroxide & $3.42 \mathrm{E}+00$ & 58100 \\
\hline Lead & $2.56 \mathrm{E}-04$ & 53 \\
\hline Magnesium & $2.22 \mathrm{E}-04$ & 5 \\
\hline Molybdenum & $8.55 \mathrm{E}-04$ & 82 \\
\hline Potassium & $1.92 \mathrm{E}-01$ & 7500 \\
\hline Selenium & $1.25 \mathrm{E}-05$ & 1 \\
\hline Silicon & $7.51 \mathrm{E}-03$ & 211 \\
\hline Silver & $1.51 \mathrm{E}-04$ & 16 \\
\hline Sodium & $1.07 \mathrm{E}+01$ & 246000 \\
\hline Tin & $1.83 \mathrm{E}-04$ & 22 \\
\hline Zinc & $1.54 \mathrm{E}-04$ & 10 \\
\hline TIC & 2.09E-01 & 2510 \\
\hline TOC & $2.99 \mathrm{E}-01$ & 3590 \\
\hline Chloride & $2.56 \mathrm{E}-01$ & 9090 \\
\hline Fluoride & $1.00 \mathrm{E}-02$ & 190 \\
\hline Formate & $6.40 \mathrm{E}-02$ & 2880 \\
\hline Nitrate & $2.66 \mathrm{E}+00$ & 165000 \\
\hline Nitrite & $2.41 \mathrm{E}+00$ & 111000 \\
\hline Oxalate & $6.93 \mathrm{E}-03$ & 610 \\
\hline Phosphate & $6.00 \mathrm{E}-03$ & 570 \\
\hline Sulfate & 8.03E-03 & 771 \\
\hline Acetate & $3.51 \mathrm{E}-02$ & 2070 \\
\hline Glycolate & $1.53 \mathrm{E}-02$ & 1150 \\
\hline
\end{tabular}

The charge balance for the simulant initially had 0.55 moles/Liter of excess negative ions, which indicates a closure of about $95 \%$. The excess negative charge was balanced by allowing the sodium to 
increase by 0.55 moles/Liter from the measured 10.1 moles/Liter to 10.7 moles/Liter. Appendix A details the computations performed to transform Table 1 data into the compounds listed in Table 2.

Table 2 AN-105 Simulant Composition

\begin{tabular}{|c|c|c|}
\hline Compounds & Formula & Grams/Liter \\
\hline Boric Acid & $\mathrm{H}_{3} \mathrm{BO}_{3}$ & 0.292 \\
\hline Cadmium Nitrate & $\mathrm{Cd}\left(\mathrm{NO}_{3}\right)_{2} \bullet 4 \mathrm{H}_{2} \mathrm{O}$ & 0.009 \\
\hline Calcium Nitrate & $\mathrm{Ca}\left(\mathrm{NO}_{3}\right)_{2} \bullet 4 \mathrm{H}_{2} \mathrm{O}$ & 0.236 \\
\hline Cesium Nitrate & $\mathrm{CsNO}_{3}$ & 0.024 \\
\hline Lead nitrate & $\mathrm{Pb}\left(\mathrm{NO}_{3}\right)_{2}$ & 0.085 \\
\hline Magnesium Nitrate & $\mathrm{Mg}\left(\mathrm{NO}_{3}\right)_{2} \bullet 6 \mathrm{H}_{2} \mathrm{O}$ & 0.057 \\
\hline Potassium Nitrate & $\mathrm{KNO}_{3}$ & 19.221 \\
\hline Silver Nitrate & $\mathrm{AgNO}_{3}$ & 0.026 \\
\hline Zinc Nitrate & $\mathrm{Zn}\left(\mathrm{NO}_{3}\right)_{2} \bullet 6 \mathrm{H}_{2} \mathrm{O}$ & 0.046 \\
\hline Glycolic Acid & $\mathrm{HOCH}_{2} \mathrm{COOH}, 70 \mathrm{wt} \%$ & 1.665 \\
\hline Sodium Chloride & $\mathrm{NaCl}$ & 14.984 \\
\hline Sodium Fluoride & $\mathrm{NaF}$ & 0.420 \\
\hline Sodium Chromate & $\mathrm{Na}_{2} \mathrm{CrO}_{4}$ & 4.205 \\
\hline Sodium Sulfate & $\mathrm{Na}_{2} \mathrm{SO}_{4}$ & 1.140 \\
\hline Potassium Molybdate & $\mathrm{K}_{2} \mathrm{MoO}_{4}$ & 0.204 \\
\hline Ammonium Acetate & $\mathrm{CH}_{3} \mathrm{COONH}_{4}$ & 0.513 \\
\hline Aluminum Trihydroxide & $\mathrm{Al}(\mathrm{OH})_{3}$ & 114.77 \\
\hline Sodium Hydroxide & $\mathrm{NaOH}$ & 196.68 \\
\hline Selenium dioxide & $\mathrm{SeO}_{2}$ & 0.001 \\
\hline Sodium meta-silicate & $\mathrm{Na}_{2} \mathrm{SiO}_{3} \bullet 9 \mathrm{H}_{2} \mathrm{O}$ & 2.135 \\
\hline Sodium Acetate & $\mathrm{NaCH}_{3} \mathrm{COO} \bullet 3 \mathrm{H}_{2} \mathrm{O}$ & 3.865 \\
\hline Sodium Formate & HCOONa & 4.351 \\
\hline Sodium Oxalate & $\mathrm{Na}_{2} \mathrm{C}_{2} \mathrm{O}_{4}$ & 0.929 \\
\hline Sodium Phosphate & $\mathrm{Na}_{3} \mathrm{PO}_{4} \bullet 12 \mathrm{H}_{2} \mathrm{O}$ & 2.281 \\
\hline Sodium Carbonate & $\mathrm{Na}_{2} \mathrm{CO}_{3}$ & 22.149 \\
\hline Sodium Nitrate & $\mathrm{NaNO}_{3}$ & 209.70 \\
\hline Sodium Nitrite & $\mathrm{NaNO}_{2}$ & 166.48 \\
\hline Water & $\mathrm{H}_{2} \mathrm{O}$ & 669.37 \\
\hline
\end{tabular}

Testing the AN-105 simulant gave a density of $1.44 \mathrm{~g} / \mathrm{mL}$ at $20 \mathrm{C}$. The simulant produced just a small amount of solids but did require several hours of mixing to dissolve the added compounds. On days when the temperature was cooler, more solids would crystallize out. When the temperature rose the solids would redissolve suggesting that the solution is saturated in some of the waste components and is correctly reflecting the AN-105 conditions (floating crystallized salts). ${ }^{3}$ Simulant preparation was performed at 20-22 C. Table 3 gives an analysis of some of the waste components in a test batch of the AN-105 simulant. 
Table 3 Analytical results on AN-105 Simulant

\begin{tabular}{|c|c|c|c|c|}
\hline Component & Units & Found & Planned & \% of Target \\
\hline $\mathrm{Al}$ & $\mathrm{mg} / \mathrm{Liter}$ & 35700 & 39700 & 90 \\
\hline $\mathrm{B}$ & $\mathrm{mg} / \mathrm{Liter}$ & 48 & 51 & 94 \\
\hline $\mathrm{Ca}$ & $\mathrm{mg} / \mathrm{Liter}$ & $<1$ & 40 & $<2$ \\
\hline $\mathrm{Cd}$ & $\mathrm{mg} / \mathrm{Liter}$ & 10 & 10 & 100 \\
\hline $\mathrm{Cr}$ & $\mathrm{mg} / \mathrm{Liter}$ & 1450 & 1350 & 107 \\
\hline $\mathrm{K}$ & $\mathrm{mg} / \mathrm{Liter}$ & 8380 & 7500 & 112 \\
\hline $\mathrm{Mg}$ & $\mathrm{mg} / \mathrm{Liter}$ & $<1$ & 5 & $<20$ \\
\hline $\mathrm{Mo}$ & $\mathrm{mg} / \mathrm{Liter}$ & 89 & 82 & 109 \\
\hline $\mathrm{Na}$ & $\mathrm{mg} / \mathrm{Liter}$ & 257000 & 246000 & 104 \\
\hline $\mathrm{Pb}$ & $\mathrm{mg} / \mathrm{Liter}$ & 46 & 53 & 87 \\
\hline $\mathrm{Si}$ & $\mathrm{mg} / \mathrm{Liter}$ & 129 & 211 & 61 \\
\hline $\mathrm{Zn}$ & $\mathrm{mg} / \mathrm{Liter}$ & 19 & 12 & 158 \\
\hline $\mathrm{Chloride}$ & $\mathrm{mg} / \mathrm{Liter}$ & 9200 & 9090 & 101 \\
\hline Fluoride & $\mathrm{mg} / \mathrm{Liter}$ & $<100$ & 190 & $<50$ \\
\hline Formate & $\mathrm{mg} / \mathrm{Liter}$ & 2980 & 2880 & 103 \\
\hline Nitrate & $\mathrm{mg} / \mathrm{Liter}$ & 172000 & 165000 & 104 \\
\hline Nitrite & $\mathrm{mg} / \mathrm{Liter}$ & 120000 & 111000 & 108 \\
\hline Oxalate & $\mathrm{mg} / \mathrm{Liter}$ & $<100$ & 610 & $<16$ \\
\hline Phosphate & $\mathrm{mg} / \mathrm{Liter}$ & $<100$ & 570 & $<18$ \\
\hline Sulfate & $\mathrm{mg} / \mathrm{Liter}$ & 950 & 825 & 115 \\
\hline
\end{tabular}

The results are typical for attempts at measuring a saturated solution, note the high sodium nitrate and nitrite levels measured. Low level of phosphate and fluoride may indicate some formation of the insoluble fluorophosphate double salt, which has been observed in other simulant waste supernates. ${ }^{8}$ It is also interesting to note that the alkaline earth metals $(\mathrm{Ca}$ and $\mathrm{Mg})$ which form relatively insoluble salts with oxalate, phosphate and fluoride are lower than targeted as are the appropriate anions. The low silicon result could also be due to formation of an aluminosilicate. Other A simulant formulations also had difficulty with lower than planned phosphate concentrations, however, at lower sodium concentrations a higher concentration of phosphate was achieved (see AW-101 and AN-104 simulants).

Relatively large volumes of simulant are required for the pilot ion exchange and crossflow filtration studies. To assist in producing the diluted supernate simulant, a series of diluted AN-105 simulants were prepared volumetrically so that the density of the diluted simulant could be measured. Table 4 lists the measured densities and the weight percent solids calculated for these dilutions as a function of the sodium ion concentration. The weight percent solids value represents the solids with no waters of hydration and is a theoretical (computed) value. This should be used as a guide since measuring the weight percent solids by oven or microwave drying may lead to varying levels of dehydration and possibly some decomposition and therefore a different value. 
Table 4 AN-105 Simulant Density and Percent Solids

\begin{tabular}{|c|c|c|}
\hline Na Concentration, Molar & Density, g/mL & Wt \% Anhydrous Solids \\
\hline 2.0 & 1.111 & 12.89 \\
\hline 4.5 & 1.205 & 26.63 \\
\hline 5.01 & 1.228 & 29.06 \\
\hline 5.49 & 1.248 & 31.37 \\
\hline 6.02 & 1.265 & 33.91 \\
\hline 8.0 & 1.35 & 42.26 \\
\hline 10.7 & 1.44 & 52.72 \\
\hline
\end{tabular}

The densities listed in table 4 were measured at 20 to $22 \mathrm{C}$ (ambient lab temperatures). The sodium concentration versus the density can be fit empirically to the following simple equation to allow predictions of densities (Y, gm/mL) for different sodium concentrations ( $\mathrm{X}$, Na molarity) when the supernate is diluted:

$$
\mathrm{Y}^{2}=1.007+0.10029 \mathrm{X}
$$

Besides the measured values, at infinite dilution, the sodium concentration would be zero and the density would be that of water, $0.997 \mathrm{~g} / \mathrm{mL}$ This assumption was also included in the data set that was fitted. Figure 1 display the fitted curve versus the measured and assumed data point. 
AN-105 Supernate Simulant Fitted Equation $\mathrm{Y}^{2}=1.007+0.10029 \mathrm{X}$

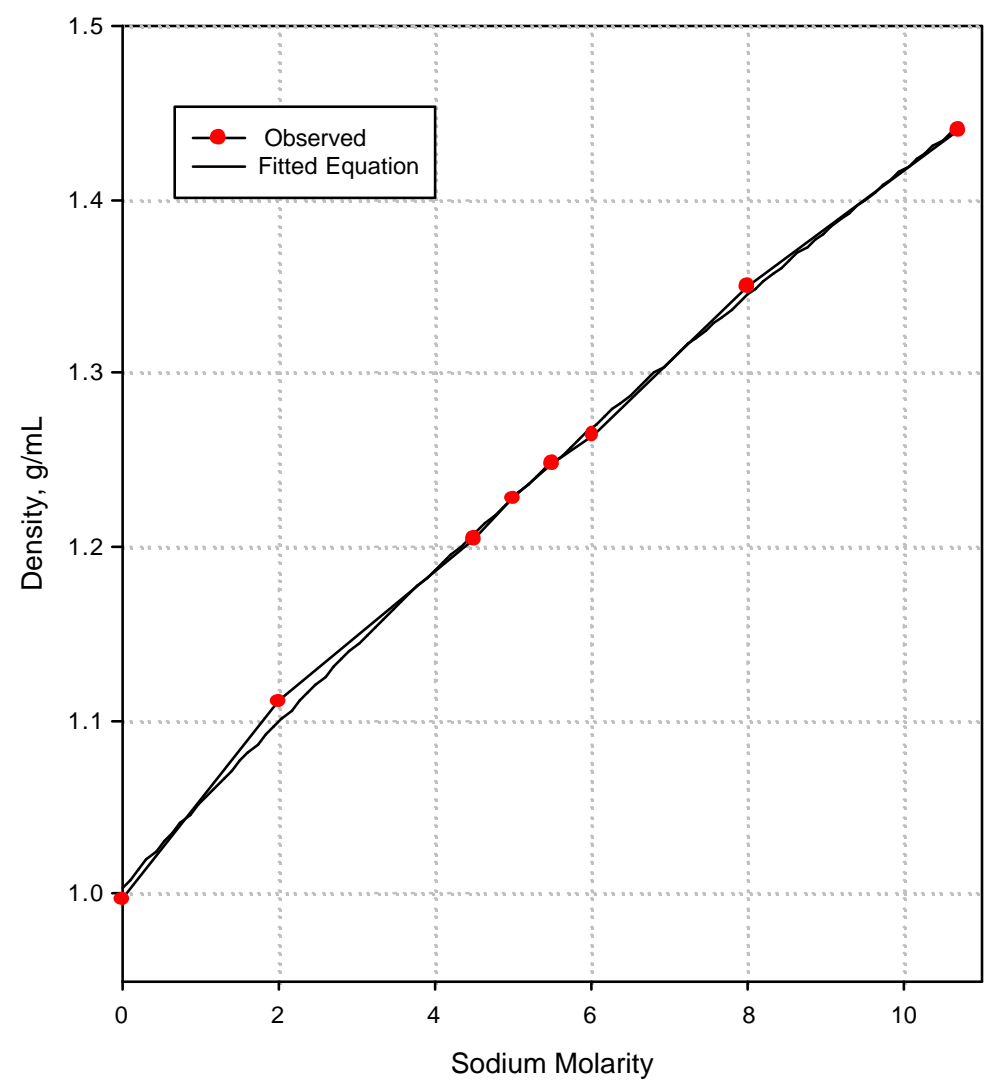

Figure 1 AN-105 Simulant Density as a Function of the Na Concentration

The $\mathrm{r}^{2}$ value for the fit is 0.998 . The relationship can be used for this specific ratio of compounds across the range measured but should not be extended to other simulant recipes.

The weight percent solids (anhydrous) can also plotted and fitted to a curve. Note that the assumption is made that at 0.0 Molar $\mathrm{Na}$ (X, Na molarity), the weight percent solid ( Y, wt \%) is also 0.0. Figure 2 demonstrates that the power law curve,

$$
\mathrm{Y}=7.917 \mathrm{X}^{0.803}
$$


provides a good fit to the results, $\mathrm{r}^{2}$ is 0.999 .

AN-105 Supernate Simulant Fitted Equation $\mathrm{y}=7.917 \mathrm{X}^{0.803}$

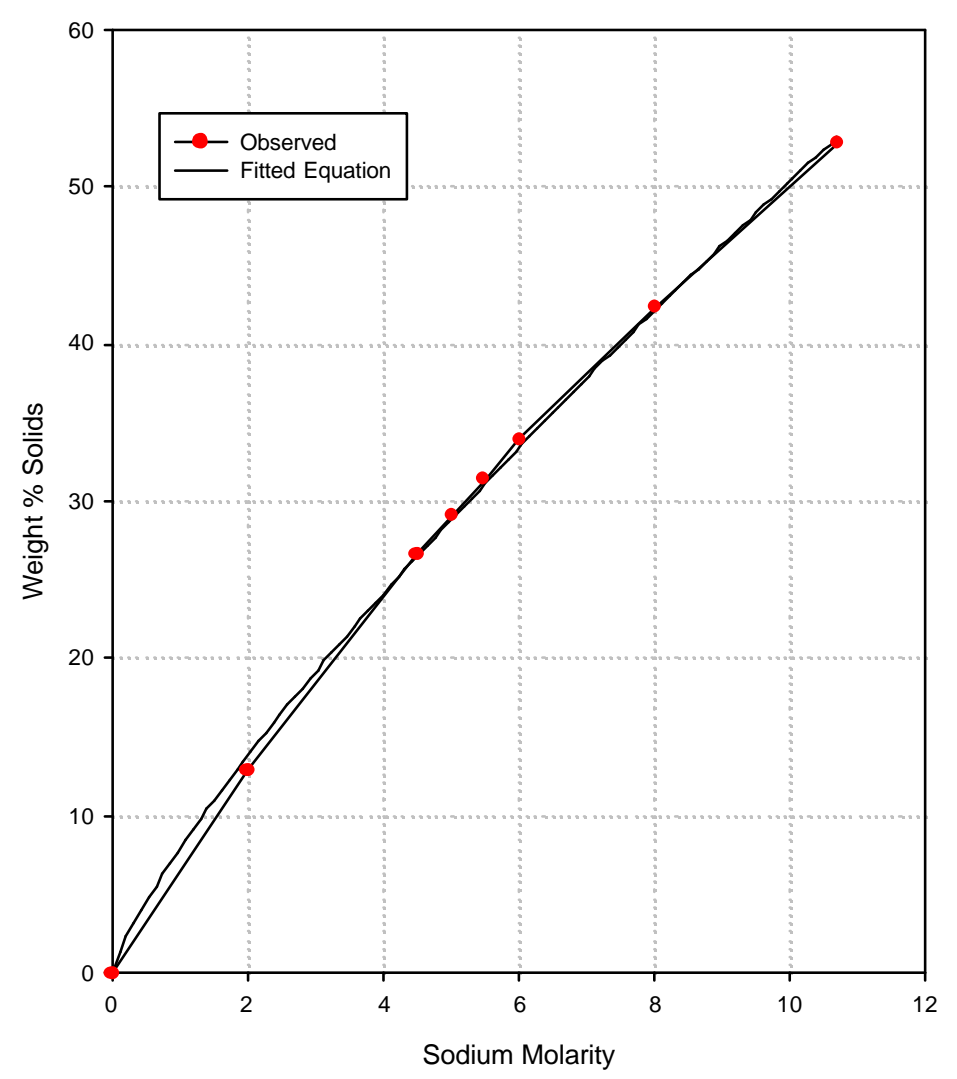

Figure 2 AN-105 Simulant Weight Percent Solids (Anhydrous) as a Function of Na Molarity

As mentioned previously, the relationship given by equation (2) is only for the composition specified for the approved AN-105 simulant. Actual measurements of weight percent solids can differ from this curve due to waters of hydration or due to actual compound decomposition. As such the curve should be used as a guide. For example, equation 2 or figure 2 can be used to estimate the Na concentration after dilution based upon a total solids measurement. 


\section{AN-105 Whole Tank Composite Simulant}

Another simulant based upon tank 241-AN-105 was created to support the mixing of process heels and process solutions study. ${ }^{9}$ The retrieval scenario that the simulant was based upon was one in which the entire tank is mixed and then water is added to achieve $50 \%$ dilution by volume. ${ }^{10}$ This scenario produces a supernate which is more of a whole tank composite and contains relatively higher levels of the less soluble anions due to dissolution. Table 5 gives the analytical basis of the simulant.

Table 5 AN-105 Fifty Volume \% Dilution Whole Tank Composite Simulant

\begin{tabular}{|c|c|c|}
\hline Component & Moles/Liter & mg/Liter \\
\hline Aluminum & $7.84 \mathrm{E}-01$ & 21150 \\
\hline Boron & $3.05 \mathrm{E}-03$ & 33 \\
\hline Carbonate & $4.51 \mathrm{E}-01$ & 27054 \\
\hline Chromium & $1.64 \mathrm{E}-02$ & 854 \\
\hline Hydroxide & $2.03 \mathrm{E}+00$ & 34600 \\
\hline Molybdenum & $5.42 \mathrm{E}-04$ & 52 \\
\hline Potassium & $1.28 \mathrm{E}-01$ & 5010 \\
\hline Silicon & $3.60 \mathrm{E}-03$ & 101 \\
\hline Sodium & $7.24 \mathrm{E}+00$ & 166500 \\
\hline TIC & $4.51 \mathrm{E}-01$ & 5415 \\
\hline TOC & $1.72 \mathrm{E}-01$ & 2070 \\
\hline Chloride & $1.65 \mathrm{E}-01$ & 5840 \\
\hline Fluoride & $2.38 \mathrm{E}-02$ & 453 \\
\hline Nitrate & $2.17 \mathrm{E}+00$ & 134500 \\
\hline Nitrite & $1.73 \mathrm{E}+00$ & 79800 \\
\hline Oxalate & $6.24 \mathrm{E}-03$ & 549 \\
\hline Phosphate & $1.37 \mathrm{E}-02$ & 1305 \\
\hline Sulfate & $3.85 \mathrm{E}-02$ & 3695 \\
\hline
\end{tabular}

The planned density for the simulant was 1.32 grams $/ \mathrm{mL}$. Equation (1) predicts a density of 1.316 despite the relative change in some of the concentrations. The charge balance showed excess negative ions by 0.62 moles/Liter. The charge balance for the planned simulant was obtained by reducing the hydroxide concentration by 0.62 moles/Liter. Note the significantly higher levels of carbonate, fluoride, phosphate and sulfate despite the solution being more dilute in sodium, nitrate and nitrite. The higher levels of the less soluble anions demonstrate dissolution of some of the crystallized salts in the waste due to the planned retrieval method.

The planned simulant composition based upon the reported density of 1.32 grams/mL is shown in Table 6. 


\section{Table 6 Planned AN-105 Fifty Volume \% Dilution} Whole Tank Composite Simulant Composition

\begin{tabular}{|c|c|c|}
\hline Compounds & Formula & Grams/Liter \\
\hline Boric Acid & $\mathrm{H}_{3} \mathrm{BO}_{3}$ & 0.189 \\
\hline Potassium Nitrate & $\mathrm{KNO}_{3}$ & 12.845 \\
\hline Sodium Chloride & $\mathrm{NaCl}$ & 9.627 \\
\hline Sodium Fluoride & $\mathrm{NaF}$ & 1.000 \\
\hline Sodium Chromate & $\mathrm{Na}_{2} \mathrm{CrO}_{4}$ & 2.659 \\
\hline Sodium Sulfate & $\mathrm{Na}_{2} \mathrm{SO}_{4}$ & 5.464 \\
\hline Potassium Molybdate & $\mathrm{K}_{2} \mathrm{MoO}_{4}$ & 0.129 \\
\hline Aluminum Trihydroxide & $\mathrm{Al}(\mathrm{OH})_{3}$ & 61.142 \\
\hline Sodium Hydroxide & $\mathrm{NaOH}_{3}$ & 113.098 \\
\hline Sodium meta-silicate & $\mathrm{Na}_{2} \mathrm{SiO}_{3} \bullet 9 \mathrm{H}_{2} \mathrm{O}$ & 1.022 \\
\hline Sodium Oxalate & $\mathrm{Na}_{2} \mathrm{C}_{2} \mathrm{O}_{4}$ & 0.836 \\
\hline Sodium Phosphate & $\mathrm{Na}_{3} \mathrm{PO}_{4} \bullet 12 \mathrm{H}_{2} \mathrm{O}$ & 5.223 \\
\hline Sodium Carbonate & $\mathrm{Na}_{2} \mathrm{CO}_{3}$ & 47.784 \\
\hline Sodium Nitrate & $\mathrm{NaNO}_{3}$ & 173.561 \\
\hline Sodium Nitrite & $\mathrm{NaNO}_{2}$ & 119.686 \\
\hline Water & $\mathrm{H}_{2} \mathrm{O}_{1}$ & 762.19 \\
\hline
\end{tabular}

A test solution of this simulant was not prepared since computation of a similar simulant representing the envelope A tank AN-104 indicated that the AN-104 simulant was more conservative for the mixing study planned (see the simulant described below).

\section{AN-104 Whole Tank Composite Simulant}

The AN-104 whole tank composite simulant is based upon a retrieval scenario in which the entire tank is mixed and then water is added to achieve $50 \%$ dilution by volume. ${ }^{11}$ The resulting supernate is 7.61 molar in sodium ion and contains substantially higher levels of phosphate, sulfate and carbonate due to dissolution of salts within the solids present in AN-104. The simulant was created to support the mixing of process heels and process solutions study. ${ }^{9}$ Just as in the AN-105 simulant previously described, the AN-104 simulant is a whole tank composite based simulant due to the dissolution of crystallized salts. Due to the addition of water in the presence of the crystallized salts in AN-104, the supernate is likely saturated with carbonates, phosphates and sulfates salts. Table 7 gives the analytical basis for the simulant. 


\section{Table 7 AN-104 Fifty Volume \% Dilution Whole Tank Composite Simulant}

\begin{tabular}{|c|c|c|}
\hline Component & Moles/Liter & mg/Liter \\
\hline Aluminum & $8.60 \mathrm{E}-01$ & 23200 \\
\hline Boron & $3.05 \mathrm{E}-03$ & 33 \\
\hline Carbonate & $6.24 \mathrm{E}-01$ & 37421 \\
\hline Chromium & $4.77 \mathrm{E}-03$ & 248 \\
\hline Hydroxide & $2.48 \mathrm{E}+00$ & 42100 \\
\hline Molybdenum & $5.21 \mathrm{E}-04$ & 50 \\
\hline Potassium & $1.28 \mathrm{E}-01$ & 5010 \\
\hline Silver & $1.21 \mathrm{E}-04$ & 13 \\
\hline Silicon & $5.45 \mathrm{E}-03$ & 153 \\
\hline Sodium & $7.61 \mathrm{E}+00$ & 175000 \\
\hline TIC & $6.24 \mathrm{E}-01$ & 7490 \\
\hline TOC & $1.56 \mathrm{E}-01$ & 1870 \\
\hline Chloride & $1.44 \mathrm{E}-01$ & 5100 \\
\hline Fluoride & $2.66 \mathrm{E}-02$ & 506 \\
\hline Nitrate & $1.65 \mathrm{E}+00$ & 102000 \\
\hline Nitrite & $1.40 \mathrm{E}+00$ & 64500 \\
\hline Oxalate & $6.24 \mathrm{E}-03$ & 549 \\
\hline Phosphate & $3.09 \mathrm{E}-02$ & 2930 \\
\hline Sulfate & $7.41 \mathrm{E}-02$ & 7120 \\
\hline & & \\
\hline & & \\
\hline
\end{tabular}

The oxalate concentration used in the $\mathrm{AN}-104$ simulant was taken from the AN-105 simulant previously described due to the AN-104 measurement being reported as a less than value $(<1000$ $\mathrm{mg} /$ Liter) while oxalate was expected to be present. The TOC value of 1.87 grams/liter also suggested that some oxalate should be added. The charge balance from the analytical data had an excess level of negative ions by 0.37 moles/liter out of 7.72 moles/liter (balance of $95 \%$ ). Therefore, the hydroxide concentration was reduced by 0.37 moles/liter. The AN-104 simulant composition based upon the reported density of 1.31 grams $/ \mathrm{mL}$ is shown in Table 8 . 
Table 8 AN-104 Fifty Volume \% Dilution Whole Tank Composite Simulant Composition

\begin{tabular}{|c|c|c|}
\hline Compounds & Formula & Grams/Liter \\
\hline Boric Acid & $\mathrm{H}_{3} \mathrm{BO}_{3}$ & 0.189 \\
\hline Potassium Nitrate & $\mathrm{KNO}_{3}$ & 10.367 \\
\hline Silver Nitrate & $\mathrm{AgNO}_{3}$ & 0.020 \\
\hline Sodium Chloride & $\mathrm{NaCl}$ & 8.407 \\
\hline Sodium Fluoride & $\mathrm{NaF}$ & 1.118 \\
\hline Sodium Chromate & $\mathrm{Na}_{2} \mathrm{CrO}_{4}$ & 0.773 \\
\hline Sodium Sulfate & $\mathrm{Na}_{2} \mathrm{SO}_{4}$ & 10.528 \\
\hline Potassium Molybdate & $\mathrm{K}_{2} \mathrm{MoO}_{4}$ & 0.124 \\
\hline Aluminum Trihydroxide & $\mathrm{Al}(\mathrm{OH})_{3}$ & 67.068 \\
\hline Sodium Hydroxide & $\mathrm{NaOH}_{2}$ & 119.053 \\
\hline Sodium meta-silicate & $\mathrm{Na}_{2} \mathrm{SiO}_{3} \bullet 9 \mathrm{H}_{2} \mathrm{O}$ & 1.548 \\
\hline Sodium Oxalate & $\mathrm{Na}_{2} \mathrm{C}_{2} \mathrm{O}_{4}$ & 0.836 \\
\hline Sodium Phosphate & $\mathrm{Na}_{3} \mathrm{PO}_{4} \bullet 12 \mathrm{H}_{2} \mathrm{O}$ & 11.727 \\
\hline Sodium Carbonate & $\mathrm{Na}_{2} \mathrm{CO}_{3}$ & 66.095 \\
\hline Sodium Nitrate & $\mathrm{NaNO}_{3}$ & 131.086 \\
\hline Sodium Nitrite & $\mathrm{NaNO}_{2}$ & 96.738 \\
\hline Water & $\mathrm{H}_{2} \mathrm{O}$ & 776.77 \\
\hline
\end{tabular}

The measured density of the simulant was 1.333 grams $/ \mathrm{mL}$ at ambient lab temperatures (20 to $22 \mathrm{C}$ ). The weight percent total solids using the microwave oven technique was $39.55 \%$. A day or two after the simulant was prepared, the lab temperature dropped to $8 \mathrm{C}$ and white solids were observed to have crystallized from the simulant. Upon heating to $45 \mathrm{C}$ the solids dissolved. The residual fine solids were filtered and collected. The supernate was submitted for analysis and the solids were submitted for characterization by x-ray diffraction and by scanning electron microscopy with energy dispersive analysis. The analytical results for the supernate are shown in Table 9 while the solids characterization is shown in figures 3 and 4. 
Table 9 Analytical Results on AN-104 Simulant

\begin{tabular}{|c|c|c|c|c|}
\hline Component & Units & Found & Planned & \% of Target \\
\hline $\mathrm{Al}$ & $\mathrm{mg} / \mathrm{Liter}$ & 17650 & 23200 & 76 \\
\hline $\mathrm{B}$ & $\mathrm{mg} / \mathrm{Liter}$ & 32 & 33 & 97 \\
\hline $\mathrm{Ag}$ & $\mathrm{mg} / \mathrm{Liter}$ & 1.4 & 13 & 11 \\
\hline $\mathrm{Cr}$ & $\mathrm{mg} / \mathrm{Liter}$ & 212 & 248 & 85 \\
\hline $\mathrm{K}$ & $\mathrm{mg} / \mathrm{Liter}$ & 3960 & 4050 & 98 \\
\hline $\mathrm{Na}$ & $\mathrm{mg} / \mathrm{Liter}$ & 182760 & 175000 & 104 \\
\hline $\mathrm{Si}$ & $\mathrm{mg} / \mathrm{Liter}$ & 144 & 153 & 94 \\
\hline $\mathrm{Mo}$ & $\mathrm{mg} / \mathrm{Liter}$ & 49 & 50 & 98 \\
\hline $\mathrm{Chloride}$ & $\mathrm{mg} / \mathrm{Liter}$ & 5031 & 5100 & 99 \\
\hline Fluoride & $\mathrm{mg} / \mathrm{Liter}$ & 103 & 506 & 20 \\
\hline Nitrate & $\mathrm{mg} / \mathrm{Liter}$ & 99490 & 102000 & 98 \\
\hline Nitrite & $\mathrm{mg} / \mathrm{Liter}$ & 64040 & 64500 & 99 \\
\hline Oxalate & $\mathrm{mg} / \mathrm{Liter}$ & 250 & 549 & 46 \\
\hline Phosphate & $\mathrm{mg} / \mathrm{Liter}$ & 2017 & 2930 & 69 \\
\hline Sulfate & $\mathrm{mg} / \mathrm{Liter}$ & 7072 & 7120 & 99 \\
\hline TIC & $\mathrm{mg} / \mathrm{Liter}$ & 13070 & 7490 & 175 \\
\hline TOC & $\mathrm{mg} / \mathrm{Liter}$ & 779 & 150 & 520 \\
\hline
\end{tabular}




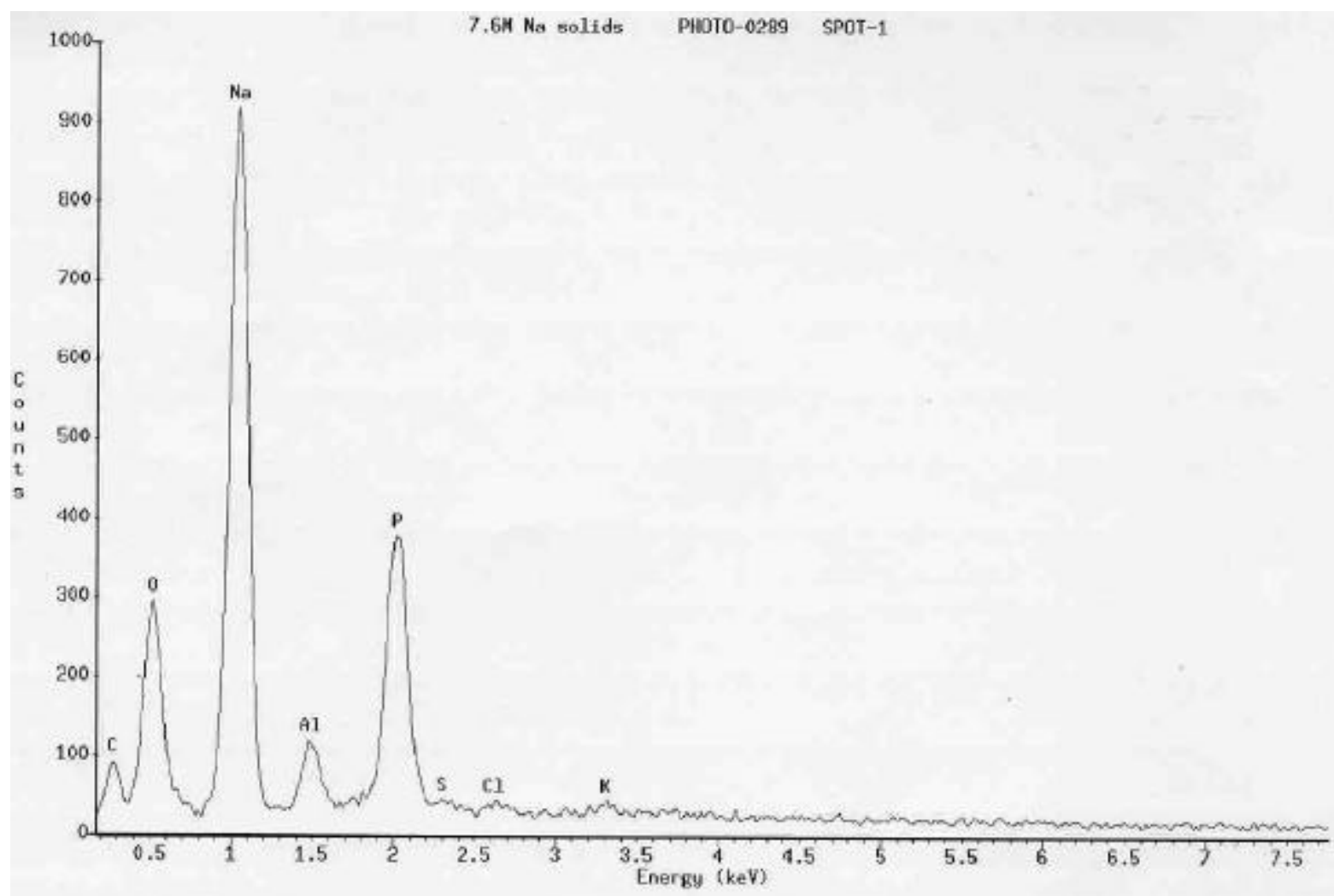

Figure 3 Scanning Electron Microscope - Energy Dispersive Spectra of Solids from AN-104 Simulant 


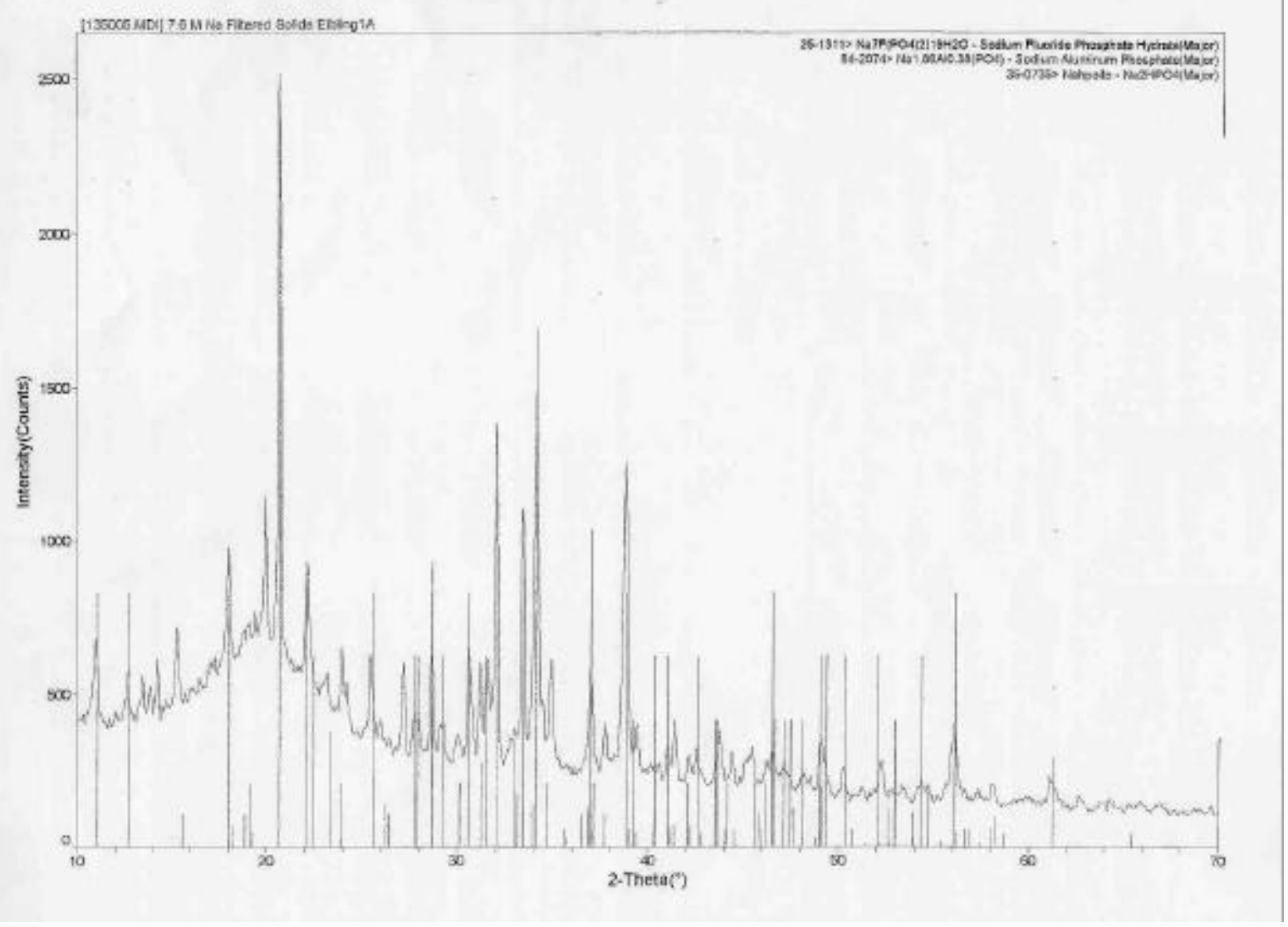

\section{Figure 4 X-ray Diffraction Analysis of Solids from AN-104 simulant}

The low results shown for fluoride and phosphate are confirmed by the presence of fluorophosphate double salt detected by XRD in figure 4. The low result for silver may be due to photoreduction of the silver ion since dark particles were observed in the simulant shortly after makeup. The low aluminum result was traced to the aluminum trihydroxide that was used. The aluminum source was only $80 \%$ pure due to absorbed water, therefore, the aluminum measured was actually very close to the amount added. 
The high TIC result was probably due to carbon dioxide absorption, leading to the production of carbonate.

\section{AW-101 Simulant}

The AW-101 simulant was based on supernate samples that were obtained from five equally spaced elevations in the liquid phase of waste stored in Hanford tank 241-AW-101 as diluted with de-ionized water to a sodium concentration of 6.46 molar. $^{12}$ The waste simulant is a high hydroxide, high aluminate, envelope A tank. The simulant was created to support the mixing of process heels and process solutions study. ${ }^{9}$ The analytical basis for the AW-101 simulant is given in table 10 .

Table 10 Basis for AW-101 Simulant

\begin{tabular}{|c|c|c|}
\hline Component & Moles/Liter & mg/Liter \\
\hline Aluminum & $6.06 \mathrm{E}-01$ & 16350 \\
\hline Carbonate & 1.79E-01 & 10767 \\
\hline Cesium & $8.13 \mathrm{E}-05$ & 11 \\
\hline Chromium & $1.08 \mathrm{E}-03$ & 56 \\
\hline Hydroxide & $3.05 \mathrm{E}+00$ & 51872 \\
\hline Iron & $8.42 \mathrm{E}-05$ & 5 \\
\hline Lead & $1.98 \mathrm{E}-04$ & 41 \\
\hline Nickel & $8.18 \mathrm{E}-05$ & 5 \\
\hline Potassium & $5.88 \mathrm{E}-01$ & 23000 \\
\hline Silicon & 4.63E-03 & 130 \\
\hline Sodium & $6.46 \mathrm{E}+00$ & 148500 \\
\hline Zinc & $2.14 \mathrm{E}-04$ & 14 \\
\hline Zirconium & $8.33 \mathrm{E}-05$ & 8 \\
\hline TIC & $1.79 \mathrm{E}-01$ & 2155 \\
\hline TOC & $1.30 \mathrm{E}-01$ & 1560 \\
\hline Chloride & $9.31 \mathrm{E}-02$ & 3300 \\
\hline Fluoride & 4.37E-02 & 830 \\
\hline Nitrate & $1.98 \mathrm{E}+00$ & 123000 \\
\hline Nitrite & $1.36 \mathrm{E}+00$ & 62750 \\
\hline Phosphate & $2.05 \mathrm{E}-02$ & 1950 \\
\hline Sulfate & $1.93 \mathrm{E}-02$ & 1850 \\
\hline
\end{tabular}

The charge balance for the analytical information has an excess of negative ions by 0.56 moles/Liter, which is a $92 \%$ balance. The hydroxide was reduced by 0.56 moles/Liter so as not to increase the sodium concentration. The analytical information does not show any organic species despite the measured TOC. The AW-101 simulant composition based upon the reported density of 1.32 grams $/ \mathrm{mL}$ is shown in Table 11. 
Table 11 Diluted AW-101 Simulant Composition

\begin{tabular}{|c|c|c|}
\hline Compounds & Formula & Grams/Liter \\
\hline Cesium Nitrate & $\mathrm{CsNO}_{3}$ & 0.016 \\
\hline Ferric Nitrate & $\mathrm{Fe}\left(\mathrm{NO}_{3}\right)_{3} \bullet 9 \mathrm{H}_{2} \mathrm{O}$ & 0.034 \\
\hline Lead Nitrate & $\mathrm{Pb}_{2}\left(\mathrm{NO}_{3}\right)_{2}$ & 0.066 \\
\hline Nickel Nitrate & $\mathrm{Ni}\left(\mathrm{NO}_{3}\right)_{2} \bullet 6 \mathrm{H}_{2} \mathrm{O}$ & 0.024 \\
\hline Zinc Nitrate & $\mathrm{Zn}\left(\mathrm{NO}_{3}\right)_{2} \bullet 6 \mathrm{H}_{2} \mathrm{O}$ & 0.064 \\
\hline Zirconyl Nitrate & $\mathrm{ZrO}\left(\mathrm{NO}_{3}\right)_{2} \bullet \mathrm{xH}_{2} \mathrm{O}, \mathrm{x} 1$ & 0.021 \\
\hline Potassium Nitrate & $\mathrm{KNO}_{3}$ & 59.473 \\
\hline Sodium Chloride & $\mathrm{NaCl}_{2}$ & 5.440 \\
\hline Sodium Fluoride & $\mathrm{NaF}$ & 1.834 \\
\hline Sodium Chromate & $\mathrm{Na}_{2} \mathrm{CrO}_{4}$ & 0.175 \\
\hline Sodium Sulfate & $\mathrm{Na}_{2} \mathrm{SO}_{4}$ & 2.736 \\
\hline Aluminum Trihydroxide & $\mathrm{Al}_{4}(\mathrm{OH})_{3}$ & 47.266 \\
\hline Sodium Hydroxide & $\mathrm{NaOH}_{2} \mathrm{Na}_{2}$ & 123.773 \\
\hline Sodium meta-silicate & $\mathrm{Na}_{2} \mathrm{SiO}_{3} \bullet \mathrm{H}_{2} \mathrm{O}$ & 1.315 \\
\hline Sodium Phosphate & $\mathrm{Na}_{3} \mathrm{PO}_{4} \bullet 12 \mathrm{H}_{2} \mathrm{O}$ & 7.805 \\
\hline Sodium Carbonate & $\mathrm{Na}_{2} \mathrm{CO}_{3}$ & 19.017 \\
\hline Sodium Nitrate & $\mathrm{NaNO}_{3}$ & 118.473 \\
\hline Sodium Nitrite & $\mathrm{NaNO}_{2}$ & 94.114 \\
\hline Water & $\mathrm{H}_{2} \mathrm{O}$ & 833.12 \\
\hline
\end{tabular}

The measured density of the simulant was 1.31 grams $/ \mathrm{mL}$. The weight percent solids based on microwave drying was $36.0 \%$. The analytical results for the simulant are shown in Table 12.

Table 12 Analytical Results for AW-101 Simulant

\begin{tabular}{|c|c|c|c|c|}
\hline Component & Units & Found & Planned & \% of Target \\
\hline $\mathrm{Al}$ & $\mathrm{mg} / \mathrm{Liter}$ & 12150 & 16350 & 74 \\
\hline $\mathrm{Cr}$ & $\mathrm{mg} / \mathrm{Liter}$ & 45 & 56 & 81 \\
\hline $\mathrm{Cs}$ & $\mathrm{mg} / \mathrm{Liter}$ & 11.8 & 11 & 107 \\
\hline $\mathrm{K}$ & $\mathrm{mg} / \mathrm{Liter}$ & 22730 & 23000 & 99 \\
\hline $\mathrm{Na}$ & $\mathrm{mg} / \mathrm{Liter}$ & 138670 & 148500 & 93 \\
\hline $\mathrm{Pb}$ & $\mathrm{mg} / \mathrm{Liter}$ & 28 & 41 & 68 \\
\hline $\mathrm{Si}$ & $\mathrm{mg} / \mathrm{Liter}$ & 125 & 130 & 96 \\
\hline $\mathrm{Zn}$ & $\mathrm{mg} / \mathrm{Liter}$ & 15 & 14 & 109 \\
\hline $\mathrm{Chloride}$ & $\mathrm{mg} / \mathrm{Liter}$ & 2570 & 3300 & 78 \\
\hline $\mathrm{Fluoride}$ & $\mathrm{mg} / \mathrm{Liter}$ & 112 & 830 & 13 \\
\hline Nitrate & $\mathrm{mg} / \mathrm{Liter}$ & 105344 & 123000 & 86 \\
\hline Nitrite & $\mathrm{mg} / \mathrm{Liter}$ & 59905 & 62750 & 95 \\
\hline Phosphate & $\mathrm{mg} / \mathrm{Liter}$ & 799 & 1950 & 41 \\
\hline Sulfate & $\mathrm{mg} / \mathrm{Liter}$ & 2403 & 1850 & 130 \\
\hline TIC & $\mathrm{mg} / \mathrm{Liter}$ & 9620 & 2155 & 446 \\
\hline TOC & $\mathrm{mg} / \mathrm{Liter}$ & $<200$ & & \\
\hline
\end{tabular}


The simulant generated solids over a week period which were filtered from the feed. The solids were not analyzed. However, it is reasonable to assume that species similar to what was detected in the AN104 simulant would form in the AW-101 simulant. The low levels of fluoride and phosphate confirm that the insoluble fluorophosphate salt has formed. The source material for aluminum is the reason the aluminum is below target (see $\mathrm{AN}-104$ simulant).

\section{Preliminary AN-103 Simulant}

A preliminary tank AN-103 supernate simulant was prepared to support ion exchange studies for the RPP-WTP. The simulant was based upon the analytical characterization of the actual AN-103 sample shipped to SRTC for characterization and active process studies. ${ }^{13}$ The Hanford site 222-S Analytical Laboratory prepared the AN-103 waste sample by mixing fractions of a core sample to represent a composite of the AN-103 tank contents. The as received supernate was assumed to be diluted by a factor of 2.276 to a diluted sodium concentration of 5.25 molar. Table 13 lists the basis for the AN103 supernate simulant.

Table 13 Basis for Preliminary AN-103 Simulant

\begin{tabular}{|c|c|c|}
\hline Component & Moles/Liter & mg/Liter \\
\hline Aluminum & $1.59 \mathrm{E}+00$ & 42870 \\
\hline Boron & $2.78 \mathrm{E}-03$ & 30 \\
\hline Cadmium & $1.16 \mathrm{E}-05$ & 1 \\
\hline Carbonate & $4.76 \mathrm{E}-01$ & 28578 \\
\hline Chromium & $3.27 \mathrm{E}-03$ & 170 \\
\hline Copper & $2.68 \mathrm{E}-05$ & 2 \\
\hline Hydroxide & $3.18 \mathrm{E}+00$ & 54150 \\
\hline Lead & $3.91 \mathrm{E}-04$ & 81 \\
\hline Molybdenum & $8.13 \mathrm{E}-04$ & 78 \\
\hline Nickel & $2.90 \mathrm{E}-05$ & 2 \\
\hline Potassium & $2.76 \mathrm{E}-01$ & 10790 \\
\hline Silicon & $1.02 \mathrm{E}-02$ & 286 \\
\hline Sodium & $1.19 \mathrm{E}+01$ & 274570 \\
\hline Silver & $9.27 \mathrm{E}-06$ & 1 \\
\hline Zirconium & $2.85 \mathrm{E}-05$ & 3 \\
\hline TIC & $4.76 \mathrm{E}-01$ & 5720 \\
\hline TOC & $7.13 \mathrm{E}-02$ & 856 \\
\hline Chloride & $1.40 \mathrm{E}-01$ & 4960 \\
\hline Fluoride & $1.93 \mathrm{E}-02$ & 367 \\
\hline Formate & $6.00 \mathrm{E}-02$ & 2700 \\
\hline Nitrate & $3.57 \mathrm{E}+00$ & 221650 \\
\hline Nitrite & $2.36 \mathrm{E}+00$ & 108600 \\
\hline Oxalate & $1.34 \mathrm{E}-02$ & 1180 \\
\hline Phosphate & $1.57 \mathrm{E}-02$ & 1490 \\
\hline Sulfate & $1.76 \mathrm{E}-02$ & 1690 \\
\hline
\end{tabular}

The assumption was made that everything would remain in solution at the undiluted concentration. The reality is that some of the species were insoluble in the as received sample and dissolved during dilution. 
Oxalate, for example, would not be expected to be soluble at the concentration shown in Table 13 when sodium is nearly 12 molar. The other species that might not be in solution include carbonate, phosphate, fluoride and sulfate. The charge balance for AN-103 had an excess of 0.194 moles/liter of cations (balance is $98 \%$ ). Th hydroxide level was increased by 0.194 moles/liter to create the final simulant. The AN-103 simulant composition is shown in Table 14 based upon a density of 1.49 grams $/ \mathrm{mL}$.

Table 14 Preliminary AN-103 Simulant Composition

\begin{tabular}{|c|c|c|}
\hline Compounds & Formula & Grams/Liter \\
\hline Boric Acid & $\mathrm{H}_{3} \mathrm{BO}_{3}$ & 0.172 \\
\hline Cadmium Nitrate & $\mathrm{Cd}\left(\mathrm{NO}_{3}\right)_{2} \bullet 4 \mathrm{H}_{2} \mathrm{O}$ & 0.004 \\
\hline Copper Nitrate & $\mathrm{Cu}\left(\mathrm{NO}_{3}\right)_{2} \bullet 2.5 \mathrm{H}_{2} \mathrm{O}$ & 0.006 \\
\hline Lead Nitrate & $\mathrm{Pb}\left(\mathrm{NO}_{3}\right)_{2}$ & 0.066 \\
\hline Nickel Nitrate & $\mathrm{Ni}\left(\mathrm{NO}_{3}\right)_{2} \bullet 6 \mathrm{H}_{2} \mathrm{O}$ & 0.008 \\
\hline Zirconyl Nitrate & $\mathrm{ZrO}\left(\mathrm{NO}_{3}\right)_{2} \bullet \mathrm{xH}_{2} \mathrm{O}, \mathrm{x} \sim 1$ & 0.007 \\
\hline Potassium Molybdate & $\mathrm{K}_{2} \mathrm{MoO}_{4}$ & 0.194 \\
\hline Potassium Nitrate & $\mathrm{KNO}_{3}$ & 27.736 \\
\hline Sodium Chloride & $\mathrm{NaCl}_{2}$ & 8.175 \\
\hline Sodium Fluoride & $\mathrm{NaF}_{2}$ & 0.811 \\
\hline Sodium Chromate & $\mathrm{Na}_{2} \mathrm{CrO}_{4}$ & 0.530 \\
\hline Sodium Sulfate & $\mathrm{Na}_{2} \mathrm{SO}_{4}$ & 2.499 \\
\hline Aluminum Trihydroxide & $\mathrm{Al}_{2}\left(\mathrm{OH}_{3}\right.$ & 123.93 \\
\hline Sodium Hydroxide & $\mathrm{NaOH}_{3}$ & 199.02 \\
\hline Sodium meta-silicate & $\mathrm{Na}_{2} \mathrm{SiO}_{3} \bullet 9 \mathrm{H}_{2} \mathrm{O}$ & 2.894 \\
\hline Sodium Phosphate & $\mathrm{Na}_{3} \mathrm{PO}_{4} \bullet 12 \mathrm{H}_{2} \mathrm{O}$ & 5.964 \\
\hline Sodium Formate & $\mathrm{NaHCOO}_{2}$ & 4.079 \\
\hline Sodium Oxalate & $\mathrm{Na}_{2} \mathrm{C}_{2} \mathrm{O}_{4}$ & 1.796 \\
\hline Sodium Carbonate & $\mathrm{Na}_{2} \mathrm{CO}_{3}$ & 50.476 \\
\hline Sodium Nitrate & $\mathrm{NaNO}_{3}$ & 280.415 \\
\hline Sodium Nitrite & $\mathrm{NaNO}_{2}$ & 162.881 \\
\hline Water & $\mathrm{H}_{2} \mathrm{O}$ & 613.30 \\
\hline
\end{tabular}

The AN-103 simulant will require additional testing if further work is planned requiring this simulant.

\section{Envelope B Simulants}

The following simulants were calculated and/or prepared to support SRTC research: Approved B Envelope simulant based upon AZ-101 supernate and an AZ-102 simulant. The source of each of these simulants and the specific issues in the preparation of these simulants will be described individually.

\section{Approved B Simulant - AZ-101 Best Basis Inventory Simulant}

Tank 241-AZ-101 was a NCAW receiver and the supernate in this tank has not been concentrated by processing through an evaporator. As an envelope B waste, the supernate contains higher ${ }^{137} \mathrm{Cs}$ 
concentrations than envelope A. The LAW glass specifications will require ${ }^{137} \mathrm{Cs}$ and ${ }^{99} \mathrm{Tc}$ removal. $\mathrm{Sr}$ /TRU removal is not required for this waste. The envelope B is expected to be high in glass limiting constituents such as sulfate. A simulant of envelope B is necessary to support ion exchange studies, evaporation and sulfate removal studies. [Note: Sulfate removal studies were conducted in calendar year 1999, but removal of sulfate from LAW solutions is no longer part of the reference flowsheet for treatment of Hanford site wastes.] A well-characterized sample of AZ-101 supernate was not available for creating a simulant. Therefore, the customer directed that the Best Basis Inventory of 10-1-1998 be used to develop a composition for the simulant. The Best Basis Inventory is a mass based inventory of the waste components.

The spreadsheets used to calculate the envelope B simulant composition and recipe are shown in Appendix B. The inventory information was converted from mass to concentration by using the reported density for AZ-101 supernate of 1.2 grams $/ \mathrm{mL} .{ }^{14}$ The supernate volume is $3.03 \mathrm{E}+06$ liters or $8.00 \mathrm{E}+05$ gallons. The inventory contains only a few of the major waste compounds and, therefore, the simulant will be a simple simulant, without many trace species. Table 15 specifies the analytical information the simulant is based upon.

Table 15 Basis for the B Envelope Approved Simulant

\begin{tabular}{|c|c|c|}
\hline Component & Moles/Liter & mg/Liter \\
\hline Aluminum & $3.95 \mathrm{E}-01$ & 10670 \\
\hline Ammonium & $1.84 \mathrm{E}-02$ & 313 \\
\hline Cesium & $2.81 \mathrm{E}-04$ & 37 \\
\hline Chromium & $1.40 \mathrm{E}-02$ & 730 \\
\hline Potassium & $1.18 \mathrm{E}-01$ & 4624 \\
\hline Sodium & $4.74 \mathrm{E}+00$ & 108990 \\
\hline Zirconium & $3.37 \mathrm{E}-05$ & 3.1 \\
\hline Chloride & $5.63 \mathrm{E}-03$ & 200 \\
\hline Fluoride & $9.54 \mathrm{E}-02$ & 1813 \\
\hline Nitrate & $1.22 \mathrm{E}+00$ & 75632 \\
\hline Nitrite & $1.41 \mathrm{E}+00$ & 65063 \\
\hline Phosphate & $1.58 \mathrm{E}-02$ & 1503 \\
\hline Sulfate & $1.84 \mathrm{E}-01$ & 17670 \\
\hline
\end{tabular}

The charge balance based upon the inventory is very poor with an excess of positive charge of 1.30 moles/Liter out of 4.78 moles/liter (balance of $72 \%$ ). The reason for the poor charge balance is the absence of a value for hydroxide and for carbonate. The ratio of carbonate and hydroxide to the sum of carbonate and hydroxide was fixed based upon a previously reported AZ-101 composition. ${ }^{15}$ This ratio was then applied to supply the 1.3 moles/Liter needed for charge balancing the simulant (for details see Table 43). Also missing from the inventory is any organic carbon containing species. Therefore, no organic species was included in the formulation. Note that oxalate or formate would have reduced the 
amount of both hydroxide and carbonate the formulation requires since they would have reduced the charge imbalance. Table 16 gives the composition of the Envelope B Simulant based upon the calculated hydroxide and carbonate results.

Table 16 Composition of Envelope B Simulant Based on Tank AZ-101

\begin{tabular}{|c|c|c|}
\hline Compounds & Formula & Grams/Liter \\
\hline Ammonium Nitrate & $\mathrm{NH}_{4} \mathrm{NO}_{3}$ & 1.470 \\
\hline Cesium Nitrate & $\mathrm{CsNO}_{3}$ & 0.055 \\
\hline Zirconyl Nitrate & $\mathrm{ZrO}\left(\mathrm{NO}_{3}\right)_{2} \bullet \mathrm{XH}_{2} \mathrm{O}, \mathrm{x} \sim 1$ & 0.008 \\
\hline Potassium Nitrate & $\mathrm{KNO}_{3}$ & 11.956 \\
\hline Sodium Chloride & $\mathrm{NaCl}$ & 0.329 \\
\hline Sodium Fluoride & $\mathrm{NaF}$ & 4.008 \\
\hline Sodium Chromate & $\mathrm{Na}_{2} \mathrm{CrO}_{4}$ & 2.274 \\
\hline Sodium Sulfate & $\mathrm{Na}_{2} \mathrm{SO}_{4}$ & 26.128 \\
\hline Aluminum Trihydroxide & $\mathrm{Al}(\mathrm{OH})_{3}$ & 30.839 \\
\hline Sodium Hydroxide & $\mathrm{NaOH}_{3}$ & 37.205 \\
\hline Sodium Phosphate & $\mathrm{Na}_{3} \mathrm{PO}_{4} \bullet 12 \mathrm{H}_{2} \mathrm{O}$ & 6.015 \\
\hline Sodium Carbonate & $\mathrm{Na}_{2} \mathrm{CO}_{3}$ & 40.757 \\
\hline Sodium Nitrate & $\mathrm{NaNO}_{3}$ & 92.027 \\
\hline Sodium Nitrite & $\mathrm{NaNO}_{2}$ & 97.583 \\
\hline Water & $\mathrm{H}_{2} \mathrm{O}$ & 845.93 \\
\hline
\end{tabular}

By comparison with some of the previous simulants, the Envelope B simulant is a simple simulant with a sodium concentration of 4.74 molar. Since the B simulant is already at low sodium concentration (compared to envelopes $\mathrm{A}$ and $\mathrm{C}$ ), dilutions of the $\mathrm{B}$ simulant were not made to determine the density. The RPP-WTP processes will probably not need to dilute the envelope B feed. Table 17 gives the analytical results for the approved B simulant after the simulant has equilibrated for more than thirty days.

Table 17 Analytical Results for Envelope B Simulant

\begin{tabular}{|c|c|c|c|c|}
\hline Component & Units & Found & Planned & \% of Target \\
\hline $\mathrm{Al}$ & $\mathrm{mg} / \mathrm{Liter}$ & 7752 & 10670 & 73 \\
\hline $\mathrm{Cr}$ & $\mathrm{mg} / \mathrm{Liter}$ & 648 & 730 & 89 \\
\hline $\mathrm{Cs}$ & $\mathrm{mg} / \mathrm{Liter}$ & 41 & 37 & 111 \\
\hline $\mathrm{K}$ & $\mathrm{mg} / \mathrm{Liter}$ & 4690 & 4624 & 101 \\
\hline $\mathrm{Na}$ & $\mathrm{mg} / \mathrm{Liter}$ & 104670 & 108990 & 96 \\
\hline $\mathrm{Zr}$ & $\mathrm{mg} / \mathrm{Liter}$ & 0.3 & 3 & 10 \\
\hline Chloride & $\mathrm{mg} / \mathrm{Liter}$ & 180 & 200 & 90 \\
\hline Fluoride & $\mathrm{mg} / \mathrm{Liter}$ & 760 & 1813 & 42 \\
\hline Nitrate & $\mathrm{mg} / \mathrm{Liter}$ & 60330 & 75630 & 80 \\
\hline Nitrite & $\mathrm{mg} / \mathrm{Liter}$ & 61770 & 65060 & 95 \\
\hline Phosphate & $\mathrm{mg} / \mathrm{Liter}$ & 1318 & 1503 & 88 \\
\hline Sulfate & $\mathrm{mg} / \mathrm{Liter}$ & 15740 & 17670 & 89 \\
\hline TIC & $\mathrm{mg} / \mathrm{Liter}$ & 8466 & 4620 & 183 \\
\hline
\end{tabular}


The weight percent solids concentration determined by microwave drying was $29.84 \%$. The measured aluminum level in Table 17 matches the starting reagent aluminum concentration (80\%) quite well. The high TIC level indicates that ingrowth of carbonate has occurred due to carbon dioxide reaction with the free hydroxide. A better simulant of AZ-101 must wait on availability of a well-characterized sample of AZ-101 supernate.

\section{AZ-102 Simulant}

Tank 241-AZ-102 supernate is also a B envelope waste. The simulant for this waste was developed to support the pretreatment mixing studies. The AZ-102 simulant is based upon the recently completed analysis of a B Envelope sample obtained from Hanford tank 241-AZ-102 and an earlier core sample. $^{16,17}$ To insure that the simulant included all of the trace metals, the recipe used the trace metal values from the core sample for the planned composition. The resulting simulant represents a more complete B envelope simulant than the AZ-101 simulant. The basis for AZ-102 simulant is shown in Table 18.

Table 18 Basis for AZ-102 Supernate Simulant

\begin{tabular}{|c|c|c|}
\hline Component & Moles/Liter & mg/Liter \\
\hline Aluminum & $2.80 \mathrm{E}-02$ & 755 \\
\hline Barium & $5.75 \mathrm{E}-06$ & 0.8 \\
\hline Boron & 7.77E-04 & 8.4 \\
\hline Cadmium & $1.73 \mathrm{E}-05$ & 1.9 \\
\hline Calcium & $2.69 \mathrm{E}-03$ & 108 \\
\hline Carbonate & $5.11 \mathrm{E}-01$ & 30660 \\
\hline Chromium & $1.94 \mathrm{E}-02$ & 1010.5 \\
\hline Copper & $4.95 \mathrm{E}-05$ & 3.1 \\
\hline Hydroxide & $1.09 \mathrm{E}-01$ & 1860 \\
\hline Iron & 2.01E-04 & 11.2 \\
\hline Lanthanum & $1.27 \mathrm{E}-05$ & 1.8 \\
\hline Lead & $2.88 \mathrm{E}-05$ & 6 \\
\hline Magnesium & $3.68 \mathrm{E}-05$ & 0.9 \\
\hline Manganese & $1.38 \mathrm{E}-05$ & 0.8 \\
\hline Molybdenum & $6.05 \mathrm{E}-04$ & 58 \\
\hline Neodymium & $3.80 \mathrm{E}-05$ & 5.5 \\
\hline Nickel & $3.68 \mathrm{E}-05$ & 2.2 \\
\hline Potassium & $8.10 \mathrm{E}-02$ & 3167 \\
\hline Silicon & $1.99 \mathrm{E}-02$ & 559 \\
\hline Sodium & $2.65 \mathrm{E}+00$ & 60900 \\
\hline Silver & $6.44 \mathrm{E}-05$ & 6.9 \\
\hline Strontium & $2.30 \mathrm{E}-06$ & 0.2 \\
\hline Zinc & $4.60 \mathrm{E}-06$ & 0.3 \\
\hline Zirconium & 4.72E-05 & 4.3 \\
\hline TIC & 5.11E-01 & 6135 \\
\hline TOC & $5.03 \mathrm{E}-01$ & 6038 \\
\hline Chloride & 7.00E-03 & 248 \\
\hline
\end{tabular}




\begin{tabular}{|c|c|c|}
\hline Fluoride & $5.34 \mathrm{E}-02$ & 1015 \\
\hline Nitrate & $2.73 \mathrm{E}-01$ & 16930 \\
\hline Nitrite & $6.59 \mathrm{E}-01$ & 30320 \\
\hline Oxalate & $3.21 \mathrm{E}-02$ & 2825 \\
\hline Phosphate & $5.00 \mathrm{E}-03$ & 475 \\
\hline Sulfate & $1.72 \mathrm{E}-01$ & 16520 \\
\hline
\end{tabular}

The charge balance for the analytical data in Table 18 is excellent, $97 \%$. The cations are in excess by $0.0796 \mathrm{moles} / \mathrm{Liter}$. Therefore, the hydroxide concentration was increased by $0.0796 \mathrm{moles} / \mathrm{Liter}$ to provide the balance. Note that the only organic carbon containing species is oxalate and that the oxalate only supplies $13 \%$ of the total TOC. Additional effort to measure organic species in AZ-102 supernate may be useful in improving the waste simulant. Using an expected density of 1.135 grams $/ \mathrm{mL}$, Table 19 gives the planned simulant composition.

Table 19 Composition of Tank AZ-102 Supernate Simulant

\begin{tabular}{|c|c|c|}
\hline Compounds & Formula & Grams/Liter \\
\hline Barium Nitrate & $\mathrm{Ba}\left(\mathrm{NO}_{3}\right)_{2}$ & 0.002 \\
\hline Boric Acid & $\mathrm{H}_{3} \mathrm{BO}_{3}$ & 0.048 \\
\hline Cadmium Nitrate & $\mathrm{Cd}\left(\mathrm{NO}_{3}\right)_{2} \bullet 4 \mathrm{H}_{2} \mathrm{O}$ & 0.005 \\
\hline Calcium Nitrate & $\mathrm{Ca}\left(\mathrm{NO}_{3}\right)_{2} \bullet 4 \mathrm{H}_{2} \mathrm{O}$ & 0.636 \\
\hline Copper Nitrate & $\mathrm{Cu}\left(\mathrm{NO}_{3}\right)_{2} \bullet 2.5 \mathrm{H}_{2} \mathrm{O}$ & 0.012 \\
\hline Ferric Nitrate & $\mathrm{Fe}\left(\mathrm{NO}_{3}\right)_{3} \bullet 9 \mathrm{H}_{2} \mathrm{O}$ & 0.081 \\
\hline Lanthanum Nitrate & $\mathrm{La}\left(\mathrm{NO}_{3}\right)_{3} \bullet 6 \mathrm{H}_{2} \mathrm{O}$ & 0.005 \\
\hline Lead nitrate & $\mathrm{Pb}\left(\mathrm{NO}_{3}\right)_{2}$ & 0.010 \\
\hline Magnesium Nitrate & $\mathrm{Mg}\left(\mathrm{NO}_{3}\right)_{2} \bullet 6 \mathrm{H}_{2} \mathrm{O}$ & 0.009 \\
\hline Manganous Chloride & $\mathrm{MnCl}_{2} \bullet 4 \mathrm{H}_{2} \mathrm{O}$ & 0.003 \\
\hline Neodymium Nitrate & $\mathrm{Nd}\left(\mathrm{NO}_{3}\right)_{3} \bullet 6 \mathrm{H}_{2} \mathrm{O}$ & 0.017 \\
\hline Nickel Nitrate & $\mathrm{Ni}\left(\mathrm{NO}_{3}\right)_{2} \bullet 6 \mathrm{H}_{2} \mathrm{O}$ & 0.011 \\
\hline Potassium Nitrate & $\mathrm{KNO}_{3}$ & 8.067 \\
\hline Silver Nitrate & $\mathrm{AgNO}_{3}$ & 0.011 \\
\hline Zinc Nitrate & $\mathrm{Zn}\left(\mathrm{NO}_{3}\right)_{2} \bullet 6 \mathrm{H}_{2} \mathrm{O}$ & 0.001 \\
\hline Zirconyl Nitrate & $\mathrm{ZrO}\left(\mathrm{NO}_{3}\right)_{2} \bullet \mathrm{xH}_{2} \mathrm{O}, \mathrm{x} \sim 1$ & 0.012 \\
\hline Sodium Chloride & $\mathrm{NaCl}$ & 0.407 \\
\hline Sodium Fluoride & $\mathrm{NaF}$ & 2.243 \\
\hline Sodium Chromate & $\mathrm{Na}_{2} \mathrm{CrO}_{4}$ & 3.148 \\
\hline Sodium Sulfate & $\mathrm{Na}_{2} \mathrm{SO}_{4}$ & 24.428 \\
\hline Potassium Molybdate & $\mathrm{K}_{2} \mathrm{MoO}_{4}$ & 0.144 \\
\hline Aluminum Trihydroxide & $\mathrm{Al}(\mathrm{OH})_{3}$ & 2.183 \\
\hline Sodium Hydroxide & $\mathrm{NaOH}$ & 8.772 \\
\hline Sodium meta-silicate & $\mathrm{Na}_{2} \mathrm{SiO}_{3} \bullet 9 \mathrm{H}_{2} \mathrm{O}$ & 5.654 \\
\hline Sodium Oxalate & $\mathrm{Na}_{2} \mathrm{C}_{2} \mathrm{O}_{4}$ & 4.301 \\
\hline Sodium Phosphate & $\mathrm{Na}_{3} \mathrm{PO}_{4} \bullet 12 \mathrm{H}_{2} \mathrm{O}$ & 1.901 \\
\hline Sodium Carbonate & $\mathrm{Na}_{2} \mathrm{CO}_{3}$ & 54.153 \\
\hline Sodium Nitrate & $\mathrm{NaNO}_{3}$ & 15.858 \\
\hline Sodium Nitrite & $\mathrm{NaNO}_{2}$ & 45.475 \\
\hline Water & $\mathrm{H}_{2} \mathrm{O}$ & 952.85 \\
\hline
\end{tabular}


The measured density of a test batch of the simulant was $1.118 \mathrm{~g} / \mathrm{mL}$ and the weight percent total solids was $15.76 \%$. After allowing the test batch to equilibrate for more than thirty days the composition of the supernate was analyzed and the results versus the planned concentration are shown in Table 20. 
Table 20 Analytical Results for the AZ-102 Supernate Simulant

\begin{tabular}{|c|c|c|c|c|}
\hline Component & Units & Found & Planned & $\%$ of Target \\
\hline $\mathrm{Ag}$ & $\mathrm{mg} /$ Liter & $<0.3$ & 6.9 & $<4$ \\
\hline $\mathrm{Al}$ & $\mathrm{mg} /$ Liter & 230 & 755 & 30 \\
\hline $\mathrm{B}$ & Mg/Liter & 7.3 & 8.4 & 87 \\
\hline $\mathrm{Ba}$ & $\mathrm{mg} /$ Liter & 0.01 & 0.8 & 1 \\
\hline $\mathrm{Ca}$ & $\mathrm{mg} /$ Liter & 4.8 & 108 & 4 \\
\hline $\mathrm{Cd}$ & $\mathrm{mg} /$ Liter & 0.05 & 1.9 & 3 \\
\hline $\mathrm{Cr}$ & $\mathrm{mg} /$ Liter & 865 & 1010 & 86 \\
\hline $\mathrm{Cu}$ & $\mathrm{mg} /$ Liter & 0.18 & 3.1 & 6 \\
\hline $\mathrm{Fe}$ & $\mathrm{mg} /$ Liter & 0.23 & 11.2 & 2 \\
\hline $\mathrm{K}$ & $\mathrm{mg} /$ Liter & 3150 & 3167 & 99 \\
\hline $\mathrm{La}$ & $\mathrm{mg} /$ Liter & $<0.06$ & 1.8 & $<3$ \\
\hline $\mathrm{Mg}$ & $\mathrm{mg} /$ Liter & $<0.09$ & 0.9 & $<10$ \\
\hline $\mathrm{Mn}$ & mg/Liter & $<0.01$ & 0.8 & $<1$ \\
\hline Mo & $\mathrm{mg} /$ Liter & 58 & 58 & 100 \\
\hline $\mathrm{Na}$ & $\mathrm{mg} /$ Liter & 58070 & 60900 & 95 \\
\hline $\mathrm{Nd}$ & $\mathrm{mg} /$ Liter & $<0.3$ & 5.5 & $<5$ \\
\hline $\mathrm{Ni}$ & $\mathrm{mg} /$ Liter & $<0.06$ & 2.2 & $<3$ \\
\hline $\mathrm{Pb}$ & $\mathrm{mg} /$ Liter & $<0.6$ & 6 & $<10$ \\
\hline $\mathrm{Si}$ & $\mathrm{mg} /$ Liter & 121 & 559 & 22 \\
\hline $\mathrm{Sr}$ & $\mathrm{mg} /$ Liter & 0.05 & 0.2 & 25 \\
\hline $\mathrm{Zr}$ & $\mathrm{mg} /$ Liter & 0.43 & 4.3 & 10 \\
\hline Chloride & mg/Liter & 201 & 248 & 81 \\
\hline Fluoride & mg/Liter & 1111 & 1015 & 109 \\
\hline Nitrate & mg/Liter & 15360 & 16930 & 91 \\
\hline Nitrite & mg/Liter & 31050 & 30320 & 102 \\
\hline Oxalate & $\mathrm{mg} /$ Liter & 2671 & 2825 & 95 \\
\hline Phosphate & $\mathrm{mg} /$ Liter & 375 & 475 & 79 \\
\hline Sulfate & $\mathrm{mg} /$ Liter & 14848 & 16520 & 90 \\
\hline TIC & $\mathrm{mg} /$ Liter & 8946 & 6135 & 146 \\
\hline TOC & $\mathrm{mg} /$ Liter & 1052 & 771 & 136 \\
\hline Aluminate & Molar & 0.03 & 0.028 & 107 \\
\hline Carbonate & Molar & 0.464 & 0.511 & 91 \\
\hline Free Hydroxide & Molar & 0.196 & 0.109 & 180 \\
\hline
\end{tabular}

Since the simulant does not contain any complexing agents or other organic ions other than oxalate anion, the result of so many of the trace species missing the target value is not a surprise. Without the aid of a complexing mechanism, the solubility of most of these metals in a sodium hydroxide solution is extremely small. Additionally, a relatively high concentration of oxalate anion would reduce the solubility of $\mathrm{Ca}, \mathrm{La}, \mathrm{Nd}$ and other metals which form insoluble oxalate precipitates. Additional analytical work on the AZ-102 supernate may provide an answer to the solubility problem. The low level of aluminum that was maintained in the solution could be due to depletion of the small amount of hydroxide in this simulant. The depletion mechanism could be due to carbon dioxide absorption since the TIC result 
suggests an ingrowth in carbonate. This simulant illustrates the possibly delicate balance that can occur with the more dilute simulants due to the conversion of free hydroxide to carbonate. The titration results reported for aluminate, carbonate and free hydroxide also illustrate the difficulty of using titration methods based upon differences between results. A shift in the large carbonate result would produce large swings in both the aluminate and the free hydroxide results.

\section{Envelope C Simulants}

As previously mentioned, the $\mathrm{C}$ waste was produced in the Hanford $\mathrm{B}$ plant during the $\mathrm{Cs} / \mathrm{Sr}$ separation and encapsulation process. The waste is characterized by the high organic carbon content due to the presence of organic complexing agents and their decomposition products. Due to the complexing agents, the concentration of ${ }^{90} \mathrm{Sr}$ and TRU will require removal using the $\mathrm{Sr} / \mathrm{TRU}$ precipitation and filtration process. Removal of ${ }^{137} \mathrm{Cs}$ and ${ }^{99} \mathrm{Tc}$ by ion exchange will also be required. The tanks within the C envelope are 241-AN-102 and 241-AN-107. Currently, only a simulant for AN-107 has been developed.

\section{Approved C Simulant - AN-107 Simulant}

The supernate within tank AN-107 is known as complex concentrate since it contains high levels of complexed metals. A successful simulant must have sufficient complexing agents present to duplicate the soluble metal concentrations observed within the waste. The AN-107 simulant will be used for testing the following processes: ion exchange, $\mathrm{Sr} / \mathrm{TRU}$ precipitation, pilot-scale crossflow filtration, lowpressure evaporation, sulfate removal (no longer included in RPP-WTP reference flowsheet) and low activity waste vitrification. The analytical basis for the simulant composition for all but one component

come from recent waste samples. ${ }^{18,19}$ One waste component, sodium gluconate, is based upon process knowledge and history.

Initial tests of the $\mathrm{C}$ simulant were not successful at preventing the precipitation of metals upon the addition of sodium hydroxide. The tests varied the order of addition of both the complexing agents and the aluminum. The oxidation state of iron was also tested by using $\mathrm{Fe}$ (II) instead of $\mathrm{Fe}(\mathrm{III})$ in the formulation. Finally, the test mixture was heated to $80 \mathrm{C}$ to determine if temperature could aid in generating the metal complexes.

The Hanford B plant consumption of sodium gluconate was greater than 4500 kilograms. per year. After reviewing the negative results with the customer and reviewing the Hanford B plant process history, sodium gluconate was added to the simulant formulation at 0.2 moles/Liter prior to the addition of the sodium hydroxide. The gluconate (sequestering agent) prevented the precipitation of the strontium and iron from test solutions under precipitation treatment, thus it was considered to be much too high. 
The final gluconate concentration for this simulant is not based upon a measured concentration since a method for analyzing for gluconate in the $\mathrm{C}$ waste stream has not yet been developed. The current concentration used, 0.018 molar, was agreed to based upon the results of iron precipitation tests from the Sr/TRU precipitation program. ${ }^{27}$ Those tests varied the gluconate level and correlated it with iron solubility. Nonradioactive Cells Filter work also examined the role of gluconate in complexing metals and found that gluconate is a powerful complexant in these alkaline solutions. ${ }^{28}$ Since the soluble iron:gluconate molar ratio was at least $1: 1$ and possibly $2: 1$ or more, the $0.018 \mathrm{M}$ level was chosen. It is approximately half of the iron concentration in the real waste. The analytical basis for the AN-107 simulant is listed in Table 21. Similar to the A envelope simulant, the Cs value is based upon the measured ${ }^{137} \mathrm{Cs}$ value and the assumption that ${ }^{137} \mathrm{Cs}$ is $1 / 3$ of the total cesium. The $\mathrm{Sr}$ concentration is based on ${ }^{90} \mathrm{Sr}$ making up $10 \%$ of the total $\mathrm{Sr}$ in the waste. The bases for the organic compounds that are in the AN-107 simulant are listed in Table 22. Gluconate ion is not listed in Table 22 since it is not based on an analytically measured value.

Table 21 Analytical Basis for Approved C Simulant based on AN-107

\begin{tabular}{|c|c|c|}
\hline Component & Moles/Liter & mg/Liter \\
\hline Aluminum & $1.43 \mathrm{E}-02$ & 386 \\
\hline Ammonium & $1.22 \mathrm{E}-03$ & 22 \\
\hline Barium & $5.42 \mathrm{E}-05$ & 7 \\
\hline Boron & $3.24 \mathrm{E}-03$ & 35 \\
\hline Cadmium & $5.70 \mathrm{E}-04$ & 64 \\
\hline Calcium & $1.47 \mathrm{E}-02$ & 591 \\
\hline Carbonate & $1.40 \mathrm{E}+00$ & 83936 \\
\hline Cesium & $1.40 \mathrm{E}-04$ & 18.6 \\
\hline Cerium & $3.77 \mathrm{E}-04$ & 53 \\
\hline Chromium & $3.38 \mathrm{E}-03$ & 176 \\
\hline Copper & $4.74 \mathrm{E}-04$ & 30 \\
\hline Hydroxide & $2.00 \mathrm{E}-02$ & 340 \\
\hline Iron & $3.03 \mathrm{E}-02$ & 1690 \\
\hline Lanthanum & $3.24 \mathrm{E}-04$ & 46 \\
\hline Lead & $1.87 \mathrm{E}-03$ & 388 \\
\hline Magnesium & $1.03 \mathrm{E}-03$ & 25 \\
\hline Manganese & $1.02 \mathrm{E}-02$ & 563 \\
\hline Molybdenum & $3.73 \mathrm{E}-04$ & 36 \\
\hline Neodymium & $6.65 \mathrm{E}-04$ & 96 \\
\hline Nickel & $9.03 \mathrm{E}-03$ & 530 \\
\hline Potassium & $4.63 \mathrm{E}-02$ & 1810 \\
\hline Selenium & $6.33 \mathrm{E}-06$ & 1 \\
\hline Silver & $1.33 \mathrm{E}-04$ & 14 \\
\hline Sodium & $8.48 \mathrm{E}+00$ & 195000 \\
\hline Zinc & $6.93 \mathrm{E}-04$ & 45 \\
\hline Zirconium & $7.67 \mathrm{E}-04$ & 70 \\
\hline TIC & $1.40 \mathrm{E}+00$ & 16800 \\
\hline TOC & $3.36 \mathrm{E}+00$ & 40400 \\
\hline & & \\
\hline & & \\
\hline
\end{tabular}




\begin{tabular}{|c|c|c|}
\hline Chloride & $5.16 \mathrm{E}-02$ & 1830 \\
\hline Fluoride & $7.00 \mathrm{E}-03$ & 133 \\
\hline Nitrate & $3.71 \mathrm{E}+00$ & 230000 \\
\hline Nitrite & $1.33 \mathrm{E}+00$ & 61000 \\
\hline Phosphate & $1.17 \mathrm{E}-02$ & 1110 \\
\hline Sulfate & $8.59 \mathrm{E}-02$ & 8250 \\
\hline
\end{tabular}

Table 22 Organic Basis for Approved C Simulant from AN-107

\begin{tabular}{|c|c|c|}
\hline Component & Moles/Liter & $\mathbf{~ m g / L i t e r ~}$ \\
\hline Acetate & $1.86 \mathrm{E}-02$ & 1100 \\
\hline $\begin{array}{c}\text { Ethylenediaminetetraacet } \\
\text { ate (EDTA) }\end{array}$ & $1.95 \mathrm{E}-02$ & 5620 \\
\hline Formate & $2.31 \mathrm{E}-01$ & 10400 \\
\hline Glycolate & $2.48 \mathrm{E}-01$ & 18600 \\
\hline $\begin{array}{c}\mathrm{n}- \\
\text { Hydroxyethylenediamine } \\
\text { triacetate (HEDTA) }\end{array}$ & $7.78 \mathrm{E}-03$ & 2140 \\
\hline Oxalate & $9.38 \mathrm{E}-03$ & 826 \\
\hline Nitrilotriacetate (NTA) & $2.98 \mathrm{e}-03$ & 561 \\
\hline Citrate & $4.49 \mathrm{e}-02$ & 8495 \\
\hline Iminodiacetate (IDA) & $4.54 \mathrm{e}-02$ & 5947 \\
\hline
\end{tabular}

The charge balance based on tables 21 and 22 shows an excess of negative ions by 0.31 mole/Liter compared to a total of 9.04 moles/Liter (balance is $96 \%$ ). Since the hydroxide level is very low, 0.02 moles/Liter (important characteristic of AN-107 supernate), the hydroxide could not be reduced by $0.31 \mathrm{moles} / \mathrm{Liter}$. Therefore, the Na ion concentration was increased by 0.31 moles/Liter to balance the anions. The sodium gluconate level was set to 0.018 moles/Liter. Based upon a volumetric preparation of the simulant, the density of the undiluted AN-107 simulant is $1.429 \mathrm{~g} / \mathrm{mL}$. Appendix C details the computations performed to transform the data in Tables 21 and 22 into the compounds listed in Table 23. 
Table 23 Approved C Simulant based on Tank AN-107 Supernate

\begin{tabular}{|c|c|c|}
\hline Compounds & Formula & Grams/Liter \\
\hline Aluminum Nitrate & $\mathrm{Al}\left(\mathrm{NO}_{3}\right)_{3} \bullet 9 \mathrm{H}_{2} \mathrm{O}$ & 5.367 \\
\hline Ammonium Acetate & NH4CH3COO & 0.094 \\
\hline Barium Nitrate & $\mathrm{Ba}\left(\mathrm{NO}_{3}\right)_{2}$ & 0.014 \\
\hline Boric Acid & $\mathrm{H}_{3} \mathrm{BO}_{3}$ & 0.200 \\
\hline Cadmium Nitrate & $\mathrm{Cd}\left(\mathrm{NO}_{3}\right)_{2} \bullet 4 \mathrm{H}_{2} \mathrm{O}$ & 0.176 \\
\hline Calcium Nitrate & $\mathrm{Ca}\left(\mathrm{NO}_{3}\right)_{2} \bullet 4 \mathrm{H}_{2} \mathrm{O}$ & 3.482 \\
\hline Cerium Nitrate & $\mathrm{Ce}\left(\mathrm{NO}_{3}\right)_{3} \bullet 6 \mathrm{H}_{2} \mathrm{O}$ & 0.164 \\
\hline Cesium Nitrate & $\mathrm{CsNO}_{3}$ & 0.027 \\
\hline Copper Nitrate & $\mathrm{Cu}\left(\mathrm{NO}_{3}\right)_{2} \bullet 2.5 \mathrm{H}_{2} \mathrm{O}$ & 0.110 \\
\hline Disodium EDTA & $\mathrm{C}_{10} \mathrm{H}_{14} \mathrm{~N}_{2} \mathrm{Na}_{2} \mathrm{O}_{8} \bullet 2 \mathrm{H}_{2} \mathrm{O}$ & 7.259 \\
\hline Ferric Nitrate & $\mathrm{Fe}\left(\mathrm{NO}_{3}\right)_{3} \bullet 9 \mathrm{H}_{2} \mathrm{O}$ & 12.226 \\
\hline HEDTA Acid & $\mathrm{C}_{10} \mathrm{H}_{18} \mathrm{~N}_{2} \mathrm{O}_{7}$ & 2.164 \\
\hline Lanthanum Nitrate & $\mathrm{La}\left(\mathrm{NO}_{3}\right)_{3} \bullet 6 \mathrm{H}_{2} \mathrm{O}$ & 0.142 \\
\hline Lead nitrate & $\mathrm{Pb}\left(\mathrm{NO}_{3}\right)_{2}$ & 0.620 \\
\hline Magnesium Nitrate & $\mathrm{Mg}\left(\mathrm{NO}_{3}\right)_{2} \bullet 6 \mathrm{H}_{2} \mathrm{O}$ & 0.264 \\
\hline Manganous Chloride & $\mathrm{MnCl}_{2} \bullet 4 \mathrm{H}_{2} \mathrm{O}$ & 2.028 \\
\hline Neodymium Nitrate & $\mathrm{Nd}\left(\mathrm{NO}_{3}\right)_{3} \bullet 6 \mathrm{H}_{2} \mathrm{O}$ & 0.291 \\
\hline Nickel Nitrate & $\mathrm{Ni}\left(\mathrm{NO}_{3}\right)_{2} \bullet 6 \mathrm{H}_{2} \mathrm{O}$ & 2.626 \\
\hline Potassium Nitrate & $\mathrm{KNO}_{3}$ & 4.605 \\
\hline Silver Nitrate & $\mathrm{AgNO}_{3}$ & 0.023 \\
\hline Strontium Nitrate & $\mathrm{Sr}\left(\mathrm{NO}_{3}\right)_{2}$ & 0.016 \\
\hline Zinc Nitrate & $\mathrm{Zn}\left(\mathrm{NO}_{3}\right)_{2} \bullet 6 \mathrm{H}_{2} \mathrm{O}$ & 0.206 \\
\hline Zirconyl Nitrate & $\mathrm{ZrO}\left(\mathrm{NO}_{3}\right)_{2} \bullet \mathrm{xH}_{2} \mathrm{O}, \mathrm{x} \sim 1$ & 0.191 \\
\hline Glycolic Acid & $\mathrm{HOCH}_{2} \mathrm{COOH}, 70 \mathrm{wt} \%$ & 26.928 \\
\hline Sodium Gluconate & $\mathrm{C}_{6} \mathrm{H}_{11} \mathrm{O}_{7} \mathrm{Na}$ & 3.927 \\
\hline Citric Acid & $\mathrm{C}_{6} \mathrm{H}_{8} \mathrm{O}_{7} \bullet \mathrm{H}_{2} \mathrm{O}$ & 9.440 \\
\hline Nitrilotriacetic Acid & $\mathrm{C}_{6} \mathrm{H}_{9} \mathrm{NO}_{6}$ & 0.570 \\
\hline Iminodiacetic Acid & $\mathrm{C}_{4} \mathrm{H}_{7} \mathrm{NO}_{4}$ & 6.038 \\
\hline Sodium Chloride & $\mathrm{NaCl}$ & 1.819 \\
\hline Sodium Fluoride & $\mathrm{NaF}$ & 0.294 \\
\hline Sodium Chromate & $\mathrm{Na}_{2} \mathrm{CrO}_{4}$ & 0.548 \\
\hline Sodium Sulfate & $\mathrm{Na}_{2} \mathrm{SO}_{4}$ & 12.199 \\
\hline Potassium Molybdate & $\mathrm{K}_{2} \mathrm{MoO}_{4}$ & 0.089 \\
\hline Sodium Hydroxide & $\mathrm{NaOH}$ & 25.263 \\
\hline Sodium Oxalate & $\mathrm{Na}_{2} \mathrm{C}_{2} \mathrm{O}_{4}$ & 1.257 \\
\hline Sodium Acetate & $\mathrm{NaCH}_{3} \mathrm{COO} \bullet 3 \mathrm{H}_{2} \mathrm{O}$ & 2.369 \\
\hline Sodium Formate & $\mathrm{NaHCOO}$ & 15.712 \\
\hline Sodium Phosphate & $\mathrm{Na}_{3} \mathrm{PO}_{4} \bullet 12 \mathrm{H}_{2} \mathrm{O}$ & 4.443 \\
\hline Sodium Carbonate & $\mathrm{Na}_{2} \mathrm{CO}_{3}$ & 148.250 \\
\hline Sodium Nitrate & $\mathrm{NaNO}_{3}$ & 294.672 \\
\hline Sodium Nitrite & $\mathrm{NaNO}_{2}$ & 91.489 \\
\hline Water & $\mathrm{H}_{2} \mathrm{O}$ & 726.96 \\
\hline
\end{tabular}


Testing the AN-107 simulant gave a density of $1.44 \mathrm{~g} / \mathrm{mL}$ at $20 \mathrm{C}$. The simulant produced a solution with a deep brown color and just a small amount of solids but did require several hours of mixing to dissolve the added compounds. The inorganic and organic analytical results for the AN-107 simulant are listed in Tables 24 and Table 25 respectively.

Table 24 Inorganic Analytical Results for AN-107 Simulant

\begin{tabular}{|c|c|c|c|c|}
\hline Component & Units & Found & Planned & \% of Target \\
\hline $\mathrm{Al}$ & $\mathrm{mg} / \mathrm{L}$ & 194 & 386 & 50 \\
\hline $\mathrm{B}$ & $\mathrm{mg} / \mathrm{L}$ & 38 & 35 & 108 \\
\hline $\mathrm{Ba}$ & $\mathrm{mg} / \mathrm{L}$ & 0.17 & 7 & 2 \\
\hline $\mathrm{Ca}$ & $\mathrm{mg} / \mathrm{L}$ & 138 & 591 & 23 \\
\hline $\mathrm{Ce}$ & $\mathrm{mg} / \mathrm{L}$ & 50.2 & 53 & 95 \\
\hline $\mathrm{Cr}$ & $\mathrm{mg} / \mathrm{L}$ & 148 & 176 & 84 \\
\hline Cs & $\mathrm{mg} / \mathrm{L}$ & 22.3 & 18.6 & 120 \\
\hline $\mathrm{Cu}$ & $\mathrm{mg} / \mathrm{L}$ & 32 & 30 & 106 \\
\hline $\mathrm{Fe}$ & $\mathrm{mg} / \mathrm{L}$ & 1623 & 1690 & 96 \\
\hline $\mathrm{K}$ & $\mathrm{mg} / \mathrm{L}$ & 1921 & 1810 & 106 \\
\hline $\mathrm{La}$ & $\mathrm{mg} / \mathrm{L}$ & 40 & 46 & 88 \\
\hline $\mathrm{Mg}$ & $\mathrm{mg} / \mathrm{L}$ & 20 & 25 & 79 \\
\hline $\mathrm{Mn}$ & $\mathrm{mg} / \mathrm{L}$ & 564 & 563 & 100 \\
\hline Mo & $\mathrm{mg} / \mathrm{L}$ & 36 & 36 & 100 \\
\hline $\mathrm{Na}$ & $\mathrm{mg} / \mathrm{L}$ & 188170 & 195000 & 96 \\
\hline $\mathrm{Na}$ & $\mathrm{mg} / \mathrm{L}$ & 201400 & 195000 & 103 \\
\hline $\mathrm{Nd}$ & $\mathrm{mg} / \mathrm{L}$ & 84.4 & 96 & 88 \\
\hline $\mathrm{Ni}$ & $\mathrm{mg} / \mathrm{L}$ & 501 & 530 & 95 \\
\hline $\mathrm{P}$ & $\mathrm{mg} / \mathrm{L}$ & 420 & 362 & 116 \\
\hline $\mathrm{Pb}$ & $\mathrm{Mg} / \mathrm{L}$ & 364 & 388 & 94 \\
\hline $\mathrm{Sr}$ & $\mathrm{mg} / \mathrm{L}$ & 1.3 & 6.6 & 20 \\
\hline $\mathrm{Zn}$ & $\mathrm{mg} / \mathrm{L}$ & 44 & 45 & 98 \\
\hline $\mathrm{Zr}$ & $\mathrm{mg} / \mathrm{L}$ & 45 & 70 & 64 \\
\hline Chloride & $\mathrm{mg} / \mathrm{L}$ & 1330 & 1100 & 121 \\
\hline Fluoride & $\mathrm{mg} / \mathrm{L}$ & 3430 & 133 & 2579 \\
\hline Formate & $\mathrm{mg} / \mathrm{L}$ & 11232 & 10400 & 108 \\
\hline Nitrate & $\mathrm{mg} / \mathrm{L}$ & 213930 & 230000 & 93 \\
\hline Nitrite & $\mathrm{mg} / \mathrm{L}$ & 57090 & 61000 & 94 \\
\hline Oxalate & $\mathrm{mg} / \mathrm{L}$ & 335 & 826 & 41 \\
\hline Phosphate & $\mathrm{mg} / \mathrm{L}$ & 1500 & 1110 & 135 \\
\hline Sulfate & $\mathrm{mg} / \mathrm{L}$ & 7280 & 8250 & 88 \\
\hline TIC & $\mathrm{mg} / \mathrm{L}$ & 16100 & 16800 & 96 \\
\hline TOC & $\mathrm{mg} / \mathrm{L}$ & 15800 & 12450 & 127 \\
\hline
\end{tabular}


Table 25 Organic Analytical Results for AN-107 Simulant

\begin{tabular}{|c|c|c|c|c|}
\hline Component & Units & Found & Planned & \% of Target \\
\hline EDTA & $\mathrm{mg} / \mathrm{L}$ & 1088 & 5620 & 19 \\
\hline HEDTA & $\mathrm{mg} / \mathrm{L}$ & 3231 & 2140 & 151 \\
\hline Glycolate & $\mathrm{mg} / \mathrm{L}$ & 18864 & 18600 & 101 \\
\hline Citrate & $\mathrm{mg} / \mathrm{L}$ & 8952 & 8495 & 105 \\
\hline Formate & $\mathrm{mg} / \mathrm{L}$ & 12374 & 10400 & 119 \\
\hline Acetate & $\mathrm{mg} / \mathrm{L}$ & 964 & 1100 & 88 \\
\hline Iminodiacetic Acid & $\mathrm{mg} / \mathrm{L}$ & 8251 & 5947 & 139 \\
\hline
\end{tabular}

The exceptionally high fluoride result listed in Table 24 was obtained by ion chromatography, which has known interference's for fluoride due to weak organic acid anions such as acetate and glycolate. An alternative analytical technique such as capillary electrophoresis may be necessary to properly measure the fluoride content. The low aluminum result is probably due to the extremely low hydroxide concentration of the AN-107 simulant ( $\mathrm{pH}$ 12). Any shift in free hydroxide due to $\mathrm{CO}_{2}$ absorption would cause a drop in soluble aluminum. The organic analytical results, which are more than $30 \%$ off from the target value, were for new methods recently implemented at SRTC. These methods require measuring a recovery and adjusting the results for the recovery. If the recovery measurement does not reproduce the sample measurement, the adjustment can introduce substantial errors. Additional testing should clarify the source of the problems.

Several features make this an interesting simulant. The first is the extremely high organic content of the waste and of the simulant. Any attempt to match the TOC of the waste would introduce excess levels of organic compounds beyond what can be measured. The actual waste has a much longer list of organic compounds, most of which can act as complexing agents. The compounds used in the simulant are most of the major compounds, especially those that were originally used in the process. Iminodiacetate ion was added to represent the typical decomposition products of the starting complexing agents. Second, very high carbonate level in the simulant led to the formation of tabular crystal over a 36 day period which were identified as the monohydrate of sodium carbonate. ${ }^{9}$ Third, turbidity measurements during the simulant pretreatment mixing study demonstrated that over extended periods, more than 60 days, the simulant slowly begins to produce additional fine solids. ${ }^{9}$ Currently, these solids have not been conclusively identified. Finally, the lower than planned levels of some of the +2 cations may be an indication that some additional complexing agent or a higher level of gluconate ion may be necessary to prevent precipitation of these ions by oxalate, which was also lower than planned.

Relatively large volumes of simulant are required for the pilot ion exchange and Sr/TRU precipitation/crossflow filtration studies. To assist in producing the diluted supernate simulant, a series of diluted AN-107 simulants were prepared volumetrically so that the density of the diluted simulant could be measured. Table 26 lists the measured densities and the weight percent solids calculated for these dilutions as a function of the sodium ion concentration. The densities listed in table 4 were measured at 20 to $22 \mathrm{C}$ (ambient lab temperatures). The weight percent solids value represents the 
solids with no waters of hydration and is a theoretical (computed) value. This should be used as a guide since measuring the weight percent solids by oven or microwave drying may lead to varying levels of dehydration and possibly some decomposition and therefore a different value.

Table 26 An-107 Simulant Density and Weight Percent Solids

\begin{tabular}{|c|cc|}
\hline Na Concentration, Molar & Density, $\mathrm{g} / \mathrm{mL}$ & Wt \% Anhydrous Solids \\
\hline 2.03 & 1.108 & 13.85 \\
\hline 4.53 & 1.213 & 28.22 \\
\hline 5.04 & 1.231 & 30.97 \\
\hline 5.55 & 1.243 & 33.75 \\
\hline 6.06 & 1.288 & 35.54 \\
\hline 7.04 & 1.331 & 40.02 \\
\hline 8.85 & 1.386 & 48.28 \\
\hline
\end{tabular}

The sodium concentration $(\mathrm{X}$, molarity) versus the density $(\mathrm{Y}, \mathrm{gm} / \mathrm{L})$ can be fit empirically to the following simple equation to allow predictions of densities for different sodium concentrations when the supernate is diluted:

$$
Y^{2}=0.998+0.1054 X \quad \text { (3) }
$$

Besides the measured values, at infinite dilution, the sodium concentration would be zero and the density would be that of water, $0.997 \mathrm{~g} / \mathrm{mL}$. This assumption was also included in the data set that was fitted. Figure 5 display the fitted curve versus the measured and assumed data point. 


\section{Figure 5 Envelope C Simulant Density as a Function of Na Concentration}

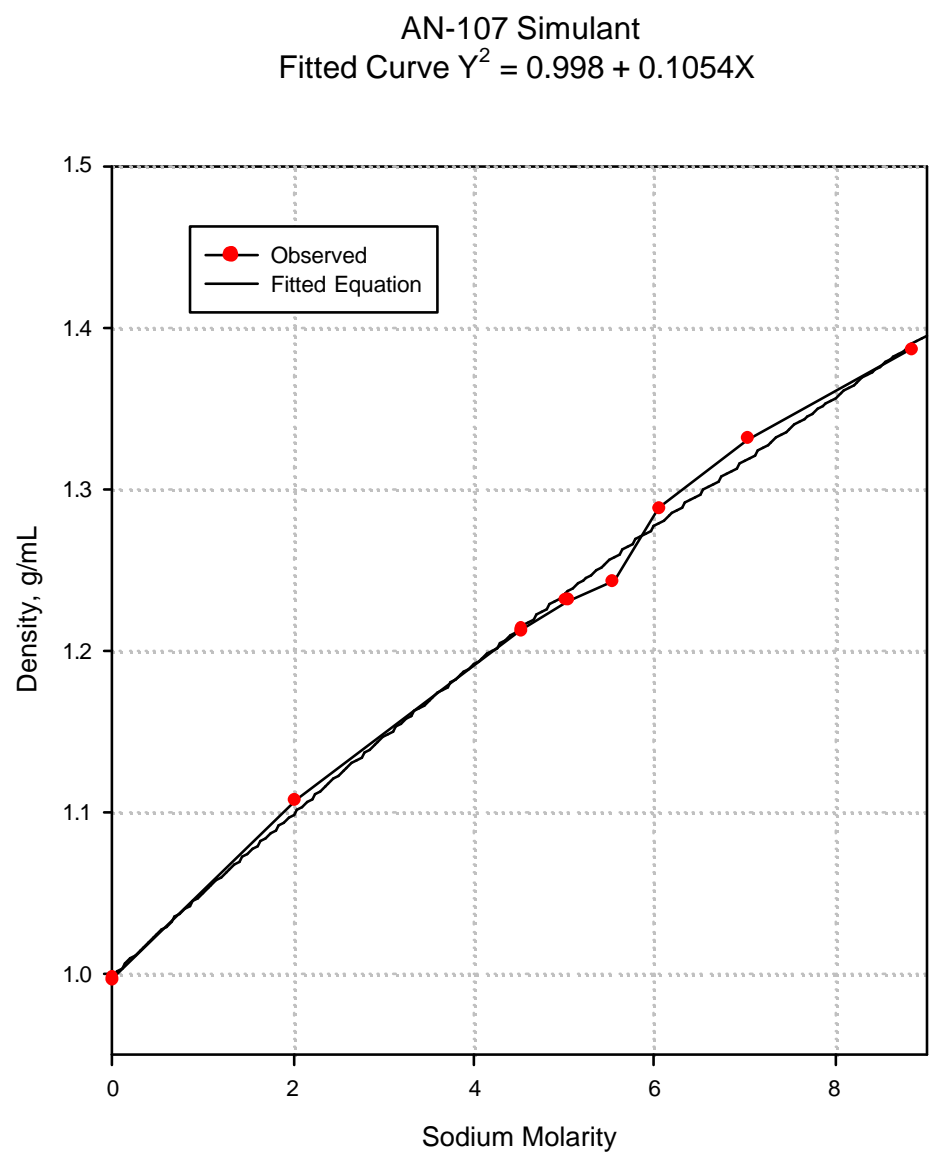

The $\mathrm{r} 2$ value for the fit is 0.995 . The relationship can be used for this specific ratio of compounds across the range of measured concentrations but should not be extended to other simulant recipes except as a very crude estimate.

The weight percent solids (anhydrous) can also be calculated for a specific sodium concentration and then also plotted and fitted to a curve. Note that the assumption is made that at 0.0 Molar $\mathrm{Na}(\mathrm{X})$, the weight percent solids (Y) is also 0.0. Figure 6 demonstrates that the polynomial listed as equation (4),

$$
Y=0.1637+6.99 X-0.179 X^{2}
$$

provides a good fit to the results without forcing an intercept at the origin. 
$Y=0.1637+6.99 X-0.179 X^{2}$

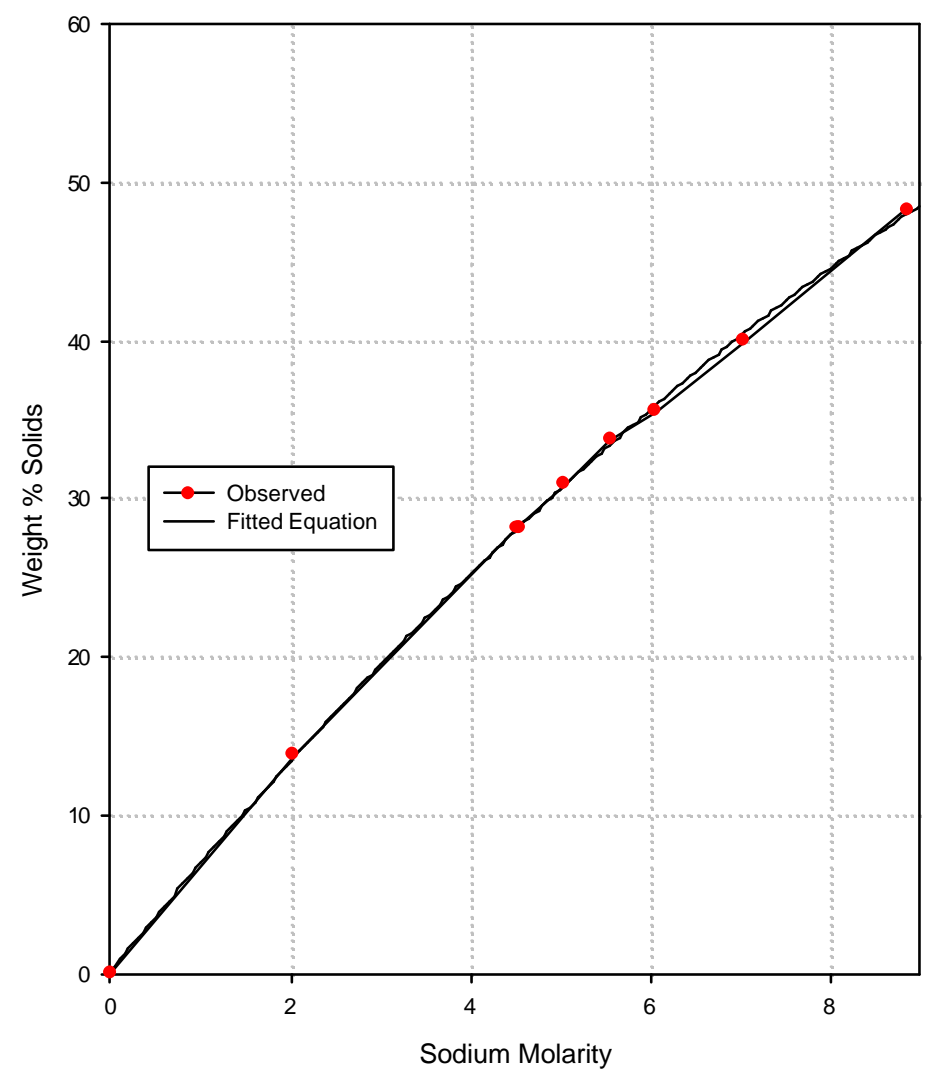

Figure 6 AN-107 Simulant Weight \% Solids (Anhydrous) as a Function of the Na Concentration

As mentioned previously, the relationship given by equation (4) is only for the composition specified for the approved AN-107 simulant. Actual measurements of weight percent solids can differ from this curve due to waters of hydration or due to actual compound decomposition. As such the curve should be used as a guide. For example, equation 4 or figure 6 can be used to estimate the Na concentration after dilution based upon a total solids measurement. 


\section{Envelope D Simulant}

The envelope D simulant represents the insoluble solids from than Hanford waste tanks that will be processed and vitrified as high activity waste. The waste is often referred to as sludge and is usually high in iron, aluminum, zirconium, manganese and nickel oxides or hydroxides. Substantial amounts of insoluble carbonates can also be present. The majority of the long term radionuclides and transuranics are present in envelope D. The initial tanks planned to be processed in the RPP-WTP that contain envelope D waste are 241-AZ-101 and 241-AZ-102. The initial work on envelope D simulant formulation focused on tank AZ-101.

\section{AZ-101 Sludge Simulant}

Unlike the other simulants described in this report, research and formulation work on the AZ-101 sludge simulant is still in progress. The information described in this section maybe superceded by later information obtained from the High Level Waste Mixing Study. ${ }^{20}$ However, the formulated composition of the AZ-101 sludge simulant will not change. For comparisons with other sludge simulants refer to the High Level Waste Mixing Study. ${ }^{20}$

Tank 241-AZ-101 served as a receiver for neutralized current acid waste and contains about 35,000 gallons of insoluble sludge solids. Because of the layered nature of the settled sludge solids, sampling of the sludge solids uses a core sampling approach. The insoluble portion of the core samples are combined and blended to represent the total, insoluble layer in the tank. However, different core samples from different locations within a tank often show shifts in waste composition due to the three dimensional variation within a settled sludge layer. The AZ-101 sludge simulant target composition is based on averaging the results from two separate AZ-101 core samples. ${ }^{21,14}$ The target composition for the AZ-101 sludge blend is shown in Table 27. Appendix D displays the spreadsheets used to calculate the values given in Table 27 and defines how the recipe for generating sludge is formed. Since the sludge is generated by reacting the metals listed in Table 27 with sodium hydroxide and sodium carbonate, a separate table defining the final sludge composition such as has been listed for the supernate simulants will not be included. 
Table 27 Blended AZ-101 Solids Composition

\begin{tabular}{|c|c|c|}
\hline Component & Grams/Liter & micrograms/gram of solids \\
\hline Aluminum & 8.970 & 57907 \\
\hline Barium & 0.328 & 2114 \\
\hline Boron & 0.124 & 803 \\
\hline Cadmium & 3.454 & 22295 \\
\hline Calcium & 1.400 & 9036 \\
\hline Cerium & 0.436 & 2817 \\
\hline Chromium & 0.347 & 2238 \\
\hline Copper & 0.152 & 979 \\
\hline Iron & 44.150 & 285023 \\
\hline Lanthanum & 1.784 & 11520 \\
\hline Lead & 0.505 & 3258 \\
\hline Magnesium & 0.249 & 1610 \\
\hline Manganese & 1.027 & 6630 \\
\hline Molybdenum & 0.022 & 144 \\
\hline Neodymium & 1.192 & 7696 \\
\hline Nickel & 2.719 & 17552 \\
\hline Potassium & 0.986 & 6365 \\
\hline Silver & 0.346 & 2235 \\
\hline Sodium & 12.853 & 82976 \\
\hline Silicon & 2.182 & 14084 \\
\hline Strontium & 0.234 & 1508 \\
\hline Titanium & 0.042 & 274 \\
\hline Zinc & 0.134 & 865 \\
\hline Zirconium & 14.772 & 95366 \\
\hline TIC & 1.109 & 7161 \\
\hline Chloride & 0.039 & 255 \\
\hline Fluoride & 0.215 & 1390 \\
\hline Nitrate & 3.909 & 25238 \\
\hline Nitrite & 5.567 & 35942 \\
\hline Phosphate & 0.260 & 1678 \\
\hline Sulfate & 1.406 & 9078 \\
\hline
\end{tabular}

The initial simulated sludge work was based upon a blend of caustic leached sludge from both tanks AZ-101 and AZ-102. Since the composition of the blended sludge was similar to the AZ-101 simulant and the preparation of the sludge was identical, the physical properties of the blended AZ-101/AZ-102 sludge simulant will be discussed. For example, the aluminum in the AZ-101/AZ-102 sludge simulant was added post precipitation of the metal cations and sludge washing just as is called for in the AZ-101 
simulant recipe. Results for an AZ-101 sludge simulant prepared in the same manner are expected to be similar.

A sludge simulant must not only match the chemical composition for the waste, it must also compare favorably with the physical properties of the waste. Amongst the physical properties important for the operation of the RPP-WTP are particle size and rheology. A particle size analysis for the AZ-101/AZ102 simulant blend after sludge washing is shown in Figure 7. A comparison of the median particle size is listed in Table 28 .

Table 28 Sludge Particle Size Comparisons

\begin{tabular}{|c|c|}
\hline Sludge & $\begin{array}{c}\text { Median Particle Size, } \\
\text { micrometers }\end{array}$ \\
\hline AZ-101 Core 1 & 9.0 \\
\hline AZ-101 Core 2 & 5.4 \\
\hline NCAW Simulant ${ }^{22}$ & 25.6 \\
\hline RFP Simulant t2 $^{22}$ & 12.4 \\
\hline SRTC AZ-101/AZ-102 Blend & 16 \\
\hline
\end{tabular}

The particle size is in the mid range of the previous simulants and not much larger than observed for the actual sludge. Since particle size is expected to be sensitive to the amount of shear, additional shearing is planned during the HLW blending studies. ${ }^{20}$ 
Hanford Waste Simulants Created to Support Research and Development on the River Protection Project - Waste Treatment Plant
SRT-RPP-2000-00017

Revision (Date): $\quad 0(02 / 22 / 2001)$

Page:

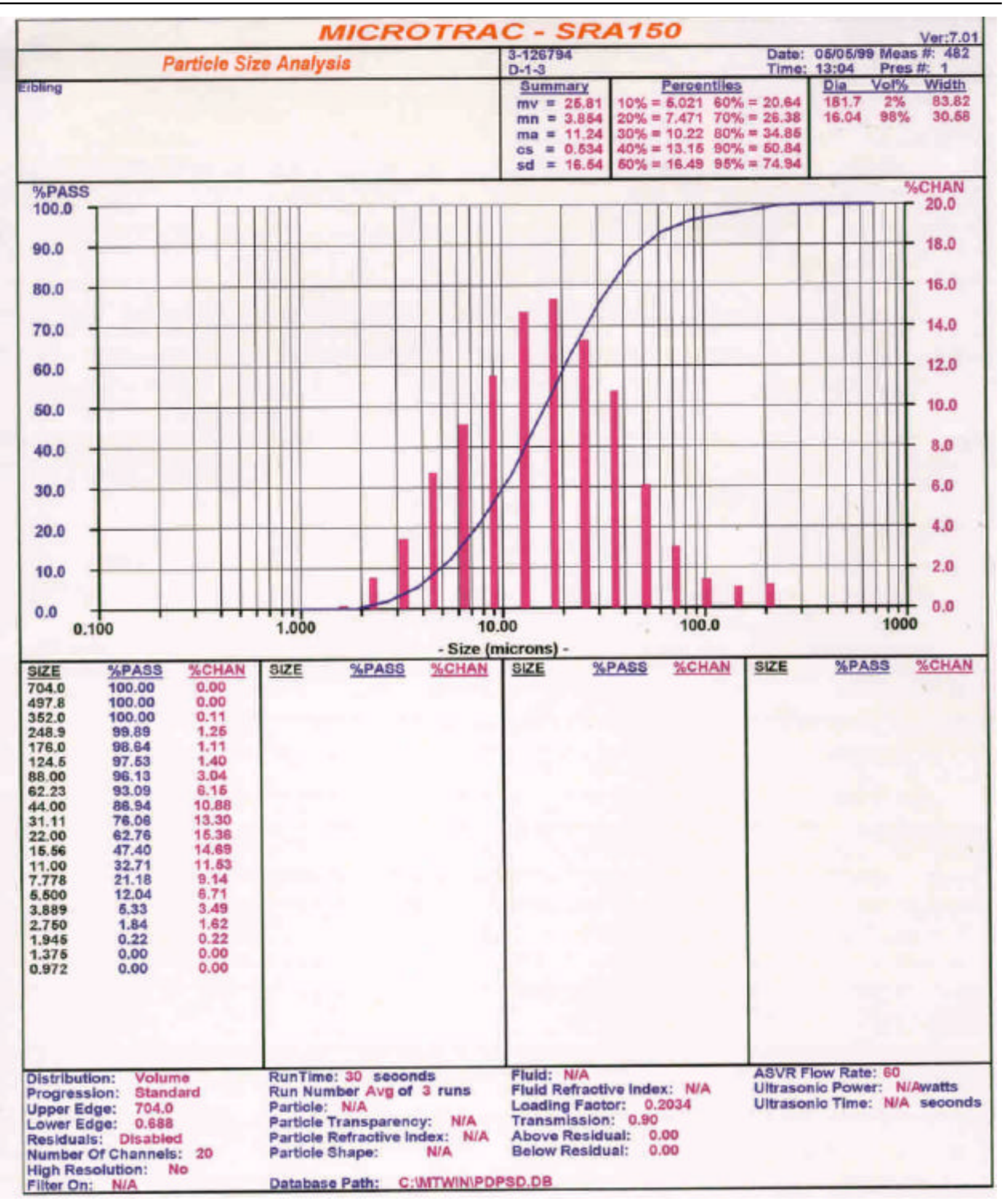

Figure 7 Particle Size analysis for Blended AZ-101/AZ-102 Sludge 
The fluid properties of the simulated sludge was studied using a Haake rheometer with a M5 measuring head. The sample was run using the MV1 geometry (concentric cylinders) at $298 \mathrm{~K}$ after verifying correct rheometer operation with a known viscosity oil. The instrument was operated in the dynamic flow curve operation with the shear ranging from zero seconds ${ }^{-1}$ to 350 seconds $^{-1}$. Figure 8 compares the flow curve for the blend simulant to information from the core samples.

Flow Curves for 10 wt \% Solids Sludges

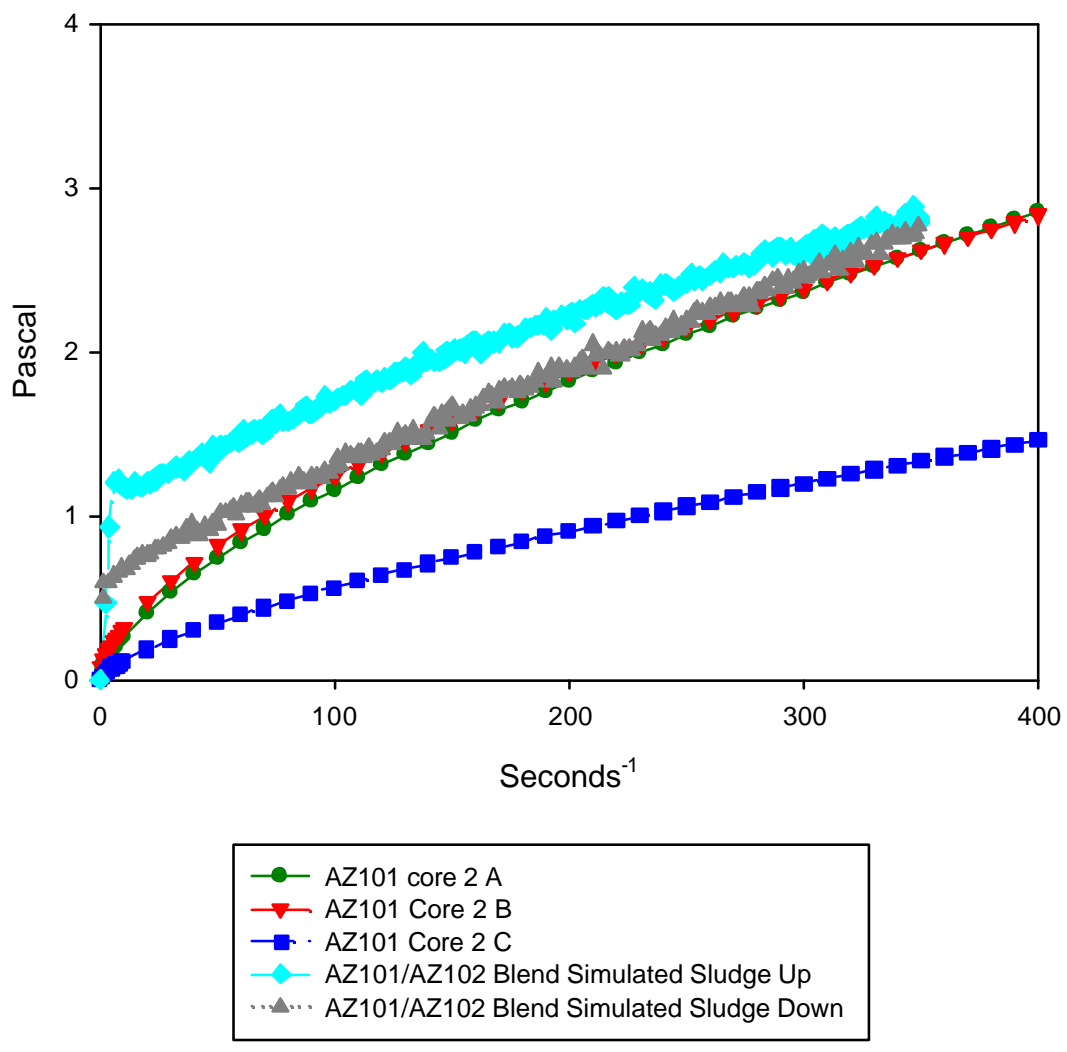

Figure 8 Rheology of AZ-101 sludge Compared to the AZ-101/AZ-102 Blend Simulant

The Blend simulant down curve indicates that the sludge is thixotropic (shear thinning). The data shown for the AZ-101 core 2 sample is actually produced from the power law model to which the data was fit. Applying a Bingham model to the core $2 \mathrm{~A}$ curve and to the up curve for the Blend simulant gives a yield stress of 0.5 and 1.2 Pascal respectively while the consistency (slope of the curve) would appear to be very similar. Additional tests with the Blend simulant have indicated that the yield stress may increase with aging. Unfortunately, when the Blend simulant was completed the SRTC rheometer was 
inoperable. The curve shown above is for the Blend simulant after 3 months of aging. This suggests that the initial yield stress of the Blend simulant may have been even closer to that of the actual waste.

Additional physical property data shall be obtained for the AZ-101 simulant in the near future. The additional studies planned are particle size before and after pumping through a high shear pump, rheology as a function of weight percent solids, and the effect of $\mathrm{pH}$ on rheological properties. The physical properties information for the AZ-101 sludge simulant will be compared to the physical properties analytical results for actual AZ-101 sludge that were recently obtained during a test of mixer pumps in tank 241-AZ-101 (HNF-7078, AZ-101 Results of Retrieval Testing of Sludge from Tank 241-AZ-101).

\section{Entrained Solids Simulants}

An entrained solids simulant is designed to represent the insoluble solids observed in decanted supernate from the Hanford waste tanks. These simulants are need for pilot crossflow filtration studies and must duplicate the expected particle size range. Two different simulants were formulated based on entrained solids in Tank AN-105 supernate and entrained solids in Tank AN-107 supernate.

\section{AN-105 Entrained Solids Simulant}

The entrained solids in Tank 241-AN-105 supernate are expected to be primarily composed of corrosion products and insoluble precipitated solids. The compositional basis for the waste simulant is derived from dilution studies of solids from AN-105. ${ }^{6}$ These studies also reported that the particle size of the washed solids had two maxima, one near 5 micrometers and a narrower distribution near 50 micrometers. Since the 50-micrometer material is expected to be easy to filter due to its size, the simulant will be composed primarily of particles of 5 micrometer and less in size. As expected, the number density is weighted to the finer particles. The elemental composition of the solids is listed in Table 29. 


\section{Table 29 Basis for Envelope A Entrained Solids from AN-105 Supernate}

\begin{tabular}{|c|c|}
\hline Component & Grams/100 grams of Sample \\
\hline TOC & 0.065 \\
\hline Al & 0.025 \\
\hline Ca & 0.008 \\
\hline Cr & 0.103 \\
\hline Fe & 0.004 \\
\hline Mn & 0.001 \\
\hline Na & 0.092 \\
\hline Ni & 0.002 \\
\hline
\end{tabular}

The strategy described for producing an entrained solids simulant was used to convert the information in Table 29 into compounds, which could be obtained in the desired particle size range. Appendix E contains the spreadsheet used to calculate compounds and estimate the mass balance. Table 30 gives the formulation for the entrained solids in terms of grams of the compound per 100 grams of entrained solids. 
Table 30 Envelope A Entrained Solids Formulation Based on Tank AN-105

\begin{tabular}{|c|c|c|}
\hline Compound & Formula & Grams/100 grams of solids \\
\hline Aluminum oxide & $\mathrm{Al}_{2} \mathrm{O}_{3}$ & 9.2 \\
\hline Calcium Oxalate & $\mathrm{CaC}_{2} \mathrm{O}_{4}$ & 5.0 \\
\hline Chromic Oxide & $\mathrm{Cr}_{2} \mathrm{O}_{3}$ & 26.0 \\
\hline Ferric Oxide & $\mathrm{Fe}_{2} \mathrm{O}_{3}$ & 1.1 \\
\hline Manganese Dioxide & $\mathrm{MnO}_{2}$ & 0.3 \\
\hline Sodium Oxalate & $\mathrm{Na}_{2} \mathrm{C}_{2} \mathrm{O}_{4}$ & 52.4 \\
\hline Nickel oxide & $\mathrm{NiO}$ & 0.5 \\
\hline Silica & $\mathrm{SiO}_{2}$ & 5.4 \\
\hline
\end{tabular}

This combination of solids calculated to be $90 \%$ of the measured, washed solids mass giving reasonable agreement with the goal. Using other species such as $\mathrm{AlOOH}$ or $\mathrm{FeOOH}$ did not improve the balance. Using other insoluble sodium species such as sodium aluminosilicate did not measurably improve the balance since the ratio of sodium to either $\mathrm{Al}$ or $\mathrm{Si}$ was so high. As mentioned above, the recommended particle size range was less than 5 micrometers

\section{AN-107 Entrained Solids Simulant}

The entrained solids in $\mathrm{C}$ envelope will experience the precipitation of strontium carbonate and manganese dioxide before being processed through a crossflow filter. Since the presence of the unwashed entrained solids may have an impact on the precipitation product, the entrained solids must represent the unwashed solids in the AN-107 supernate. While washed solids were used in the basis for the AN-105 entrained solid, the AN-107 solids must be based on unwashed solids. However, an unwashed AN-107 solids analysis was not available. Instead, an analysis of washed solids and the wash waters from washing those solids was used to reassemble the composition of the unwashed solids. ${ }^{23}$ Appendix F displays the spreadsheets used to calculate the mass of each species in the wash water at each stage of the wash. These amounts were then summed to produce a composition for the unwashed solids as shown in Table 31 . 
Table 31 Calculated Basis for the AN-107 Entrained Solids

\begin{tabular}{|c|c|}
\hline Component & Milligrams \\
\hline TOC & 55.7 \\
\hline Al & 24.7 \\
\hline Ca & 0.26 \\
\hline Cr & 2.4 \\
\hline Fe & 30.3 \\
\hline Mn & 17.7 \\
\hline Na & 205.4 \\
\hline Si & 2.2 \\
\hline TIC & 28.5 \\
\hline Fluoride & 20.6 \\
\hline Sulfate & 11.2 \\
\hline Phosphate & 21.0 \\
\hline
\end{tabular}

At this point, the entrained solids strategy can be used to assemble a possible solids composition. The more soluble species such as the fluoride, sulfate, phosphate, oxalate (from the TOC) and the carbonate (from the TIC) will obviously wash from the solids when the Sr/TRU precipitate is washed. After reviewing all of the possible combinations, the composition detailed in Table 32 was chosen as the entrained solids formulation. 


\section{Table 32 AN-107 Unwashed Entrained Solids Formulation}

\begin{tabular}{|c|c|c|}
\hline Compounds & Formula & grams/100 grams of solids \\
\hline Aluminum Oxide & $\mathrm{Al}_{2} \mathrm{O}_{3}$ & 5.1 \\
\hline Calcium Phosphate, Tribasic & $\mathrm{Ca}_{3}\left(\mathrm{PO}_{4}\right)_{2}$ & 0.1 \\
\hline Chromic Oxide & $\mathrm{Cr}_{2} \mathrm{O}_{3}$ & 0.4 \\
\hline Ferric Oxide & $\mathrm{Fe}_{2} \mathrm{O}_{3}$ & 4.8 \\
\hline Manganese Dioxide & $\mathrm{MnO}_{2}$ & 3.1 \\
\hline Sodium Aluminosilicate & $\mathrm{Na}_{2} \mathrm{O} \cdot \mathrm{Al}_{2} \mathrm{O}_{3} \cdot\left(\mathrm{SiO}_{2}\right)_{2} \bullet 5 \mathrm{H}_{2} \mathrm{O}$ & 1.6 \\
\hline Sodium Oxalate & $\mathrm{Na}_{2} \mathrm{C}_{2} \mathrm{O}_{4}$ & 34.2 \\
\hline Sodium Carbonate Monohydrate & $\mathrm{Na}_{2} \mathrm{CO}_{3} \bullet \mathrm{H}_{2} \mathrm{O}$ & 32.3 \\
\hline Sodium Fluoride & $\mathrm{NaF}$ & 5.0 \\
\hline Sodium Sulfate Decahydrate & $\mathrm{Na}_{2} \mathrm{SO}_{4} \bullet 10 \mathrm{H}_{2} \mathrm{O}$ & 4.1 \\
\hline Sodium Phosphate Dodecahydrate & $\mathrm{Na}_{3} \mathrm{PO}_{4} \bullet 12 \mathrm{H}_{2} \mathrm{O}$ & 9.3 \\
\hline
\end{tabular}

Since these solids will be unwashed, particle size will change as washing proceeds. To insure a conservative basis testing filtration the particles should be less than 5 micrometers as similarly specified for the A envelope entrained solids.

\section{Miscellaneous Simulants}

Two miscellaneous simulants were created to support the pretreatment mixing study. Each simulant will be individually described.

\section{C-106 Caustic Leachate Simulant}

The C-106 caustic leach simulant is designed to represent the solution obtained when Hanford tank 241-C-106 solids are leached with a 3 molar sodium hydroxide solution at a temperature of at least 85 C. In the planned RPP-WTP process the solids from C-106 could be leached with 3 molar $\mathrm{NaOH}$ and the filtrate (leachate) transfer to the low activity waste feed tanks. The simulant is based on leaching studies of the C-106 solids. ${ }^{24}$ Since this supernate is similar but more dilute than the envelope A 
supernates, the supernate simulant strategy can be applied to this simulant. The analytical basis for the C-106 caustic leachate simulant is listed in Table 33.

Table 33 Analytical Basis for C-106 Caustic Leachate Simulant

\begin{tabular}{|c|c|c|}
\hline Component & Moles/Liter & mg/Liter \\
\hline Aluminum & $1.15 \mathrm{E}-01$ & 3100 \\
\hline Boron & $6.20 \mathrm{E}-03$ & 67 \\
\hline Chromium & $1.12 \mathrm{E}-03$ & 58 \\
\hline Copper & $4.41 \mathrm{E}-05$ & 3 \\
\hline Hydroxide & $2.70 \mathrm{E}+00$ & 45920 \\
\hline Iron & $1.79 \mathrm{E}-04$ & 10 \\
\hline Lead & $1.50 \mathrm{E}-04$ & 31 \\
\hline Silicon & $1.05 \mathrm{E}-02$ & 295 \\
\hline Sodium & $4.78 \mathrm{E}+00$ & 110000 \\
\hline Zirconium & $4.49 \mathrm{E}-05$ & 4 \\
\hline Nitrate & $5.40 \mathrm{E}-03$ & 335 \\
\hline Nitrite & $1.49 \mathrm{E}-01$ & 6850 \\
\hline Oxalate & $2.84 \mathrm{E}-02$ & 2500 \\
\hline Phosphate & $3.53 \mathrm{E}-03$ & 335 \\
\hline Sulfate & $1.87 \mathrm{E}-02$ & 1800 \\
\hline
\end{tabular}

Unlike the other supernates previously simulated, a measure of the carbonate level was not available since TIC was not reported for the leachate solution. The charge balance without carbonate being measured is very poor (1.67 moles/Liter excess positive charge compared to a total charge of 4.79 moles/liter). After confirming that the sludge in C-106 is high in carbonate, carbonate anion was used to balance the charge. ${ }^{25}$ The composition calculated for the C-106 caustic leachate is shown in Table 34 based upon a supernate density of $1.18 \mathrm{~g} / \mathrm{mL}$.

Table 34 C-106 Caustic Leachate Simulant Composition

\begin{tabular}{|c|c|c|}
\hline Compounds & Formula & Grams/Liter \\
\hline Boric Acid & $\mathrm{H}_{3} \mathrm{BO}_{3}$ & 0.383 \\
\hline Copper Nitrate & $\mathrm{Cu}\left(\mathrm{NO}_{3}\right)_{2} \bullet 2.5 \mathrm{H}_{2} \mathrm{O}$ & 0.010 \\
\hline Ferric Nitrate & $\mathrm{Fe}\left(\mathrm{NO}_{3}\right)_{3} \bullet 9 \mathrm{H}_{2} \mathrm{O}$ & 0.072 \\
\hline Lead nitrate & $\mathrm{Pb}\left(\mathrm{NO}_{3}\right)_{2}$ & 0.050 \\
\hline Zirconyl Nitrate & $\mathrm{ZrO}\left(\mathrm{NO}_{3}\right)_{2} \bullet \mathrm{xH}_{2} \mathrm{O}, \mathrm{x} \sim 1$ & 0.011 \\
\hline Sodium Chromate & $\mathrm{Na}_{2} \mathrm{CrO}_{4}$ & 0.181 \\
\hline Sodium Sulfate & $\mathrm{Na}_{2} \mathrm{SO}_{4}$ & 2.662 \\
\hline Aluminum Trihydroxide & $\mathrm{Al}_{(}(\mathrm{OH})_{3}$ & 8.962 \\
\hline Sodium Hydroxide & $\mathrm{NaOH}_{2}$ & 113.334 \\
\hline Sodium meta-silicate & $\mathrm{Na}_{2} \mathrm{SiO}_{3} \bullet 9 \mathrm{H}_{2} \mathrm{O}$ & 2.985 \\
\hline Sodium Oxalate & $\mathrm{Na}_{2} \mathrm{C}_{2} \mathrm{O}_{4}$ & 3.806 \\
\hline Sodium Phosphate & $\mathrm{Na}_{3} \mathrm{PO}_{4} \bullet 12 \mathrm{H}_{2} \mathrm{O}$ & 1.341 \\
\hline
\end{tabular}




\begin{tabular}{|c|c|c|}
\hline Compounds & Formula & Grams/Liter \\
\hline Sodium Carbonate & $\mathrm{Na}_{2} \mathrm{CO}_{3}$ & 88.502 \\
\hline Sodium Nitrate & $\mathrm{NaNO}_{3}$ & 0.373 \\
\hline Sodium Nitrite & $\mathrm{NaNO}_{2}$ & 10.274 \\
\hline Water & $\mathrm{H}_{2} \mathrm{O}$ & 944.55 \\
\hline
\end{tabular}

The analytical results for a test solution used in the pretreatment mixing study is shown as Table 35.

Table 35 Analytical Results for Simulated C-106 Caustic Leachate

\begin{tabular}{|c|c|c|c|}
\hline Component & Found, mg/L & Planned, mg/L & \% of Target \\
\hline $\mathrm{Al}$ & 2460 & 3100 & 79 \\
\hline $\mathrm{B}$ & 68 & 67 & 101 \\
\hline $\mathrm{Cr}$ & 49 & 58 & 85 \\
\hline $\mathrm{Na}$ & 105670 & 110000 & 96 \\
\hline $\mathrm{Pb}$ & 26 & 31 & 85 \\
\hline $\mathrm{Si}$ & 303 & 295 & 103 \\
\hline Nitrate & 241 & 335 & 72 \\
\hline Nitrite & 6589 & 6850 & 96 \\
\hline Oxalate & 698 & 2500 & 28 \\
\hline Phosphate & 303 & 335 & 90 \\
\hline Sulfate & 1570 & 1800 & 87 \\
\hline TIC & 3 & 10029 & 0 \\
\hline
\end{tabular}

The aluminum result is very close to the amount actually added based upon the purity of the hydrated aluminum trihydroxide used $(80 \%)$. The TIC appears to be a bad analytical result. The low level for the oxalate anion my be due to precipitation of sodium oxalate in the C-106 caustic leachate simulant. The leaching of the actual C-106 high-level waste sludge was conducted at $\sim 90 \mathrm{C}$, which increased the solubility of oxalate. Oxalate probably precipitated in the actual leachate after cooling to $\sim 25 \mathrm{C}$.

\section{AZ-102 Caustic Leachate Simulant}

The AZ-102 caustic leach simulant is designed to represent the solution obtained when Hanford tank 241-AZ-102 solids (envelope D material) are leached with a 3 molar sodium hydroxide solution. In the planned RPP-WTP, process the solids from AZ-102 could be leached with 3 molar $\mathrm{NaOH}$ and the filtrate (leachate) transferred to the low activity waste feed tanks. The simulant is based on leaching studies of the AZ-102 solids. ${ }^{26}$ Since this supernate is similar but more dilute than the envelope A supernates, the supernate simulant strategy can be applied to this simulant. The analytical basis for the AZ-102 caustic leachate simulant is listed in Table 36. 
Table 36 Basis for a AZ-102 Caustic Leachate Simulant

\begin{tabular}{|c|c|c|}
\hline Component & Moles/Liter & mg/Liter \\
\hline Aluminum & $5.71 \mathrm{E}-2$ & 1540 \\
\hline Chromium & $3.73 \mathrm{E}-03$ & 194 \\
\hline Molybdenum & $1.46 \mathrm{E}-04$ & 14 \\
\hline Potassium & $2.31 \mathrm{E}-02$ & 904 \\
\hline Sodium & $2.58 \mathrm{E}+00$ & 59200 \\
\hline Chloride & $6.21 \mathrm{E}-04$ & 22 \\
\hline Fluoride & $7.16 \mathrm{E}-03$ & 136 \\
\hline Nitrate & $9.58 \mathrm{E}-02$ & 5940 \\
\hline Nitrite & $1.72 \mathrm{E}-01$ & 7930 \\
\hline Phosphate & $6.25 \mathrm{E}-03$ & 594 \\
\hline Sulfate & $5.05 \mathrm{E}-02$ & 4850 \\
\hline TIC & $1.95 \mathrm{E}-01$ & 23.40 \\
\hline
\end{tabular}

The anion that was not measured in the reported AZ-102 caustic leachate is hydroxide. Therefore, hydroxide was used to provide the balance. The composition of the simulant based upon a supernate density of $1.095 \mathrm{~g} / \mathrm{mL}$ is shown in Table 37.

Table 37 AZ-102 Caustic Leachate Simulant Composition

\begin{tabular}{|c|c|c|}
\hline Compounds & Formula & Grams/Liter \\
\hline Potassium Nitrate & $\mathrm{KNO}_{3}$ & 2.308 \\
\hline Sodium Chloride & $\mathrm{NaCl}$ & 0.036 \\
\hline Sodium Chromate & $\mathrm{Na}_{2} \mathrm{CrO}_{4}$ & 0.604 \\
\hline Sodium Fluoride & $\mathrm{NaF}_{2}$ & 0.301 \\
\hline Sodium Sulfate & $\mathrm{Na}_{2} \mathrm{SO}_{4}$ & 7.172 \\
\hline Aluminum Trihydroxide & $\mathrm{Al}(\mathrm{OH})_{3}$ & 4.452 \\
\hline Sodium Hydroxide & $\mathrm{NaOH}$ & 72.203 \\
\hline Sodium Phosphate & $\mathrm{Na}_{3} \mathrm{PO}_{4} \bullet 12 \mathrm{H}_{2} \mathrm{O}$ & 2.377 \\
\hline Sodium Carbonate & $\mathrm{Na}_{2} \mathrm{CO}_{3}$ & 20.649 \\
\hline Sodium Nitrate & $\mathrm{NaNO}_{3}$ & 6.202 \\
\hline Sodium Nitrite & $\mathrm{NaNO}_{2}$ & 11.894 \\
\hline Water & $\mathrm{H}_{2} \mathrm{O}$ & 965.45 \\
\hline
\end{tabular}

The density of the AZ-102 leachate simulant test batch was $1.112 \mathrm{~g} / \mathrm{mL}$ and the weight percent total solids were $13.6 \%$. The analytical results for the AZ-102 leachate simulant is listed in Table 38. 
Table 38 Analytical Results for AZ-102 Caustic Leachate Simulant

\begin{tabular}{|c|c|c|c|}
\hline Component & Found & Planned & \% of Target \\
\hline $\mathrm{Al}$ & 1195 & 1540 & 78 \\
\hline $\mathrm{Cr}$ & 160 & 194 & 82 \\
\hline $\mathrm{K}$ & 920 & 904 & 102 \\
\hline $\mathrm{Mo}$ & 14 & 14 & 99 \\
\hline $\mathrm{Na}$ & 57070 & 59200 & 96 \\
\hline Chloride & 117 & 22 & 532 \\
\hline Fluoride & 100.0 & 136 & 74 \\
\hline Nitrate & 4515 & 5940 & 76 \\
\hline Nitrite & 7393 & 7930 & 93 \\
\hline Phosphate & 770 & 594 & 130 \\
\hline Sulfate & 4844 & 4850 & 100 \\
\hline TIC & $<200$ & 2340 & $<8.5$ \\
\hline
\end{tabular}

The aluminum result is very close to the amount actually added, based upon the purity of the hydrated aluminum trihydroxide used $(80 \%)$. The TIC and chloride appear to be bad analytical results.

\subsection{Conclusion/Summary}

The development of nonradioactive waste simulants to support the River Protection Project -Waste Treatment Plant bench and pilot-scale testing is crucial to the design of the facility. The report documents the simulants developed to support the SRTC programs and the strategies used to produce the simulants. The approved simulants for waste envelopes $\mathrm{A}, \mathrm{B}$, and $\mathrm{C}$ and the basis for their recipes were included. Additional simulants including sludge simulants, simulants of entrained solids, and simulants to support pretreatment mixing studies were discussed.

At the direction of the customer, the waste simulants were based upon specific waste characterization samples and did not involve averaging over multiple samples collected and analyzed at different times. The advantages and challenges of this approach were discussed along with recommendations for specific analyses that could improve the waste simulants. In general, the results of the A and B envelope simulants indicate that low concentrations of complexing agents may need to be analyzed for if trace metals are to be included in the simulant. For the $\mathrm{C}$ simulant, a method of analyzing for sodium gluconate either as the anion or as a derivatized organic compound is needed to provide a sounder basis for addition to the waste. At this point, it has definitely been established that some level of gluconate ion must be in the AN-107 waste to allow the level of soluble metals that are measured to be there.

The envelope A simulant that was developed as a part of this study and approved by the customer is based on tank 241-AN-105. Additional envelope A simulants prepared or calculated include simulants of tanks 241-AW-101, 241-AN-104, 241-AN-103 and a composite-dilution based simulant of 241- 
AN-105. The envelope B simulant that was approved by the customer was based on the Best Basis Inventory for Tank 241-AZ-101. An additional B envelope simulant that was developed is based on tank 241-AZ-102. Additional characterization work on the B supernates is recommended to measure the low level of complexing agents that must be present. Addition of these complexants should allow the trace species in the simulant to more accurately reflect the actual waste. The approved envelope $\mathrm{C}$ simulant is based on tank 241-AN-107. Entrained solids simulants were created for envelopes A and C based upon tanks 241-AN-105 and 241-AN-107 respectively.

The envelope D simulant was developed based upon tank 241-AZ-101 sludge that had not been caustic washed to reduce the aluminum level. Unlike the supernate simulants which assume that the supernate phase is homogeneous, the sludge simulant is based upon multiple samples and therefore make use of averaging. The AZ-101 sludge simulant is based on averaging two separate core samples due to the heterogeneous nature of the settled sludge. Initial results on particle size and rheology are promising. Work on the Envelope D simulant will be continued as part of the physical properties of the High Level Waste studies planned to support the vitrification process. 


\subsection{References}

1. C. A. Nash, Task Technical and Quality Assurance Plan for Simulant Development in Support of BNFL Part B, USDOE Report BNF-003-98-011, Rev. 0, Savannah River Site, Aiken SC 29808 (October 5, 1998).

2. D. Kaplan, D. McCabe, R. Eibling, Task Technical and Quality Assurance Plan in Support of BNFL Part B Mixing of Process Heels, Process Solutions, and Recycle Streams: Small-Scale Simulant, USDOE Report BNF-003-98-0079A, Savannah River Site, Aiken, SC 29808 (October 10, 1999).

3. W .L. Kubic, Jr., and G. Pillay, Data Reconciliation Study of Tank 241-AN-105 at the Hanford Site, LA-UR-97-3916 (September 1997).

4. C. D. Carlson, Speciation of Organic Carbon in Hanford Waste Storage Tanks: Part 1, PNNL-11480 UC-2030, Pacific Northwest National Laboratory, Richland, WA 99352 (February 1997).

5. R. A. Esch, Tank Waste Remediation System (TWRS) Privatization Private Contractor Samples Waste Envelope B Material Tank 241-AN-105 Summary Analytical Report, HNF-SD-WM-DP-218 Rev 1, Rust Federal Services of Hanford, Inc., Richland, WA 99352 (November 20, 1996).

6. D. L. Herting, Results of Dilution Studies with Waste from Tank 241-AN-105, HNF-SDWM-DTR-046 Rev. 0, Numatec Hanford Corporation, Richland, WA 99352 (October 10, 1997).

7. R. A. Esch, Tank Waste Remediation System (TWRS) Privatization Private Contractor Samples Waste Envelope A Material Tank 241-AW-101 Summary Analytical Report, WHC-SD-WM-DP-204 Rev 0, Rust Federal Services of Hanford, Inc., Richland, WA 99352 (November 20, 1996).

8. T. B. Calloway, Jr., Choi, A. S., Monson, P. R., Evaporation of Hanford Envelope B Simulant (AZ-101) Preliminary Report, USDOE Report BNF-003-98-0166 Rev. 1, Savannah River Site, Aiken SC 29808 (January 6, 2000).

9. D. I. Kaplan, R. E. Eibling, D. J. McCabe, Mixing of Process Heels, Process Solutions, and Recycle Streams: Small-Scale Simulant, WSRC-TR-2000-00307, SRT-RPP-200000016, Savannah River Site, Aiken, SC 29808 (January 3, 2001). 
10. D. L. Herting, Results of Dilution Studies with Waste from Tank 241-AN-105, HNF-SDWM-DTR-046, Rev. 0, Numatec Hanford Corporation, Richland, WA 99352 (October 10, 1997).

11. D. L. Herting, Results of Dilution Studies with Waste from Tank 241-AN-104, HNF3352, Rev. 0, Numatec Hanford Corporation, Richland, WA 99352 (September 1998).

12. M. W. Urie, J. J. Wagner, L. R Greenwood, O. T. Farmer, S. K. Fiskum, S. K. Ratner, C. Z. Soderquist, Inorganic and Radiochemical Analysis of AW-101 and AN-107 "Diluted Feed” Materials, PNWD-2463 Rev. 1, BNFL-RPT-003 Rev. 1, Pacific Northwest National Laboratory, Richland, WA 99352 (September 1999).

13. M. S. Hay, M. G. Bronikowski, N. M. Hassan, Chemical Characterization of an Envelope A Sample from Hanford Tank 241-AN-103, USDOE Report BNF-003-98-0248, Rev 0, Savannah River Site, Aiken, SC 29808 (June 13, 2000).

14. K. M. Hodgson, Tank Characterization Report for Double-Shell Tank 241-AZ-101, WHC-SD-WM-ER-410, Rev 0, Westinghouse Hanford Company, Richland, WA 99352 (July 26. 1995).

15. G. K. Patello, K. D. Weimers, TWRS Privatization Phase 1 Waste Characterization Data Evaluation for the Request for Proposal, PNNL-11109, Pacific Northwest National Laboratory, Richland, WA 99352 (September 1, 1996).

16. M. S. Hay, M. G. Bronikowski, Chemical Characterization of An Envelope B/D Sample from Hanford Tank 241-AZ-102, USDOE Report BNF-003-98-0249, Savannah River Site, Aiken, SC 29808 (August 2000).

17. W. J. Gray, M. E. Peterson, R. D. Scheele, J. M Tingey, Characterization of the First Core Sample of Neutralized Current Acid Waste From Double-Shell Tank 102-AZ, Pacific Northwest Laboratory, Richland WA 99352 January 1993.

18. R. A. Esch, Tank Waste Remediation System (TWRS) Privatization Private Contractor samples Waste Envelope C Material Tank 241-AN-107, HNF-SD-WM-DP-205, Rev. 1, Rust Federal Services of Hanford, Inc., Richland, WA 99352 (April 8, 1997).

19. J. A. Campbell, S. A. Clauss, K. E. Grant, V. Hoopes, G. M. Mong, R. Steele, D. Bellofatto, A. Sharma, Organic Tanks Safety Program Organic Analysis Progress Report FY 1997, PNNL-11738, UC-601, Pacific Northwest National Laboratory, Richland, WA 99352 (April 1998). 
20. E. K. Hansen, T. B. Calloway, Jr., R. E. Eibling, M. R. Poirier, Task Technical and Quality Assurance Plan for Mixing Envelope D Sludge with LAW Intermediate Products (Sr/TRU Precipitate and Cs/Tc Eluate) with and without Glass Formers, WSRC-RP2000-00731, SRT-RPP-2000-00002, Westinghouse Savannah River Company, Aiken, SC 29808 (September 18, 2000).

21. E. V. Morrey, J. M. Tingey, M. L. Elliott, Comparison of Simulants to Actual Neutralized Current Acid Waste: Process and Product Testing of Three NCAW Core Samples From Tanks 101-AZ and 102-AZ, PNNL-11025, UC-2030, Pacific Northwest National Laboratory, Richland, WA 99352 (October 1996).

22. R. L. Russell, H. D. Smith, Simulation and Characterization of a Hanford High-Level Waste Slurry, PNNL-11293, UC-2000, Pacific Northwest National Laboratory, Richland, WA 99352 (September 1996).

23. G. J. Lumetta, F. V. Hoopes, Washing of the AN-107 Entrained Solids, PNWD-2469, BNFL-RPT-007, Rev 0, Pacific Northwest National Laboratory, Richland WA 99352 (June 1999).

24. K. P Brooks, R. L. Myers, K. G. Rappe, Bench-Scale Enhanced Sludge Washing and Gravity Settling of Hanford Tank C-106 Sludge, PNNL-11432, Pacific Northwest National Laboratory, Richland WA 99352 (January 1997).

25. R. D. Scheiber, Tank Characterization Report for Single-Shell Tank 241-C-106, WHCSD-WM-ER-615, Rev.0, Westinghouse Hanford Company, Richland, WA 99352 (September 25, 1996).

26. D. L. Herting, Caustic Leaching of Sludge Sample from Tank 241-AZ-102, Letter 75764PCS95-086, Rev. 0, (September 29, 1995).

27. W. R. Wilmarth, R. E. Eibling, C. A. Nash, T. B. Edwards, Phase I and II Results from Sr and TRU Precipitation Tests, USDOE Report BNF-003-98-0180, Savannah River Site, Aiken, SC (September 15, 1999).

28. C. A. Nash, S. W. Rosencrance, B. W. Walker, W. R. Wilmarth, Investigation of Varied Strontium-Transuranic Precipitation Chemistries for Crossflow Filtration, USDOE Report BNF-003-98-0171, Savannah River Site, Aiken, SC 29808 (April 18, 2000).

29. L. M. Nelson, P.E. Lowe to M. Johnson, SRTC QA Program Plan for BNFL WFO Agreement, USDOE Report BNF-003-98-0008, Rev 1, Savannah River Site, Aiken, SC $29808(9 / 30 / 99)$. 


\section{Appendixes}




\section{Appendix A Envelope A Simulant Spreadsheets}

\section{Table 39 AN-105 Analytical Information}

\begin{tabular}{|c|c|c|c|c|c|c|c|c|c|c|}
\hline \multicolumn{11}{|c|}{ Tank AN105 Supernate Composition } \\
\hline & & & & & & & & & TOC & Source \\
\hline Component & $\begin{array}{l}\text { Molecular } \\
\text { weight }\end{array}$ & Concentration & Units & Concentration & Units & $\begin{array}{ll}\text { Moles } \\
\text { plus }\end{array}$ & $\begin{array}{ll}\text { Moles of } \\
\text { Minus }\end{array}$ & $\%$ Carbon & mg/Liter & \\
\hline Acetate & 59.04462 & 2070 & $\mathrm{mg} /$ Liter & $3.51 \mathrm{E}-02$ & M & & $3.51 \mathrm{E}-02$ & 40.68 & 842 & From AW-101 \\
\hline Aluminum & 26.98154 & 39700 & $\mathrm{mg} /$ Liter & $1.47 \mathrm{E}+00$ & M & & $1.47 \mathrm{E}+00$ & & & Part A AN105 Sample \\
\hline Ammonium & 18.03846 & 120 & $\mathrm{mg} /$ Liter & $6.65 \mathrm{E}-03$ & $\mathrm{M}$ & $6.65 \mathrm{E}-03$ & & & & From AW-101 \\
\hline Barium & 137.33 & & $\mathrm{mg} /$ Liter & $0.00 \mathrm{E}+00$ & $\mathrm{M}$ & $0.00 \mathrm{E}+00$ & & & & \\
\hline Boron & 10.81 & 51 & mg/Liter & 4.72E-03 & M & & $1.42 \mathrm{E}-02$ & & & DTR-046 report \\
\hline Bromide & 79.904 & & $\mathrm{mg} /$ Liter & $0.00 \mathrm{E}+00$ & $\mathrm{M}$ & & $0.00 \mathrm{E}+00$ & & & \\
\hline Cadmium & 112.41 & 3 & $\mathrm{mg} /$ Liter & $2.94 \mathrm{E}-05$ & M & $5.87 \mathrm{E}-05$ & & & & \\
\hline Calcium & 40.08 & 40 & $\mathrm{mg} /$ Liter & $9.98 \mathrm{E}-04$ & M & $2.00 \mathrm{E}-03$ & & & & Part A AN105 Sample \\
\hline Carbonate & 60.0092 & 12540 & $\mathrm{mg} /$ Liter & $2.09 \mathrm{E}-01$ & $\mathrm{M}$ & & $4.18 \mathrm{E}-01$ & & & Part A AN105 Sample \\
\hline Cerium & 140.12 & & $\mathrm{mg} /$ Liter & $0.00 \mathrm{E}+00$ & $\mathrm{M}$ & $0.00 \mathrm{E}+00$ & & & & \\
\hline Cesium & 132.9054 & 16 & $\mathrm{mg} /$ Liter & $1.22 \mathrm{E}-04$ & $\mathrm{M}$ & & & & & \\
\hline Chloride & 35.453 & 9090 & $\mathrm{mg} /$ Liter & $2.56 \mathrm{E}-01$ & M & & $2.56 \mathrm{E}-01$ & & & Part A AN105 Sample \\
\hline
\end{tabular}




\section{WESTINGHOUSE SAVANNAH RIVER COMPANY}

Hanford Waste Simulants Created to Support Research and Development on the River Protection Project - Waste Treatment Plant
Report: $\quad$ WSRC-TR-2000-00338

SRT-RPP-2000-00017

Revision (Date): $\quad 0(02 / 22 / 2001)$

Page: $\quad 63$ of 142

\begin{tabular}{|c|c|c|c|c|c|c|c|c|c|c|}
\hline \multicolumn{11}{|c|}{ Tank AN105 Supernate Composition } \\
\hline & & & & & & & & & TOC & Source \\
\hline Component & $\begin{array}{l}\text { Molecular } \\
\text { weight }\end{array}$ & Concentration & Units & Concentration & Units & $\begin{array}{ll}\text { Moles } & \text { of } \\
\text { plus }\end{array}$ & $\begin{array}{ll}\text { Moles of } \\
\text { Minus }\end{array}$ & $\%$ Carbon & mg/Liter & \\
\hline Chromium & 51.996 & 1350 & $\mathrm{mg} /$ Liter & $2.60 \mathrm{E}-02$ & $\mathrm{M}$ & & $5.19 \mathrm{E}-02$ & & & DTR-046 report \\
\hline Copper & 63.546 & & $\mathrm{mg} /$ Liter & $0.00 \mathrm{E}+00$ & M & $0.00 \mathrm{E}+00$ & & & & \\
\hline Ethylenediaminetetraacetic acid & 288.20824 & & $\mathrm{mg} /$ Liter & $0.00 \mathrm{E}+00$ & $\mathrm{M}$ & & $0.00 \mathrm{E}+00$ & 41.67 & 0 & \\
\hline Fluoride & 18.9984 & 190 & $\mathrm{mg} /$ Liter & $1.00 \mathrm{E}-02$ & $\mathrm{M}$ & & $1.00 \mathrm{E}-02$ & & & less than from DTR-04 \\
\hline Formate & 45.01774 & 2880 & $\mathrm{mg} /$ Liter & $6.40 \mathrm{E}-02$ & $\mathrm{M}$ & & $6.40 \mathrm{E}-02$ & 26.68 & 768 & From AW-101 \\
\hline Glycolate & 75.04206 & 1150 & $\mathrm{mg} /$ Liter & $1.53 \mathrm{E}-02$ & $\mathrm{M}$ & & $1.53 \mathrm{E}-02$ & 32.01 & 368 & From AW-101 \\
\hline Hydroxide & 17.00734 & 58100 & $\mathrm{mg} /$ Liter & $3.42 \mathrm{E}+00$ & $\mathrm{M}$ & & $3.42 \mathrm{E}+00$ & & & Part A AN105 Sample \\
\hline Iron & 55.847 & & $\mathrm{mg} /$ Liter & $0.00 \mathrm{E}+00$ & $\mathrm{M}$ & $0.00 \mathrm{E}+00$ & & & & \\
\hline Lanthanum & 138.9055 & & $\mathrm{mg} /$ Liter & $0.00 \mathrm{E}+00$ & $\mathrm{M}$ & $0.00 \mathrm{E}+00$ & & & & \\
\hline Lead & 207.2 & 53 & $\mathrm{mg} /$ Liter & $2.56 \mathrm{E}-04$ & $\mathrm{M}$ & $5.12 \mathrm{E}-04$ & & & & Part A AN105 Sample \\
\hline Magnesium & 24.305 & 5 & $\mathrm{mg} /$ Liter & $2.22 \mathrm{E}-04$ & $\mathrm{M}$ & 4.44E-04 & & & & Part A AN105 Sample \\
\hline Manganese & 54.938 & & $\mathrm{mg} /$ Liter & $0.00 \mathrm{E}+00$ & $\mathrm{M}$ & $0.00 \mathrm{E}+00$ & & & & \\
\hline Molybdenum & 95.94 & 82 & $\mathrm{mg} /$ Liter & $8.55 \mathrm{E}-04$ & $\mathrm{M}$ & & $1.71 \mathrm{E}-03$ & & & DTR-046 report \\
\hline Neodymium & 144.24 & & $\mathrm{mg} /$ Liter & $0.00 \mathrm{E}+00$ & M & $0.00 \mathrm{E}+00$ & & & & \\
\hline
\end{tabular}




\section{WESTINGHOUSE SAVANNAH RIVER COMPANY}

Hanford Waste Simulants Created to Support Research and Development on the River Protection Project - Waste Treatment Plant
Report: $\quad$ WSRC-TR-2000-00338

SRT-RPP-2000-00017

Revision (Date): $\quad 0(02 / 22 / 2001)$

Page: $\quad 64$ of 142

\begin{tabular}{|c|c|c|c|c|c|c|c|c|c|c|}
\hline Tank AN105 Supernate Composi & & & & & & & & & & \\
\hline & & & & & & & & & TOC & Source \\
\hline Component & $\begin{array}{l}\text { Molecular } \\
\text { weight }\end{array}$ & Concentration & Units & Concentration & Units & \begin{tabular}{ll|l} 
Moles & of & 1 \\
plus & & 1
\end{tabular} & $\begin{array}{l}\text { Moles of } \\
\text { Minus }\end{array}$ & $\%$ Carbon & mg/Liter & \\
\hline $\begin{array}{l}\text { n-Hydroxyethylenediaminetriacetic } \\
\text { acid }\end{array}$ & 275.23618 & & $\mathrm{mg} /$ Liter & $0.00 \mathrm{E}+00$ & M & & $0.00 \mathrm{E}+00$ & 43.64 & 0 & \\
\hline Nickel & 58.69 & & $\mathrm{mg} /$ Liter & $0.00 \mathrm{E}+00$ & $\mathrm{M}$ & $0.00 \mathrm{E}+00$ & & & & \\
\hline Nitrate & 62.0049 & 165000 & $\mathrm{mg} /$ Liter & $2.66 \mathrm{E}+00$ & $\mathrm{M}$ & & $2.66 \mathrm{E}+00$ & & & Part A AN105 Sample \\
\hline Nitrite & 46.0055 & 111000 & $\mathrm{mg} /$ Liter & $2.41 \mathrm{E}+00$ & $\mathrm{M}$ & & $2.41 \mathrm{E}+00$ & & & Part A AN105 Sample \\
\hline Oxalate & 88.0196 & 610 & $\mathrm{mg} /$ Liter & $6.93 \mathrm{E}-03$ & $\mathrm{M}$ & & $1.39 \mathrm{E}-02$ & 27.29 & 166 & From AW-101 \\
\hline Phosphate & 94.97136 & 570 & $\mathrm{mg} /$ Liter & $6.00 \mathrm{E}-03$ & $\mathrm{M}$ & & $1.80 \mathrm{E}-02$ & & & Part A AN105 Sample \\
\hline Potassium & 39.0983 & 7500 & $\mathrm{mg} /$ Liter & $1.92 \mathrm{E}-01$ & $\mathrm{M}$ & $1.92 \mathrm{E}-01$ & & & & DTR-046 report \\
\hline Selenium & 78.96 & 1 & $\mathrm{mg} /$ Liter & $1.25 \mathrm{E}-05$ & $\mathrm{M}$ & & $2.51 \mathrm{E}-05$ & & & \\
\hline Silicon & 28.0855 & 211 & $\mathrm{mg} /$ Liter & $7.51 \mathrm{E}-03$ & $\mathrm{M}$ & & $1.50 \mathrm{E}-02$ & & & DTR-046 report \\
\hline Silver & 107.8682 & 16 & mg/Liter & $1.51 \mathrm{E}-04$ & M & $1.51 \mathrm{E}-04$ & & & & \\
\hline Sodium & 22.9898 & 233000 & $\mathrm{mg} /$ Liter & $1.01 \mathrm{E}+01$ & $\mathrm{M}$ & $1.01 \mathrm{E}+01$ & & & & Part A AN105 Sample \\
\hline Sulfate & 96.0576 & 771 & $\mathrm{mg} /$ Liter & $8.03 \mathrm{E}-03$ & $\mathrm{M}$ & & $1.61 \mathrm{E}-02$ & & & Part A AN105 Sample \\
\hline Tin & & 22 & $\mathrm{mg} /$ Liter & $1.83 \mathrm{E}-04$ & $\mathrm{M}$ & & & & & \\
\hline TIC & 12.011 & 2510 & $\mathrm{mg} /$ Liter & 2.09E-01 & M & & & & & Part A AN105 Sample \\
\hline
\end{tabular}




\section{WESTINGHOUSE SAVANNAH RIVER COMPANY}

Hanford Waste Simulants Created to Support Research and Development on the River Protection Project - Waste Treatment Plant
Report: $\quad$ WSRC-TR-2000-00338

SRT-RPP-2000-00017

Revision (Date): $\quad 0(02 / 22 / 2001)$

Page: $\quad 65$ of 142

\begin{tabular}{|c|c|c|c|c|c|c|c|c|c|c|c|}
\hline \multicolumn{12}{|c|}{ Tank AN105 Supernate Composition } \\
\hline & & & & & & & & & & TOC & Source \\
\hline Component & $\begin{array}{l}\text { Molecular } \\
\text { weight }\end{array}$ & Concentration & Units & Concentration & Units & & $\mid \begin{array}{ll}\text { Moles } & \text { of } \\
\text { plus } & \end{array}$ & $\mid \begin{array}{ll}\text { Moles of } \\
\text { Minus }\end{array}$ & $\%$ Carbon & mg/Liter & \\
\hline TOC & & 3590 & $\mathrm{mg} /$ Liter & 3.59 & $\mathrm{~g} / \mathrm{L}$ & & & & & & Part A AN105 Sample \\
\hline Uranium & & & $\mathrm{mg} /$ Liter & $0.00 \mathrm{E}+00$ & $\mathrm{ug} / \mathrm{mL}$ & & & & & & \\
\hline Zinc & 65.38 & 10 & $\mathrm{mg} /$ Liter & $1.54 \mathrm{E}-04$ & $\mathrm{M}$ & & $3.09 \mathrm{E}-04$ & & & & \\
\hline Zirconium & 91.22 & & $\mathrm{mg} /$ Liter & $0.00 \mathrm{E}+00$ & M & & $0.00 \mathrm{E}+00$ & & & & \\
\hline & & & & & & Total & 10.34 & $1.09 \mathrm{E}+01$ & Moles/Liter & & \\
\hline & & & & & & Balance & & $5.54 \mathrm{E}-01$ & & & \\
\hline \multicolumn{12}{|c|}{ Additional Organics(based upon PNNL Report on FY1997 Results) } \\
\hline Nitrilotriacetic Acid & 188.11618 & & $\mathrm{mg} /$ Liter & $0.00 \mathrm{E}+00$ & $\mathrm{M}$ & & & $0.00 \mathrm{E}+00$ & Moles/Liter & & \\
\hline Citric Acid & 189.09618 & & $\mathrm{mg} /$ Liter & $0.00 \mathrm{E}+00$ & M & & & $0.00 \mathrm{E}+00$ & Moles/Liter & & \\
\hline Iminodiacetic Acid & 131.08412 & & $\mathrm{mg} /$ Liter & $0.00 \mathrm{E}+00$ & M & & & $0.00 \mathrm{E}+00$ & Moles/Liter & & \\
\hline \multicolumn{12}{|l|}{ Source } \\
\hline Sodium Gluconate & 218.14 & 0 & $\mathrm{mg} /$ Liter & & M & & $0.00 \mathrm{E}+00$ & 0.0 & & & \\
\hline & & & & & & Total & 10.34 & 10.89 & & 1979 & mg/Liter \\
\hline & & & & & & Short & 0.55 & & & 1611 & $\mathrm{mg} /$ Liter \\
\hline
\end{tabular}




\section{WESTINGHOUSE SAVANNAH RIVER COMPANY}

Hanford Waste Simulants Created to Support Research and Development on the River Protection Project - Waste Treatment Plant
Report: $\quad$ WSRC-TR-2000-00338 SRT-RPP-2000-00017

\section{Revision (Date): $\quad 0(02 / 22 / 2001)$}

\begin{tabular}{|c|c|c|c|c|c|c|c|c|c|c|}
\hline \multicolumn{11}{|c|}{ Tank AN105 Supernate Composition } \\
\hline & & & & & & & & & TOC & Source \\
\hline Component & $\begin{array}{l}\text { Molecular } \\
\text { weight }\end{array}$ & Concentration & Units & Concentration & Units & $\begin{array}{ll}\text { Moles } & \text { of } \\
\text { plus } & \end{array}$ & $\begin{array}{ll}\text { Moles } & \text { of } \\
\text { Minus } & \end{array} \mid$ & $\%$ Carbon & mg/Liter & \\
\hline Density (average) & & 1.2 & & & & & & & & \\
\hline
\end{tabular}




\section{Table 40 Compound Calculations for AN-105 Simulant}

\begin{tabular}{|c|c|c|c|c|c|c|c|c|c|}
\hline Measured TOC & 3.6 & & & & & & & & \\
\hline & & & & & & & Formula Weight & Mass Needed & Mass of $\mathrm{H2O}$ \\
\hline Compounds & Moles & Nitrate Moles & Contains [Na] & Moles of Na Needed & Wt \% Carbon & Formula & grams & grams & grams \\
\hline Aluminum Trihydroxide & $1.47 \mathrm{E}+00$ & & & $1.47 \mathrm{E}+00$ & & $\mathrm{Al}(\mathrm{OH}) 3$ & 78 & 114.767 & \\
\hline Ammonium Acetate & 6.65E-03 & & & & 31.2 & $\mathrm{CH} 3 \mathrm{COONH} 4$ & 77.08 & 0.513 & \\
\hline Barium Nitrate & $0.00 \mathrm{E}+00$ & $0.00 \mathrm{E}+00$ & & & & $\mathrm{Ba}(\mathrm{NO} 3) 2$ & 261.35 & 0.000 & \\
\hline Boric Acid & $4.72 \mathrm{E}-03$ & & & $1.42 \mathrm{E}-02$ & & $\mathrm{H} 3 \mathrm{BO} 3$ & 61.83 & 0.292 & \\
\hline Cadmium Nitrate & $2.94 \mathrm{E}-05$ & $5.87 \mathrm{E}-05$ & & & & $\mathrm{Cd}(\mathrm{NO} 3) 2.4 \mathrm{H} 2 \mathrm{O}$ & 308.47 & 0.009 & $2.11 \mathrm{E}-03$ \\
\hline Calcium Nitrate & $9.98 \mathrm{E}-04$ & $2.00 \mathrm{E}-03$ & & & & $\mathrm{Ca}(\mathrm{NO} 3) 2.4 \mathrm{H} 2 \mathrm{O}$ & 236.15 & 0.236 & 7.19E-02 \\
\hline Cerium Nitrate & $0.00 \mathrm{E}+00$ & $0.00 \mathrm{E}+00$ & & & & $\mathrm{Ce}(\mathrm{NO} 3) 3.6 \mathrm{H} 2 \mathrm{O}$ & 434.23 & 0.000 & $0.00 \mathrm{E}+00$ \\
\hline Cesium Nitrate & $1.22 \mathrm{E}-04$ & $1.22 \mathrm{E}-04$ & & & & CsNO3 & 194.91 & 0.024 & \\
\hline Sodium Chromate & $2.60 \mathrm{E}-02$ & & $5.19 \mathrm{E}-02$ & & & $\mathrm{Na} 2 \mathrm{CrO} 4$ & 161.97 & 4.205 & \\
\hline Copper Nitrate & $0.00 \mathrm{E}+00$ & $0.00 \mathrm{E}+00$ & & & & $\mathrm{Cu}(\mathrm{NO} 3) 2.2 .5 \mathrm{H} 2 \mathrm{O}$ & 232.59 & 0.000 & $0.00 \mathrm{E}+00$ \\
\hline $\begin{array}{l}\text { Ethylenediaminetetraacetic } \\
\text { acid }\end{array}$ & $0.00 \mathrm{E}+00$ & & $0.00 \mathrm{E}+00$ & $0.00 \mathrm{E}+00$ & 32.3 & Na2EDTA.2H2O & 372.24 & 0.000 & \\
\hline Ferric Nitrate & $0.00 \mathrm{E}+00$ & $0.00 \mathrm{E}+00$ & & & & $\mathrm{Fe}(\mathrm{NO} 3) 3.9 \mathrm{H} 2 \mathrm{O}$ & 404 & 0.000 & $0.00 \mathrm{E}+00$ \\
\hline
\end{tabular}




\section{WESTINGHOUSE SAVANNAH RIVER COMPANY}

Hanford Waste Simulants Created to Support Research and

Development on the River Protection Project - Waste Treatment Plant
Report: $\quad$ WSRC-TR-2000-00338

SRT-RPP-2000-00017

Revision (Date): $\quad 0(02 / 22 / 2001)$

Page: $\quad 68$ of 142

\begin{tabular}{|c|c|c|c|c|c|c|c|c|c|}
\hline Measured TOC & 3.6 & & & & & & & & \\
\hline & & & & & & & Formula Weight & Mass Needed & Mass of $\mathrm{H2O}$ \\
\hline Compounds & Moles & Nitrate Moles & Contains [Na] & Moles of Na Needed & Wt \% Carbon & Formula & grams & grams & grams \\
\hline Lanthanum Nitrate & $0.00 \mathrm{E}+00$ & $0.00 \mathrm{E}+00$ & & & & $\mathrm{La}(\mathrm{NO} 3) 3.6 \mathrm{H} 2 \mathrm{O}$ & 433.03 & 0.000 & $0.00 \mathrm{E}+00$ \\
\hline Lead nitrate & $2.56 \mathrm{E}-04$ & $5.12 \mathrm{E}-04$ & & & & $\mathrm{~Pb}(\mathrm{NO} 3) 2$ & 331.2 & 0.085 & \\
\hline Magnesium Nitrate & $2.22 \mathrm{E}-04$ & 4.44E-04 & & & & $\mathrm{Mg}(\mathrm{NO} 3) 2.6 \mathrm{H} 2 \mathrm{O}$ & 256.41 & 0.057 & $2.40 \mathrm{E}-02$ \\
\hline Manganous Chloride & $0.00 \mathrm{E}+00$ & & & & & $\mathrm{MnCl} 2.4 \mathrm{H} 2 \mathrm{O}$ & 197.9 & 0.000 & $0.00 \mathrm{E}+00$ \\
\hline Potassium Molybdate & $8.55 \mathrm{E}-04$ & & & & & $\mathrm{~K} 2 \mathrm{MoO} 4$ & 238.14 & 0.204 & \\
\hline Neodymium Nitrate & $0.00 \mathrm{E}+00$ & $0.00 \mathrm{E}+00$ & & & & $\mathrm{Nd}(\mathrm{NO} 3) 3.6 \mathrm{H} 2 \mathrm{O}$ & 438.35 & 0.000 & $0.00 \mathrm{E}+00$ \\
\hline $\begin{array}{l}\text { n- } \\
\text { Hydroxyethylenediaminetri } \\
\text { acetic acid }\end{array}$ & $0.00 \mathrm{E}+00$ & & & 0 & 43.2 & HEDTA & 278.26 & 0.000 & \\
\hline Nickel Nitrate & $0.00 \mathrm{E}+00$ & $0.00 \mathrm{E}+00$ & & & & $\mathrm{Ni}(\mathrm{NO} 3) 2.6 \mathrm{H} 2 \mathrm{O}$ & 290.81 & 0.000 & $0.00 \mathrm{E}+00$ \\
\hline Potassium Nitrate & $1.90 \mathrm{E}-01$ & $1.90 \mathrm{E}-01$ & & & & KNO3 & 101.1 & 19.221 & \\
\hline Selenium dioxide & $1.25 \mathrm{E}-05$ & & & $2.51 \mathrm{E}-05$ & & $\mathrm{SeO} 2$ & 110.96 & 0.001 & \\
\hline Sodium meta-silicate & $7.51 \mathrm{E}-03$ & & $1.50 \mathrm{E}-02$ & & & $\mathrm{Na} 2 \mathrm{SiO} 3.9 \mathrm{H} 2 \mathrm{O}$ & 284.2 & 2.135 & $1.22 \mathrm{E}+00$ \\
\hline Silver Nitrate & $1.51 \mathrm{E}-04$ & $1.51 \mathrm{E}-04$ & & & & $\mathrm{AgNO} 3$ & 169.87 & 0.026 & \\
\hline Strontium Nitrate & & $0.00 \mathrm{E}+00$ & & & & $\mathrm{Sr}(\mathrm{NO} 3) 2$ & 211.63 & 0.000 & \\
\hline Zinc Nitrate & $1.54 \mathrm{E}-04$ & $3.09 \mathrm{E}-04$ & & & & $\mathrm{Zn}(\mathrm{NO} 3) 2.6 \mathrm{H} 2 \mathrm{O}$ & 297.47 & 0.046 & 0.016684001 \\
\hline
\end{tabular}




\section{WESTINGHOUSE SAVANNAH RIVER COMPANY}

Hanford Waste Simulants Created to Support Research and

Development on the River Protection Project - Waste Treatment Plant
Report: $\quad$ WSRC-TR-2000-00338

SRT-RPP-2000-00017

Revision (Date): $\quad 0(02 / 22 / 2001)$

Page: $\quad 69$ of 142

\begin{tabular}{|c|c|c|c|c|c|c|c|c|c|}
\hline Measured TOC & 3.6 & & & & & & & & \\
\hline & & & & & & & Formula Weight & Mass Needed & Mass of $\mathrm{H2O}$ \\
\hline Compounds & Moles & Nitrate Moles & Contains [Na] & Moles of Na Needed & Wt \% Carbon & Formula & grams & grams & grams \\
\hline Zirconyl Nitrate & $0.00 \mathrm{E}+00$ & 0 & & & & & 249.23 & 0.000 & 0 \\
\hline Sodium Acetate & $2.84 \mathrm{E}-02$ & & $2.84 \mathrm{E}-02$ & & 17.7 & $\mathrm{NaCH} 3 \mathrm{COO} .3 \mathrm{H} 2 \mathrm{O}$ & 136.08 & 3.865 & $1.53 \mathrm{E}+00$ \\
\hline Sodium Bromide & $0.00 \mathrm{E}+00$ & & $0.00 \mathrm{E}+00$ & & & $\mathrm{NaBr}$ & 102.89 & 0.000 & \\
\hline Sodium Carbonate & $2.09 \mathrm{E}-01$ & & $4.18 \mathrm{E}-01$ & & & $\mathrm{Na} 2 \mathrm{CO} 3$ & 105.99 & 22.149 & \\
\hline Sodium Chloride & $2.56 \mathrm{E}-01$ & & $2.56 \mathrm{E}-01$ & & & $\mathrm{NaCl}$ & 58.44 & 14.984 & \\
\hline Sodium Fluoride & $1.00 \mathrm{E}-02$ & & $1.00 \mathrm{E}-02$ & & & $\mathrm{NaF}$ & 41.99 & 0.420 & \\
\hline Sodium Formate & $6.40 \mathrm{E}-02$ & & $6.40 \mathrm{E}-02$ & & 17.7 & $\mathrm{HCOONa}$ & 68.01 & 4.351 & \\
\hline Glycolic Acid & $1.53 \mathrm{E}-02$ & & & $1.53 \mathrm{E}-02$ & 31.6 & $\begin{array}{l}\mathrm{HOCH} 2 \mathrm{COOH}, \quad 70 \\
\text { wt } \%\end{array}$ & 76.05 & 1.665 & \\
\hline Sodium Nitrite & $2.41 \mathrm{E}+00$ & & $2.41 \mathrm{E}+00$ & & & $\mathrm{NaNO} 2$ & 69 & 166.480 & \\
\hline Sodium Oxalate & $6.93 \mathrm{E}-03$ & & $1.39 \mathrm{E}-02$ & & 17.9 & $\mathrm{Na} 2 \mathrm{C} 2 \mathrm{O} 4$ & 134 & 0.929 & \\
\hline Sodium Phosphate & $6.00 \mathrm{E}-03$ & & $1.80 \mathrm{E}-02$ & & & $\mathrm{Na} 3 \mathrm{PO} 4.12 \mathrm{H} 2 \mathrm{O}$ & 380.12 & 2.281 & $1.30 \mathrm{E}+00$ \\
\hline Sodium Sulfate & $8.03 \mathrm{E}-03$ & & $1.61 \mathrm{E}-02$ & & & $\mathrm{Na} 2 \mathrm{SO} 4$ & 142.04 & 1.140 & \\
\hline Sodium Nitrate & $2.47 \mathrm{E}+00$ & $2.47 \mathrm{E}+00$ & $2.47 \mathrm{E}+00$ & & & $\mathrm{NaNO} 3$ & 84.99 & 209.702 & \\
\hline Sodium Hydroxide & $4.92 \mathrm{E}+00$ & & $4.92 \mathrm{E}+00$ & & & $\mathrm{NaOH}$ & 40 & 196.682 & \\
\hline
\end{tabular}




\section{WESTINGHOUSE SAVANNAH RIVER COMPANY}

Hanford Waste Simulants Created to Support Research and Development on the River Protection Project - Waste Treatment Plant
Report: $\quad$ WSRC-TR-2000-00338

SRT-RPP-2000-00017

Revision (Date): $\quad 0(02 / 22 / 2001)$

\begin{tabular}{|c|c|c|c|c|c|c|c|c|c|}
\hline Measured TOC & 3.6 & & & & & & & & \\
\hline & & & & & & & Formula Weight & Mass Needed & Mass of $\mathrm{H} 2 \mathrm{O}$ \\
\hline Compounds & Moles & Nitrate Moles & Contains [Na] & Moles of Na Needed & Wt \% Carbon & Formula & grams & grams & grams \\
\hline Totals & & $2.66 \mathrm{E}+00$ & 10.7 & & & & & 766.468 & $4.16 \mathrm{E}+00$ \\
\hline Target & & $2.66 \mathrm{E}+00$ & 10.1 & & & & & & \\
\hline & & $0.00 \mathrm{E}+00$ & -0.55 & & & & & & \\
\hline $\begin{array}{l}\text { Sodium Hydroxide Charge } \\
\text { balance }\end{array}$ & $4.36 \mathrm{E}+00$ & & & & & & & & \\
\hline Difference & $-5.54 \mathrm{E}-01$ & & & & & & & & \\
\hline Measured Density & 1.44 & grams $/ \mathrm{mL}$ & & & & & & & \\
\hline Total Solution Mass & 1440 & grams $/ \mathrm{mL}$ & & & & & & & \\
\hline$\%$ Solids & $5.294 \mathrm{E}+01$ & & & & & & & & \\
\hline Mass of Water & $6.74 \mathrm{E}+02$ & grams & & & & & & & \\
\hline
\end{tabular}




\section{Table 41 AN-105 Simulant Recipe}

\begin{tabular}{|c|c|c|c|}
\hline Complete Envelope & & & \\
\hline Volume of Feed & & 1000 & $\mathrm{~mL}$ \\
\hline In a tared & 1000 & $\begin{array}{ccc}\mathrm{mL} & \text { Volumetric } \\
\mathrm{add} & \end{array}$ & \\
\hline & grams & Actual Wt, grams & \\
\hline Water & 200 & & \\
\hline Transition Metals a & & & \\
\hline Compounds & Formula & Mass Needed & Actual Wt, grams \\
\hline Boric Acid & $\mathrm{H} 3 \mathrm{BO} 3$ & 0.292 & \\
\hline Cadmium Nitrate & $\mathrm{Cd}(\mathrm{NO} 3) 2.4 \mathrm{H} 2 \mathrm{O}$ & 0.009 & \\
\hline Calcium Nitrate & $\mathrm{Ca}(\mathrm{NO} 3) 2.4 \mathrm{H} 2 \mathrm{O}$ & 0.236 & \\
\hline Cesium Nitrate & $\mathrm{CsNO} 3$ & 0.024 & \\
\hline Lead nitrate & $\mathrm{Pb}(\mathrm{NO} 3) 2$ & 0.085 & \\
\hline Magnesium Nitrate & $\mathrm{Mg}(\mathrm{NO} 3) 2.6 \mathrm{H} 2 \mathrm{O}$ & 0.057 & \\
\hline Potassium Nitrate & KNO3 & 19.221 & \\
\hline Silver Nitrate & $\mathrm{AgNO} 3$ & 0.026 & \\
\hline Zinc Nitrate & $\mathrm{Zn}(\mathrm{NO} 3) 2.6 \mathrm{H} 2 \mathrm{O}$ & 0.046 & \\
\hline Glycolic Acid & $\mathrm{HOCH} 2 \mathrm{COOH}, 70 \mathrm{wt} \%$ & 1.665 & \\
\hline
\end{tabular}


WESTINGHOUSE SAVANNAH RIVER COMPANY

Hanford Waste Simulants Created to Support Research and Development on the River Protection Project - Waste Treatment Plant
Report:

WSRC-TR-2000-00338

SRT-RPP-2000-00017

Revision (Date): $\quad 0(02 / 22 / 2001)$

Page:

\begin{tabular}{|c|c|c|c|}
\hline Sodium Chloride & $\mathrm{NaCl}$ & 14.984 & \\
\hline Sodium Fluoride & $\mathrm{NaF}$ & 0.420 & \\
\hline Sodium Chromate & $\mathrm{Na} 2 \mathrm{CrO} 4$ & 4.205 & \\
\hline Sodium Sulfate & $\mathrm{Na} 2 \mathrm{SO} 4$ & 1.140 & \\
\hline Potassium Molybdate & $\mathrm{K} 2 \mathrm{MoO} 4$ & 0.204 & \\
\hline Ammonium Acetate & $\mathrm{CH} 3 \mathrm{COONH} 4$ & 0.513 & \\
\hline \multicolumn{4}{|c|}{ In a separate container mix the following } \\
\hline Compounds & Formula & Mass Needed & Actual Wt, grams \\
\hline Aluminum Trihydroxide & $\mathrm{Al}(\mathrm{OH}) 3$ & 114.77 & \\
\hline Sodium Hydroxide & $\mathrm{NaOH}$ & 196.68 & \\
\hline Selenium dioxide & $\mathrm{SeO} 2$ & 0.001 & \\
\hline Sodium meta-silicate & $\mathrm{Na} 2 \mathrm{SiO} 3.9 \mathrm{H} 2 \mathrm{O}$ & 2.135 & \\
\hline Sodium Acetate & $\mathrm{NaCH} 3 \mathrm{COO} .3 \mathrm{H} 2 \mathrm{O}$ & 3.865 & \\
\hline Sodium Formate & $\mathrm{HCOONa}$ & 4.351 & \\
\hline Sodium Oxalate & $\mathrm{Na} 2 \mathrm{C} 2 \mathrm{O} 4$ & 0.929 & \\
\hline Sodium Phosphate & $\mathrm{Na} 3 \mathrm{PO} 4.12 \mathrm{H} 2 \mathrm{O}$ & 2.281 & \\
\hline Add & grams & Actual Wt, grams & \\
\hline Water & & & \\
\hline Mix thoroughly. Then a & volumetric flask. & & \\
\hline
\end{tabular}


Hanford Waste Simulants Created to Support Research and Revision (Date): SRT-RPP-2000-00017 Development on the River Protection Project - Waste Treatment Plant Page:

\begin{tabular}{|c|c|c|c|}
\hline Add & Formula & Mass Needed & Actual Wt, grams \\
\hline Sodium Carbonate & $\mathrm{Na} 2 \mathrm{CO} 3$ & 22.149 & \\
\hline Mix thoroughly. & & & \\
\hline Add & Formula & Mass Needed & Actual Wt, grams \\
\hline Sodium Nitrate & $\mathrm{NaNO} 3$ & 209.70 & \\
\hline Sodium Nitrite & $\mathrm{NaNO} 2$ & 166.48 & \\
\hline Mix thoroughly. & & & \\
\hline Mix thoroughly and dilute to the marl & & & \\
\hline Record Final Weight & & grams & \\
\hline The final addition of water would be & & 173.53 & grams based upon \\
\hline a density of $1.44 \mathrm{~g} / \mathrm{mL}$. & & & \\
\hline
\end{tabular}




\section{Appendix B Envelope B Simulant Spreadsheets}

Table 42 Best Basis Inventory for Tank 241-AZ-101 used in Envelope B Simulant

\begin{tabular}{|c|c|c|}
\hline \multicolumn{3}{|c|}{$\begin{array}{l}\text { Inventory based on dst inventory calculations from both } \\
\text { nomalized TRAC or BBI as of } 10 / 1 / 98 \text { where available. File is }\end{array}$} \\
\hline dst_inv_99.csv & & \\
\hline TANK & AZ-101 & Concentration \\
\hline SOLUBLE & AZ-101 & mg/Liter \\
\hline $106-\mathrm{Ru}$ & $0.00 \mathrm{E}+00$ & 0.0 \\
\hline $113 m-C d$ & $0.00 \mathrm{E}+00$ & 0.0 \\
\hline $125-\mathrm{Sb}$ & $0.00 \mathrm{E}+00$ & 0.0 \\
\hline 126-Sn & $0.00 \mathrm{E}+00$ & 0.0 \\
\hline 129-I & $0.00 \mathrm{E}+00$ & 0.0 \\
\hline 134-Cs & $0.00 \mathrm{E}+00$ & 0.0 \\
\hline $137 \mathrm{~m}-\mathrm{Ba}$ & $0.00 \mathrm{E}+00$ & 0.0 \\
\hline 137-Cs & $6.35 \mathrm{E}+01$ & 21.0 \\
\hline 14-C & $0.00 \mathrm{E}+00$ & 0.0 \\
\hline 151-Sm & $0.00 \mathrm{E}+00$ & 0.0 \\
\hline 152-Eu & $0.00 \mathrm{E}+00$ & 0.0 \\
\hline 154-Eu & $0.00 \mathrm{E}+00$ & 0.0 \\
\hline $155-\mathrm{Eu}$ & $0.00 \mathrm{E}+00$ & 0.0 \\
\hline 226-Ra & $0.00 \mathrm{E}+00$ & 0.0 \\
\hline 227-Ac & $0.00 \mathrm{E}+00$ & 0.0 \\
\hline 228-Ra & $0.00 \mathrm{E}+00$ & 0.0 \\
\hline 229-Th & $0.00 \mathrm{E}+00$ & 0.0 \\
\hline 231-Pa & $0.00 \mathrm{E}+00$ & 0.0 \\
\hline 232-Th & $0.00 \mathrm{E}+00$ & 0.0 \\
\hline $232-U$ & $0.00 \mathrm{E}+00$ & 0.0 \\
\hline $233-U$ & $0.00 \mathrm{E}+00$ & 0.0 \\
\hline $234-U$ & $0.00 \mathrm{E}+00$ & 0.0 \\
\hline $235-U$ & $0.00 \mathrm{E}+00$ & 0.0 \\
\hline $236-\mathrm{U}$ & $0.00 \mathrm{E}+00$ & 0.0 \\
\hline 237-Np & $0.00 \mathrm{E}+00$ & 0.0 \\
\hline $238-\mathrm{Pu}$ & $0.00 \mathrm{E}+00$ & 0.0 \\
\hline $238-\mathrm{U}$ & $0.00 \mathrm{E}+00$ & 0.0 \\
\hline 239-Pu & $0.00 \mathrm{E}+00$ & 0.0 \\
\hline $240-\mathrm{Pu}$ & $0.00 \mathrm{E}+00$ & 0.0 \\
\hline 241-Am & $0.00 \mathrm{E}+00$ & 0.0 \\
\hline $241-\mathrm{Pu}$ & $0.00 \mathrm{E}+00$ & 0.0 \\
\hline 242-Cm & $0.00 \mathrm{E}+00$ & 0.0 \\
\hline $242-\mathrm{Pu}$ & $0.00 \mathrm{E}+00$ & 0.0 \\
\hline
\end{tabular}




\begin{tabular}{|c|c|c|}
\hline \multicolumn{3}{|c|}{$\begin{array}{l}\text { Inventory based on dst inventory calculations from both } \\
\text { nomalized TRAC or BBI as of } 10 / 1 / 98 \text { where available. File is }\end{array}$} \\
\hline dst_inv_99.csv & & \\
\hline TANK & AZ-101 & Concentration \\
\hline SOLUBLE & AZ-101 & mg/Liter \\
\hline 243-Am & $0.00 \mathrm{E}+00$ & 0.0 \\
\hline 243-Cm & $0.00 \mathrm{E}+00$ & 0.0 \\
\hline 244-Cm & $0.00 \mathrm{E}+00$ & 0.0 \\
\hline $3-\mathrm{H}$ & $0.00 \mathrm{E}+00$ & 0.0 \\
\hline $59-\mathrm{Ni}$ & $0.00 \mathrm{E}+00$ & 0.0 \\
\hline 60-Co & $0.00 \mathrm{E}+00$ & 0.0 \\
\hline 63-Ni & $0.00 \mathrm{E}+00$ & 0.0 \\
\hline 79-Se & $0.00 \mathrm{E}+00$ & 0.0 \\
\hline $90-\mathrm{Sr}$ & $3.05 \mathrm{E}-02$ & 0.0 \\
\hline $90-Y$ & $0.00 \mathrm{E}+00$ & 0.0 \\
\hline $93 \mathrm{~m}-\mathrm{Nb}$ & $0.00 \mathrm{E}+00$ & 0.0 \\
\hline $93-Z r$ & $0.00 \mathrm{E}+00$ & 0.0 \\
\hline 99-Tc & $4.40 \mathrm{E}+01$ & 14.5 \\
\hline $\mathrm{Ag}+$ & $0.00 \mathrm{E}+00$ & 0.0 \\
\hline $\mathrm{Al}+3$ & $3.23 \mathrm{E}+04$ & 10667.7 \\
\hline $\mathrm{As}+5$ & $0.00 \mathrm{E}+00$ & 0.0 \\
\hline $\mathrm{B}+3$ & $0.00 \mathrm{E}+00$ & 0.0 \\
\hline $\mathrm{Ba}+2$ & $0.00 \mathrm{E}+00$ & 0.0 \\
\hline $\mathrm{Be}+2$ & $0.00 \mathrm{E}+00$ & 0.0 \\
\hline $\mathrm{Bi}+3$ & $0.00 \mathrm{E}+00$ & 0.0 \\
\hline $\mathrm{Ca}+2$ & $0.00 \mathrm{E}+00$ & 0.0 \\
\hline $\mathrm{Cd}+2$ & $0.00 \mathrm{E}+00$ & 0.0 \\
\hline $\mathrm{Ce}+3$ & $0.00 \mathrm{E}+00$ & 0.0 \\
\hline Cl- & $6.04 \mathrm{E}+02$ & 199.5 \\
\hline $\mathrm{CN}-$ & $0.00 \mathrm{E}+00$ & 0.0 \\
\hline $\mathrm{Co}+3$ & $0.00 \mathrm{E}+00$ & 0.0 \\
\hline $\mathrm{CO} 3-2$ & $0.00 \mathrm{E}+00$ & 0.0 \\
\hline Cr(TOTAL) & $2.21 \mathrm{E}+03$ & 729.9 \\
\hline $\mathrm{Cs}+$ & $1.13 \mathrm{E}+02$ & 37.3 \\
\hline $\mathrm{Cu}+2$ & $0.00 \mathrm{E}+00$ & 0.0 \\
\hline F- & $5.49 \mathrm{E}+03$ & 1813.2 \\
\hline $\mathrm{Fe}+3$ & $0.00 \mathrm{E}+00$ & 0.0 \\
\hline $\mathrm{H} 2 \mathrm{O}$ & $2.76 \mathrm{E}+06$ & 911542.7 \\
\hline $\mathrm{Hg}+2$ & $0.00 \mathrm{E}+00$ & 0.0 \\
\hline $\mathrm{K}+$ & $1.40 \mathrm{E}+04$ & 4623.8 \\
\hline $\mathrm{La}+3$ & $0.00 \mathrm{E}+00$ & 0.0 \\
\hline $\mathrm{Li}+$ & $0.00 \mathrm{E}+00$ & 0.0 \\
\hline $\mathrm{Mg}+2$ & $0.00 \mathrm{E}+00$ & 0.0 \\
\hline
\end{tabular}




\begin{tabular}{|c|c|c|}
\hline \multicolumn{3}{|c|}{$\begin{array}{l}\text { Inventory based on dst inventory calculations from both } \\
\text { nomalized TRAC or BBI as of } 10 / 1 / 98 \text { where available. File is }\end{array}$} \\
\hline dst_inv_99.csv & & \\
\hline TANK & AZ-101 & Concentration \\
\hline SOLUBLE & AZ-101 & mg/Liter \\
\hline$M n+4$ & $0.00 \mathrm{E}+00$ & 0.0 \\
\hline $\mathrm{Mo}+6$ & $0.00 \mathrm{E}+00$ & 0.0 \\
\hline $\mathrm{Na}+$ & $3.30 \mathrm{E}+05$ & 108988.8 \\
\hline $\mathrm{Nd}+3$ & $0.00 \mathrm{E}+00$ & 0.0 \\
\hline $\mathrm{NH} 3$ & $9.47 \mathrm{E}+02$ & 312.8 \\
\hline $\mathrm{Ni}+2$ & $0.00 \mathrm{E}+00$ & 0.0 \\
\hline NO2- & $1.97 \mathrm{E}+05$ & 65063.0 \\
\hline NO3- & $2.29 \mathrm{E}+05$ & 75631.6 \\
\hline $\mathrm{OH}-$ & $0.00 \mathrm{E}+00$ & 0.0 \\
\hline $\mathrm{Pb}+2$ & $0.00 \mathrm{E}+00$ & 0.0 \\
\hline $\mathrm{Pd}+2$ & $0.00 \mathrm{E}+00$ & 0.0 \\
\hline PO4-3 & $4.55 \mathrm{E}+03$ & 1502.7 \\
\hline $\mathrm{Pr}+3$ & $0.00 \mathrm{E}+00$ & 0.0 \\
\hline $\mathrm{Pu}+4$ & $0.00 \mathrm{E}+00$ & 0.0 \\
\hline $\mathrm{Rb}+$ & $0.00 \mathrm{E}+00$ & 0.0 \\
\hline $\mathrm{Rh}+3$ & $0.00 \mathrm{E}+00$ & 0.0 \\
\hline $\mathrm{Ru}+3$ & $0.00 \mathrm{E}+00$ & 0.0 \\
\hline $\mathrm{Sb}+5$ & $0.00 \mathrm{E}+00$ & 0.0 \\
\hline $\mathrm{Se}+6$ & $0.00 \mathrm{E}+00$ & 0.0 \\
\hline $\mathrm{Si}+4$ & $0.00 \mathrm{E}+00$ & 0.0 \\
\hline $\mathrm{SO} 4-2$ & $5.35 \mathrm{E}+04$ & 17669.4 \\
\hline $\mathrm{Sr}+2$ & $0.00 \mathrm{E}+00$ & 0.0 \\
\hline $\mathrm{Ta}+5$ & $0.00 \mathrm{E}+00$ & 0.0 \\
\hline $\mathrm{Tc}+7$ & $0.00 \mathrm{E}+00$ & 0.0 \\
\hline $\mathrm{Te}+6$ & $0.00 \mathrm{E}+00$ & 0.0 \\
\hline $\mathrm{Th}+4$ & $0.00 \mathrm{E}+00$ & 0.0 \\
\hline $\mathrm{Ti}+4$ & $0.00 \mathrm{E}+00$ & 0.0 \\
\hline $\mathrm{Tl}+3$ & $0.00 \mathrm{E}+00$ & 0.0 \\
\hline TOC & $3.57 \mathrm{E}+03$ & 1179.1 \\
\hline U(TOTAL) & $0.00 \mathrm{E}+00$ & 0.0 \\
\hline $\mathrm{V}+5$ & $0.00 \mathrm{E}+00$ & 0.0 \\
\hline $\mathrm{W}+6$ & $0.00 \mathrm{E}+00$ & 0.0 \\
\hline $\mathrm{Y}+3$ & $0.00 \mathrm{E}+00$ & 0.0 \\
\hline $\mathrm{Zn}+2$ & $0.00 \mathrm{E}+00$ & 0.0 \\
\hline $\mathrm{Zr}+4$ & $9.30 \mathrm{E}+00$ & 3.1 \\
\hline Total, kg & $3.63 \mathrm{E}+06$ & \\
\hline Density, kg/l & 1.2 & \\
\hline Volume, liters & $3.03 \mathrm{E}+06$ & \\
\hline
\end{tabular}


Inventory based on dst inventory calculations from both nomalized TRAC or BBI as of 10/1/98 where available. File is

\begin{tabular}{|c|c|c|}
\hline dst_inv_99.csv & & \\
\hline & & \\
\hline TANK & AZ-101 & Concentration \\
\hline SOLUBLE & AZ-101 & mg/Liter \\
\hline Volume, gallons & $8.00 \mathrm{E}+05$ & \\
\hline
\end{tabular}




\section{Table 43 Hydroxide and Carbonate Basis for B Envelope Simulant}

The basis for Hydroxide and Carbonate

The value for both of these in the BBI is 0 while

I need some to balance the $\mathrm{Na}+$.

I decide to use the following Source.

G. K.Patello and K. D. Wiemers

TWRS Privatization Phase 1 Waste Characterization Data Evaluation for the Request for Proposal

PNNL-11109

\begin{tabular}{|l|r|r|r|l|l|}
\hline Table 2.3 & mg/Liter & Mole Wt & $\begin{array}{l}\text { Concentrati } \\
\text { on }\end{array}$ & units & Na+ Moles \\
\hline Hydroxide & 11300 & 17.00734 & 0.664419 & $\mathrm{M}$ & 0.664419 \\
\hline TIC & 5780 & 12.011 & 0.481226 & $\mathrm{M}$ & 0.962451 \\
\hline
\end{tabular}

Sodium that needs to be balanced is 1.30 moles.

I will ratio the $\mathrm{OH} /(\mathrm{OH}+\mathrm{CO} 3)$ and $\mathrm{CO} 3 /(\mathrm{OH}+\mathrm{CO} 3)$. Requires

\begin{tabular}{|l|r|r|r|l|r|}
\hline & Moles/Liter & Mole Wt & mg/Liter & & \\
\hline OH for $\mathrm{Na}$ & 0.530924 & 17.00734 & 9030 & & Na+ Moles \\
\hline $\mathrm{CO} 3$ for $\mathrm{Na}$ & 0.384538 & 12.011 & 4619 & & 0.530924 \\
\hline
\end{tabular}


Table 44 Calculated “Analytical” Data for Envelope B Simulant

\begin{tabular}{|c|c|c|c|c|c|c|c|}
\hline Tank AZ101 & 1 Supernate Com & position & & & & & \\
\hline Component & Molecular weight & Concentration & Units & Concentration & Units & Moles of plus & Moles of Minus \\
\hline Aluminum & 26.98154 & 10667.7 & mg/Liter & $3.95 \mathrm{E}-01$ & Molar & & $3.95 \mathrm{E}-01$ \\
\hline Ammonia & 17.03052 & 312.8 & $\mathrm{mg} /$ Liter & $1.84 \mathrm{E}-02$ & Molar & $1.84 \mathrm{E}-02$ & \\
\hline Arsenic & 74.9216 & 0.0 & $\mathrm{mg} /$ Liter & $0.00 \mathrm{E}+00$ & Molar & & $0.00 \mathrm{E}+00$ \\
\hline Barium & 137.33 & 0.0 & $\mathrm{mg} /$ Liter & $0.00 \mathrm{E}+00$ & Molar & $0.00 \mathrm{E}+00$ & \\
\hline Boron & 10.81 & 0.0 & $\mathrm{mg} /$ Liter & $0.00 \mathrm{E}+00$ & Molar & $0.00 \mathrm{E}+00$ & \\
\hline Cadmium & 112.41 & 0.0 & $\mathrm{mg} /$ Liter & $0.00 \mathrm{E}+00$ & Molar & $0.00 \mathrm{E}+00$ & \\
\hline Calcium & 40.08 & 0.0 & $\mathrm{mg} /$ Liter & $0.00 \mathrm{E}+00$ & Molar & $0.00 \mathrm{E}+00$ & \\
\hline Carbonate & 60.0092 & 23075.8 & $\mathrm{mg} /$ Liter & $3.85 \mathrm{E}-01$ & Molar & & 7.69E-01 \\
\hline Cesium & 132.9054 & 37.3 & $\mathrm{mg} /$ Liter & $2.81 \mathrm{E}-04$ & Molar & $2.81 \mathrm{E}-04$ & \\
\hline Chloride & 35.453 & 199.5 & $\mathrm{mg} /$ Liter & $5.63 \mathrm{E}-03$ & Molar & & $5.63 \mathrm{E}-03$ \\
\hline
\end{tabular}




\begin{tabular}{|c|c|c|c|c|c|c|c|}
\hline \multicolumn{8}{|c|}{ Tank AZ101 Supernate Composition } \\
\hline Component & Molecular weight & Concentration & Units & Concentration & Units & Moles of plus & Moles of Minus \\
\hline Chromium & 51.996 & 729.9 & $\mathrm{mg} /$ Liter & $1.40 \mathrm{E}-02$ & Molar & & $2.81 \mathrm{E}-02$ \\
\hline Copper & 63.546 & 0.0 & $\mathrm{mg} /$ Liter & $0.00 \mathrm{E}+00$ & Molar & $0.00 \mathrm{E}+00$ & \\
\hline Fluoride & 18.998 & 1813.2 & $\mathrm{mg} /$ Liter & $9.54 \mathrm{E}-02$ & Molar & & $9.54 \mathrm{E}-02$ \\
\hline Hydroxide & 17.00734 & 9029.6 & $\mathrm{mg} /$ Liter & $5.31 \mathrm{E}-01$ & Molar & & $5.31 \mathrm{E}-01$ \\
\hline Iron & 55.847 & 0.0 & $\mathrm{mg} /$ Liter & $0.00 \mathrm{E}+00$ & Molar & $0.00 \mathrm{E}+00$ & \\
\hline Lanthanum & 138.9055 & 0.0 & $\mathrm{mg} /$ Liter & $0.00 \mathrm{E}+00$ & Molar & $0.00 \mathrm{E}+00$ & \\
\hline Lead & 207.2 & 0.0 & $\mathrm{mg} /$ Liter & $0.00 \mathrm{E}+00$ & Molar & $0.00 \mathrm{E}+00$ & \\
\hline Lithium & 6.941 & 0.0 & $\mathrm{mg} /$ Liter & $0.00 \mathrm{E}+00$ & Molar & $0.00 \mathrm{E}+00$ & \\
\hline Magnesium & 24.305 & 0.0 & $\mathrm{mg} /$ Liter & $0.00 \mathrm{E}+00$ & Molar & $0.00 \mathrm{E}+00$ & \\
\hline Manganese & 54.938 & 0.0 & $\mathrm{mg} /$ Liter & $0.00 \mathrm{E}+00$ & Molar & $0.00 \mathrm{E}+00$ & \\
\hline Molybdenum & 95.94 & 0.0 & $\mathrm{mg} /$ Liter & $0.00 \mathrm{E}+00$ & Molar & & $0.00 \mathrm{E}+00$ \\
\hline Neodymium & 144.24 & 0.0 & $\mathrm{mg} /$ Liter & $0.00 \mathrm{E}+00$ & Molar & $0.00 \mathrm{E}+00$ & \\
\hline
\end{tabular}




\begin{tabular}{|c|c|c|c|c|c|c|c|}
\hline \multicolumn{8}{|c|}{ Tank AZ101 Supernate Composition } \\
\hline Component & Molecular weight & Concentration & Units & Concentration & Units & Moles of plus & Moles of Minus \\
\hline Nickel & 58.69 & 0.0 & $\mathrm{mg} /$ Liter & $0.00 \mathrm{E}+00$ & Molar & $0.00 \mathrm{E}+00$ & \\
\hline Nitrate & 62.0049 & 75631.6 & $\mathrm{mg} /$ Liter & $1.22 \mathrm{E}+00$ & Molar & & $1.22 \mathrm{E}+00$ \\
\hline Nitrite & 46.0055 & 65063.0 & $\mathrm{mg} /$ Liter & $1.41 \mathrm{E}+00$ & Molar & & $1.41 \mathrm{E}+00$ \\
\hline Phosphate & 94.97136 & 1502.7 & $\mathrm{mg} /$ Liter & $1.58 \mathrm{E}-02$ & Molar & & $4.75 \mathrm{E}-02$ \\
\hline Potassium & 39.0983 & 4623.8 & $\mathrm{mg} /$ Liter & $1.18 \mathrm{E}-01$ & Molar & $1.18 \mathrm{E}-01$ & \\
\hline Rhenium & 186.207 & & mg/Liter & $0.00 \mathrm{E}+00$ & Molar & & $0.00 \mathrm{E}+00$ \\
\hline Rhodium & 102.9055 & 0.0 & $\mathrm{mg} /$ Liter & $0.00 \mathrm{E}+00$ & Molar & $0.00 \mathrm{E}+00$ & \\
\hline Ruthenium & 101.07 & 0.0 & $\mathrm{mg} /$ Liter & $0.00 \mathrm{E}+00$ & Molar & $0.00 \mathrm{E}+00$ & \\
\hline Selenium & 78.96 & 0.0 & $\mathrm{mg} /$ Liter & $0.00 \mathrm{E}+00$ & Molar & & $0.00 \mathrm{E}+00$ \\
\hline Silicon & 28.0855 & 0.0 & $\mathrm{mg} /$ Liter & $0.00 \mathrm{E}+00$ & Molar & & $0.00 \mathrm{E}+00$ \\
\hline Silver & 107.8682 & 0.0 & $\mathrm{mg} /$ Liter & $0.00 \mathrm{E}+00$ & Molar & $0.00 \mathrm{E}+00$ & \\
\hline Sodium & 22.9898 & 108988.8 & $\mathrm{mg} /$ Liter & $4.74 \mathrm{E}+00$ & Molar & $4.74 \mathrm{E}+00$ & \\
\hline
\end{tabular}




\begin{tabular}{|c|c|c|c|c|c|c|c|}
\hline \multicolumn{8}{|c|}{ Tank AZ101 Supernate Composition } \\
\hline Component & Molecular weight & Concentration & Units & Concentration & Units & Moles of plus & Moles of Minus \\
\hline Strontium & 87.62 & 0.0 & $\mathrm{mg} /$ Liter & $0.00 \mathrm{E}+00$ & Molar & $0.00 \mathrm{E}+00$ & \\
\hline Sulfate & 96.0576 & 17669.4 & $\mathrm{mg} /$ Liter & $1.84 \mathrm{E}-01$ & Molar & & $3.68 \mathrm{E}-01$ \\
\hline Tellurium & 127.6 & 0.0 & $\mathrm{mg} /$ Liter & $0.00 \mathrm{E}+00$ & Molar & & $0.00 \mathrm{E}+00$ \\
\hline Titanium & 47.88 & 0.0 & $\mathrm{mg} /$ Liter & $0.00 \mathrm{E}+00$ & Molar & & $0.00 \mathrm{E}+00$ \\
\hline TIC & 12.011 & 4618.7 & mg/Liter & $3.85 \mathrm{E}-01$ & Molar & & \\
\hline Vanadium & 50.9415 & 0.0 & $\mathrm{mg} /$ Liter & $0.00 \mathrm{E}+00$ & Molar & & $0.00 \mathrm{E}+00$ \\
\hline Zinc & 65.38 & 0.0 & $\mathrm{mg} / \mathrm{Liter}$ & $0.00 \mathrm{E}+00$ & Molar & $0.00 \mathrm{E}+00$ & \\
\hline Zirconium & 91.22 & 3.1 & mg/Liter & 3.37E-05 & Molar & & $6.73 \mathrm{E}-05$ \\
\hline Totals & & & & & & 4.88 & 4.87 \\
\hline
\end{tabular}




\section{WESTINGHOUSE SAVANNAH RIVER COMPANY}

Hanford Waste Simulants Created to Support Research and

Development on the River Protection Project - Waste Treatment Plant
Report: $\quad$ WSRC-TR-2000-00338

SRT-RPP-2000-00017

Revision (Date): $\quad 0(02 / 22 / 2001)$

Page: $\quad 83$ of 142

Table 45 Compound Calculations for Envelope B Simulant

\begin{tabular}{|c|c|c|c|c|c|c|c|c|c|}
\hline & & & & & & & Formula Weight & Mass Needed & Mass of $\mathrm{H} 2 \mathrm{O}$ \\
\hline Compounds & Moles & Nitrate Moles & Contains [Na] & Moles of Na Needed & Wt \% Carbon & Formula & grams & grams & grams \\
\hline $\begin{array}{l}\text { Aluminum } \\
\text { trihydroxide }\end{array}$ & $3.95 \mathrm{E}-01$ & & & $3.95 \mathrm{E}-01$ & & $\mathrm{Al}(\mathrm{OH}) 3$ & 78 & 30.839 & $0.00 \mathrm{E}+00$ \\
\hline $\begin{array}{l}\text { Ammonium } \\
\text { Nitrate }\end{array}$ & $1.84 \mathrm{E}-02$ & $1.84 \mathrm{E}-02$ & & & & NH4NO3 & 80.04 & 1.470 & \\
\hline Barium Nitrate & $0.00 \mathrm{E}+00$ & $0.00 \mathrm{E}+00$ & & & & $\mathrm{Ba}(\mathrm{NO} 3) 2$ & 261.35 & 0.000 & \\
\hline Boric Acid & $0.00 \mathrm{E}+00$ & & & $0.00 \mathrm{E}+00$ & & $\mathrm{H} 3 \mathrm{BO} 3$ & 61.83 & 0.000 & \\
\hline Cadmium Nitrate & $0.00 \mathrm{E}+00$ & $0.00 \mathrm{E}+00$ & & & & $\mathrm{Cd}(\mathrm{NO} 3) 2.4 \mathrm{H} 2 \mathrm{O}$ & 308.47 & 0.000 & $0.00 \mathrm{E}+00$ \\
\hline Calcium Nitrate & $0.00 \mathrm{E}+00$ & $0.00 \mathrm{E}+00$ & & & & $\mathrm{Ca}(\mathrm{NO} 3) 2.4 \mathrm{H} 2 \mathrm{O}$ & 236.15 & 0.000 & $0.00 \mathrm{E}+00$ \\
\hline Cesium Nitrate & $2.81 \mathrm{E}-04$ & $2.81 \mathrm{E}-04$ & & & & CsNO3 & 194.91 & 0.055 & \\
\hline Sodium Chromate & $1.40 \mathrm{E}-02$ & & $2.81 \mathrm{E}-02$ & & & $\mathrm{Na} 2 \mathrm{CrO} 4$ & 161.97 & 2.274 & \\
\hline Copper Nitrate & $0.00 \mathrm{E}+00$ & $0.00 \mathrm{E}+00$ & & & & $\mathrm{Cu}(\mathrm{NO} 3) 2.2 .5 \mathrm{H} 2 \mathrm{O}$ & 232.59 & 0.000 & $0.00 \mathrm{E}+00$ \\
\hline $\begin{array}{l}\text { Ethylenediaminet } \\
\text { etraacetic acid }\end{array}$ & $0.00 \mathrm{E}+00$ & & $0.00 \mathrm{E}+00$ & $0.00 \mathrm{E}+00$ & 32.3 & Na2EDTA.2H2O & 372.24 & 0.000 & \\
\hline Ferric Nitrate & $0.00 \mathrm{E}+00$ & $0.00 \mathrm{E}+00$ & & & & $\mathrm{Fe}(\mathrm{NO} 3) 3.9 \mathrm{H} 2 \mathrm{O}$ & 404 & 0.000 & $0.00 \mathrm{E}+00$ \\
\hline $\begin{array}{l}\text { Lanthanum } \\
\text { Nitrate }\end{array}$ & $0.00 \mathrm{E}+00$ & $0.00 \mathrm{E}+00$ & & & & $\mathrm{La}(\mathrm{NO} 3) 3.6 \mathrm{H} 2 \mathrm{O}$ & 433.03 & 0.000 & $0.00 \mathrm{E}+00$ \\
\hline Lead nitrate & $0.00 \mathrm{E}+00$ & $0.00 \mathrm{E}+00$ & & & & $\mathrm{~Pb}(\mathrm{NO} 3) 2$ & 331.2 & 0.000 & \\
\hline
\end{tabular}




\section{WESTINGHOUSE SAVANNAH RIVER COMPANY}

Hanford Waste Simulants Created to Support Research and

Development on the River Protection Project - Waste Treatment Plant
Report: $\quad$ WSRC-TR-2000-00338

SRT-RPP-2000-00017

Revision (Date): $\quad 0(02 / 22 / 2001)$

Page: $\quad 84$ of 142

\begin{tabular}{|c|c|c|c|c|c|c|c|c|c|}
\hline & & & & & & & Formula Weight & Mass Needed & Mass of $\mathrm{H} 2 \mathrm{O}$ \\
\hline Compounds & Moles & Nitrate Moles & Contains [Na] & Moles of Na Needed & Wt \% Carbon & Formula & grams & grams & grams \\
\hline Lithium Chloride & $0.00 \mathrm{E}+00$ & & & & & $\mathrm{LiCl}$ & 42.39 & 0.000 & \\
\hline $\begin{array}{l}\text { Magnesium } \\
\text { Nitrate }\end{array}$ & $0.00 \mathrm{E}+00$ & $0.00 \mathrm{E}+00$ & & & & $\mathrm{Mg}(\mathrm{NO} 3) 2.6 \mathrm{H} 2 \mathrm{O}$ & 256.41 & 0.000 & $0.00 \mathrm{E}+00$ \\
\hline $\begin{array}{l}\text { Manganous } \\
\text { Chloride }\end{array}$ & $0.00 \mathrm{E}+00$ & & & & & $\mathrm{MnCl} 2.4 \mathrm{H} 2 \mathrm{O}$ & 197.9 & 0.000 & $0.00 \mathrm{E}+00$ \\
\hline $\begin{array}{l}\text { Potassium } \\
\text { Molybdate }\end{array}$ & $0.00 \mathrm{E}+00$ & & & & & $\mathrm{~K} 2 \mathrm{MoO} 4$ & 238.14 & 0.000 & \\
\hline $\begin{array}{l}\text { Neodymium } \\
\text { Nitrate }\end{array}$ & $0.00 \mathrm{E}+00$ & $0.00 \mathrm{E}+00$ & & & & $\mathrm{Nd}(\mathrm{NO} 3) 3.6 \mathrm{H} 2 \mathrm{O}$ & 438.35 & 0.000 & $0.00 \mathrm{E}+00$ \\
\hline $\begin{array}{l}\mathrm{n} \text { - } \\
\text { Hydroxyethylene } \\
\text { diaminetriacetic } \\
\text { acid }\end{array}$ & $0.00 \mathrm{E}+00$ & & & 0 & 43.2 & HEDTA & 278.26 & 0.000 & \\
\hline Nickel Nitrate & $0.00 \mathrm{E}+00$ & $0.00 \mathrm{E}+00$ & & & & $\mathrm{Ni}(\mathrm{NO} 3) 2.6 \mathrm{H} 2 \mathrm{O}$ & 290.81 & 0.000 & $0.00 \mathrm{E}+00$ \\
\hline Potassium Nitrate & $1.18 \mathrm{E}-01$ & $1.18 \mathrm{E}-01$ & & & & KNO3 & 101.1 & 11.956 & \\
\hline \begin{tabular}{|l} 
Sodium \\
Perrhenate \\
\end{tabular} & $0.00 \mathrm{E}+00$ & & $0.00 \mathrm{E}+00$ & & & $\mathrm{NaReO} 4$ & 273.19 & 0.000 & \\
\hline Rhodium Nitrate & $0.00 \mathrm{E}+00$ & $0.00 \mathrm{E}+00$ & & & & $\mathrm{Rh}(\mathrm{NO} 3) 3.2 \mathrm{H} 2 \mathrm{O}$ & 324.95 & 0.000 & $0.00 \mathrm{E}+00$ \\
\hline $\begin{array}{l}\text { Ruthenium } \\
\text { Chloride } \\
\end{array}$ & $0.00 \mathrm{E}+00$ & & & & & $\mathrm{RuCl} 3$ & 207.43 & 0.000 & \\
\hline Selenium dioxide & $0.00 \mathrm{E}+00$ & & & $0.00 \mathrm{E}+00$ & & $\mathrm{SeO} 2$ & 110.96 & 0.000 & \\
\hline
\end{tabular}




\section{WESTINGHOUSE SAVANNAH RIVER COMPANY}

Hanford Waste Simulants Created to Support Research and

Development on the River Protection Project - Waste Treatment Plant
Report: $\quad$ WSRC-TR-2000-00338

SRT-RPP-2000-00017

Revision (Date): $\quad 0(02 / 22 / 2001)$

Page: $\quad 85$ of 142

\begin{tabular}{|c|c|c|c|c|c|c|c|c|c|}
\hline & & & & & & & Formula Weight & Mass Needed & Mass of $\mathrm{H} 2 \mathrm{O}$ \\
\hline Compounds & Moles & Nitrate Moles & Contains [Na] & Moles of Na Needed & Wt \% Carbon & Formula & grams & grams & grams \\
\hline $\begin{array}{l}\text { Sodium meta- } \\
\text { silicate }\end{array}$ & $0.00 \mathrm{E}+00$ & & $0.00 \mathrm{E}+00$ & & & $\mathrm{Na} 2 \mathrm{SiO} 3.9 \mathrm{H} 2 \mathrm{O}$ & 284.2 & 0.000 & $0.00 \mathrm{E}+00$ \\
\hline Silver Nitrate & $0.00 \mathrm{E}+00$ & $0.00 \mathrm{E}+00$ & & & & $\mathrm{AgNO} 3$ & 169.87 & 0.000 & \\
\hline Strontium Nitrate & $0.00 \mathrm{E}+00$ & $0.00 \mathrm{E}+00$ & & & & $\mathrm{Sr}(\mathrm{NO} 3) 2$ & 211.63 & 0.000 & \\
\hline Tellurium Dioxide & $0.00 \mathrm{E}+00$ & & & $0.00 \mathrm{E}+00$ & & $\mathrm{TeO} 2$ & 159.6 & 0.000 & \\
\hline $\begin{array}{l}\text { Titanium } \\
\text { Tetrachloride }\end{array}$ & $0.00 \mathrm{E}+00$ & & & & & $\mathrm{TiCl} 4$ & 189.71 & 0.000 & \\
\hline $\begin{array}{l}\text { Vanadium } \\
\text { Pentoxide } \\
\end{array}$ & $0.00 \mathrm{E}+00$ & & & $0.00 \mathrm{E}+00$ & & $\mathrm{~V} 2 \mathrm{O} 5$ & 181.88 & 0.000 & \\
\hline Zinc Nitrate & $0.00 \mathrm{E}+00$ & $0.00 \mathrm{E}+00$ & & & & $\mathrm{Zn}(\mathrm{NO} 3) 2.6 \mathrm{H} 2 \mathrm{O}$ & 297.47 & 0.000 & 0 \\
\hline Zirconyl Nitrate & $3.37 \mathrm{E}-05$ & $6.73427 \mathrm{E}-05$ & & & & $\mathrm{ZrO}(\mathrm{NO} 3) 2 . x \mathrm{H} 2 \mathrm{O}$ & 249.23 & 0.008 & 0.000606085 \\
\hline Sodium Acetate & $0.00 \mathrm{E}+00$ & & $0.00 \mathrm{E}+00$ & & 17.7 & $\mathrm{NaCH} 3 \mathrm{COO} .3 \mathrm{H} 2 \mathrm{O}$ & 136.08 & 0.000 & $0.00 \mathrm{E}+00$ \\
\hline Sodium Bromide & $0.00 \mathrm{E}+00$ & & $0.00 \mathrm{E}+00$ & & & $\mathrm{NaBr}$ & 102.89 & 0.000 & \\
\hline Sodium Carbonate & $3.85 \mathrm{E}-01$ & & 7.69E-01 & & & $\mathrm{Na} 2 \mathrm{CO} 3$ & 105.99 & 40.757 & \\
\hline Sodium Chloride & $5.63 \mathrm{E}-03$ & & $5.63 \mathrm{E}-03$ & & & $\mathrm{NaCl}$ & 58.44 & 0.329 & \\
\hline Sodium Fluoride & $9.54 \mathrm{E}-02$ & & $9.54 \mathrm{E}-02$ & & & $\mathrm{NaF}$ & 41.99 & 4.008 & \\
\hline Sodium Formate & $0.00 \mathrm{E}+00$ & & $0.00 \mathrm{E}+00$ & & 17.7 & HCOONa & 68.01 & 0.000 & \\
\hline Glycolic Acid & $0.00 \mathrm{E}+00$ & & & $0.00 \mathrm{E}+00$ & 31.6 & $\mathrm{HOCH} 2 \mathrm{COOH}$, & 76.05 & 0.000 & 0 \\
\hline
\end{tabular}




\section{WESTINGHOUSE SAVANNAH RIVER COMPANY}

Hanford Waste Simulants Created to Support Research and

Development on the River Protection Project - Waste Treatment Plant
Report: $\quad$ WSRC-TR-2000-00338

SRT-RPP-2000-00017

Revision (Date): $\quad 0(02 / 22 / 2001)$

Page: $\quad 86$ of 142

\begin{tabular}{|c|c|c|c|c|c|c|c|c|c|}
\hline & & & & & & & Formula Weight & Mass Needed & Mass of $\mathrm{H} 2 \mathrm{O}$ \\
\hline Compounds & Moles & Nitrate Moles & Contains [Na] & Moles of Na Needed & Wt \% Carbon & Formula & grams & grams & grams \\
\hline & & & & & & wt $\%$ & & & \\
\hline Sodium Nitrite & $1.41 \mathrm{E}+00$ & & $1.41 \mathrm{E}+00$ & & & $\mathrm{NaNO} 2$ & 69 & 97.583 & \\
\hline Sodium Oxalate & $0.00 \mathrm{E}+00$ & & $0.00 \mathrm{E}+00$ & & 17.9 & $\mathrm{Na} 2 \mathrm{C} 2 \mathrm{O} 4$ & 134 & 0.000 & \\
\hline Sodium Phosphate & $1.58 \mathrm{E}-02$ & & $4.75 \mathrm{E}-02$ & & & $\mathrm{Na} 3 \mathrm{PO} 4.12 \mathrm{H} 2 \mathrm{O}$ & 380.12 & 6.015 & $3.42 \mathrm{E}+00$ \\
\hline Sodium Sulfate & $1.84 \mathrm{E}-01$ & & $3.68 \mathrm{E}-01$ & & & $\mathrm{Na} 2 \mathrm{SO} 4$ & 142.04 & 26.128 & \\
\hline Sodium Nitrate & $1.08 \mathrm{E}+00$ & $1.08 \mathrm{E}+00$ & $1.08 \mathrm{E}+00$ & & & NaNO3 & 84.99 & 92.027 & \\
\hline Sodium Hydroxide & $9.26 \mathrm{E}-01$ & & $9.26 \mathrm{E}-01$ & & & $\mathrm{NaOH}$ & 40 & 37.052 & \\
\hline Totals & & $1.22 \mathrm{E}+00$ & $4.74 \mathrm{E}+00$ & & & & & 350.499 & $3.42 \mathrm{E}+00$ \\
\hline Target & & $1.22 \mathrm{E}+00$ & $4.74 \mathrm{E}+00$ & & & & & & \\
\hline & & $0.00 \mathrm{E}+00$ & $3.83 \mathrm{E}-03$ & & & & & & \\
\hline $\begin{array}{l}\text { Additional } \mathrm{NaOH} \\
\text { to match } \mathrm{Na}+\end{array}$ & $3.83 \mathrm{E}-03$ & & & & & $\mathrm{NaOH}$ & 40 & 0.153 & \\
\hline Total $\mathrm{NaOH}$ & $9.30 \mathrm{E}-01$ & & & & & $\mathrm{NaOH}$ & 40 & 37.205 & \\
\hline Measured Density & 1.2 & grams $/ \mathrm{mL}$ & & & & & & & \\
\hline
\end{tabular}




\section{WESTINGHOUSE SAVANNAH RIVER COMPANY}

Hanford Waste Simulants Created to Support Research and Development on the River Protection Project - Waste Treatment Plant
Report: $\quad$ WSRC-TR-2000-00338

SRT-RPP-2000-00017

Revision (Date): $\quad 0(02 / 22 / 2001)$

\begin{tabular}{|c|c|c|c|c|c|c|c|c|c|}
\hline & & & & & & & Formula Weight & Mass Needed & Mass of $\mathrm{H} 2 \mathrm{O}$ \\
\hline Compounds & Moles & Nitrate Moles & Contains [Na] & Moles of Na Needed & Wt \% Carbon & Formula & grams & grams & grams \\
\hline $\begin{array}{|ll|}\text { Total } & \text { Solution } \\
\text { Mass } & \\
\end{array}$ & 1200 & grams $/ \mathrm{mL}$ & & & & & & & \\
\hline$\%$ Solids & $2.92 \mathrm{E}+01$ & & & & & & & & \\
\hline Mass of Water & $8.50 \mathrm{E}+02$ & grams & & & & & & & \\
\hline
\end{tabular}




\section{Table 46 Best Basis Envelope B Recipe}

Best Basis Inventory Envelope B Recipe

\section{Volume of Feed}

$1000 \mathrm{~mL}$

In a tared

1000 mL Volumetric Flask add

\begin{tabular}{|l|l|l|}
\cline { 2 - 3 } \multicolumn{1}{c|}{} & grams & Actual Wt, grams \\
\hline Water & 200 & \\
\hline
\end{tabular}

Transition Metals and Complexing agents

\begin{tabular}{|l|l|r|l|}
\hline Compounds & Formula & Mass Needed & Actual Wt, grams \\
\hline Ammonium Nitrate & $\mathrm{NH} 4 \mathrm{NO} 3$ & 1.470 & \\
\hline Cesium Nitrate & $\mathrm{CsNO3}$ & 0.055 & \\
\hline Potassium Nitrate & $\mathrm{KNO} 3$ & 11.956 & \\
\hline Zirconyl Nitrate & $\mathrm{ZrO}(\mathrm{NO} 3) 2 . \mathrm{xH} 2 \mathrm{O}$ & 0.008 & \\
\hline Sodium Chloride & $\mathrm{NaCl}$ & 0.329 & \\
\hline Sodium Fluoride & $\mathrm{NaF}$ & 4.008 & \\
\hline Sodium Chromate & $\mathrm{Na} 2 \mathrm{CrO} 4$ & 2.274 & \\
\hline Sodium Sulfate & $\mathrm{Na} 2 \mathrm{SO} 4$ & 26.128 & \\
\hline
\end{tabular}


In a separate container mix the following

\begin{tabular}{|l|l|r|l|}
\hline & Formula & Mass Needed & Actual Wt, grams \\
\hline Cluminum trihydroxide & $\mathrm{Al}(\mathrm{OH}) 3$ & 30.839 & \\
\hline Sodium Hydroxide & $\mathrm{NaOH}$ & 37.205 & \\
\hline Sodium Phosphate & $\mathrm{Na3PO} 4.12 \mathrm{H} 2 \mathrm{O}$ & 6.015 & \\
\hline
\end{tabular}

\begin{tabular}{|l|l|l|}
\hline Add & grams & Actual Wt, grams \\
\hline Water & 300 & \\
\hline
\end{tabular}

Mix thoroughly. Then add this solution to the volumetric flask.

\begin{tabular}{|l|l|l|l|}
\hline Add & Formula & Mass Needed & Actual Wt, grams \\
\hline Sodium Carbonate & $\mathrm{Na2CO3}$ & & \\
\hline
\end{tabular}

Mix thoroughly.

\begin{tabular}{|l|l|l|l|}
\hline Add & Formula & Mass Needed & Actual Wt, grams \\
\hline Sodium Nitrate & NaNO3 & 92.027 & \\
\hline Sodium Nitrite & NaNO2 & 97.583 & \\
\hline
\end{tabular}


Mix thoroughly.

Mix thoroughly and dilute to the mark.

\begin{tabular}{|l|l|l|}
\hline Record Final Weight & & grams \\
\hline
\end{tabular}

The final addition of water would be

a density of $1.20 \mathrm{~g} / \mathrm{mL}$. 


\section{Appendix C Envelope C Simulant Spreadsheets}

\section{Table 47 Tank 241-AN-107 Supernate Composition}

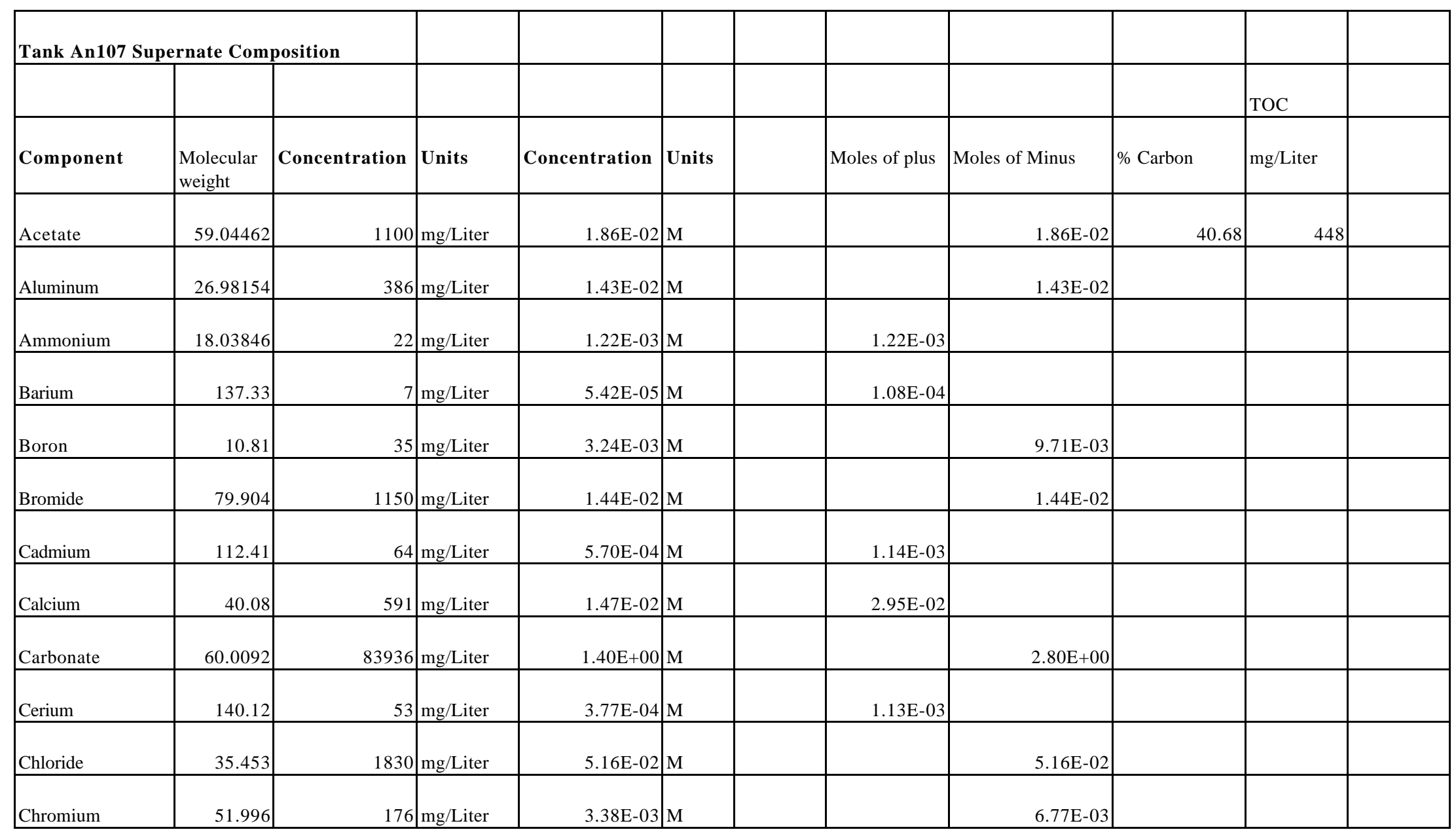




\section{WESTINGHOUSE SAVANNAH RIVER COMPANY}

Hanford Waste Simulants Created to Support Research and

Development on the River Protection Project - Waste Treatment Plant
Report: $\quad$ WSRC-TR-2000-00338

SRT-RPP-2000-00017

Revision (Date): $\quad 0(02 / 22 / 2001)$

Page: $\quad 92$ of 142

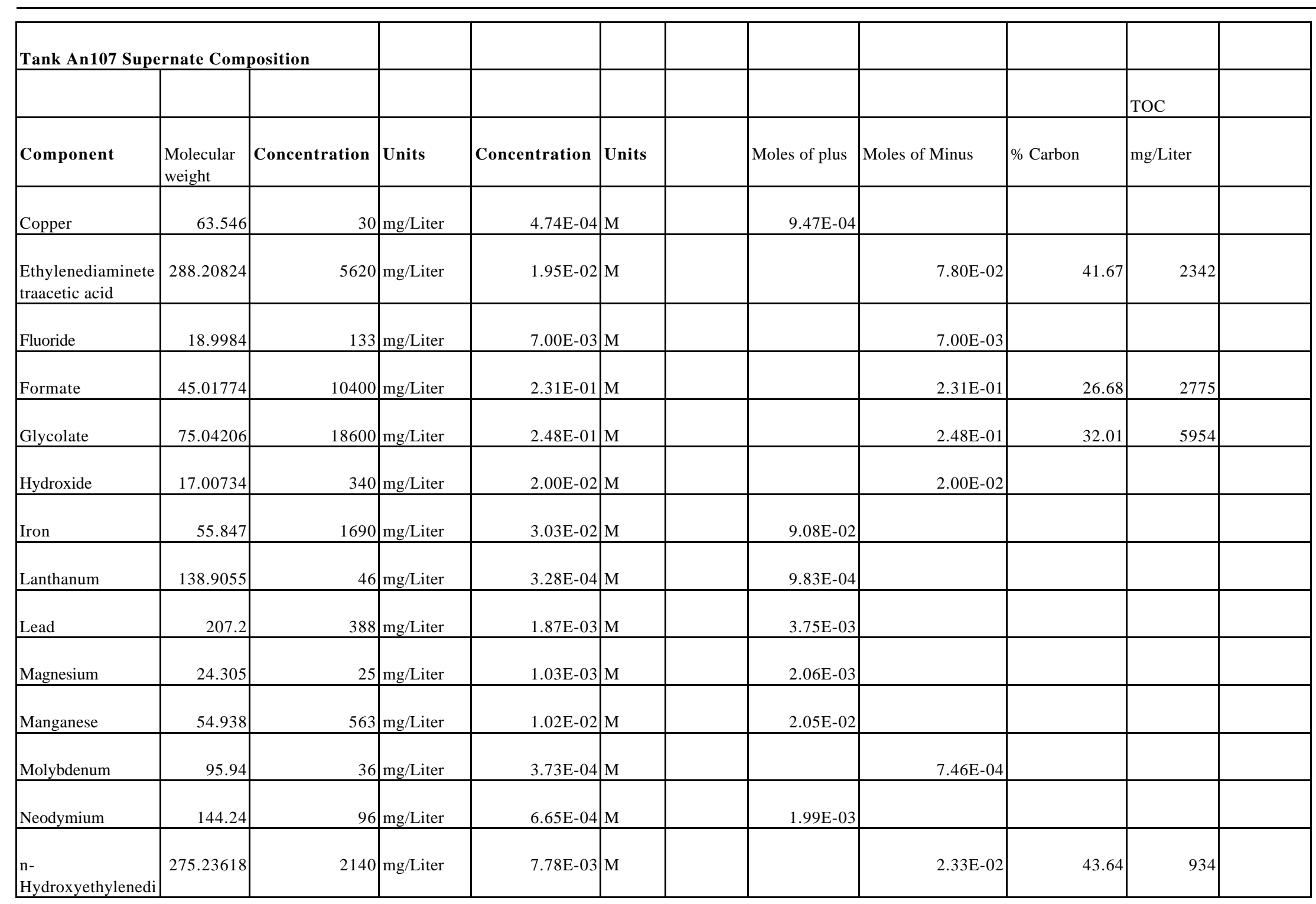




\section{WESTINGHOUSE SAVANNAH RIVER COMPANY}

Hanford Waste Simulants Created to Support Research and

Development on the River Protection Project - Waste Treatment Plant
Report: $\quad$ WSRC-TR-2000-00338

SRT-RPP-2000-00017

Revision (Date): $\quad 0(02 / 22 / 2001)$

Page: $\quad 93$ of 142

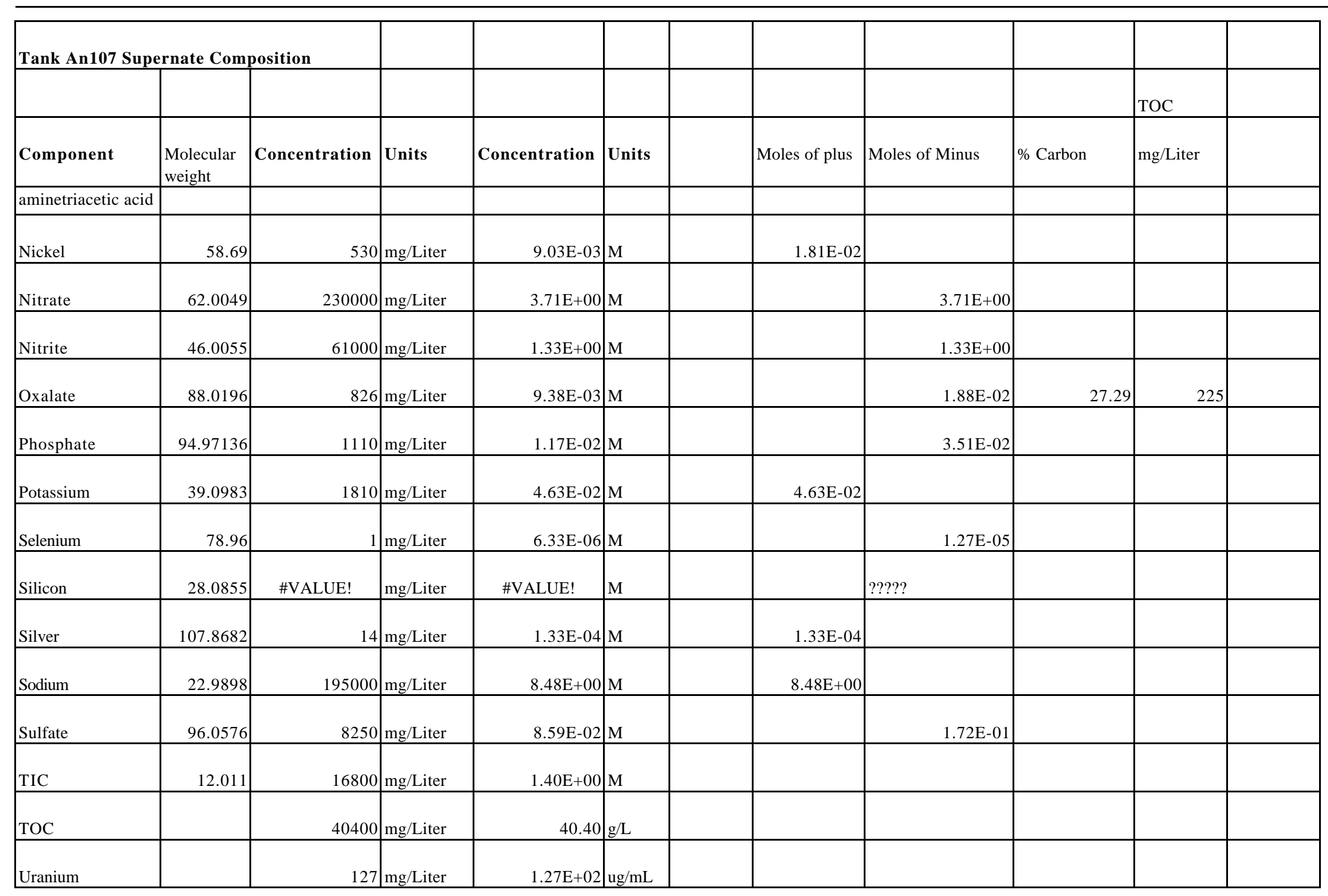




\section{WESTINGHOUSE SAVANNAH RIVER COMPANY}

Hanford Waste Simulants Created to Support Research and Development on the River Protection Project - Waste Treatment Plant
Report: $\quad$ WSRC-TR-2000-00338

SRT-RPP-2000-00017

Revision (Date): $\quad 0(02 / 22 / 2001)$

Page: $\quad 94$ of 142

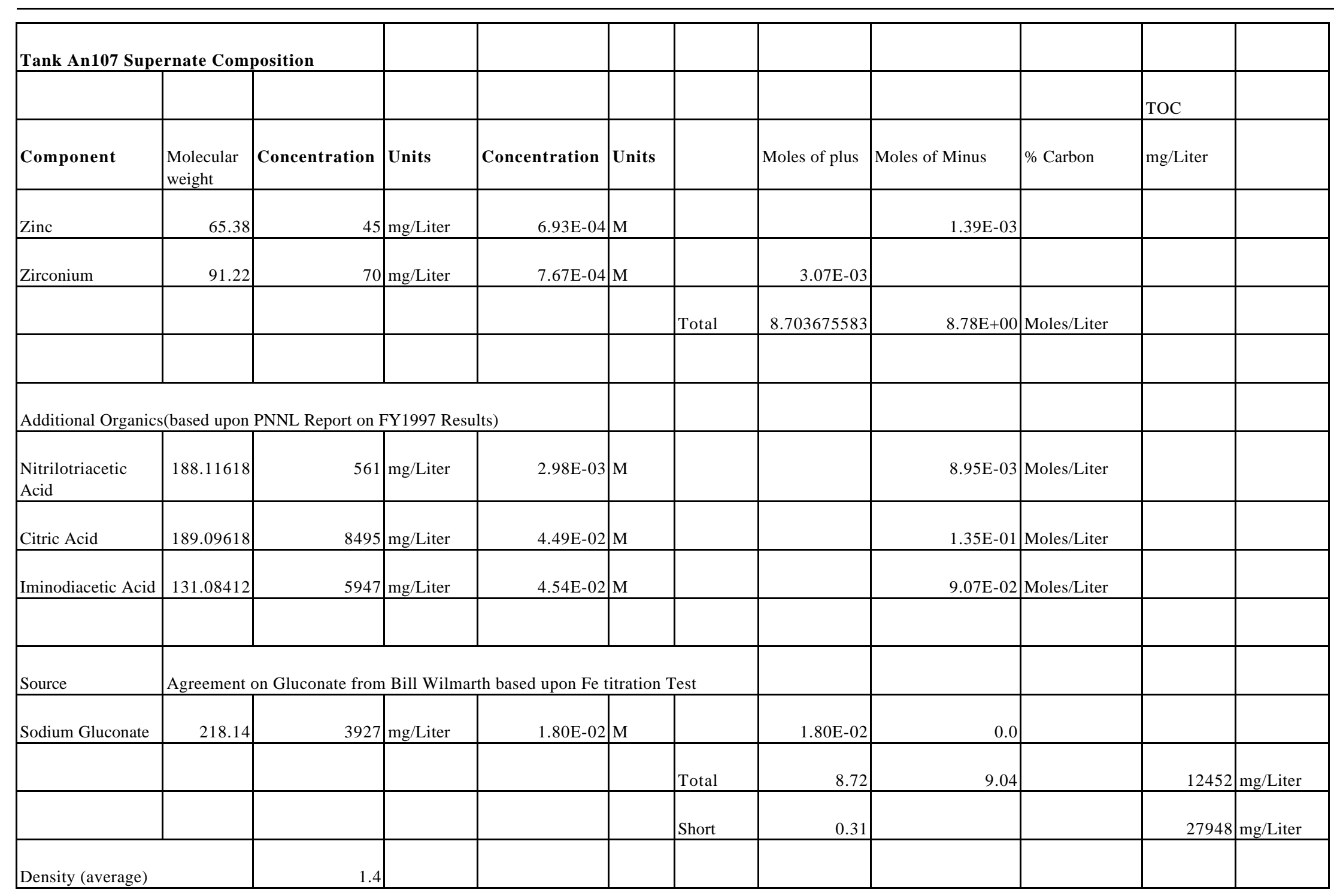




\section{WESTINGHOUSE SAVANNAH RIVER COMPANY}

Hanford Waste Simulants Created to Support Research and

Development on the River Protection Project - Waste Treatment Plant
Report: $\quad$ WSRC-TR-2000-00338

SRT-RPP-2000-00017

Revision (Date): $\quad 0(02 / 22 / 2001)$

Page: $\quad 96$ of 142

Table 48 Compound Calculations for AN-107 Simulant

\begin{tabular}{|c|c|c|c|c|c|c|c|c|c|}
\hline Organic from 96 TOC & 40.4 & & & & & & & & \\
\hline & & & & & & \begin{tabular}{|l} 
Formula \\
Weight
\end{tabular} & Mass Needed & Mass of $\mathrm{H} 2 \mathrm{O}$ & TOC \\
\hline Compounds & Moles & Nitrate Moles & Moles of $\mathrm{Na}$ & Wt \% Carbon & Formula & grams & grams & grams & Grams \\
\hline Aluminum Nitrate & $1.43 \mathrm{E}-02$ & 4.29E-02 & $5.72 \mathrm{E}-02$ & & $\mathrm{Al}(\mathrm{NO} 3) 3.9 \mathrm{H} 2 \mathrm{O}$ & 375.13 & 5.37 & 2.32 & \\
\hline Ammonium Acetate & $1.22 \mathrm{E}-03$ & & & & $\mathrm{NH} 4 \mathrm{Ch} 3 \mathrm{COO}$ & 77.08 & 0.09 & & \\
\hline Barium Nitrate & $5.42 \mathrm{E}-05$ & $1.08 \mathrm{E}-04$ & & & $\mathrm{Ba}(\mathrm{NO} 3) 2$ & 261.35 & 0.01 & & \\
\hline Boric acid & $3.24 \mathrm{E}-03$ & & $9.71 \mathrm{E}-03$ & & $\mathrm{H} 3 \mathrm{BO} 3$ & 61.83 & 0.20 & & \\
\hline Cadmium Nitrate & $5.70 \mathrm{E}-04$ & $1.14 \mathrm{E}-03$ & & & $\mathrm{Cd}(\mathrm{NO} 3) 2.4 \mathrm{H} 2 \mathrm{O}$ & 308.47 & 0.18 & 0.04 & \\
\hline Calcium Nitrate & $1.47 \mathrm{E}-02$ & $2.95 \mathrm{E}-02$ & & & $\mathrm{Ca}(\mathrm{NO} 3) 2.4 \mathrm{H} 2 \mathrm{O}$ & 236.15 & 3.48 & 1.06 & \\
\hline Cerium Nitrate & $3.77 \mathrm{E}-04$ & $1.13 \mathrm{E}-03$ & & & $\mathrm{Ce}(\mathrm{NO} 3) 3.6 \mathrm{H} 2 \mathrm{O}$ & 434.23 & 0.16 & 0.04 & \\
\hline Cesium Nitrate & $1.40 \mathrm{E}-04$ & $1.40 \mathrm{E}-04$ & & & CsNO3 & 194.91 & 0.027 & & \\
\hline Copper Nitrate & 4.74E-04 & $9.47 \mathrm{E}-04$ & & & $\mathrm{Cu}(\mathrm{NO} 3) 2.2 .5 \mathrm{H} 2 \mathrm{O}$ & 232.59 & 0.11 & 0.00 & \\
\hline EDTA & $1.95 \mathrm{E}-02$ & & $3.90 \mathrm{E}-02$ & 32.3 & Na2EDTA & 372.24 & 7.26 & & 2.34 \\
\hline Ferric Nitrate & $3.03 \mathrm{E}-02$ & $9.08 \mathrm{E}-02$ & & & $\mathrm{Fe}(\mathrm{NO} 3) 3.9 \mathrm{H} 2 \mathrm{O}$ & 404 & 12.23 & 4.90 & \\
\hline HEDTA & $7.78 \mathrm{E}-03$ & & $2.33 \mathrm{E}-02$ & 43.2 & HEDTA & 278.26 & 2.16 & & 0.93 \\
\hline Lanthanum Nitrate & $3.28 \mathrm{E}-04$ & $9.83 \mathrm{E}-04$ & & & $\mathrm{La}(\mathrm{NO} 3) 3.6 \mathrm{H} 2 \mathrm{O}$ & 433.03 & 0.14 & 0.04 & \\
\hline
\end{tabular}




\section{WESTINGHOUSE SAVANNAH RIVER COMPANY}

Hanford Waste Simulants Created to Support Research and

Development on the River Protection Project - Waste Treatment Plant
Report: $\quad$ WSRC-TR-2000-00338

SRT-RPP-2000-00017

Revision (Date): $\quad 0(02 / 22 / 2001)$

Page: $\quad 97$ of 142

\begin{tabular}{|c|c|c|c|c|c|c|c|c|c|}
\hline Organic from 96 TOC & 40.4 & & & & & & & & \\
\hline & & & & & & $\begin{array}{l}\text { Formula } \\
\text { Weight }\end{array}$ & Mass Needed & Mass of $\mathrm{H} 2 \mathrm{O}$ & TOC \\
\hline Compounds & Moles & Nitrate Moles & Moles of $\mathrm{Na}$ & Wt \% Carbon & Formula & grams & grams & grams & Grams \\
\hline Lead nitrate & $1.87 \mathrm{E}-03$ & $3.75 \mathrm{E}-03$ & & & $\mathrm{~Pb}(\mathrm{NO} 3) 2$ & 331.2 & 0.62 & & \\
\hline Magnesium Nitrate & $1.03 \mathrm{E}-03$ & $2.06 \mathrm{E}-03$ & & & $\mathrm{Mg}(\mathrm{NO} 3) 2.6 \mathrm{H} 2 \mathrm{O}$ & 256.41 & 0.26 & 0.11 & \\
\hline Manganous Chloride & $1.02 \mathrm{E}-02$ & & & & $\mathrm{MnCl} 2.4 \mathrm{H} 2 \mathrm{O}$ & 197.9 & 2.03 & 0.74 & \\
\hline Neodymium Nitrate & $6.65 \mathrm{E}-04$ & $1.99 \mathrm{E}-03$ & & & $\mathrm{Nd}(\mathrm{NO} 3) 3.6 \mathrm{H} 2 \mathrm{O}$ & 438.35 & 0.29 & 0.07 & \\
\hline Nickel Nitrate & $9.03 \mathrm{E}-03$ & $1.81 \mathrm{E}-02$ & & & $\mathrm{Ni}(\mathrm{NO} 3) 2.6 \mathrm{H} 2 \mathrm{O}$ & 290.81 & 2.63 & 0.98 & \\
\hline Potassium Nitrate & $4.55 \mathrm{E}-02$ & $4.55 \mathrm{E}-02$ & & & KNO3 & 101.1 & 4.60 & & \\
\hline Silver Nitrate & $1.33 \mathrm{E}-04$ & $1.33 \mathrm{E}-04$ & & & $\mathrm{AgNO} 3$ & 169.87 & 0.023 & & \\
\hline Strontium Nitrate & $7.54 \mathrm{E}-05$ & $1.51 \mathrm{E}-04$ & & & $\mathrm{Sr}(\mathrm{NO} 3) 2$ & 211.63 & 0.016 & & \\
\hline Zinc Nitrate & $6.93 \mathrm{E}-04$ & $1.39 \mathrm{E}-03$ & & & $\mathrm{Zn}(\mathrm{NO} 3) 2.6 \mathrm{H} 2 \mathrm{O}$ & 297.47 & 0.21 & 0.07 & \\
\hline Zirconyl Nitrate & $7.67 \mathrm{E}-04$ & $1.53 \mathrm{E}-03$ & & & & 249.23 & 0.19 & 0.01 & \\
\hline Glycolic Acid & $2.48 \mathrm{E}-01$ & & $2.48 \mathrm{E}-01$ & 31.6 & $\mathrm{HOCH} 2 \mathrm{COOH}, 70 \mathrm{wt} \%$ & 76.05 & 26.93 & & 5.95 \\
\hline Sodium Gluconate & $1.80 \mathrm{E}-02$ & & $0.00 \mathrm{E}+00$ & 33.0 & & 218.14 & 3.93 & & 1.30 \\
\hline Citric Acid & $4.49 \mathrm{E}-02$ & & $1.35 \mathrm{E}-01$ & 34.3 & & 210.14 & 9.44 & 0.81 & 3.24 \\
\hline Nitrilotriacetic Acid & $2.98 \mathrm{E}-03$ & & $8.95 \mathrm{E}-03$ & 37.7 & & 191.14 & 0.57 & & 0.21 \\
\hline Iminodiacetic Acid & $4.54 \mathrm{E}-02$ & & $9.07 \mathrm{E}-02$ & 36.1 & & 133.1 & 6.04 & & 2.18 \\
\hline
\end{tabular}




\section{WESTINGHOUSE SAVANNAH RIVER COMPANY}

Hanford Waste Simulants Created to Support Research and Development on the River Protection Project - Waste Treatment Plant
Report: $\quad$ WSRC-TR-2000-00338

SRT-RPP-2000-00017

Revision (Date): $\quad 0(02 / 22 / 2001)$

Page: $\quad 98$ of 142

\begin{tabular}{|c|c|c|c|c|c|c|c|c|c|}
\hline Organic from $96 \mathrm{TOC}$ & 40.4 & & & & & & & & \\
\hline & & & & & & $\begin{array}{l}\text { Formula } \\
\text { Weight }\end{array}$ & Mass Needed & Mass of $\mathrm{H} 2 \mathrm{O}$ & TOC \\
\hline Compounds & Moles & Nitrate Moles & Moles of $\mathrm{Na}$ & Wt \% Carbon & Formula & grams & grams & grams & Grams \\
\hline Total & & $2.42 \mathrm{E}-01$ & $6.12 \mathrm{E}-01$ & & & & & & 16.16 \\
\hline & & Sodium Moles & & & & & & & \\
\hline Sodium Chloride & $3.11 \mathrm{E}-02$ & $3.11 \mathrm{E}-02$ & & & $\mathrm{NaCl}$ & 58.44 & 1.82 & & \\
\hline Sodium Fluoride & $7.00 \mathrm{E}-03$ & $7.00 \mathrm{E}-03$ & & & $\mathrm{NaF}$ & 41.99 & 0.29 & & \\
\hline Sodium Chromate & $3.38 \mathrm{E}-03$ & $6.77 \mathrm{E}-03$ & & & $\mathrm{Na} 2 \mathrm{CrO} 4$ & 161.97 & 0.55 & & \\
\hline Sodium Carbonate & $1.40 \mathrm{E}+00$ & $2.80 \mathrm{E}+00$ & & & $\mathrm{Na} 2 \mathrm{CO} 3$ & 105.99 & 148.25 & & \\
\hline Sodium Hydroxide & $2.00 \mathrm{E}-02$ & $2.00 \mathrm{E}-02$ & & & $\mathrm{NaOH}$ & 40 & 0.80 & & \\
\hline Sodium Nitrite & $1.33 \mathrm{E}+00$ & $1.33 \mathrm{E}+00$ & & & $\mathrm{NaNO} 2$ & 69 & 91.49 & & \\
\hline Sodium Phosphate & $1.17 \mathrm{E}-02$ & $3.51 \mathrm{E}-02$ & & & $\mathrm{Na} 3 \mathrm{PO} 4.12 \mathrm{H} 2 \mathrm{O}$ & 380.12 & 4.44 & 2.52 & \\
\hline Potassium Molybdate & $3.73 \mathrm{E}-04$ & & & & $\mathrm{~K} 2 \mathrm{MoO} 4$ & 238.14 & 0.09 & & \\
\hline Sodium Sulfate & $8.59 \mathrm{E}-02$ & $1.72 \mathrm{E}-01$ & & & $\mathrm{Na} 2 \mathrm{SO} 4$ & 142.04 & 12.20 & & \\
\hline Sodium formate & $2.31 \mathrm{E}-01$ & $2.31 \mathrm{E}-01$ & & 17.7 & $\mathrm{NaHCOO}$ & 68.01 & 15.71 & & 2.77 \\
\hline Sodium Acetate & $1.74 \mathrm{E}-02$ & $1.74 \mathrm{E}-02$ & & 17.7 & $\mathrm{NaCH} 3 \mathrm{COO} .3 \mathrm{H} 2 \mathrm{O}$ & 136.08 & 2.37 & 0.94 & 0.42 \\
\hline Sodium Oxalate & $9.38 \mathrm{E}-03$ & $1.88 \mathrm{E}-02$ & & 17.9 & $\mathrm{Na} 2 \mathrm{C} 2 \mathrm{O} 4$ & 134 & 1.26 & & 0.23 \\
\hline
\end{tabular}




\section{WESTINGHOUSE SAVANNAH RIVER COMPANY}

Hanford Waste Simulants Created to Support Research and Development on the River Protection Project - Waste Treatment Plant
Report: $\quad$ WSRC-TR-2000-00338 SRT-RPP-2000-00017

\section{Revision (Date): $\quad 0(02 / 22 / 2001)$}

\begin{tabular}{|c|c|c|c|c|c|c|c|c|c|c|}
\hline Organic from 96 TOC & 40.4 & & & & & & & & & \\
\hline & & & & & & & $\begin{array}{l}\text { Formula } \\
\text { Weight }\end{array}$ & Mass Needed & Mass of $\mathrm{H} 2 \mathrm{O}$ & TOC \\
\hline Compounds & Moles & Nitrate Moles & & Moles of $\mathrm{Na}$ & Wt \% Carbon & Formula & grams & grams & grams & Grams \\
\hline Total & & $4.66 \mathrm{E}+00$ & & & & & & Total & 13.68 & 19.58 \\
\hline Sodium Nitrate & $3.47 \mathrm{E}+00$ & $3.47 \mathrm{E}+00$ & & & & $\mathrm{NaNO} 3$ & 84.99 & 294.67 & & \\
\hline Sodium Hydroxide & $6.12 \mathrm{E}-01$ & $6.12 \mathrm{E}-01$ & & & & $\mathrm{NaOH}$ & 40 & 24.46 & & \\
\hline Total & & $8.77 \mathrm{E}+00$ & & & & & & & & \\
\hline & & & & & & Gram of Solids & & 688.85 & & \\
\hline & & Grams & & & & & & & & \\
\hline Total Slurry Mass/Liter & & 1429 & & & & & & & & \\
\hline Mass of Water to add & & 740.24 & & & & & & & & \\
\hline Water & & 52.76 & $\%$ & & & & & & & \\
\hline TOC \% Of Actual & & 48.46 & & & & & & & & \\
\hline
\end{tabular}




\section{WESTINGHOUSE SAVANNAH RIVER COMPANY}

Hanford Waste Simulants Created to Support Research and Development on the River Protection Project - Waste Treatment Plant
Report: $\quad$ WSRC-TR-2000-00338

SRT-RPP-2000-00017

Revision (Date): $\quad 0(02 / 22 / 2001)$

Page: $\quad 100$ of 142 


\section{Table 49 AN-107 Supernate Simulant Recipe}

Final C Simulant Recipe

Volume of Feed

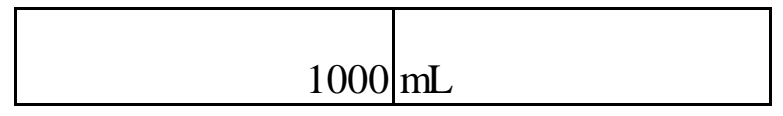

In a tared $\quad 1000 \quad \mathrm{~mL}$ Volumetric Flask add

\begin{tabular}{|l|l|l|}
\cline { 2 - 3 } \multicolumn{1}{c|}{} & grams & Actual Wt, grams \\
\hline Water & 200 & \\
\hline
\end{tabular}

Transition Metals and Complexing agents

\begin{tabular}{|l|l|l|l|}
\hline Compounds & Formula & Mass Needed & Actual Wt, grams \\
\hline Calcium Nitrate & $\mathrm{Ca}(\mathrm{NO} 3) 2.4 \mathrm{H} 2 \mathrm{O}$ & 3.48 & \\
\hline Cerium Nitrate & $\mathrm{Ce}(\mathrm{NO} 3) 3.6 \mathrm{H} 2 \mathrm{O}$ & 0.16 & \\
\hline Cesium Nitrate & $\mathrm{CsNO} 3$ & 0.027 & \\
\hline Copper Nitrate & $\mathrm{Cu}(\mathrm{NO} 3) 2.2 .5 \mathrm{H} 2$ & 0.11 & \\
\hline Ferric Nitrate & $\mathrm{O}$ & 12.23 & \\
\hline Lanthanum Nitrate & $\mathrm{La}(\mathrm{NO} 3) 3.6 \mathrm{H} 2 \mathrm{O}$ & 0.14 & \\
\hline Lead nitrate & $\mathrm{Pb}(\mathrm{NO} 3) 2$ & 0.62 & \\
\hline Magnesium Nitrate & $\mathrm{Mg}(\mathrm{NO} 3) 2.6 \mathrm{H} 2 \mathrm{O}$ & 0.26 & \\
\hline
\end{tabular}




\begin{tabular}{|c|c|c|}
\hline Manganous Chloride & $\mathrm{MnCl} 2.4 \mathrm{H} 2 \mathrm{O}$ & 2.03 \\
\hline Neodymium Nitrate & $\mathrm{Nd}(\mathrm{NO} 3) 3.6 \mathrm{H} 2 \mathrm{O}$ & 0.29 \\
\hline Nickel Nitrate & $\mathrm{Ni}(\mathrm{NO} 3) 2.6 \mathrm{H} 2 \mathrm{O}$ & 2.63 \\
\hline Potassium Nitrate & KNO3 & 4.60 \\
\hline Strontium Nitrate & $\operatorname{Sr}(\mathrm{NO} 3) 2$ & 0.016 \\
\hline Zinc Nitrate & $\mathrm{Zn}(\mathrm{NO} 3) 2.6 \mathrm{H} 2 \mathrm{O}$ & 0.21 \\
\hline Zirconyl Nitrate & & 0.19 \\
\hline EDTA & Na2EDTA & 7.26 \\
\hline HEDTA & HEDTA & 2.16 \\
\hline Sodium Gluconate & & 3.93 \\
\hline Glycolic Acid & & 26.93 \\
\hline Citric Acid & & 9.44 \\
\hline Nitrilotriacetic Acid & & 0.57 \\
\hline Iminodiacetic Acid & & 6.04 \\
\hline Boric acid & $\mathrm{H} 3 \mathrm{BO} 3$ & 0.20 \\
\hline Sodium Chloride & $\mathrm{NaCl}$ & 1.82 \\
\hline Sodium Fluoride & $\mathrm{NaF}$ & 0.29 \\
\hline Sodium Chromate & $\mathrm{Na} 2 \mathrm{CrO} 4$ & 0.55 \\
\hline Sodium Sulfate & $\mathrm{Na} 2 \mathrm{SO} 4$ & 12.20 \\
\hline Potassium Molybdate & K2MoO4 & 0.09 \\
\hline
\end{tabular}

In separate container mix the following 


\begin{tabular}{|l|l|l|l|}
\hline & Formula & Mass Needed & Actual Wt, grams \\
\hline Add & $\mathrm{NaOH}$ & 25.26 & \\
\hline Aluminum Nitrate & $\mathrm{Al}(\mathrm{NO} 3) 3.9 \mathrm{H} 2 \mathrm{O}$ & 5.37 & \\
\hline Sodium Phosphate & $\mathrm{Na3PO} 4.12 \mathrm{H} 2 \mathrm{O}$ & 4.44 & \\
\hline Sodium formate & $\mathrm{NaHCOO}$ & 15.71 & \\
\hline Sodium Acetate & $\mathrm{NaCH} 3 \mathrm{COO} .3 \mathrm{H}$ & 2.37 & \\
\hline Sodium Oxalate & $\mathrm{Na} 2 \mathrm{C} 2 \mathrm{O} 4$ & 1.26 & \\
\hline
\end{tabular}

\begin{tabular}{|l|l|l|}
\hline Add & grams & Actual Wt, grams \\
\hline Water & 200 & \\
\hline
\end{tabular}

Mix thoroughly. Then add this solution to the volumetric flask.

\begin{tabular}{|l|l|l|l|}
\hline & Formula & Mass Needed & Actual Wt, grams \\
\hline Sodium Carbonate & $\mathrm{Na} 2 \mathrm{CO} 3$ & 148.25 & \\
\hline
\end{tabular}

Mix thoroughly.

\begin{tabular}{|l|l|l|l|}
\hline Mix & Formula & Mass Needed & Actual Wt, grams \\
\hline Sodium Nitrate & NaNO3 & 297.29 & \\
\hline
\end{tabular}




\begin{tabular}{|l|r|r|r|}
\hline Sodium Nitrite & NaNO2 & 91.49 & \\
\hline Water & & 100 & \\
\hline
\end{tabular}

Add and Mix thoroughly.

Mix thoroughly and dilute to the mark.

Record Final Weight

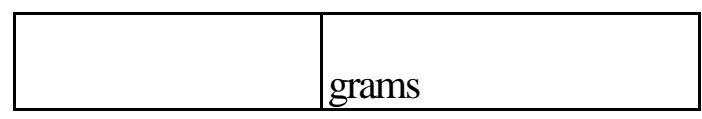

The final addition of water would be

a density of 1.429

$\mathrm{g} / \mathrm{mL}$. 


\section{WESTINGHOUSE SAVANNAH RIVER COMPANY}

Hanford Waste Simulants Created to Support Research and

Development on the River Protection Project - Waste Treatment Plant
Report: $\quad$ WSRC-TR-2000-00338

SRT-RPP-2000-00017

Revision (Date): $\quad 0(02 / 22 / 2001)$

Page: $\quad 105$ of 142

\section{Appendix D Envelope D Simulant Spreadsheets}

\section{Table 50 Solids Composition for Tank AZ-101 Core \#1}

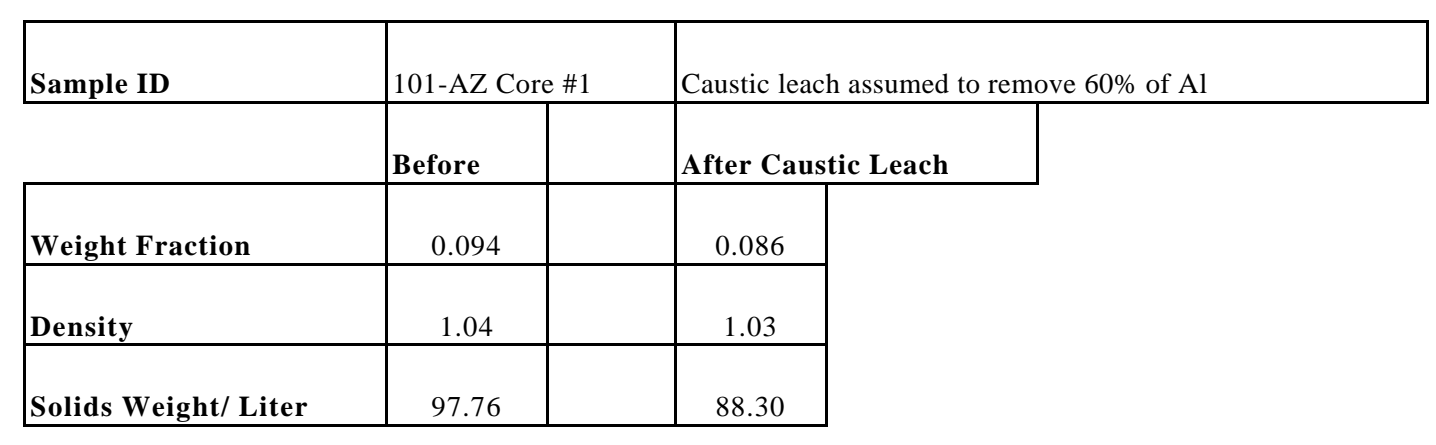

\begin{tabular}{|c|c|c|c|c|c|c|c|c|c|c|c|c|}
\hline & & & & & & & & & & After Caus & tic Leach & \\
\hline Element or Anion & Mole Wt & wt \% & $g / L$ & Moles/L & Wt \% of Solids & Oxide & Mole Wt & \begin{tabular}{|l|}
$\begin{array}{l}\text { Oxide } \\
\text { \%of } \\
\text { Solids }\end{array}$ \\
\end{tabular} & $<?$ & $\begin{array}{lll}\text { Wt } \% & \text { of } \\
\text { Solids }\end{array}$ & \begin{tabular}{|l|}
$\begin{array}{l}\text { Oxide } \\
\text { \%of }\end{array}$ \\
Solids
\end{tabular} & $\begin{array}{l}\text { microg/g } \\
\text { solids }\end{array}$ \\
\hline $\mathrm{Ag}$ & 107.868 & 0.0475 & 0.494 & 0.005 & 0.505 & $\mathrm{AgO}$ & 123.868 & 0.580 & & 0.559 & 0.642 & 5594 \\
\hline $\mathrm{Al}$ & 26.9815 & 0.8020 & 8.3408 & 0.309 & 8.532 & $\mathrm{~A} 12 \mathrm{O} 3$ & 101.961 & 16.121 & & 3.778 & 7.139 & 37782 \\
\hline As & 74.9216 & 0.0380 & 0.3952 & 0.005 & 0.404 & As2O3 & 197.841 & 0.534 & $<$ & 0.448 & 0.591 & 4475 \\
\hline B & 10.81 & 0.0020 & 0.0208 & 0.002 & 0.021 & $\mathrm{~B} 2 \mathrm{O} 3$ & 69.6182 & 0.069 & & 0.024 & 0.076 & 236 \\
\hline $\mathrm{Ba}$ & 137.33 & 0.0153 & 0.15912 & 0.001 & 0.163 & $\mathrm{BaO}$ & 153.329 & 0.182 & & 0.180 & 0.201 & 1802 \\
\hline $\mathrm{Be}$ & 9.01218 & & 0 & 0.000 & 0.000 & $\mathrm{BeO}$ & 25.0116 & 0.000 & $\begin{array}{l}<\mathrm{D} \\
\mathrm{L} \\
\end{array}$ & 0.000 & 0.000 & 0 \\
\hline $\mathrm{Ca}$ & 40.08 & 0.0620 & 0.6448 & 0.016 & 0.660 & $\mathrm{CaO}$ & 56.0794 & 0.923 & & 0.730 & 1.022 & 7302 \\
\hline
\end{tabular}




\section{WESTINGHOUSE SAVANNAH RIVER COMPANY}

Hanford Waste Simulants Created to Support Research and

Development on the River Protection Project - Waste Treatment Plant
Report: $\quad$ WSRC-TR-2000-00338

SRT-RPP-2000-00017

Revision (Date): $\quad 0(02 / 22 / 2001)$

\begin{tabular}{|c|c|c|c|c|c|c|c|c|c|c|c|c|}
\hline Sample ID & \multicolumn{2}{|c|}{ 101-AZ Core \#1 } & \multicolumn{4}{|c|}{ Caustic leach assumed to remove $60 \%$ of $\mathrm{Al}$} & & & & & & \\
\hline & \multirow{2}{*}{\begin{tabular}{|r|} 
Before \\
0.094 \\
\end{tabular}} & & \multicolumn{2}{|c|}{ After Caustic Leach } & & & & & & & & \\
\hline Weight Fraction & & & 0.086 & & & & & & & & & \\
\hline Density & 1.04 & & 1.03 & & & & & & & & & \\
\hline Solids Weight/ Liter & 97.76 & & 88.30 & & & & & & & & & \\
\hline & & & & & & & & & & \multicolumn{3}{|c|}{ After Caustic Leach } \\
\hline Element or Anion & Mole Wt & wt \% & $g / L$ & Moles/L & Wt \% of Solids & Oxide & Mole Wt & \begin{tabular}{|l|}
$\begin{array}{l}\text { Oxide } \\
\text { \%of } \\
\text { Solids }\end{array}$ \\
\end{tabular} & $<$ ? & $\begin{array}{ll}\text { Wt \% of } \\
\text { Solids }\end{array}$ & \begin{tabular}{|l|} 
Oxide wt \\
\%of \\
Solids
\end{tabular} & $\begin{array}{l}\text { microg/g } \\
\text { solids }\end{array}$ \\
\hline $\mathrm{Cd}$ & 112.41 & 0.1040 & 1.0816 & 0.010 & 1.106 & $\mathrm{CdO}$ & 128.409 & 1.264 & & 1.225 & 1.399 & 12249 \\
\hline $\mathrm{Ce}$ & 140.12 & 0.0335 & 0.3484 & 0.002 & 0.356 & $\mathrm{Ce} 2 \mathrm{O} 3$ & 328.238 & 0.417 & & 0.395 & 0.462 & 3945 \\
\hline Co & 58.9332 & 0.0205 & 0.2132 & 0.004 & 0.218 & $\mathrm{Co} 2 \mathrm{O} 3$ & 165.865 & 0.307 & & 0.241 & 0.340 & 2414 \\
\hline $\mathrm{Cr}$ & 51.996 & 0.0465 & 0.4836 & 0.009 & 0.495 & $\mathrm{Cr} 2 \mathrm{O} 3$ & 151.99 & 0.723 & & 0.548 & 0.800 & 5477 \\
\hline $\mathrm{Cu}$ & 63.546 & 0.0080 & 0.0832 & 0.001 & 0.085 & $\mathrm{CuO}$ & 79.5454 & 0.107 & & 0.094 & 0.118 & 942 \\
\hline Dy & 162.5 & 0.0015 & 0.0156 & 0.000 & 0.016 & Dy2O3 & 372.998 & 0.018 & & 0.018 & 0.020 & 177 \\
\hline $\mathrm{Fe}$ & 55.847 & 2.3300 & 24.232 & 0.434 & 24.787 & $\mathrm{Fe} 2 \mathrm{O} 3$ & 159.692 & 35.439 & & 27.441 & 39.234 & 274415 \\
\hline K & 39.0983 & 0.0800 & 0.832 & 0.021 & 0.851 & $\mathrm{~K} 2 \mathrm{O}$ & 94.196 & 1.025 & & 0.942 & 1.135 & 9422 \\
\hline $\mathrm{La}$ & 138.906 & 0.0450 & 0.468 & 0.003 & 0.479 & $\mathrm{La} 2 \mathrm{O} 3$ & 325.809 & 0.561 & & 0.530 & 0.622 & 5300 \\
\hline $\mathrm{Li}$ & 6.941 & 0.0000 & 0 & 0.000 & 0.000 & Li2O & 29.8814 & 0.000 & $<$ & 0.000 & 0.000 & 0 \\
\hline
\end{tabular}




\section{WESTINGHOUSE SAVANNAH RIVER COMPANY}

Hanford Waste Simulants Created to Support Research and

Development on the River Protection Project - Waste Treatment Plant
Report: $\quad$ WSRC-TR-2000-00338

SRT-RPP-2000-00017

Revision (Date): $\quad 0(02 / 22 / 2001)$

\begin{tabular}{|c|c|c|c|c|c|c|c|c|c|c|c|c|}
\hline \multirow{3}{*}{\begin{tabular}{|l} 
Sample ID \\
\\
Weight Fraction \\
\end{tabular}} & \multicolumn{2}{|c|}{ 101-AZ Core \#1 } & \multicolumn{4}{|c|}{ Caustic leach assumed to remove $60 \%$ of $\mathrm{Al}$} & & & & & & \\
\hline & \multirow{2}{*}{\begin{tabular}{|r|} 
Before \\
0.094 \\
\end{tabular}} & & \multicolumn{2}{|c|}{ After Caustic Leach } & & & & & & & & \\
\hline & & & 0.086 & & & & & & & & & \\
\hline Density & 1.04 & & 1.03 & & & & & & & & & \\
\hline Solids Weight/ Liter & 97.76 & & 88.30 & & & & & & & & & \\
\hline & & & & & & & & & & \multicolumn{3}{|c|}{ After Caustic Leach } \\
\hline Element or Anion & Mole Wt & wt \% & $g / L$ & Moles/L & Wt \% of Solids & Oxide & Mole Wt & \begin{tabular}{|l|}
$\begin{array}{l}\text { Oxide } \\
\text { \%of } \\
\text { Solids }\end{array}$ \\
\end{tabular} & $<$ ? & $\begin{array}{l}\text { Wt \% of } \\
\text { Solids }\end{array}$ & \begin{tabular}{|l|}
$\begin{array}{l}\text { Oxide } \\
\text { \%of } \\
\text { Solids }\end{array}$ \\
\end{tabular} & $\begin{array}{l}\text { microg/g } \\
\text { solids }\end{array}$ \\
\hline $\mathrm{Mg}$ & 24.305 & 0.0130 & 0.1352 & 0.006 & 0.138 & $\mathrm{MgO}$ & 40.3044 & 0.229 & & 0.153 & 0.254 & 1531 \\
\hline $\mathrm{Mn}$ & 54.938 & 0.1040 & 1.0816 & 0.020 & 1.106 & $\mathrm{MnO} 2$ & 86.9368 & 1.751 & & 1.225 & 1.938 & 12249 \\
\hline Mo & 95.94 & 0.0020 & 0.0208 & 0.000 & 0.021 & $\mathrm{Mo} 2 \mathrm{O} 3$ & 239.878 & 0.027 & & 0.024 & 0.029 & 236 \\
\hline $\mathrm{Na}$ & 22.9898 & 0.9700 & 10.088 & 0.439 & 10.319 & $\mathrm{Na} 2 \mathrm{O}$ & 61.979 & 13.910 & & 11.424 & 15.399 & 114241 \\
\hline $\mathrm{Nd}$ & 144.24 & 0.0440 & 0.4576 & 0.003 & 0.468 & $\mathrm{Nd} 2 \mathrm{O} 3$ & 336.478 & 0.546 & & 0.518 & 0.604 & 5182 \\
\hline $\mathrm{Ni}$ & 58.69 & 0.0800 & 0.832 & 0.014 & 0.851 & $\mathrm{NiO}$ & 74.6894 & 1.083 & & 0.942 & 1.199 & 9422 \\
\hline $\mathrm{P}$ & 30.9738 & 0.1030 & 1.0712 & 0.035 & 1.096 & $\mathrm{P} 2 \mathrm{O} 5$ & 141.945 & 2.511 & & 1.213 & 2.780 & 12131 \\
\hline $\mathrm{Pb}$ & 207.2 & 0.0725 & 0.754 & 0.004 & 0.771 & $\mathrm{PbO}$ & 223.199 & 0.831 & & 0.854 & 0.920 & 8539 \\
\hline $\operatorname{Re}$ & 186.207 & & 0 & 0.000 & 0.000 & $?$ & 420.412 & 0.000 & $<$ & 0.000 & 0.000 & 0 \\
\hline $\mathrm{Rh}$ & 102.906 & & 0 & 0.000 & 0.000 & $\mathrm{Rh} 2 \mathrm{O} 3$ & 253.809 & 0.000 & $<$ & 0.000 & 0.000 & 0 \\
\hline
\end{tabular}




\section{WESTINGHOUSE SAVANNAH RIVER COMPANY}

Hanford Waste Simulants Created to Support Research and

Development on the River Protection Project - Waste Treatment Plant
Report: $\quad$ WSRC-TR-2000-00338

SRT-RPP-2000-00017

Revision (Date): $\quad 0(02 / 22 / 2001)$

\begin{tabular}{|c|c|c|c|c|c|c|c|c|c|c|c|c|}
\hline \multirow{3}{*}{\begin{tabular}{|l} 
Sample ID \\
\\
Weight Fraction \\
\end{tabular}} & \multicolumn{2}{|c|}{ 101-AZ Core \#1 } & \multicolumn{4}{|c|}{ Caustic leach assumed to remove $60 \%$ of $\mathrm{Al}$} & & & & & & \\
\hline & \multirow{2}{*}{\begin{tabular}{|r|} 
Before \\
0.094 \\
\end{tabular}} & & \multicolumn{2}{|c|}{ After Caustic Leach } & & & & & & & & \\
\hline & & & 0.086 & & & & & & & & & \\
\hline Density & 1.04 & & 1.03 & & & & & & & & & \\
\hline Solids Weight/ Liter & 97.76 & & 88.30 & & & & & & & & & \\
\hline & & & & & & & & & & \multicolumn{3}{|c|}{ After Caustic Leach } \\
\hline Element or Anion & Mole Wt & wt \% & $g / L$ & Moles/L & Wt \% of Solids & Oxide & Mole Wt & \begin{tabular}{|ll} 
Oxide & wt \\
\%of & \\
Solids & \\
\end{tabular} & $<?$ & $\mid \begin{array}{ll}\text { Wt \% } \\
\text { Solids }\end{array}$ & \begin{tabular}{|ll} 
Oxide & wt \\
$\%$ of & \\
Solids & \\
\end{tabular} & $\begin{array}{l}\text { microg/g } \\
\text { solids }\end{array}$ \\
\hline $\mathrm{Ru}$ & 101.07 & & 0 & 0.000 & 0.000 & $\mathrm{Ru} 2 \mathrm{O} 3$ & 250.138 & 0.000 & $<$ & 0.000 & 0.000 & 0 \\
\hline $\mathrm{Sb}$ & 121.75 & & 0 & 0.000 & 0.000 & $\mathrm{Sb} 2 \mathrm{O} 5$ & 323.497 & 0.000 & $<$ & 0.000 & 0.000 & 0 \\
\hline $\mathrm{Se}$ & 78.96 & & 0 & 0.000 & 0.000 & $\mathrm{SeO} 2$ & 110.959 & 0.000 & $<$ & 0.000 & 0.000 & 0 \\
\hline $\mathrm{Si}$ & 28.0855 & 0.1740 & 1.8096 & 0.064 & 1.851 & $\mathrm{SiO} 2$ & 60.0843 & 3.960 & & 2.049 & 4.384 & 20493 \\
\hline $\mathrm{Sr}$ & 87.62 & 0.0105 & 0.1092 & 0.001 & 0.112 & $\mathrm{SrO}$ & 103.619 & 0.132 & & 0.124 & 0.146 & 1237 \\
\hline $\mathrm{Te}$ & 127.6 & & 0 & 0.000 & 0.000 & $\mathrm{TeO} 2$ & 159.599 & 0.000 & $<$ & 0.000 & 0.000 & 0 \\
\hline $\mathrm{Th}$ & 232.038 & 0.0185 & 0.1924 & 0.001 & 0.197 & $\mathrm{ThO} 2$ & 264.037 & 0.224 & & 0.218 & 0.248 & 2179 \\
\hline $\mathrm{Ti}$ & 47.88 & 0.0040 & 0.0416 & 0.001 & 0.043 & $\mathrm{TiO} 2$ & 79.8788 & 0.071 & & 0.047 & 0.079 & 471 \\
\hline $\mathrm{Tl}$ & 204.383 & & 0 & 0.000 & 0.000 & $\mathrm{~T} 12 \mathrm{O} 3$ & 456.764 & 0.000 & $<$ & 0.000 & 0.000 & 0 \\
\hline $\mathrm{U}$ & 238.029 & 0.2950 & 3.068 & 0.013 & 3.138 & UO3 & 286.027 & 3.771 & & 3.474 & 4.175 & 34744 \\
\hline
\end{tabular}




\section{WESTINGHOUSE SAVANNAH RIVER COMPANY}

Hanford Waste Simulants Created to Support Research and

Development on the River Protection Project - Waste Treatment Plant
Report: $\quad$ WSRC-TR-2000-00338

SRT-RPP-2000-00017

Revision (Date): $\quad 0(02 / 22 / 2001)$

\begin{tabular}{|c|c|c|c|c|c|c|c|c|c|c|c|c|}
\hline \multirow{3}{*}{\begin{tabular}{|l} 
Sample ID \\
Weight Fraction \\
\end{tabular}} & \multicolumn{2}{|c|}{ 101-AZ Core \#1 } & \multicolumn{4}{|c|}{ Caustic leach assumed to remove $60 \%$ of $\mathrm{Al}$} & & & & & & \\
\hline & \multirow{2}{*}{\begin{tabular}{|r|} 
Before \\
0.094 \\
\end{tabular}} & & \multicolumn{2}{|c|}{ After Caustic Leach } & & & & & & & & \\
\hline & & & 0.086 & & & & & & & & & \\
\hline Density & 1.04 & & 1.03 & & & & & & & & & \\
\hline Solids Weight/Liter & 97.76 & & 88.30 & & & & & & & & & \\
\hline & & & & & & & & & & \multicolumn{3}{|c|}{ After Caustic Leach } \\
\hline Element or Anion & Mole Wt & wt \% & $g / L$ & Moles/L & Wt \% of Solids & Oxide & Mole Wt & \begin{tabular}{|lr} 
Oxide & wt \\
\%of & \\
Solids & \\
\end{tabular} & $<?$ & $\mid \begin{array}{ll}\text { Wt \% } \\
\text { Solids }\end{array}$ & \begin{tabular}{|ll} 
Oxide & wt \\
\%of & \\
Solids & \\
\end{tabular} & \begin{tabular}{|l} 
microg/g \\
solids
\end{tabular} \\
\hline $\mathrm{V}$ & 50.9415 & & 0 & 0.000 & 0.000 & $\mathrm{~V} 2 \mathrm{O} 3$ & 149.881 & 0.000 & $<$ & 0.000 & 0.000 & 0 \\
\hline $\mathrm{Zn}$ & 65.38 & 0.0135 & 0.1404 & 0.002 & 0.144 & $\mathrm{ZnO}$ & 81.3794 & 0.179 & & 0.159 & 0.198 & 1590 \\
\hline $\mathrm{Zr}$ & 91.22 & 0.5060 & 5.2624 & 0.058 & 5.383 & $\mathrm{ZrO} 2$ & 123.219 & 7.271 & & 5.959 & 8.050 & 59594 \\
\hline NO2- & 46.0055 & 0.4020 & 4.1808 & 0.091 & 4.277 & NO2- & 46.0055 & 4.277 & & 4.735 & 4.735 & 47345 \\
\hline NO3- & 62.0049 & 0.4120 & 4.2848 & 0.069 & 4.383 & NO3- & 62.0049 & 4.383 & & 4.852 & 4.852 & 48523 \\
\hline F- & 18.9984 & 0.0129 & 0.13416 & 0.007 & 0.137 & F- & 18.9984 & 0.137 & & 0.152 & 0.152 & 1519 \\
\hline $\mathrm{Cl}-$ & 35.453 & 0.0032 & 0.03328 & 0.001 & 0.034 & $\mathrm{Cl}-$ & 35.453 & 0.034 & & 0.038 & 0.038 & 377 \\
\hline SO4-2 & 96.0576 & 0.1060 & 1.1024 & 0.011 & 1.128 & SO4-2 & 96.0576 & 1.128 & & 1.248 & 1.248 & 12484 \\
\hline PO4-3 & 78.972 & 0.0160 & 0.1664 & 0.002 & 0.170 & PO4-3 & 78.972 & 0.170 & & 0.188 & 0.188 & 1884 \\
\hline TIC & 12.011 & 0.1300 & 1.352 & 0.113 & 1.383 & TIC & 12.011 & 1.383 & & 1.531 & 1.531 & 15311 \\
\hline
\end{tabular}


Hanford Waste Simulants Created to Support Research and

Development on the River Protection Project - Waste Treatment Plant
Revision (Date): $\begin{array}{rr}\text { SRT-RPP-2000-00017 } \\ 0(02 / 22 / 2001)\end{array}$

Page: $\quad 110$ of 142

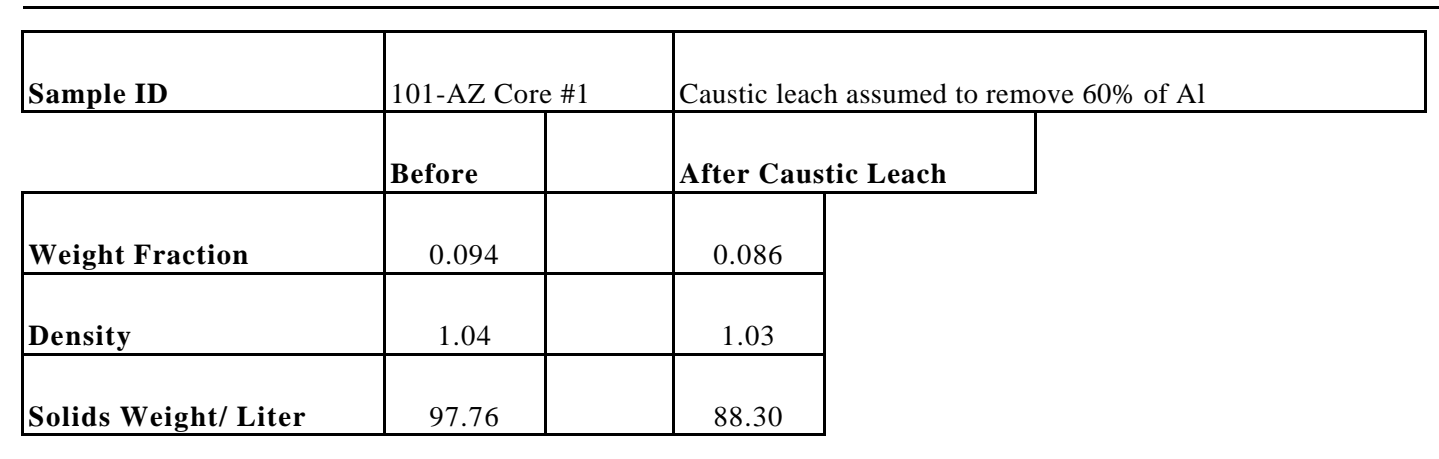

\begin{tabular}{|c|c|c|c|c|c|c|c|c|c|c|c|c|}
\hline & & & & & & & & & & After Caus & tic Leach & \\
\hline Element or Anion & Mole Wt & wt \% & $\mathrm{g} / \mathrm{L}$ & Moles/L & Wt \% of Solids & Oxide & Mole Wt & $\begin{array}{|ll|}\begin{array}{l}\text { Oxide } \\
\text { \%of }\end{array} \\
\text { Solids }\end{array}$ & $<?$ & $\begin{array}{|ll|}\text { Wt \% of } \\
\text { Solids }\end{array}$ & \begin{tabular}{|l|}
$\begin{array}{l}\text { Oxide } \\
\text { \%of } \\
\text { Solids }\end{array}$ \\
\end{tabular} & $\begin{array}{l}\text { microg/g } \\
\text { solids }\end{array}$ \\
\hline $\mathrm{CO} 3-2$ & 60.0092 & 0.6495 & 6.755 & 0.113 & 6.910 & $\mathrm{CO} 3-2$ & 60.0092 & 6.910 & & 7.650 & 7.650 & 76495 \\
\hline Totals & & & 79.53 & & 81.36 & & & 94.76 & & 65.54 & 94.2 & \\
\hline
\end{tabular}




\section{Table 51 Solids Composition for Tank AZ-101 Core \#2}

\begin{tabular}{|c|c|c|}
\hline Sample ID & $\begin{array}{ll}101-A Z & \text { Core } \\
\# 2 & \end{array}$ & Caustic leach assumed \\
\hline & & After Caustic Leach \\
\hline Weight Fraction & 0.186 & 0.178 \\
\hline Density & 1.14 & 1.13 \\
\hline $\begin{array}{ll}\text { Solids } & \text { Weight } / \\
\text { Liter }\end{array}$ & 212.04 & 201.16 \\
\hline
\end{tabular}

\begin{tabular}{|c|c|c|c|c|c|c|c|c|c|c|c|c|}
\hline & & & & & & & & & & $\begin{array}{l}\text { After } \\
\text { Caustic } \\
\text { Ceach }\end{array}$ & & \\
\hline Element or Anion & Mole Wt & wt \% & $\mathrm{g} / \mathrm{L}$ & Moles/L & $\begin{array}{c}\text { Wt \% of } \\
\text { Solids }\end{array}$ & Oxide & Mole Wt & \begin{tabular}{|c|}
$\begin{array}{c}\text { Oxide wt \% of } \\
\text { Solids }\end{array}$ \\
\end{tabular} & $<?$ & $\begin{array}{c}\text { Wt \% of } \\
\text { Solids }\end{array}$ & $\begin{array}{c}\begin{array}{c}\text { Oxide wt \% of } \\
\text { Solids }\end{array} \\
\end{array}$ & $\begin{array}{c}\text { microg/g } \\
\text { solids }\end{array}$ \\
\hline $\mathrm{Ag}$ & 107.8682 & 0.0174 & 0.1984 & 0.002 & 0.094 & $\mathrm{AgO}$ & 123.8676 & 0.107 & & 0.099 & 0.113 & 986 \\
\hline $\mathrm{Al}$ & 26.98154 & 0.8420 & 9.5988 & 0.356 & 4.527 & $\mathrm{Al} 2 \mathrm{O} 3$ & 101.96128 & 8.553 & & 1.909 & 3.606 & 19087 \\
\hline As & 74.9216 & 0.0240 & 0.2736 & 0.004 & 0.129 & As2O3 & 197.8414 & 0.170 & $<$ & 0.136 & 0.180 & 1360 \\
\hline B & 10.81 & 0.0200 & 0.2280 & 0.021 & 0.108 & B2O3 & 69.6182 & 0.346 & $<$ & 0.113 & 0.365 & 1133 \\
\hline $\mathrm{Ba}$ & 137.33 & 0.0435 & 0.4959 & 0.004 & 0.234 & $\mathrm{BaO}$ & 153.3294 & 0.261 & & 0.247 & 0.275 & 2465 \\
\hline $\mathrm{Be}$ & 9.01218 & 0.0041 & 0.0467 & 0.005 & 0.022 & $\mathrm{BeO}$ & 25.01158 & 0.031 & & 0.023 & 0.064 & 232 \\
\hline
\end{tabular}




\section{WESTINGHOUSE SAVANNAH RIVER COMPANY}

Hanford Waste Simulants Created to Support Research and

Development on the River Protection Project - Waste Treatment Plant
Report: $\quad$ WSRC-TR-2000-00338

SRT-RPP-2000-00017

Revision (Date): $\quad 0(02 / 22 / 2001)$

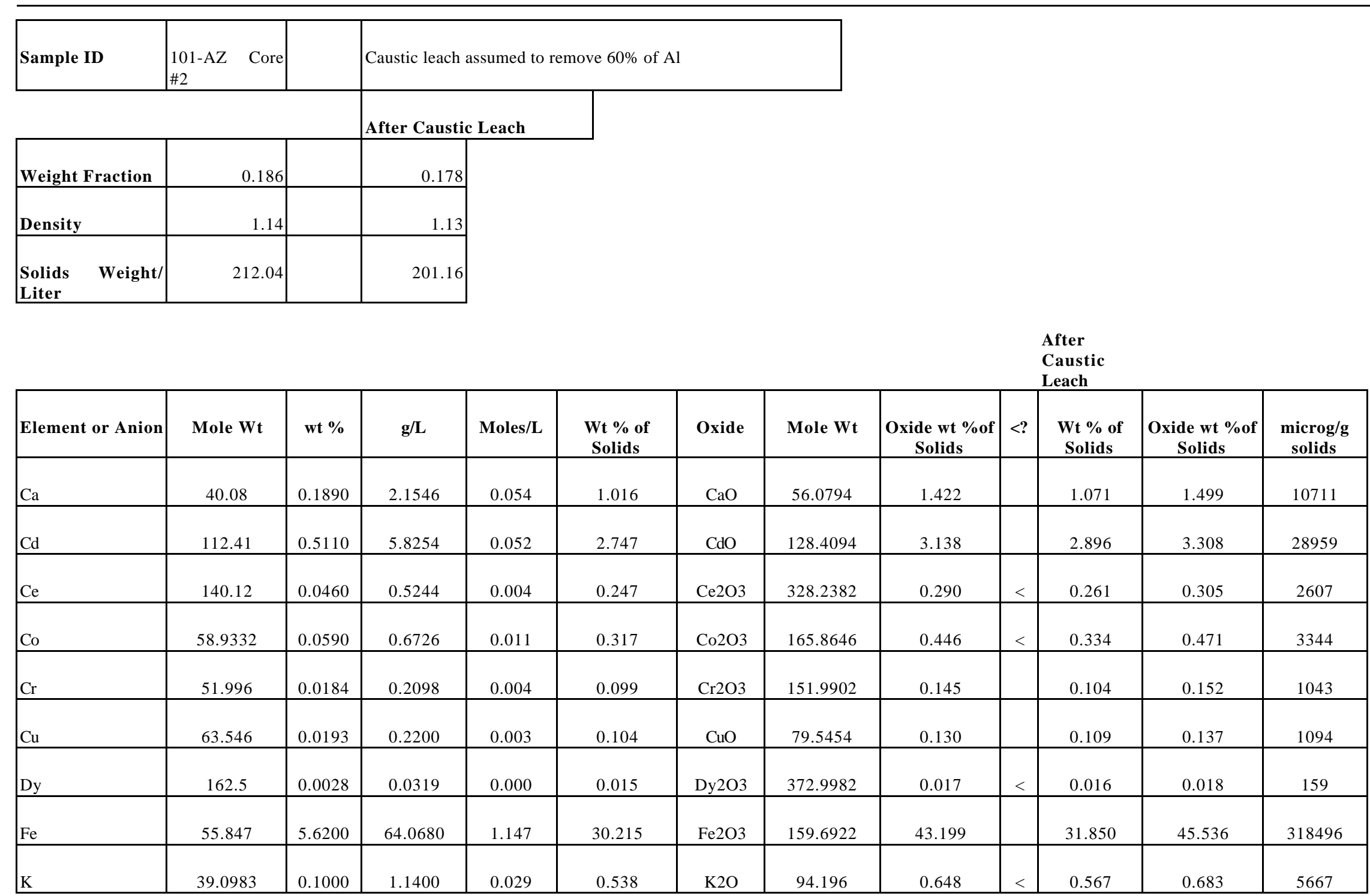




\section{WESTINGHOUSE SAVANNAH RIVER COMPANY}

Hanford Waste Simulants Created to Support Research and

Development on the River Protection Project - Waste Treatment Plant
Report: $\quad$ WSRC-TR-2000-00338

SRT-RPP-2000-00017

Revision (Date): $\quad 0(02 / 22 / 2001)$

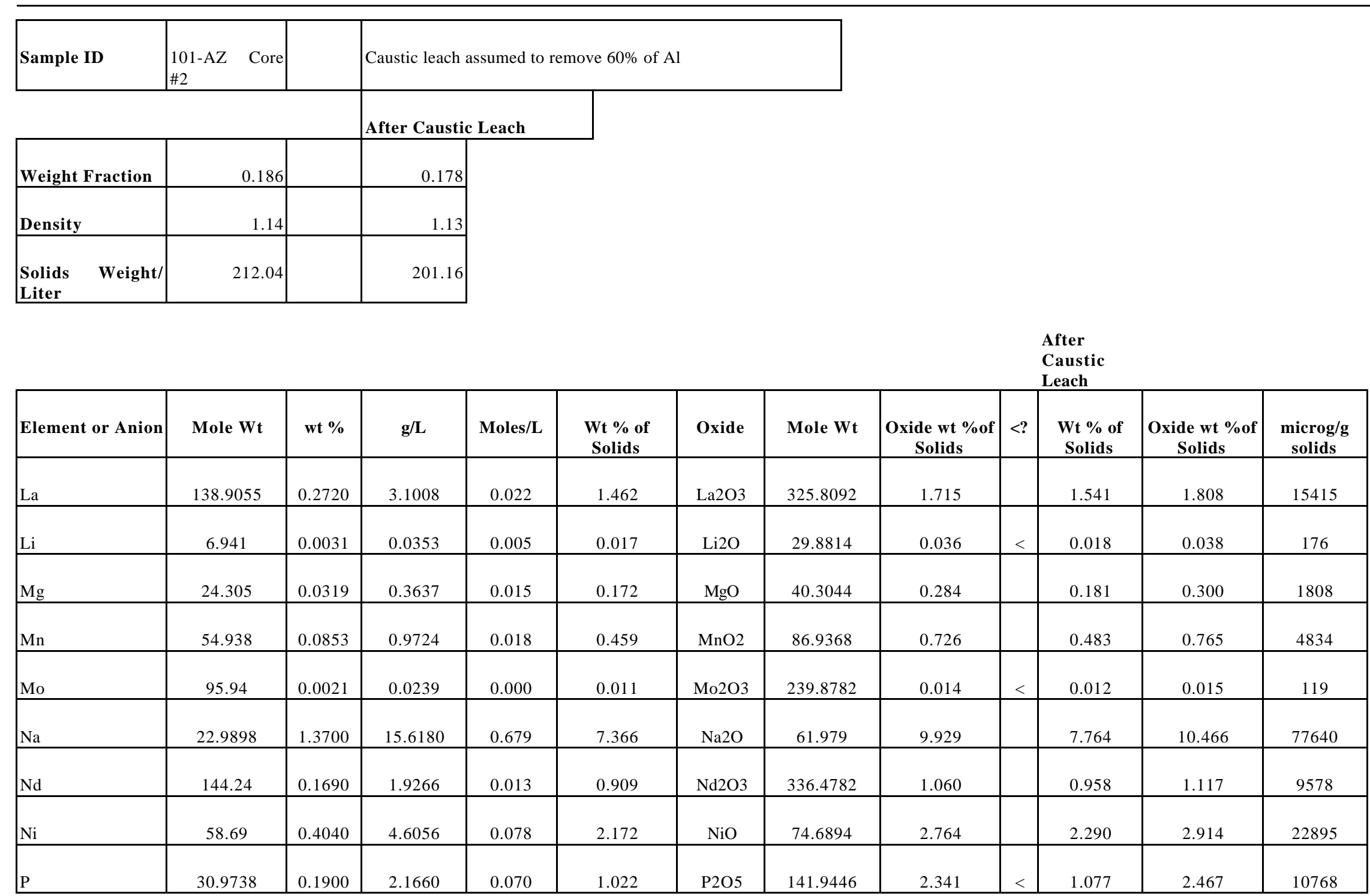




\section{WESTINGHOUSE SAVANNAH RIVER COMPANY}

Hanford Waste Simulants Created to Support Research and

Development on the River Protection Project - Waste Treatment Plant
Report: $\quad$ WSRC-TR-2000-00338

SRT-RPP-2000-00017

Revision (Date): $\quad 0(02 / 22 / 2001)$

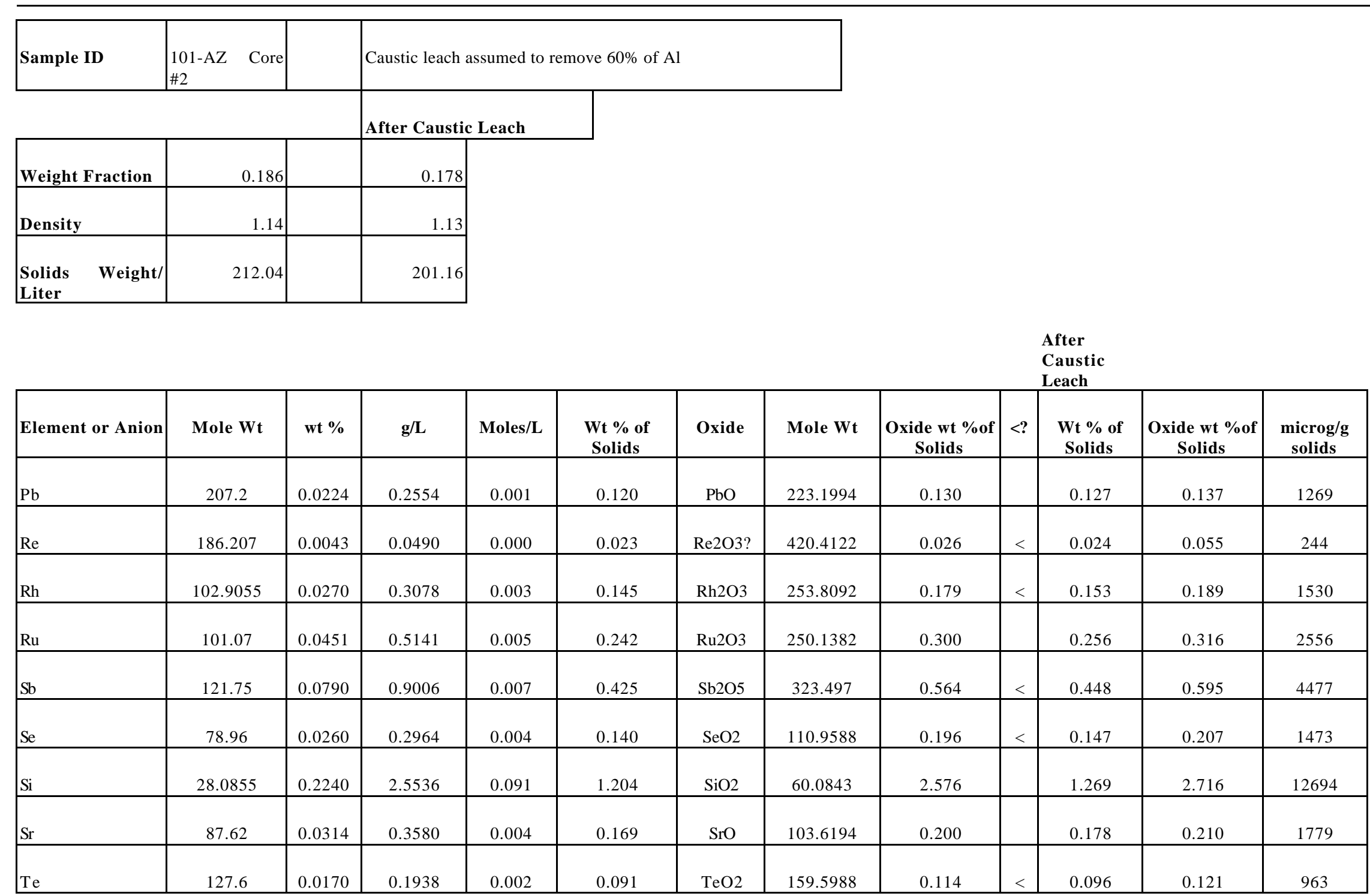




\section{WESTINGHOUSE SAVANNAH RIVER COMPANY}

Hanford Waste Simulants Created to Support Research and

Development on the River Protection Project - Waste Treatment Plant
Report: $\quad$ WSRC-TR-2000-00338

SRT-RPP-2000-00017

Revision (Date): $\quad 0(02 / 22 / 2001)$

Page: $\quad 115$ of 142

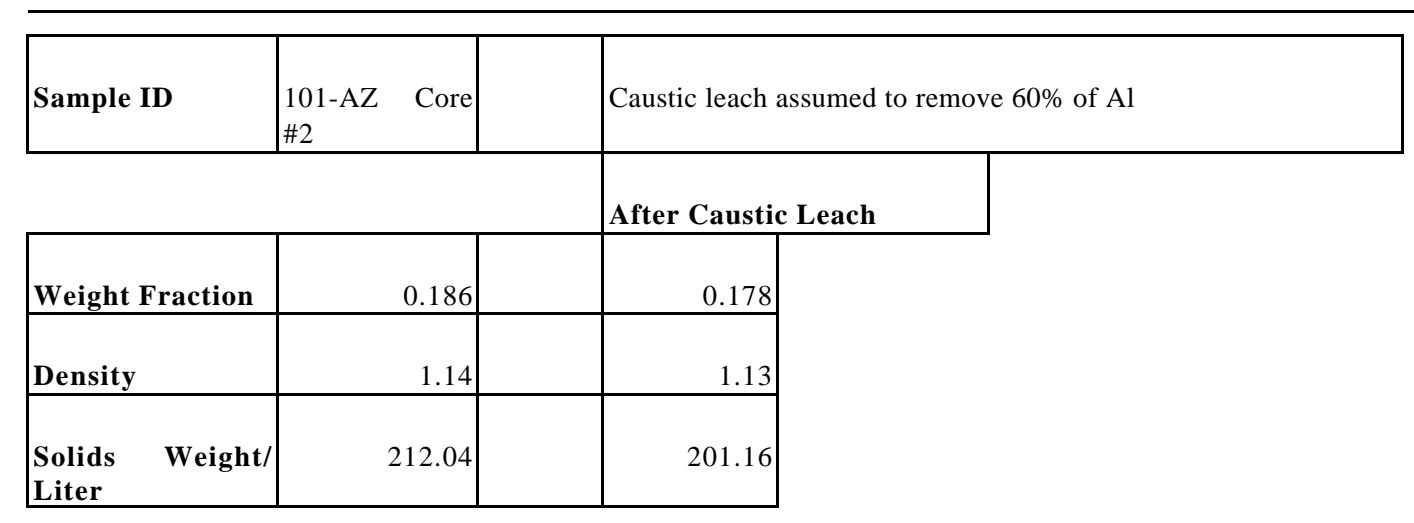

\begin{tabular}{|c|c|c|c|c|c|c|c|c|c|c|c|c|}
\hline & & & & & & & & & & $\begin{array}{l}\text { After } \\
\text { Caustic } \\
\text { Leach }\end{array}$ & & \\
\hline Element or Anion & Mole Wt & wt \% & $\mathrm{g} / \mathrm{L}$ & Moles/L & $\begin{array}{c}\text { Wt \% of } \\
\text { Solids }\end{array}$ & Oxide & Mole Wt & \begin{tabular}{|c|} 
Oxide wt \% of \\
Solids
\end{tabular} & $<?$ & $\begin{array}{l}\text { Wt \% of } \\
\text { Solids }\end{array}$ & $\begin{array}{c}\text { Oxide wt \% of } \\
\text { Solids }\end{array}$ & $\begin{array}{c}\text { microg/g } \\
\text { solids }\end{array}$ \\
\hline $\mathrm{Th}$ & 232.0381 & 0.0330 & 0.3762 & 0.002 & 0.177 & ThO2 & 264.0369 & 0.202 & $<$ & 0.187 & 0.213 & 1870 \\
\hline $\mathrm{Ti}$ & 47.88 & 0.0038 & 0.0433 & 0.001 & 0.020 & $\mathrm{TiO} 2$ & 79.8788 & 0.034 & & 0.022 & 0.036 & 215 \\
\hline $\mathrm{Tl}$ & 204.383 & 0.4200 & 4.7880 & 0.023 & 2.258 & $\mathrm{~T} 12 \mathrm{O} 3$ & 456.7642 & 2.523 & $<$ & 2.380 & 2.660 & 23802 \\
\hline $\mathrm{U}$ & 238.0289 & 0.4050 & 4.6170 & 0.019 & 2.177 & UO3 & 286.0271 & 2.616 & & 2.295 & 2.758 & 22952 \\
\hline $\mathrm{V}$ & 50.9415 & 0.0024 & 0.0274 & 0.001 & 0.013 & $\mathrm{~V} 2 \mathrm{O} 3$ & 149.8812 & 0.019 & $<$ & 0.014 & 0.020 & 136 \\
\hline $\mathrm{Zn}$ & 65.38 & 0.0112 & 0.1277 & 0.002 & 0.060 & $\mathrm{ZnO}$ & 81.3794 & 0.075 & & 0.063 & 0.079 & 635 \\
\hline $\mathrm{Zr}$ & 91.22 & 2.1300 & 24.2820 & 0.266 & 11.452 & $\mathrm{ZrO} 2$ & 123.2188 & 15.469 & & 12.071 & 16.305 & 120711 \\
\hline NO2- & 46.0055 & 0.6100 & 6.9540 & 0.151 & 3.280 & NO2- & 46.0055 & 3.280 & & 3.457 & 3.457 & 34570 \\
\hline NO3- & 62.0049 & 0.3100 & 3.5340 & 0.057 & 1.667 & NO3- & 62.0049 & 1.667 & & 1.757 & 1.757 & 17568 \\
\hline
\end{tabular}


Hanford Waste Simulants Created to Support Research and

Development on the River Protection Project - Waste Treatment Plant
SRT-RPP-2000-00017

Revision (Date): $\quad 0(02 / 22 / 2001)$

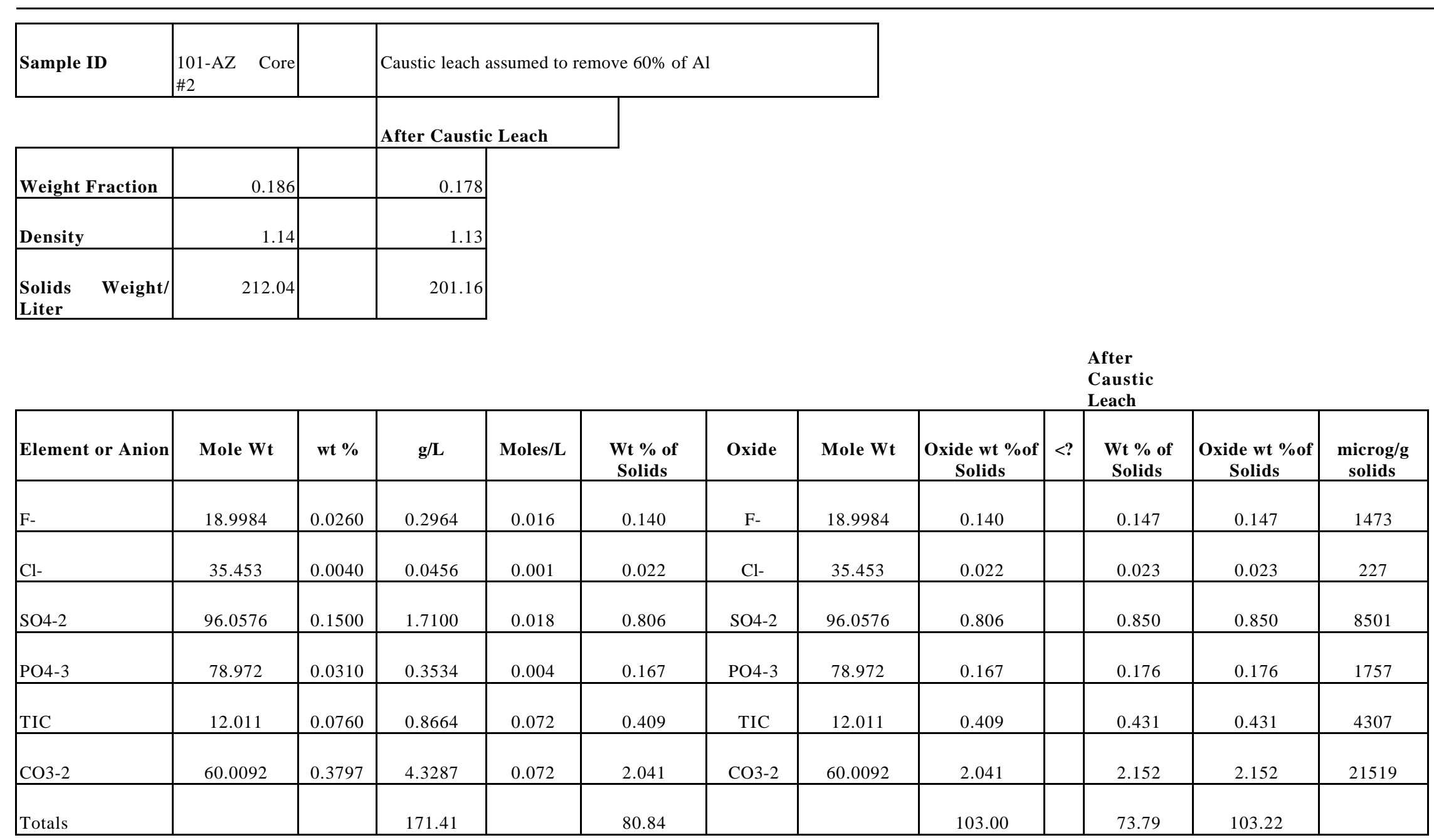


Table 52 Tank AZ-101 Blend Solids Composition

\begin{tabular}{|c|c|c|c|c|c|}
\hline Tank & AZ-101 & AZ-101 & Blend & Blend & Blend \\
\hline Volume, Gallons & 35000 & 35000 & 35000 & & \\
\hline Volume, Liters & 132489 & 132489 & 132489 & & \\
\hline Weight Fraction & 0.094 & 0.186 & 0.142 & & \\
\hline Density & 1.040 & 1.140 & 1.090 & & \\
\hline Solids Weight/ Liter & 97.760 & 212.040 & 154.900 & & \\
\hline Element or Anion & grams/Liter & grams/Liter & grams/Liter & grams/gram solids & microgram/gram \\
\hline $\mathrm{Ag}$ & 0.494 & 0.198 & 0.346 & 2.23E-03 & 2235 \\
\hline $\mathrm{Al}$ & 8.341 & 9.599 & 8.970 & 5.79E-02 & 57907 \\
\hline As & 0.395 & 0.274 & 0.334 & $2.16 \mathrm{E}-03$ & 2159 \\
\hline B & 0.021 & 0.228 & 0.124 & 8.03E-04 & 803 \\
\hline $\mathrm{Ba}$ & 0.159 & 0.496 & 0.328 & $2.11 \mathrm{E}-03$ & 2114 \\
\hline $\mathrm{Be}$ & 0.000 & 0.047 & 0.023 & $1.51 \mathrm{E}-04$ & 151 \\
\hline
\end{tabular}




\begin{tabular}{|c|c|c|c|c|c|c|}
\hline Tank & AZ-101 & AZ-101 & Blend & Blend & Blend & \\
\hline Volume, Gallons & 35000 & 35000 & 35000 & & & \\
\hline Volume, Liters & 132489 & 132489 & 132489 & & & \\
\hline Weight Fraction & 0.094 & 0.186 & 0.142 & & & \\
\hline Density & 1.040 & 1.140 & 1.090 & & & \\
\hline Solids Weight/ Liter & 97.760 & 212.040 & 154.900 & & & \\
\hline Element or Anion & grams/Liter & grams/Liter & grams/Liter & grams/gram solids & microgram/gram & $<?$ \\
\hline $\mathrm{Ca}$ & 0.645 & 2.155 & 1.400 & 9.04E-03 & 9036 & \\
\hline $\mathrm{Cd}$ & 1.082 & 5.825 & 3.454 & 2.23E-02 & 22295 & \\
\hline $\mathrm{Ce}$ & 0.348 & 0.524 & 0.436 & $2.82 \mathrm{E}-03$ & 2817 & \\
\hline $\mathrm{Co}$ & 0.213 & 0.673 & 0.443 & $2.86 \mathrm{E}-03$ & 2859 & $<$ \\
\hline $\mathrm{Cr}$ & 0.484 & 0.210 & 0.347 & $2.24 \mathrm{E}-03$ & 2238 & \\
\hline $\mathrm{Cu}$ & 0.083 & 0.220 & 0.152 & 9.79E-04 & 979 & \\
\hline Dy & 0.016 & 0.032 & 0.024 & $1.53 \mathrm{E}-04$ & 153 & $<$ \\
\hline $\mathrm{Fe}$ & 24.232 & 64.068 & 44.150 & $2.85 \mathrm{E}-01$ & 285023 & \\
\hline
\end{tabular}




\begin{tabular}{|c|c|c|c|c|c|c|}
\hline Tank & AZ-101 & AZ-101 & Blend & Blend & Blend & \\
\hline Volume, Gallons & 35000 & 35000 & 35000 & & & \\
\hline Volume, Liters & 132489 & 132489 & 132489 & & & \\
\hline Weight Fraction & 0.094 & 0.186 & 0.142 & & & \\
\hline Density & 1.040 & 1.140 & 1.090 & & & \\
\hline Solids Weight/ Liter & 97.760 & 212.040 & 154.900 & & & \\
\hline Element or Anion & grams/Liter & grams/Liter & grams/Liter & grams/gram solids & microgram/gram & $<?$ \\
\hline K & 0.832 & 1.140 & 0.986 & $6.37 \mathrm{E}-03$ & 6365 & $<$ \\
\hline $\mathrm{La}$ & 0.468 & 3.101 & 1.784 & $1.15 \mathrm{E}-02$ & 11520 & \\
\hline $\mathrm{Li}$ & 0.000 & 0.035 & 0.018 & $1.14 \mathrm{E}-04$ & 114 & \\
\hline $\mathrm{Mg}$ & 0.135 & 0.364 & 0.249 & $1.61 \mathrm{E}-03$ & 1610 & \\
\hline $\mathrm{Mn}$ & 1.082 & 0.972 & 1.027 & $6.63 \mathrm{E}-03$ & 6630 & \\
\hline Mo & 0.021 & 0.024 & 0.022 & $1.44 \mathrm{E}-04$ & 144 & \\
\hline $\mathrm{Na}$ & 10.088 & 15.618 & 12.853 & 8.30E-02 & 82976 & \\
\hline $\mathrm{Nd}$ & 0.458 & 1.927 & 1.192 & 7.70E-03 & 7696 & \\
\hline
\end{tabular}




\begin{tabular}{|c|c|c|c|c|c|c|}
\hline Tank & AZ-101 & AZ-101 & Blend & Blend & Blend & \\
\hline Volume, Gallons & 35000 & 35000 & 35000 & & & \\
\hline Volume, Liters & 132489 & 132489 & 132489 & & & \\
\hline Weight Fraction & 0.094 & 0.186 & 0.142 & & & \\
\hline Density & 1.040 & 1.140 & 1.090 & & & \\
\hline Solids Weight/ Liter & 97.760 & 212.040 & 154.900 & & & \\
\hline Element or Anion & grams/Liter & grams/Liter & grams/Liter & grams/gram solids & microgram/gram & $<?$ \\
\hline $\mathrm{Ni}$ & 0.832 & 4.606 & 2.719 & $1.76 \mathrm{E}-02$ & 17552 & \\
\hline $\mathrm{P}$ & 1.071 & 2.166 & 1.619 & $1.04 \mathrm{E}-02$ & 10449 & $<$ \\
\hline $\mathrm{Pb}$ & 0.754 & 0.255 & 0.505 & $3.26 \mathrm{E}-03$ & 3258 & $<$ \\
\hline $\mathrm{Re}$ & 0.000 & 0.049 & 0.025 & $1.58 \mathrm{E}-04$ & 158 & $<$ \\
\hline $\mathrm{Rh}$ & 0.000 & 0.308 & 0.154 & 9.94E-04 & 994 & $<$ \\
\hline $\mathrm{Ru}$ & 0.000 & 0.514 & 0.257 & $1.66 \mathrm{E}-03$ & 1660 & \\
\hline $\mathrm{Sb}$ & 0.000 & 0.901 & 0.450 & 2.91E-03 & 2907 & $<$ \\
\hline $\mathrm{Se}$ & 0.000 & 0.296 & 0.148 & $9.57 \mathrm{E}-04$ & 957 & $<$ \\
\hline
\end{tabular}




\begin{tabular}{|c|c|c|c|c|c|c|}
\hline Tank & AZ-101 & AZ-101 & Blend & Blend & Blend & \\
\hline Volume, Gallons & 35000 & 35000 & 35000 & & & \\
\hline Volume, Liters & 132489 & 132489 & 132489 & & & \\
\hline Weight Fraction & 0.094 & 0.186 & 0.142 & & & \\
\hline Density & 1.040 & 1.140 & 1.090 & & & \\
\hline Solids Weight/ Liter & 97.760 & 212.040 & 154.900 & & & \\
\hline Element or Anion & grams/Liter & grams/Liter & grams/Liter & grams/gram solids & microgram/gram & $<?$ \\
\hline $\mathrm{Si}$ & 1.810 & 2.554 & 2.182 & $1.41 \mathrm{E}-02$ & 14084 & \\
\hline $\mathrm{Sr}$ & 0.109 & 0.358 & 0.234 & $1.51 \mathrm{E}-03$ & 1508 & \\
\hline $\mathrm{Te}$ & 0.000 & 0.194 & 0.097 & $6.26 \mathrm{E}-04$ & 626 & $<$ \\
\hline Th & 0.192 & 0.376 & 0.284 & $1.84 \mathrm{E}-03$ & 1835 & $<$ \\
\hline $\mathrm{Ti}$ & 0.042 & 0.043 & 0.042 & 2.74E-04 & 274 & \\
\hline $\mathrm{Tl}$ & 0.000 & 4.788 & 2.394 & $1.55 \mathrm{E}-02$ & 15455 & $<$ \\
\hline $\mathrm{U}$ & 3.068 & 4.617 & 3.843 & $2.48 \mathrm{E}-02$ & 24806 & $<$ \\
\hline V & 0.000 & 0.027 & 0.014 & 8.83E-05 & 88 & $<$ \\
\hline
\end{tabular}




\begin{tabular}{|c|c|c|c|c|c|c|}
\hline Tank & AZ-101 & AZ-101 & Blend & Blend & Blend & \\
\hline Volume, Gallons & 35000 & 35000 & 35000 & & & \\
\hline Volume, Liters & 132489 & 132489 & 132489 & & & \\
\hline Weight Fraction & 0.094 & 0.186 & 0.142 & & & \\
\hline Density & 1.040 & 1.140 & 1.090 & & & \\
\hline Solids Weight/ Liter & 97.760 & 212.040 & 154.900 & & & \\
\hline Element or Anion & grams/Liter & grams/Liter & grams/Liter & grams/gram solids & microgram/gram & $<?$ \\
\hline $\mathrm{Zn}$ & 0.140 & 0.128 & 0.134 & 8.65E-04 & 865 & \\
\hline $\mathrm{Zr}$ & 5.262 & 24.282 & 14.772 & $9.54 \mathrm{E}-02$ & 95366 & \\
\hline NO2- & 4.181 & 6.954 & 5.567 & $3.59 \mathrm{E}-02$ & 35942 & \\
\hline NO3- & 4.285 & 3.534 & 3.909 & 2.52E-02 & 25238 & \\
\hline F- & 0.134 & 0.296 & 0.215 & $1.39 \mathrm{E}-03$ & 1390 & \\
\hline $\mathrm{Cl}-$ & 0.033 & 0.046 & 0.039 & 2.55E-04 & 255 & $<$ \\
\hline SO4-2 & 1.102 & 1.710 & 1.406 & $9.08 \mathrm{E}-03$ & 9078 & $<$ \\
\hline PO4-3 & 0.166 & 0.353 & 0.260 & $1.68 \mathrm{E}-03$ & 1678 & $<$ \\
\hline
\end{tabular}




\begin{tabular}{|c|c|c|c|c|c|c|}
\hline Tank & AZ-101 & AZ-101 & Blend & Blend & Blend & \\
\hline Volume, Gallons & 35000 & 35000 & 35000 & & & \\
\hline Volume, Liters & 132489 & 132489 & 132489 & & & \\
\hline Weight Fraction & 0.094 & 0.186 & 0.142 & & & \\
\hline Density & 1.040 & 1.140 & 1.090 & & & \\
\hline Solids Weight/ Liter & 97.760 & 212.040 & 154.900 & & & \\
\hline Element or Anion & grams/Liter & grams/Liter & grams/Liter & grams/gram solids & microgram/gram & $<?$ \\
\hline TIC & 1.352 & 0.866 & 1.109 & $7.16 \mathrm{E}-03$ & 7161 & \\
\hline $\mathrm{CO} 3-2$ & 6.755 & 4.329 & 5.542 & $3.58 \mathrm{E}-02$ & 35776 & \\
\hline
\end{tabular}


Table 53 Compound Calculations for AZ-101 Simulated Sludge

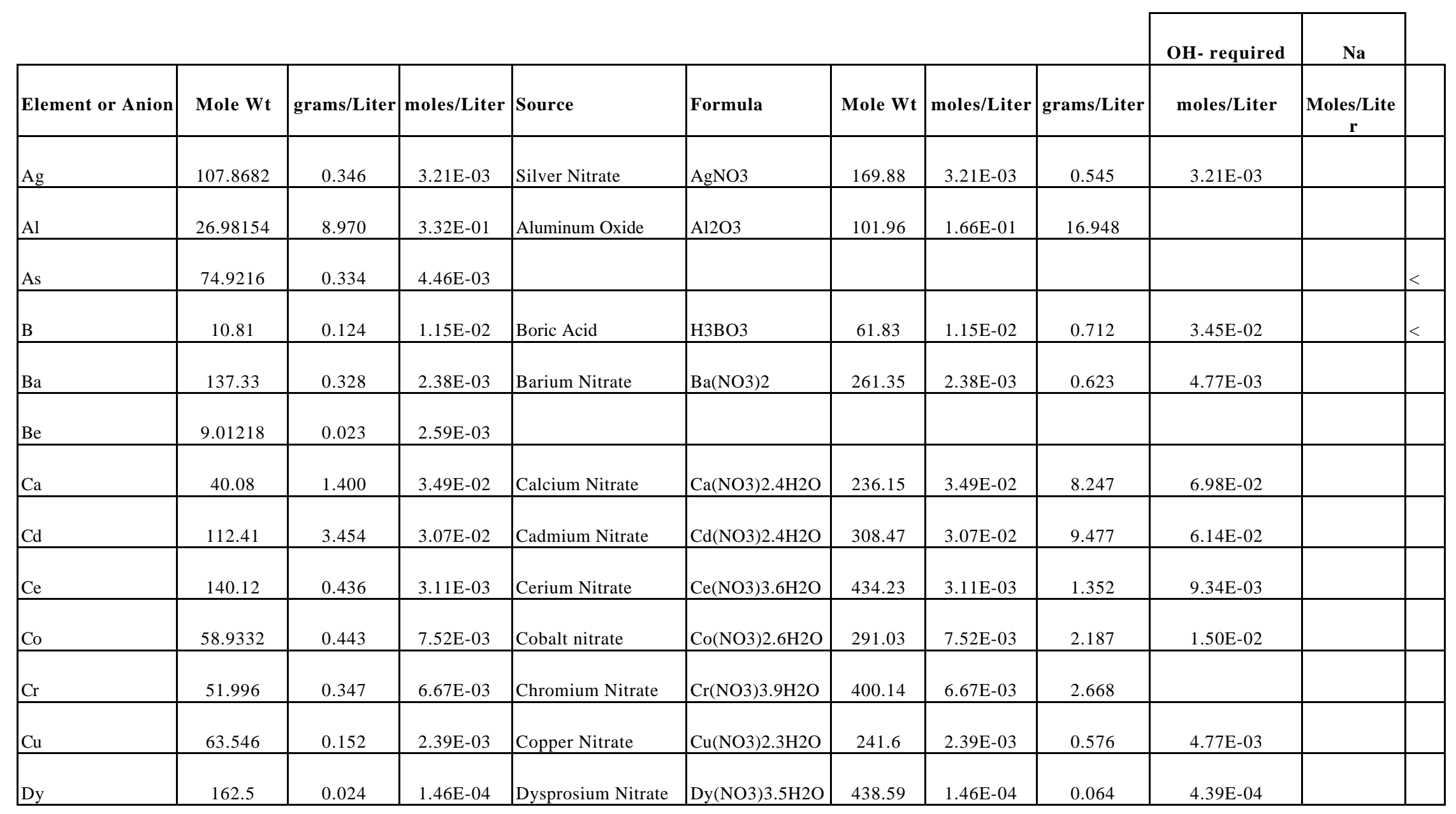




\section{WESTINGHOUSE SAVANNAH RIVER COMPANY}

Hanford Waste Simulants Created to Support Research and

Development on the River Protection Project - Waste Treatment Plant
Report: $\quad$ WSRC-TR-2000-00338

SRT-RPP-2000-00017

Revision (Date): $\quad 0(02 / 22 / 2001)$

Page: $\quad 125$ of 142

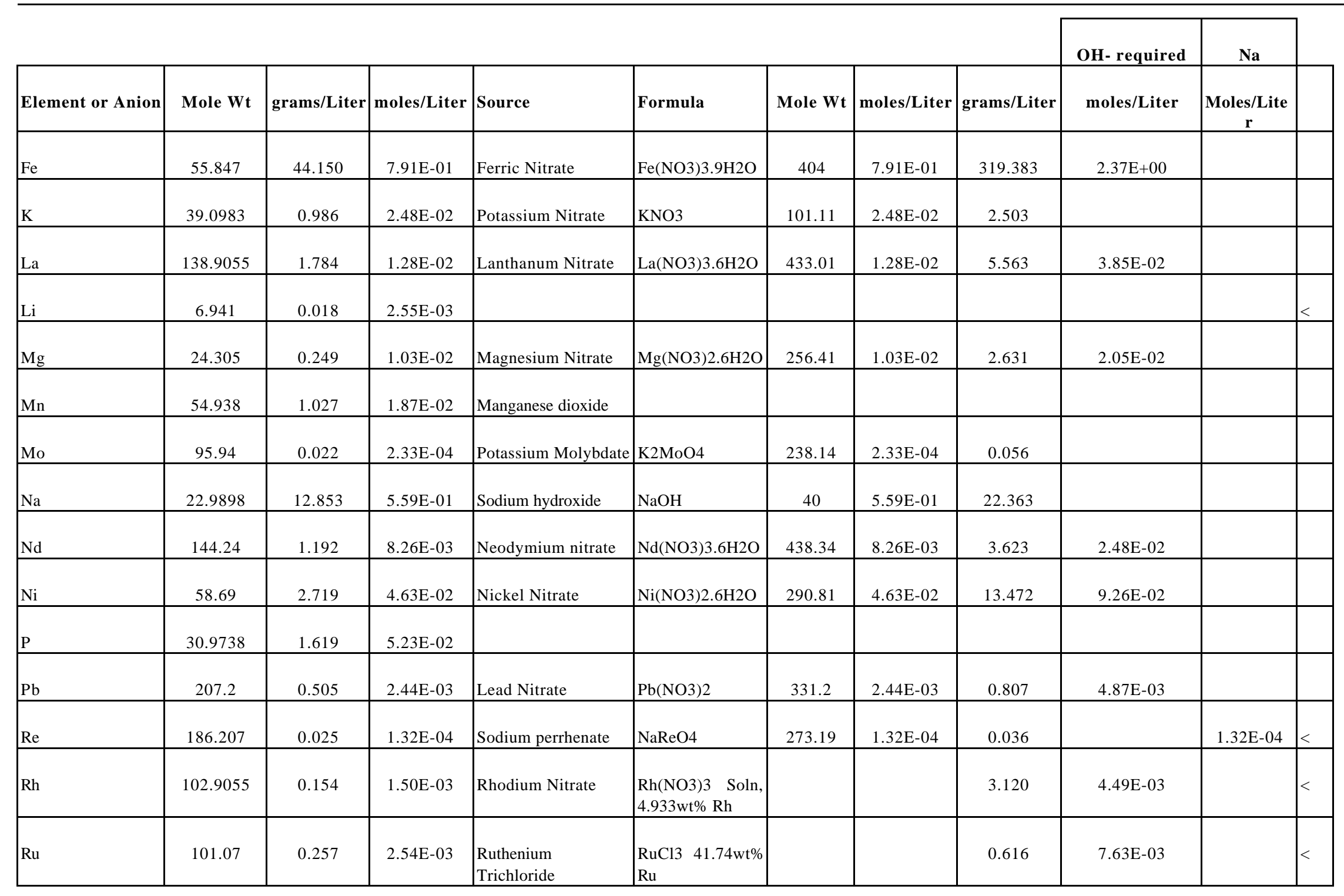




\section{WESTINGHOUSE SAVANNAH RIVER COMPANY}

Hanford Waste Simulants Created to Support Research and

Development on the River Protection Project - Waste Treatment Plant
Report: $\quad$ WSRC-TR-2000-00338

SRT-RPP-2000-00017

Revision (Date): $\quad 0(02 / 22 / 2001)$

Page: $\quad 126$ of 142

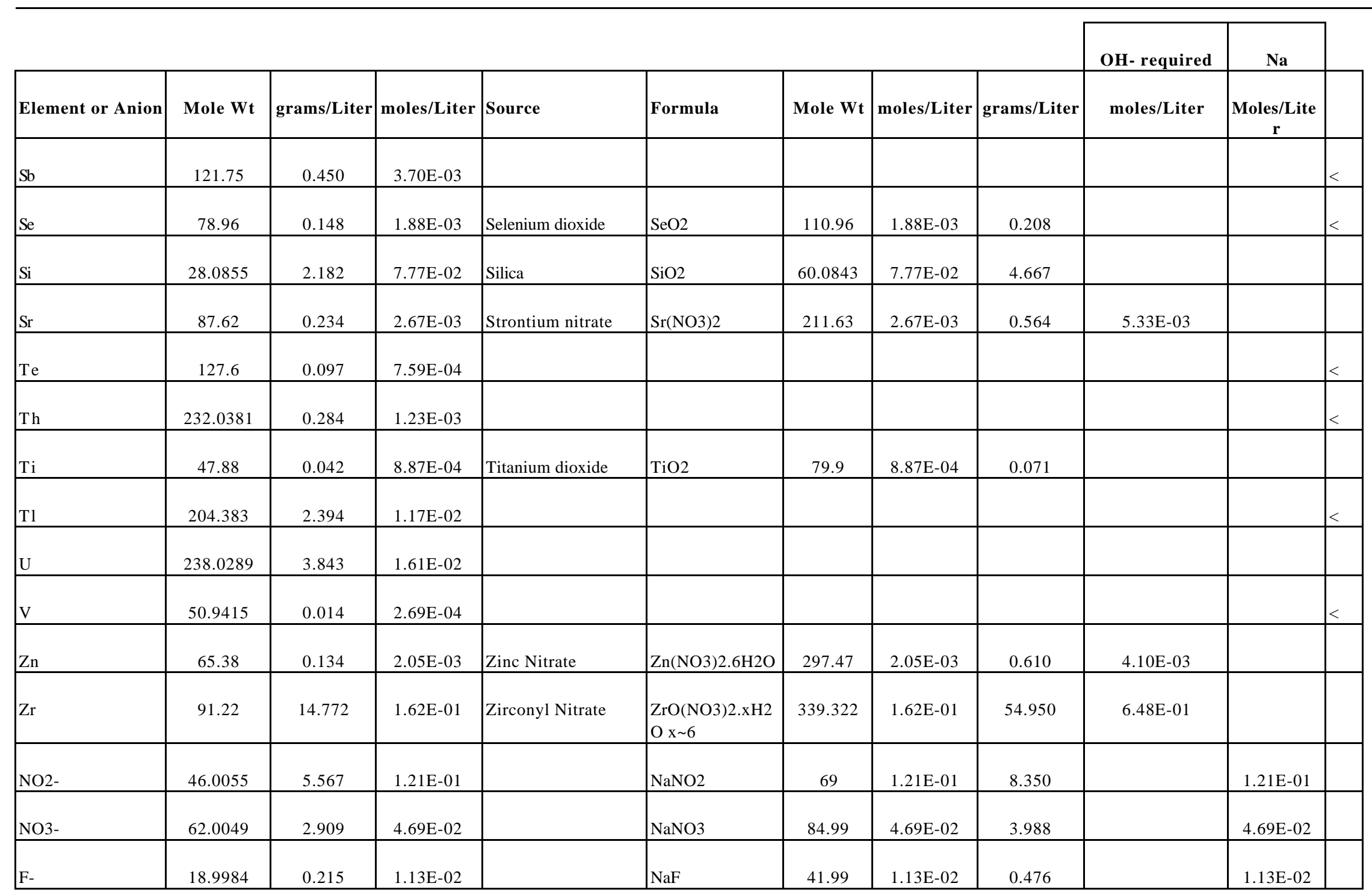




\section{WESTINGHOUSE SAVANNAH RIVER COMPANY}

Hanford Waste Simulants Created to Support Research and

Development on the River Protection Project - Waste Treatment Plant
Report: $\quad$ WSRC-TR-2000-00338

SRT-RPP-2000-00017

Revision (Date): $\quad 0(02 / 22 / 2001)$

\begin{tabular}{|c|c|c|c|c|c|c|c|c|c|c|}
\hline & & & & & & & & & OH- required & $\mathbf{N a}$ \\
\hline Element or Anion & Mole Wt & grams/Liter & moles/Liter & Source & Formula & Mole Wt & moles/Liter & grams/Liter & moles/Liter & \begin{tabular}{|c} 
Moles/Lite \\
$\mathbf{r}$ \\
\end{tabular} \\
\hline $\mathrm{Cl}-$ & 35.453 & 0.039 & $1.11 \mathrm{E}-03$ & & $\mathrm{NaCl}$ & 58.44 & $1.11 \mathrm{E}-03$ & 0.065 & & $1.11 \mathrm{E}-03$ \\
\hline $\mathrm{SO} 4-2$ & 96.0576 & 1.406 & $1.46 \mathrm{E}-02$ & & $\mathrm{Na} 2 \mathrm{SO} 4$ & 142.04 & $1.46 \mathrm{E}-02$ & 2.079 & & $2.93 \mathrm{E}-02$ \\
\hline $\mathrm{PO} 4-3$ & 78.972 & 4.127 & $5.23 \mathrm{E}-02$ & & $\mathrm{Na} 3 \mathrm{PO} 4.12 \mathrm{H} 2 \mathrm{O}$ & 380.12 & $5.23 \mathrm{E}-02$ & 19.864 & & $1.57 \mathrm{E}-01$ \\
\hline TIC & 12.011 & 1.109 & $9.23 \mathrm{E}-02$ & & & & & & & \\
\hline $\mathrm{CO} 3-2$ & 60.0092 & 5.542 & $9.23 \mathrm{E}-02$ & & $\mathrm{Na} 2 \mathrm{CO} 3$ & 105.99 & $9.23 \mathrm{E}-02$ & 9.788 & & $1.85 \mathrm{E}-01$ \\
\hline & & & & & & & & Totals & $3.43 \mathrm{E}+00$ & $5.51 \mathrm{E}-01$ \\
\hline & & & & & & & & Total-CO3 & & 3.67E-01 \\
\hline
\end{tabular}

Manganese Dioxide

Calculations

\begin{tabular}{|l|c|} 
& Moles/Liter \\
\hline Mn needed & $1.87 \mathrm{E}-02$ \\
\hline
\end{tabular}

Stoichiometry

$3 \mathrm{Mn}(\mathrm{NO} 3) 2+2 \mathrm{KMnO} 4+2 \mathrm{H} 2 \mathrm{O}=2 \mathrm{KNO} 3+5 \mathrm{MnO} 2+4 \mathrm{HNO} 3$

\begin{tabular}{l|l|} 
Mole Wt & grams/Liter \\
\hline
\end{tabular} 


\section{WESTINGHOUSE SAVANNAH RIVER COMPANY}

Hanford Waste Simulants Created to Support Research and Development on the River Protection Project - Waste Treatment Plant
Report: $\quad$ WSRC-TR-2000-00338 SRT-RPP-2000-00017

Revision (Date): $\quad 0(02 / 22 / 2001)$

\begin{tabular}{|c|c|c|c|c|c|c|c|c|c|c|}
\hline & & & & & & & & & OH- required & $\mathbf{N a}$ \\
\hline Element or Anion & Mole Wt & grams/Liter & moles/Liter & Source & Formula & Mole Wt & moles/Liter & grams/Liter & moles/Liter & $\begin{array}{c}\text { Moles/Lite } \\
\mathbf{r}\end{array}$ \\
\hline $\mathrm{Mn}(\mathrm{NO} 3) 2$ & $1.12 \mathrm{E}-02$ & 178.95 & 2.01 & $50 \mathrm{wt} \% \mathrm{Mn}(\mathrm{NO} 3) 2$ & \begin{tabular}{|ll}
50 & $\mathrm{wt} \%$ \\
$\mathrm{Mn}(\mathrm{NO} 3) 2$ & \\
\end{tabular} & 178.95 & $1.12 \mathrm{E}-02$ & 4.014 & & \\
\hline $\mathrm{KMnO} 4$ & $7.48 \mathrm{E}-03$ & 158.03 & 1.18 & \begin{tabular}{|l} 
Potassium \\
Permanganate
\end{tabular} & $\mathrm{KMnO} 4$ & 158.03 & $7.48 \mathrm{E}-03$ & 1.182 & & \\
\hline
\end{tabular}


Table 54 Final Simulated Sludge Recipe for Envelope D Waste

Simulated Sludge Recipe AZ-101

Volume of Feed

$1000 \mathrm{~mL}$

\begin{tabular}{|l|l|l|}
\cline { 2 - 3 } \multicolumn{1}{c|}{} & grams & Actual Wt, grams \\
\hline Water & & \\
\hline
\end{tabular}

Manganese Dioxide Production

Add to the kettle:

\begin{tabular}{|l|l|l|l|}
\hline Compounds & Formula & Mass Needed & Actual Wt, grams \\
\hline Potassium Permanganate & KMnO4 & 1.18 & \\
\hline
\end{tabular}

Compound should completely dissolve.

Add to the kettle:

\begin{tabular}{|l|l|l|l|}
\hline Compounds & Formula & Mass Needed & Actual Wt, grams \\
\hline Manganous Nitrate Solution & $50 \mathrm{Wt} \%$ solution & 4.01 & \\
\hline
\end{tabular}

Mix thoroughly. Will produce fine black solids, which will remain suspended while being agitated. 
Add to the kettle the following compounds with mixing to insure complete solution:

Transition Metals and Complexing agents

\begin{tabular}{|c|c|c|c|}
\hline Compounds & Formula & Mass Needed & Actual Wt, grams \\
\hline Ferric Nitrate & $\mathrm{Fe}(\mathrm{NO} 3) 3.9 \mathrm{H} 2 \mathrm{O}$ & 319.383 & \\
\hline Nickel Nitrate & $\mathrm{Ni}(\mathrm{NO} 3) 2.6 \mathrm{H} 2 \mathrm{O}$ & 13.472 & \\
\hline Zirconyl nitrate & $\begin{array}{l}\mathrm{ZrO}(\mathrm{NO} 3) 2 . \mathrm{xH} 2 \mathrm{O} \\
\mathrm{x} \sim 6\end{array}$ & 54.950 & \\
\hline Cerium nitrate & $\mathrm{Ce}(\mathrm{NO} 3) 3.6 \mathrm{H} 2 \mathrm{O}$ & 1.352 & \\
\hline Lanthanum nitrate & $\mathrm{La}(\mathrm{NO} 3) 3.6 \mathrm{H} 2 \mathrm{O}$ & 5.563 & \\
\hline Neodymium Nitrate & $\mathrm{Nd}(\mathrm{NO} 3) 3.6 \mathrm{H} 2 \mathrm{O}$ & 3.623 & \\
\hline Barium Nitrate & $\mathrm{Ba}(\mathrm{NO} 3) 2$ & 0.623 & \\
\hline Calcium Nitrate & $\mathrm{Ca}(\mathrm{NO} 3) 2.4 \mathrm{H} 2 \mathrm{O}$ & 8.247 & \\
\hline Cadmium Nitrate & $\mathrm{Cd}(\mathrm{NO} 3) 2.4 \mathrm{H} 2 \mathrm{O}$ & 9.477 & \\
\hline Chromium Nitrate & $\mathrm{Cr}(\mathrm{NO} 3) 3.9 \mathrm{H} 2 \mathrm{O}$ & 2.668 & \\
\hline Cobalt Nitrate & $\mathrm{Co}(\mathrm{NO} 3) 2.6 \mathrm{H} 2 \mathrm{O}$ & 2.187 & \\
\hline Copper Nitrate & $\mathrm{Cu}(\mathrm{NO} 3) 2.3 \mathrm{H} 2 \mathrm{O}$ & 0.576 & \\
\hline Dysprosium Nitrate & Dy(NO3)3.5H2O & 0.064 & \\
\hline Magnesium Nitrate & $\mathrm{Mg}(\mathrm{NO} 3) 2.6 \mathrm{H} 2 \mathrm{O}$ & 2.631 & \\
\hline Lead Nitrate & $\mathrm{Pb}(\mathrm{NO} 3) 2$ & 0.807 & \\
\hline Rhodium Nitrate & $\begin{array}{ll}\mathrm{Rh}(\mathrm{NO} 3) 3 & \text { Soln, } \\
4.933 \mathrm{wt} \% \mathrm{Rh} & \end{array}$ & 3.120 & \\
\hline
\end{tabular}




\begin{tabular}{|l|l|r|l|}
\hline Ruthenium Trichloride & $\mathrm{RuCl} 341.74 \mathrm{wt} \% \mathrm{Ru}$ & 0.616 & \\
\hline Strontium Nitrate & $\mathrm{Sr}(\mathrm{NO} 3) 2$ & 0.564 & \\
\hline Zinc Nitrate & $\mathrm{Zn}(\mathrm{NO} 3) 2.6 \mathrm{H} 2 \mathrm{O}$ & 0.610 & \\
\hline Silver Nitrate & $\mathrm{AgNO} 3$ & 0.545 & \\
\hline
\end{tabular}

Mix thoroughly to completely dissolve everything except the fine black solids of $\mathrm{MnO}$.

Standardize a pH electrode with $\mathrm{pH} 4,7$ and 10 buffers.

Place the $\mathrm{pH}$ electrode in the precipitation vessel with the metal nitrates and measure the $\mathrm{pH}$.

\begin{tabular}{|l|l|}
\hline $\mathrm{pH}$ & \\
\hline
\end{tabular}

With the nitrate solution agitating, slowly add 8 molar $\mathrm{NaOH}$,

$200 \quad$ grams of $\mathrm{NaOH}$ plus $\quad 600 \quad$ grams of Water (Info only)

, until the $\mathrm{pH}$ reaches 10 .

$\mathrm{pH}$

Continue mixing for 1 Hour and then recheck $\mathrm{pH}$.

\begin{tabular}{|l|l|}
\hline $\mathrm{pH}$ & \\
\hline
\end{tabular}


Next add

Thoroughly mix the slurry to insure good mixing.

\begin{tabular}{|l|l|}
\hline $\mathrm{pH}$ & \\
\hline
\end{tabular}

Allow the slurry to settle overnight or over a weekend.

Decant the supernate .

Wash the settled solids with a $0.01 \mathrm{M} \mathrm{NaOH}$ and $0.01 \mathrm{M} \mathrm{NaNO2} \mathrm{Solution}$ until the supernate is less than $1000 \mathrm{mg} / \mathrm{L}$ Nitrate.

Washing can be accomplished by multiple dilutions with gravity settling or by continuous crossflow filtration.

Concentrate the washed solids until the final volume desired is obtained.

\begin{tabular}{|l|r|l|}
\cline { 2 - 3 } \multicolumn{1}{c|}{} & Goal, $\mathrm{mL}$ & Actual, $\mathrm{mL}$ \\
\hline Final Volume & 1000 & \\
\hline
\end{tabular}

Final Insoluble Compounds Addition 


\begin{tabular}{|l|l|r|l|l|}
\hline Compounds & Formula & Mass Needed & Actual Wt, grams & $\begin{array}{l}\text { Required Particle } \\
\text { Size }\end{array}$ \\
\hline Titanium dioxide & TiO2 & 0.071 & & $<5$ microns \\
\hline Silica & $\mathrm{SiO} 2$ & 4.67 & & $<5$ microns \\
\hline Aluminum Oxide & $\mathrm{Al} 2 \mathrm{O} 3$ & 16.95 & & $<5$ microns \\
\hline
\end{tabular}

Mix thoroughly for 30 minutes.

Final Soluble Compound Addition

Salts

\begin{tabular}{|l|l|r|l|}
\hline Compounds & Formula & Mass Needed & Actual Wt, grams \\
\hline Sodium Perrhenate & $\mathrm{NaReO} 4$ & 0.036 & \\
\hline Potassium Nitrate & $\mathrm{KNO} 3$ & 2.503 & \\
\hline Potassium Molybdate & $\mathrm{K} 2 \mathrm{MoO} 4$ & 0.056 & \\
\hline Boric Acid & $\mathrm{H} 3 \mathrm{BO} 3$ & 0.712 & \\
\hline Sodium Chloride & $\mathrm{NaCl}$ & 0.065 & \\
\hline Sodium Fluoride & $\mathrm{NaF}$ & 0.476 & \\
\hline Sodium Sulfate & $\mathrm{Na} 2 \mathrm{SO} 4$ & 2.079 & \\
\hline Sodium Phosphate & $\mathrm{Na3PO} 4.12 \mathrm{H} 2 \mathrm{O}$ & 19.864 & \\
\hline Sodium Nitrate & $\mathrm{NaNO} 3$ & 3.988 & \\
\hline Sodium Nitrite & $\mathrm{NaNO} 2$ & 8.350 & \\
\hline
\end{tabular}


Mix the slurry for an hour to completely dissolve the added salts. 


\section{Appendix E Envelope A Entrained Solids Simulant Spreadsheet}

\section{Table 55 AN-105 Entrained Solids}

\begin{tabular}{|c|c|c|c|c|c|c|c|c|c|}
\hline Component & $\begin{array}{c}\text { grams/100 grams } \\
\text { Sample } \\
\end{array}$ & Mole Wt & Moles & Compound & Moles & Mole Wt & Wt & Wt \% of sample & Wt \% simulant \\
\hline TOC & 0.065 & 12.011 & $5.41 \mathrm{E}-03$ & Oxalate & $2.71 \mathrm{E}-03$ & 88.024 & 0.238 & 41.79 & \\
\hline $\mathrm{Al}$ & 0.025 & 26.98 & $9.27 \mathrm{E}-04$ & $\mathrm{Al} 2 \mathrm{O} 3$ & $4.63 \mathrm{E}-04$ & 101.96 & 0.047 & 8.29 & 9.2 \\
\hline $\mathrm{Ca}$ & 0.008 & 40.08 & $2.00 \mathrm{E}-04$ & CaOxalate & $2.00 \mathrm{E}-04$ & 128.1 & 0.026 & 4.49 & 5.0 \\
\hline $\mathrm{Cr}$ & 0.103 & 58.93 & $1.75 \mathrm{E}-03$ & $\mathrm{Cr} 2 \mathrm{O} 3$ & $8.74 \mathrm{E}-04$ & 152.02 & 0.133 & 23.31 & 26.0 \\
\hline $\mathrm{Fe}$ & 0.004 & 55.85 & $7.16 \mathrm{E}-05$ & $\mathrm{Fe} 2 \mathrm{O} 3$ & $3.58 \mathrm{E}-05$ & 159.7 & 0.006 & 1.00 & 1.1 \\
\hline $\mathrm{Mn}$ & 0.001 & 54.94 & $1.82 \mathrm{E}-05$ & $\mathrm{MnO} 2$ & $1.82 \mathrm{E}-05$ & 86.94 & 0.002 & 0.28 & 0.3 \\
\hline $\mathrm{Na}$ & 0.092 & 22.99 & $4.00 \mathrm{E}-03$ & NaOxalate & $2.00 \mathrm{E}-03$ & 134 & 0.268 & 47.04 & 52.4 \\
\hline $\mathrm{Ni}$ & 0.002 & 58.69 & $3.41 \mathrm{E}-05$ & $\mathrm{NiO}$ & $3.41 \mathrm{E}-05$ & 74.71 & 0.003 & 0.45 & 0.5 \\
\hline $\mathrm{Si}$ & 0.013 & 28.09 & 4.63E-04 & $\mathrm{SiO} 2$ & 4.63E-04 & 60.09 & 0.028 & 4.88 & 5.4 \\
\hline Solids & 0.57 & & & & & Total & 0.511 & 89.7 & 100.0 \\
\hline & & & & & & $\%$ of Solids & 89.7 & & \\
\hline & & & & \multicolumn{2}{|c|}{ \%Oxalate used } & & & & \\
\hline & & & & 81.32 & & & & & \\
\hline
\end{tabular}

\begin{tabular}{|c|c|}
\hline Recipe & grams/100 grams of \\
\hline $\mathrm{Al} 2 \mathrm{O} 3$ & 9.2 \\
\hline $\mathrm{CaOxalate}$ & 5.0 \\
\hline $\mathrm{Cr} 2 \mathrm{O} 3$ & 26.0 \\
\hline $\mathrm{Fe} 2 \mathrm{O} 3$ & 1.1 \\
\hline $\mathrm{MnO} 2$ & 0.3 \\
\hline $\mathrm{NaOxalate}$ & 52.4 \\
\hline $\mathrm{NiO}$ & 0.5 \\
\hline $\mathrm{SiO} 2$ & 5.4 \\
\hline
\end{tabular}




\section{Appendix F Envelope C Entrained Solids Simulant Spreadsheet}

\section{Table 56 First Wash of AN-107 Solids}

\begin{tabular}{|c|c|c|c|c|c|c|c|c|c|c|}
\hline \multirow{3}{*}{\begin{tabular}{|l} 
First Wash \\
Component \\
\end{tabular}} & \multirow[b]{3}{*}{$\mathrm{mg} /$ Liter } & \multirow[b]{3}{*}{ MW } & \multirow[b]{3}{*}{ Molar } & \multirow{3}{*}{\begin{tabular}{|c|} 
Initial AN-107 \\
mg/Liter \\
\end{tabular}} & \multirow{3}{*}{$\begin{array}{c}\text { Initial AN-107 } \\
\text { Molar } \\
\end{array}$} & \multirow{3}{*}{$\begin{array}{c}\text { Dilution } \\
\text { Factor }\end{array}$} & \multirow{3}{*}{ Status } & \multicolumn{3}{|c|}{ Assume Dilution Factor is 8.8} \\
\hline & & & & & & & & \multicolumn{2}{|c|}{ Diluted Conc. } & \multirow{2}{*}{\begin{tabular}{|l}
$\begin{array}{l}\text { Due to } \\
\text { Dissolution }\end{array}$ \\
mg/Liter \\
\end{tabular}} \\
\hline & & & & & & & & Molar & mg/Liter & \\
\hline Aluminum & 1140 & 26.98154 & 4.23E-02 & 386 & $1.43 \mathrm{E}-02$ & 0.3 & Dissolving & $1.63 \mathrm{E}-03$ & 43.9 & 1096.1 \\
\hline Calcium & 70 & 40.08 & $1.75 \mathrm{E}-03$ & 591 & $1.47 \mathrm{E}-02$ & 8.4 & dilution & $1.68 \mathrm{E}-03$ & 67.2 & $\mathrm{XXXXX}$ \\
\hline Cadmium & 7.3 & 112.41 & $6.49 \mathrm{E}-05$ & 64 & 5.69E-04 & 8.8 & dilution & $6.47 \mathrm{E}-05$ & 7.3 & XXXXX \\
\hline Chromium & 59.8 & 51.996 & $1.15 \mathrm{E}-03$ & 176 & $3.38 \mathrm{E}-03$ & 2.9 & Dissolving & $3.85 \mathrm{E}-04$ & 20.0 & 39.8 \\
\hline Copper & 3.8 & 58.9332 & $6.45 \mathrm{E}-05$ & 30 & 5.09E-04 & 7.9 & dilution & $5.78 \mathrm{E}-05$ & 3.4 & XXXXX \\
\hline Iron & 3.1 & 55.847 & $5.55 \mathrm{E}-05$ & 1690 & $3.03 \mathrm{E}-02$ & 545.2 & Sol. Limited & $3.44 \mathrm{E}-03$ & 192.0 & XXXXX \\
\hline Potassium & 183 & 39.0983 & $4.68 \mathrm{E}-03$ & 1810 & $4.63 \mathrm{E}-02$ & 9.9 & Dilution & $5.26 \mathrm{E}-03$ & 205.7 & XXXXX \\
\hline Manganese & 1 & 54.938 & $1.82 \mathrm{E}-05$ & 563 & $1.02 \mathrm{E}-02$ & 563.0 & Sol. Limited & $1.16 \mathrm{E}-03$ & 64.0 & XXXXX \\
\hline Sodium & 32900 & 22.98977 & $1.43 \mathrm{E}+00$ & 195000 & $8.48 \mathrm{E}+00$ & 5.9 & Dissolving & $9.64 \mathrm{E}-01$ & 22159.1 & 10740.9 \\
\hline
\end{tabular}


WESTINGHOUSE SAVANNAH RIVER COMPANY

Hanford Waste Simulants Created to Support Research and

Development on the River Protection Project - Waste Treatment Plant
Report: $\quad$ WSRC-TR-2000-00338 SRT-RPP-2000-00017

Revision (Date): $\quad 0(02 / 22 / 2001)$

\begin{tabular}{|c|c|c|c|c|c|c|c|c|c|c|}
\hline \multirow{3}{*}{$\begin{array}{l}\text { First Wash } \\
\text { Nickel } \\
\end{array}$} & \multirow[b]{3}{*}{58.6} & \multirow[b]{3}{*}{58.69} & \multirow{3}{*}{ 9.98E-04 } & \multirow{3}{*}{\begin{tabular}{|c|} 
Initial AN-107 \\
530 \\
\end{tabular}} & \multirow{3}{*}{$\begin{array}{c}\text { Initial AN-107 } \\
9.03 \mathrm{E}-03 \\
\end{array}$} & \multirow{3}{*}{$\begin{array}{c}\text { Dilution } \\
\text { Factor } \\
9.0 \\
\end{array}$} & \multirow{3}{*}{\begin{tabular}{|l} 
Status \\
Dilution \\
\end{tabular}} & \multicolumn{3}{|c|}{ Assume Dilution Factor is 8.8} \\
\hline & & & & & & & & \multicolumn{2}{|c|}{ Diluted Conc. } & \multirow{2}{*}{\begin{tabular}{|l}
$\begin{array}{l}\text { Due to } \\
\text { Dissolution }\end{array}$ \\
XXXXX
\end{tabular}} \\
\hline & & & & & & & & $1.03 \mathrm{E}-03$ & 60.2 & \\
\hline Phosphorus & 73.9 & 30.97376 & $2.39 \mathrm{E}-03$ & & & & & & & XXXXX \\
\hline Lead & 46 & 207.2 & $2.22 \mathrm{E}-04$ & 388 & $1.87 \mathrm{E}-03$ & 8.4 & Dilution & $2.13 \mathrm{E}-04$ & 44.1 & XXXXX \\
\hline Silicon & 17.3 & 28.0855 & $6.16 \mathrm{E}-04$ & & & & & & & 17.3 \\
\hline Zinc & 2.4 & 65.38 & $3.67 \mathrm{E}-05$ & 45 & $6.88 \mathrm{E}-04$ & 18.8 & SolLimited & $7.82 \mathrm{E}-05$ & 5.1 & XXXXX \\
\hline TOC & 7550 & 12.011 & $6.29 \mathrm{E}-01$ & 40400 & $3.36 \mathrm{E}+00$ & 5.4 & Dissolving & $3.82 \mathrm{E}-01$ & 4590.9 & 2959.1 \\
\hline TIC & 3070 & 12.011 & $2.56 \mathrm{E}-01$ & 16800 & $1.40 \mathrm{E}+00$ & 5.5 & Dissolving & $1.59 \mathrm{E}-01$ & 1909.1 & 1160.9 \\
\hline Chloride & 230 & 35.453 & $6.49 \mathrm{E}-03$ & 1830 & $5.16 \mathrm{E}-02$ & 8.0 & Dilution & $5.87 \mathrm{E}-03$ & 208.0 & XXXXX \\
\hline Fluoride & 1050 & 18.998 & $5.53 \mathrm{E}-02$ & 133 & $7.00 \mathrm{E}-03$ & 0.1 & Dissolving & $7.96 \mathrm{E}-04$ & 15.1 & 1034.9 \\
\hline Nitrate & 26150 & 62.0049 & $4.22 \mathrm{E}-01$ & 230000 & $3.71 \mathrm{E}+00$ & 8.8 & Dilution & $4.22 \mathrm{E}-01$ & 26136.4 & XXXXX \\
\hline Sulfate & 1530 & 96.0576 & $1.59 \mathrm{E}-02$ & 8250 & 8.59E-02 & 5.4 & Dissolving & $9.76 \mathrm{E}-03$ & 937.5 & 592.5 \\
\hline Phosphate & 1240 & 94.97136 & $1.31 \mathrm{E}-02$ & 1110 & $1.17 \mathrm{E}-02$ & 0.9 & Dissolving & $1.33 \mathrm{E}-03$ & 126.1 & 1113.9 \\
\hline
\end{tabular}




\section{Table 57 Second Wash of Solids from Tank AN-107}

\begin{tabular}{|c|c|c|c|c|c|c|c|c|c|c|}
\hline \multirow[b]{2}{*}{ Second Wash } & & & & & & & & \multicolumn{2}{|c|}{ Assume Dilution Factor is } & \multirow[b]{2}{*}{\begin{tabular}{|l} 
Due to \\
Dissolution
\end{tabular}} \\
\hline & & & & First Wash & $\begin{array}{c}\text { First } \\
\text { Wash }\end{array}$ & $\begin{array}{l}\text { Dilution } \\
\text { Factor }\end{array}$ & Status & $\begin{array}{l}\text { Diluted } \\
\text { Conc. } \\
\end{array}$ & & \\
\hline Component & mg/Liter & MW & Molar & mg/Liter & Molar & & & Molar & mg/Liter & mg/Liter \\
\hline Aluminum & 83.4 & 26.98154 & $3.09 \mathrm{E}-03$ & 1140 & 4.23E-02 & 13.7 & Dissolving & $1.69 \mathrm{E}-03$ & 45.6 & 37.8 \\
\hline Calcium & 1.3 & 40.08 & $3.24 \mathrm{E}-05$ & 70 & $1.75 \mathrm{E}-03$ & 53.8 & Sol. Limited & $6.99 \mathrm{E}-05$ & 2.8 & XXXXX \\
\hline Cadmium & 0.3 & 112.41 & $2.67 \mathrm{E}-06$ & 7.3 & $6.49 \mathrm{E}-05$ & 24.3 & Dilution & $2.60 \mathrm{E}-06$ & 0.3 & XXXXX \\
\hline Chromium & 17.1 & 51.996 & $3.29 \mathrm{E}-04$ & 59.8 & $1.15 \mathrm{E}-03$ & 3.5 & Dissolving & $4.60 \mathrm{E}-05$ & 2.4 & 14.7 \\
\hline Copper & 0.3 & 58.9332 & $5.09 \mathrm{E}-06$ & 3.8 & $6.45 \mathrm{E}-05$ & 12.7 & Dissolving & $2.58 \mathrm{E}-06$ & 0.2 & 0.1 \\
\hline Iron & 0.6 & 55.847 & $1.07 \mathrm{E}-05$ & 3.1 & $5.55 \mathrm{E}-05$ & 5.2 & Dissolving & $2.22 \mathrm{E}-06$ & 0.1 & 0.5 \\
\hline Potassium & & 39.0983 & $0.00 \mathrm{E}+00$ & 183 & $4.68 \mathrm{E}-03$ & XXXXXX & & XXXXXX & XXXXXX & XXXXX \\
\hline Manganese & 0.15 & 54.938 & $2.73 \mathrm{E}-06$ & 1 & $1.82 \mathrm{E}-05$ & 6.7 & Dissolving & $7.28 \mathrm{E}-07$ & 0.0 & XXXXX \\
\hline Sodium & 1500 & 22.98977 & $6.52 \mathrm{E}-02$ & 32900 & $1.43 \mathrm{E}+00$ & 21.9 & Dilution & $5.72 \mathrm{E}-02$ & 1316.0 & XXXXX \\
\hline Nickel & 2.1 & 58.69 & $3.58 \mathrm{E}-05$ & 58.6 & $9.98 \mathrm{E}-04$ & 27.9 & Dilution & 3.99E-05 & 2.3 & XXXXX \\
\hline
\end{tabular}




\section{WESTINGHOUSE SAVANNAH RIVER COMPANY}

Hanford Waste Simulants Created to Support Research and

Development on the River Protection Project - Waste Treatment Plant
Report: $\quad$ WSRC-TR-2000-00338 SRT-RPP-2000-00017

Revision (Date): $\quad 0(02 / 22 / 2001)$

\begin{tabular}{|c|c|c|c|c|c|c|c|c|c|c|}
\hline \multirow[b]{2}{*}{ Second Wash } & & & & & & & & \multicolumn{2}{|c|}{ Assume Dilution Factor is } & \multirow{2}{*}{$\begin{array}{l}\text { Due } \\
\text { Dissolution }\end{array}$} \\
\hline & & & & First Wash & $\begin{array}{c}\text { First } \\
\text { Wash }\end{array}$ & $\begin{array}{l}\text { Dilution } \\
\text { Factor }\end{array}$ & Status & $\begin{array}{l}\text { Diluted } \\
\text { Conc. }\end{array}$ & & \\
\hline Phosphorus & 3 & 30.97376 & $9.69 \mathrm{E}-05$ & 73.9 & $2.39 \mathrm{E}-03$ & 24.6 & Dilution & $9.54 \mathrm{E}-05$ & 3.0 & XXXXX \\
\hline Lead & 1.9 & 207.2 & 9.17E-06 & 46 & $2.22 \mathrm{E}-04$ & 24.2 & Dilution & $8.88 \mathrm{E}-06$ & 1.8 & XXXXX \\
\hline Silicon & 24.9 & 28.0855 & 8.87E-04 & 17.3 & $6.16 \mathrm{E}-04$ & 0.7 & Dissolving & $2.46 \mathrm{E}-05$ & 0.7 & 24.2 \\
\hline Zinc & 0.3 & 65.38 & $4.59 \mathrm{E}-06$ & 2.4 & $3.67 \mathrm{E}-05$ & 8.0 & Dissolving & $1.47 \mathrm{E}-06$ & 0.1 & 0.2 \\
\hline TOC & 244 & 12.011 & $2.03 \mathrm{E}-02$ & 7550 & $6.29 \mathrm{E}-01$ & 30.9 & Dilution & $2.51 \mathrm{E}-02$ & 302.0 & XXXXX \\
\hline TIC & 286 & 12.011 & $2.38 \mathrm{E}-02$ & 3070 & $2.56 \mathrm{E}-01$ & 10.7 & Dissolving & $1.02 \mathrm{E}-02$ & 122.8 & 163.2 \\
\hline Chloride & 12 & 35.453 & $3.38 \mathrm{E}-04$ & 230 & 6.49E-03 & 19.2 & Dissolving & $2.59 \mathrm{E}-04$ & 9.2 & 2.8 \\
\hline Fluoride & 75 & 18.998 & $3.95 \mathrm{E}-03$ & 1050 & $5.53 \mathrm{E}-02$ & 14.0 & Dissolving & $2.21 \mathrm{E}-03$ & 42.0 & 33.0 \\
\hline Nitrate & 960 & 62.0049 & $1.55 \mathrm{E}-02$ & 26150 & $4.22 \mathrm{E}-01$ & 27.2 & Dilution & $1.69 \mathrm{E}-02$ & 1046.0 & XXXXX \\
\hline Sulfate & 65 & 96.0576 & 6.77E-04 & 1530 & $1.59 \mathrm{E}-02$ & 23.5 & Dilution & $6.37 \mathrm{E}-04$ & 61.2 & XXXXX \\
\hline Phosphate & 55 & 94.97136 & $5.79 \mathrm{E}-04$ & 1240 & $1.31 \mathrm{E}-02$ & 22.5 & Dilution & $5.22 \mathrm{E}-04$ & 49.6 & XXXXX \\
\hline
\end{tabular}


Table 58 Third Wash of Solids From tank AN-107

\begin{tabular}{|c|c|c|c|c|c|c|c|c|c|c|}
\hline & & & & & & & & $\begin{array}{l}\text { Assume Dilu } \\
\text { is }\end{array}$ & ution Facto & 16 \\
\hline \multicolumn{2}{|c|}{ Third Wash } & \multirow[b]{2}{*}{ MW } & \multirow[b]{2}{*}{ Molar } & \multirow{2}{*}{$\begin{array}{c}\text { Second } \\
\text { Wash } \\
\text { mg/Liter }\end{array}$} & \multirow{2}{*}{$\begin{array}{c}\text { First Wash } \\
\text { Molar } \\
\end{array}$} & \multirow[t]{2}{*}{ Dilution Factor } & \multirow[t]{2}{*}{ Status } & \multicolumn{2}{|l|}{ Diluted Conc. } & \multirow{2}{*}{\begin{tabular}{|l} 
Due \\
Dissolution
\end{tabular}} \\
\hline Component & $\mathrm{mg} /$ Liter & & & & & & & Molar & mg/Liter & \\
\hline Aluminum & 44.6 & 26.98154 & $1.65 \mathrm{E}-03$ & 83.4 & $3.09 \mathrm{E}-03$ & 1.9 & Dissolving & $1.93 \mathrm{E}-04$ & 5.2 & 39.4 \\
\hline Calcium & & 40.08 & XXXXX & 1.3 & $3.24 \mathrm{E}-05$ & XXXXX & $<\mathrm{DL}$ & $2.03 \mathrm{E}-06$ & 0.1 & XXXXX \\
\hline Cadmium & & 112.41 & XXXXX & 0.3 & $2.67 \mathrm{E}-06$ & XXXXX & $<\mathrm{DL}$ & $1.67 \mathrm{E}-07$ & 0.0 & XXXXX \\
\hline Chromium & 10.2 & 51.996 & $1.96 \mathrm{E}-04$ & 17.1 & $3.29 \mathrm{E}-04$ & 1.7 & Dissolving & $2.06 \mathrm{E}-05$ & 1.1 & 9.1 \\
\hline Copper & 0.1 & 58.9332 & $1.70 \mathrm{E}-06$ & 0.3 & $5.09 \mathrm{E}-06$ & 3.0 & Dissolving & $3.18 \mathrm{E}-07$ & 0.0 & 0.1 \\
\hline Iron & 4.9 & 55.847 & $8.77 \mathrm{E}-05$ & 0.6 & $1.07 \mathrm{E}-05$ & 0.1 & Dissolving & $6.71 \mathrm{E}-07$ & 0.0 & 4.9 \\
\hline Potassium & & 39.0983 & XXXXX & 0 & $0.00 \mathrm{E}+00$ & XXXXX & $<\mathrm{DL}$ & $\mathrm{XXXXX}$ & XXXXX & XXXXX \\
\hline Manganese & 0.8 & 54.938 & $1.46 \mathrm{E}-05$ & 0.15 & $2.73 \mathrm{E}-06$ & 0.2 & Dissolving & $1.71 \mathrm{E}-07$ & 0.0 & XXXXX \\
\hline Sodium & 354 & 22.98977 & $1.54 \mathrm{E}-02$ & 1500 & $6.52 \mathrm{E}-02$ & 4.2 & Dilution & $4.08 \mathrm{E}-03$ & 93.8 & $\mathrm{XXXXX}$ \\
\hline Nickel & 0.2 & 58.69 & $3.41 \mathrm{E}-06$ & 2.1 & $3.58 \mathrm{E}-05$ & 10.5 & Dil+Wash & $2.24 \mathrm{E}-06$ & 0.1 & $\mathrm{XXXXX}$ \\
\hline
\end{tabular}




\section{WESTINGHOUSE SAVANNAH RIVER COMPANY}

Hanford Waste Simulants Created to Support Research and

Development on the River Protection Project - Waste Treatment Plant
Report: $\quad$ WSRC-TR-2000-00338

SRT-RPP-2000-00017

Revision (Date): $\quad 0(02 / 22 / 2001)$

\begin{tabular}{|c|c|c|c|c|c|c|c|c|c|c|}
\hline & & & & & & & & \multicolumn{3}{|c|}{$\begin{array}{l}\text { Assume Dilution Factor } \\
\text { is }\end{array}$} \\
\hline \multicolumn{2}{|c|}{ Third Wash } & \multirow[b]{2}{*}{ MW } & \multirow[b]{2}{*}{ Molar } & \multirow{2}{*}{$\begin{array}{c}\text { Second } \\
\text { Wash } \\
\text { mg/Liter }\end{array}$} & \multirow{2}{*}{$\begin{array}{c}\text { First Wash } \\
\text { Molar } \\
\end{array}$} & \multirow{2}{*}{\begin{tabular}{|l|} 
Dilution Factor \\
\end{tabular}} & \multirow[t]{2}{*}{ Status } & \multicolumn{2}{|l|}{ Diluted Conc. } & \multirow{2}{*}{\begin{tabular}{|l}
$\begin{array}{l}\text { Due } \\
\text { Dissolution }\end{array}$ \\
mg/Liter \\
\end{tabular}} \\
\hline Component & $\mathrm{mg} /$ Liter & & & & & & & Molar & mg/Liter & \\
\hline Phosphorus & 2.8 & 30.97376 & $9.04 \mathrm{E}-05$ & 3 & $9.69 \mathrm{E}-05$ & 1.1 & Dilution & $6.05 \mathrm{E}-06$ & 0.2 & $\mathrm{XXXXX}$ \\
\hline Lead & & 207.2 & $\mathrm{XXXXX}$ & 1.9 & $9.17 \mathrm{E}-06$ & $\mathrm{XXXXX}$ & $<\mathrm{DL}$ & 5.73E-07 & 0.1 & XXXXX \\
\hline Silicon & 23.9 & 28.0855 & 8.51E-04 & 24.9 & 8.87E-04 & 1.0 & Dissolving & $5.54 \mathrm{E}-05$ & 1.6 & 22.3 \\
\hline Zinc & & 65.38 & $\mathrm{XXXXX}$ & 0.3 & $4.59 \mathrm{E}-06$ & $\mathrm{XXXXX}$ & $<\mathrm{DL}$ & $2.87 \mathrm{E}-07$ & 0.0 & $\mathrm{XXXXX}$ \\
\hline TOC & & 12.011 & $\mathrm{XXXXX}$ & 244 & $2.03 \mathrm{E}-02$ & $\mathrm{XXXXX}$ & $<\mathrm{DL}$ & $1.27 \mathrm{E}-03$ & 15.3 & XXXXX \\
\hline TIC & 127 & 12.011 & $1.06 \mathrm{E}-02$ & 286 & $2.38 \mathrm{E}-02$ & 2.3 & Dissolving & $1.49 \mathrm{E}-03$ & 17.9 & 109.1 \\
\hline Chloride & 2 & 35.453 & $5.64 \mathrm{E}-05$ & 12 & $3.38 \mathrm{E}-04$ & 6.0 & Dilution & $2.12 \mathrm{E}-05$ & 0.8 & 1.3 \\
\hline Fluoride & 23 & 18.998 & $1.21 \mathrm{E}-03$ & 75 & $3.95 \mathrm{E}-03$ & 3.3 & Dissolving & $2.47 \mathrm{E}-04$ & 4.7 & 18.3 \\
\hline Nitrate & 58 & 62.0049 & 9.35E-04 & 960 & $1.55 \mathrm{E}-02$ & 16.6 & Dilution & $9.68 \mathrm{E}-04$ & 60.0 & $\mathrm{XXXXX}$ \\
\hline Sulfate & 5 & 96.0576 & $5.21 \mathrm{E}-05$ & 65 & $6.77 \mathrm{E}-04$ & 13.0 & Dilution & $4.23 \mathrm{E}-05$ & 4.1 & $\mathrm{XXXXX}$ \\
\hline Phosphate & 3 & 94.97136 & $3.16 \mathrm{E}-05$ & 55 & $5.79 \mathrm{E}-04$ & 18.3 & Dilution & $3.62 \mathrm{E}-05$ & 3.4 & XXXXX \\
\hline
\end{tabular}

\begin{tabular}{|l|r|r|}
\hline Sodium Wash & 22.98977 \\
\hline
\end{tabular}$\quad$\begin{tabular}{ll|}
\hline 230 & 0.01 \\
\hline
\end{tabular}




\section{WESTINGHOUSE SAVANNAH RIVER COMPANY}

Hanford Waste Simulants Created to Support Research and Development on the River Protection Project - Waste Treatment Plant
Report: $\quad$ WSRC-TR-2000-00338

SRT-RPP-2000-00017

Revision (Date): $\quad 0(02 / 22 / 2001)$

Page: $\quad 142$ of 142 
Table 59 Fourth Wash of Solids from Tank AN-107

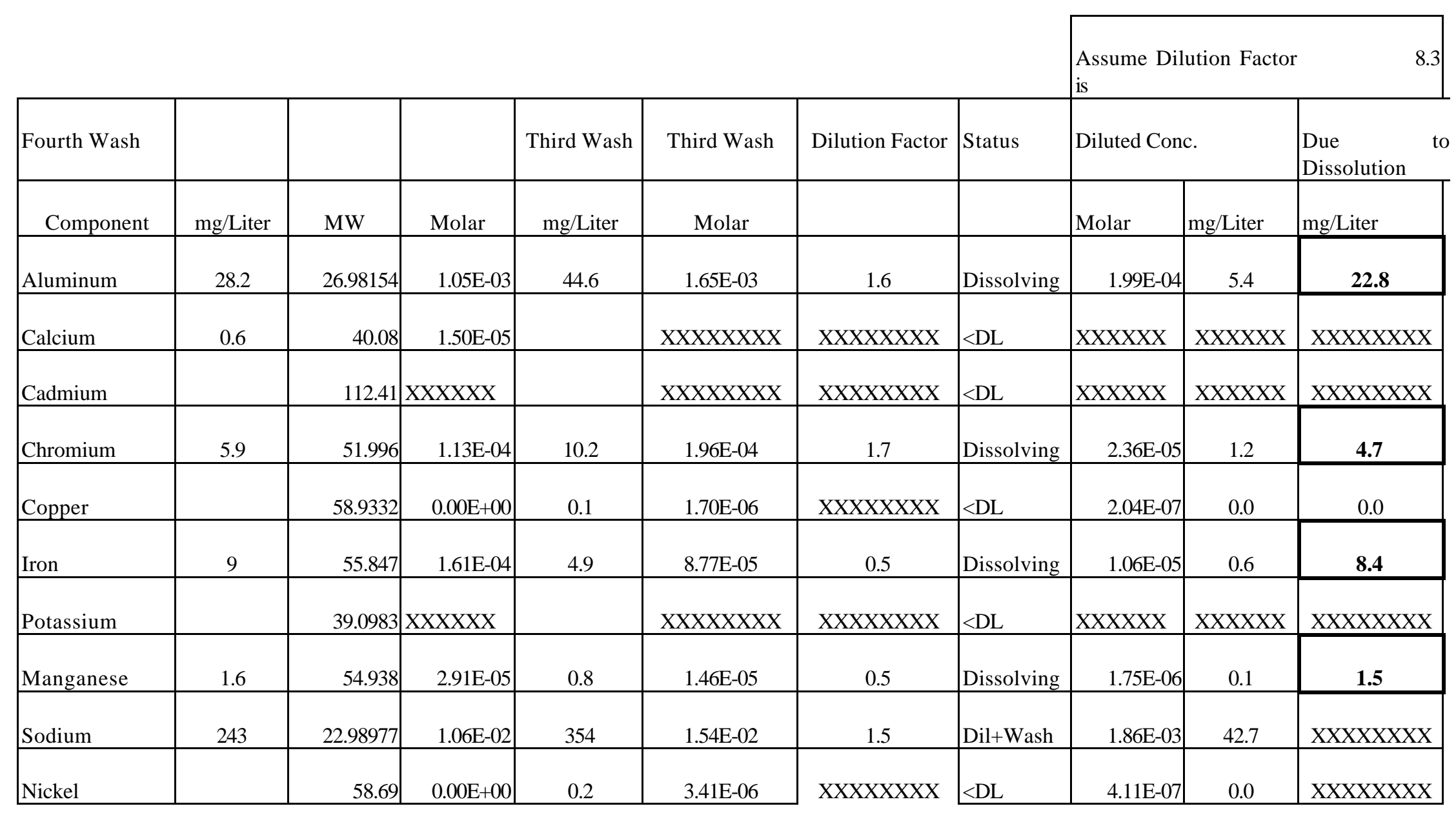




\section{WESTINGHOUSE SAVANNAH RIVER COMPANY}

Hanford Waste Simulants Created to Support Research and

Development on the River Protection Project - Waste Treatment Plant
Report: $\quad$ WSRC-TR-2000-00338

SRT-RPP-2000-00017

Revision (Date): $\quad 0(02 / 22 / 2001)$

Page: $\quad 144$ of 142

\begin{tabular}{|c|c|c|c|c|c|c|c|c|c|c|}
\hline & & & & & & & & \multicolumn{3}{|c|}{$\begin{array}{l}\text { Assume Dilution Factor } \\
\text { is }\end{array}$} \\
\hline Fourth Wash & & & & Third Wash & Third Wash & Dilution Factor & Status & Diluted Conc & & \begin{tabular}{|l} 
Due \\
Dissolution \\
\end{tabular} \\
\hline Component & mg/Liter & MW & Molar & $\mathrm{mg} /$ Liter & Molar & & & Molar & mg/Liter & mg/Liter \\
\hline Phosphorus & 1.7 & 30.97376 & $5.49 \mathrm{E}-05$ & 2.8 & 9.04E-05 & 1.6 & Dilution & $1.09 \mathrm{E}-05$ & 0.3 & 1.4 \\
\hline Lead & 0.4 & 207.2 & $1.93 \mathrm{E}-06$ & & XXXXXXXX & XXXXXXXX & $<\mathrm{DL}$ & $\mathrm{XXXXXX}$ & $\mathrm{XXXXXX}$ & XXXXXXXX \\
\hline Silicon & 16.6 & 28.0855 & 5.91E-04 & 23.9 & 8.51E-04 & 1.4 & Dissolving & $1.03 \mathrm{E}-04$ & 2.9 & 13.7 \\
\hline Zinc & 0.1 & 65.38 & $1.53 \mathrm{E}-06$ & & XXXXXXXX & XXXXXXXX & $<\mathrm{DL}$ & $\mathrm{XXXXXX}$ & XXXXXX & XXXXXXXX \\
\hline TOC & & 12.011 & XXXXXX & & XXXXXXXX & XXXXXXXX & $<\mathrm{DL}$ & XXXXXX & $\mathrm{XXXXXX}$ & XXXXXXXX \\
\hline TIC & 110 & 12.011 & $9.16 \mathrm{E}-03$ & 127 & $1.06 \mathrm{E}-02$ & 1.2 & Dissolving & $1.27 \mathrm{E}-03$ & 15.3 & 94.7 \\
\hline Chloride & 3 & 35.453 & $8.46 \mathrm{E}-05$ & 2 & $5.64 \mathrm{E}-05$ & 0.7 & Dissolving & $6.80 \mathrm{E}-06$ & 0.2 & 2.8 \\
\hline Fluoride & 12 & 18.998 & $6.32 \mathrm{E}-04$ & 23 & $1.21 \mathrm{E}-03$ & 1.9 & Dissolving & $1.46 \mathrm{E}-04$ & 2.8 & 9.2 \\
\hline Nitrate & 7 & 62.0049 & 1.13E-04 & 58 & 9.35E-04 & 8.3 & Dilution & $1.13 \mathrm{E}-04$ & 7.0 & XXXXXXXX \\
\hline Sulfate & 3 & 96.0576 & $3.12 \mathrm{E}-05$ & 5 & $5.21 \mathrm{E}-05$ & 1.7 & Dissolving & $6.27 \mathrm{E}-06$ & 0.6 & 2.4 \\
\hline Phosphate & 3 & 94.97136 & $3.16 \mathrm{E}-05$ & 3 & $3.16 \mathrm{E}-05$ & 1.0 & Dissolving & $3.81 \mathrm{E}-06$ & 0.4 & 2.6 \\
\hline
\end{tabular}

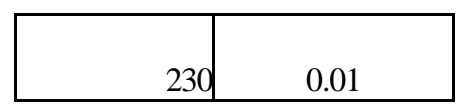


WESTINGHOUSE SAVANNAH RIVER COMPANY

Hanford Waste Simulants Created to Support Research and Development on the River Protection Project - Waste Treatment Plant
Report:

WSRC-TR-2000-00338

SRT-RPP-2000-00017

Revision (Date): $\quad 0(02 / 22 / 2001)$

Page:

Table 60 Summary of Washes for Tank AN-107 Solids

\begin{tabular}{|c|c|c|c|c|}
\hline & Wash 1 & Wash 2 & Wash 3 & Wash 4 \\
\hline Factor (Volume) & 18.837 & 17.824 & 18.054 & 18.325 \\
\hline & Dissolved & Dissolved & Dissolved & Dissolved \\
\hline Component & microgm $/ \mathrm{mL}$ & microgm $/ \mathrm{mL}$ & microgm $/ \mathrm{mL}$ & microgm $/ \mathrm{mL}$ \\
\hline Aluminum & 1096.1 & 37.8 & 39.4 & 22.8 \\
\hline Calcium & XXXXXX & XXXXXX & XXXXXX & XXXXXXX \\
\hline Cadmium & XXXXXX & XXXXXX & XXXXXX & XXXXXXX \\
\hline Chromium & 39.8 & 14.7 & 9.1 & 4.7 \\
\hline Copper & XXXXXX & 0.1 & 0.1 & 0.0 \\
\hline Iron & XXXXXX & 0.5 & 4.9 & 8.4 \\
\hline Potassium & XXXXXX & XXXXXX & XXXXXX & XXXXXXX \\
\hline Manganese & XXXXXX & XXXXXX & XXXXXX & 1.5 \\
\hline Sodium & 10740.9 & XXXXXX & XXXXXX & XXXXXXX \\
\hline Nickel & XXXXXX & XXXXXX & XXXXXX & XXXXXXX \\
\hline Phosphorus & XXXXXX & XXXXXX & XXXXXX & 1.4 \\
\hline Lead & XXXXXX & XXXXXX & XXXXXX & XXXXXXX \\
\hline Silicon & 17.3 & 24.2 & 22.3 & 13.7 \\
\hline Zinc & XXXXXX & 0.2 & XXXXXX & XXXXXXX \\
\hline TOC & 2959.1 & XXXXXX & XXXXXX & XXXXXXX \\
\hline TIC & 1160.9 & 163.2 & 109.1 & 94.7 \\
\hline Chloride & XXXXXX & 2.8 & 1.3 & 2.8 \\
\hline Fluoride & 1034.9 & 33.0 & 18.3 & 9.2 \\
\hline
\end{tabular}


Hanford Waste Simulants Created to Support Research and Revision (Date): Development on the River Protection Project - Waste Treatment Plant

\begin{tabular}{|l|c|l|l|l|}
\hline & Wash 1 & Wash 2 & Wash 3 & Wash 4 \\
\hline Factor (Volume) & 18.837 & 17.824 & 18.054 & 18.325 \\
\hline & Dissolved & Dissolved & Dissolved & Dissolved \\
\hline Component & microgm/mL & microgm/mL & microgm/mL & microgm $/ \mathrm{mL}$ \\
\hline Nitrate & XXXXXX & XXXXXX & XXXXXX & XXXXXXX \\
\hline Sulfate & 592.5 & XXXXXX & XXXXXX & 2.4 \\
\hline Phosphate & 1113.9 & XXXXXX & XXXXXX & 2.6 \\
\hline
\end{tabular}




\section{WESTINGHOUSE SAVANNAH RIVER COMPANY}

Hanford Waste Simulants Created to Support Research and

Development on the River Protection Project - Waste Treatment Plant
Report: $\quad$ WSRC-TR-2000-00338

SRT-RPP-2000-00017

Revision (Date): $\quad 0(02 / 22 / 2001)$

Page: $\quad 147$ of 142

Table 61 Solids Calculation for Unwashed Entrained Solids in Tank AN-107

\begin{tabular}{|c|c|c|c|c|c|c|c|c|c|c|c|c|c|c|c|}
\hline $\begin{array}{l}\text { Total in } \\
\text { Wash }\end{array}$ & & & & & Solids & Total & & & & & & & Mass & Simulant & $\begin{array}{l}\text { After } \\
\text { Wash }\end{array}$ \\
\hline $\begin{array}{c}\text { Componen } \\
t\end{array}$ & microgm & microgm & microgm & microgm & microgm & microgm & MW & Moles & Moles + & Moles - & Form & MW & grams & wt $\%$ & \\
\hline Aluminum & 20647.9 & 673.7 & 711.1 & 418.3 & 2254 & 24705.1 & $\begin{array}{r}26.9815 \\
4 \\
\end{array}$ & $9.16 \mathrm{E}-04$ & & & $\mathrm{Al} 2 \mathrm{O} 3$ & 101.96 & 0.042654 & 4.711761 & $\begin{array}{r}32.0613 \\
2\end{array}$ \\
\hline Calcium & XXXX & XXXX & XXXX & XXXX & 256 & 256 & 40.08 & $6.39 \mathrm{E}-06$ & $1.28 \mathrm{E}-05$ & & $\mathrm{Ca} 3(\mathrm{PO} 4) 2$ & 310.1827 & 0.00066 & 0.072951 & 0.49639 \\
\hline Cadmium & $\mathrm{XXXX}$ & XXXX & XXXX & XXXX & & & 112.41 & $\begin{array}{r}0.00 \mathrm{E}+0 \\
0\end{array}$ & & & & & & & \\
\hline Chromium & 749.7 & 262.2 & 164.9 & 85.6 & 1119 & 2381.3 & 51.996 & $4.58 \mathrm{E}-05$ & & $9.16 \mathrm{E}-05$ & $\mathrm{Cr} 2 \mathrm{O} 3$ & 152.02 & 0.003481 & 0.384539 & 2.61660 \\
\hline Copper & $\mathrm{XXXX}$ & 2.6 & 1.5 & -0.2 & 11 & 14.9 & 58.9332 & $2.53 \mathrm{E}-07$ & & & & & & & \\
\hline Iron & XXXX & 8.5 & 87.8 & 154.1 & 30096 & 30346.4 & 55.847 & $5.43 \mathrm{E}-04$ & & & $\mathrm{Fe} 2 \mathrm{O} 3$ & 159.69 & 0.043387 & 4.792659 & 32.6117 \\
\hline Potassium & XXXX & $\mathrm{XXXX}$ & $\mathrm{XXXX}$ & $\mathrm{XXXX}$ & & & 39.0983 & $\begin{array}{r}0.00 \mathrm{E}+0 \\
0 \\
\end{array}$ & & & & & & & \\
\hline Manganese & $\mathrm{XXXX}$ & $\mathrm{XXXX}$ & XXXX & 27.6 & 17721 & 17748.6 & 54.938 & $3.23 \mathrm{E}-04$ & & & $\mathrm{MnO} 2$ & 86.94 & 0.028087 & 3.102641 & 21.1120 \\
\hline Sodium & $\begin{array}{c}202326 . \\
5 \\
\end{array}$ & XXXX & XXXX & $\mathrm{XXXX}$ & 3079 & $\begin{array}{c}205405 . \\
5 \\
\end{array}$ & $\begin{array}{r}22.9897 \\
7 \\
\end{array}$ & $8.93 \mathrm{E}-03$ & $8.93 \mathrm{E}-03$ & & & & & & \\
\hline Nickel & XXXX & XXXX & XXXX & XXXX & 87 & 87 & 58.69 & $1.48 \mathrm{E}-06$ & $2.96 \mathrm{E}-06$ & & & & & & \\
\hline
\end{tabular}




\section{WESTINGHOUSE SAVANNAH RIVER COMPANY}

Hanford Waste Simulants Created to Support Research and Development on the River Protection Project - Waste Treatment Plant
Report: $\quad$ WSRC-TR-2000-00338 SRT-RPP-2000-00017

\section{Revision (Date): $\quad 0(02 / 22 / 2001)$}

Page: $\quad 148$ of 142

\begin{tabular}{|c|c|c|c|c|c|c|c|c|c|c|c|c|c|c|c|}
\hline $\begin{array}{l}\text { Total in } \\
\text { Wash }\end{array}$ & & & & & Solids & Total & & & & & & & Mass & Simulant & $\begin{array}{l}\text { After } \\
\text { Wash }\end{array}$ \\
\hline $\begin{array}{c}\text { Componen } \\
\mathrm{t}\end{array}$ & microgm & microgm & microgm & microgm & microgm & microgm & MW & Moles & Moles + & Moles - & Form & MW & grams & wt $\%$ & \\
\hline Phosphorus & $\mathrm{XXXX}$ & XXXX & XXXX & 25.0 & 192 & 217.0 & $\begin{array}{r}30.9737 \\
6\end{array}$ & $7.00 \mathrm{E}-06$ & & & & & & & \\
\hline Lead & $\mathrm{XXXX}$ & XXXX & $\mathrm{XXXX}$ & XXXX & 2010 & 2010 & 207.2 & $9.70 \mathrm{E}-06$ & & & & & & & \\
\hline Silicon & 325.9 & 431.5 & 403.4 & 251.4 & 805 & 2217.2 & 28.0855 & $7.89 \mathrm{E}-05$ & & $1.58 \mathrm{E}-04$ & $\begin{array}{c}\mathrm{Na} 2 \mathrm{O} . \mathrm{Al} 2 \mathrm{O} 3 .(\mathrm{Si} \\
\mathrm{O} 2) 2.5 \mathrm{H} 2 \mathrm{O}\end{array}$ & 374.1852 & 0.01477 & 1.631542 & $\begin{array}{r}11.1018 \\
8 \\
\end{array}$ \\
\hline Zinc & XXXX & 3.6 & XXXX & XXXX & 150 & 153.6 & 65.38 & $2.35 \mathrm{E}-06$ & & & & & & & \\
\hline TOC & 55740.4 & XXXX & XXXX & XXXX & & 55740.4 & 12.011 & $4.64 \mathrm{E}-03$ & & $4.64 \mathrm{E}-03$ & $\mathrm{Na} 2 \mathrm{C} 2 \mathrm{O} 4$ & 134 & 0.310932 & 34.34689 & \\
\hline TIC & 21868.0 & 2908.9 & 1970.1 & 1735.4 & & 28482.4 & 12.011 & $2.37 \mathrm{E}-03$ & & 4.74E-03 & $\mathrm{Na} 2 \mathrm{CO} 3 . \mathrm{H} 2 \mathrm{O}$ & 124 & 0.294049 & 32.48188 & \\
\hline Chloride & XXXX & 49.9 & 22.6 & 50.6 & & 123.0 & 35.453 & $3.47 \mathrm{E}-06$ & & $3.47 \mathrm{E}-06$ & & & & & \\
\hline Fluoride & 19494.2 & 588.2 & 330.6 & 169.1 & & 20582.1 & 18.998 & $1.08 \mathrm{E}-03$ & & $1.08 \mathrm{E}-03$ & $\mathrm{NaF}$ & 41.99 & 0.045491 & & \\
\hline Nitrate & XXXX & XXXX & XXXX & XXXX & & & 62.0049 & $\begin{array}{r}0.00 \mathrm{E}+0 \\
0\end{array}$ & & & & & & & \\
\hline Sulfate & 11160.9 & XXXX & $\mathrm{XXXX}$ & 43.9 & & 11204.9 & 96.0576 & $1.17 \mathrm{E}-04$ & & $2.33 \mathrm{E}-04$ & $\mathrm{Na} 2 \mathrm{SO} 4.10 \mathrm{H} 2 \mathrm{O}$ & 322.2 & 0.037584 & 4.151662 & \\
\hline Phosphate & 20981.8 & XXXX & XXXX & 48.4 & & 21030.2 & $\begin{array}{r}94.9713 \\
6 \\
\end{array}$ & $2.21 \mathrm{E}-04$ & & $4.43 \mathrm{E}-04$ & $\mathrm{Na} 3 \mathrm{PO} 4.12 \mathrm{H} 2 \mathrm{O}$ & 380.13 & 0.084175 & 9.298324 & \\
\hline Others & & & & & & & & & & & & & & & \\
\hline Magnesium & & & & & 113 & 113 & 24.305 & $4.65 \mathrm{E}-06$ & & & & & & & \\
\hline
\end{tabular}




\section{WESTINGHOUSE SAVANNAH RIVER COMPANY}

Hanford Waste Simulants Created to Support Research and Development on the River Protection Project - Waste Treatment Plant
Report: $\quad$ WSRC-TR-2000-00338 SRT-RPP-2000-00017

Revision (Date): $\quad 0(02 / 22 / 2001)$

\begin{tabular}{|c|c|c|c|c|c|c|c|c|c|c|c|c|c|c|c|}
\hline $\begin{array}{l}\text { Total in } \\
\text { Wash }\end{array}$ & & & & & Solids & Total & & & & & & & Mass & Simulant & $\begin{array}{l}\text { After } \\
\text { Wash }\end{array}$ \\
\hline $\begin{array}{c}\text { Componen } \\
\mathrm{t}\end{array}$ & microgm & microgm & microgm & microgm & microgm & microgm & MW & Moles & Moles + & Moles - & Form & MW & grams & wt $\%$ & \\
\hline Barium & & & & & 167 & 167 & 137.33 & $1.22 \mathrm{E}-06$ & & & & & & & \\
\hline Lanthanum & & & & & 228 & 228 & $\begin{array}{r}138.905 \\
5 \\
\end{array}$ & $1.64 \mathrm{E}-06$ & & & & & & & \\
\hline \multirow[t]{3}{*}{ Zirconium } & & & & & 282 & 282 & 91.22 & $3.09 \mathrm{E}-06$ & & & & & & & \\
\hline & & & & & total & $\begin{array}{r}423495 . \\
5 \\
\end{array}$ & & Total & $8.95 \mathrm{E}-03$ & $1.14 \mathrm{E}-02$ & $\begin{array}{c}\text { With Soluble } \\
\text { Salts }\end{array}$ & Total & 0.90527 & & \\
\hline & & & & & & & & & & & $\begin{array}{c}\text { Without Soluble } \\
\text { Salts }\end{array}$ & Total & 0.133039 & & \\
\hline
\end{tabular}

Table 62 Recipe for Unwashed Entrained Solids from Tank AN-107

\begin{tabular}{|l|c|l|}
\hline & 1.8 & grams \\
\hline Wet First Wash Solids & 0.106 & grams/Liter \\
\hline
\end{tabular}

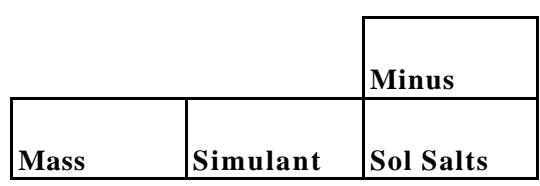


Hanford Waste Simulants Created to Support Research and Development on the River Protection Project - Waste Treatment Plant

\section{Revision (Date): $0(02 / 22 / 2001)$}

\begin{tabular}{|c|c|c|c|c|c|c|}
\hline Component & Moles & Form & Formula Wt & Grams & Wt \% & Wt \% \\
\hline Aluminum & $9.16 \mathrm{E}-04$ & $\mathrm{Al} 2 \mathrm{O} 3$ & 101.96 & 0.0467 & 5.13 & 34.06 \\
\hline Calcium & $6.39 \mathrm{E}-06$ & $\mathrm{Ca} 3(\mathrm{PO} 4) 2$ & 310.18 & 0.00066 & 0.07 & 0.48 \\
\hline Chromium & $4.58 \mathrm{E}-05$ & $\mathrm{Cr} 2 \mathrm{O} 3$ & 152.02 & 0.0035 & 0.38 & 2.54 \\
\hline Iron & $5.43 \mathrm{E}-04$ & $\mathrm{Fe} 2 \mathrm{O} 3$ & 159.69 & 0.0434 & 4.77 & 31.65 \\
\hline Manganese & $3.23 \mathrm{E}-04$ & $\mathrm{MnO} 2$ & 86.94 & 0.0281 & 3.09 & 20.49 \\
\hline Sodium & $8.93 \mathrm{E}-03$ & & & & & \\
\hline Silicon & $7.89 \mathrm{E}-05$ & $\mathrm{Na} 2 \mathrm{O} . \mathrm{Al} 2 \mathrm{O} 3 .(\mathrm{SiO} 2) 2.5 \mathrm{H} 2 \mathrm{O}$ & 374.19 & 0.0148 & 1.62 & 10.78 \\
\hline TOC as Carbon & $4.64 \mathrm{E}-03$ & $\mathrm{Na} 2 \mathrm{C} 2 \mathrm{O} 4$ & 134.00 & 0.3109 & 34.19 & \\
\hline TIC (Carbonate) & $2.37 \mathrm{E}-03$ & $\mathrm{Na} 2 \mathrm{CO} 3 . \mathrm{H} 2 \mathrm{O}$ & 124.00 & 0.2940 & 32.34 & \\
\hline Fluoride & $1.08 \mathrm{E}-03$ & $\mathrm{NaF}$ & 41.99 & 0.0455 & 5.00 & \\
\hline Sulfate & $1.17 \mathrm{E}-04$ & $\mathrm{Na} 2 \mathrm{SO} 4.10 \mathrm{H} 2 \mathrm{O}$ & 322.20 & 0.0376 & 4.13 & \\
\hline Phosphate & $2.21 \mathrm{E}-04$ & $\mathrm{Na} 3 \mathrm{PO} 4.12 \mathrm{H} 2 \mathrm{O}$ & 380.13 & 0.0842 & 9.26 & \\
\hline & & Including Soluble Salts & Total & 0.9093 & 100.00 & \\
\hline & & Without Soluble Salts & Total & 0.1371 & & 100.00 \\
\hline
\end{tabular}

\begin{tabular}{|l|l|l|c|c|}
\hline Recipe & CAS \# & Formula & \multicolumn{2}{c}{ grams/100 grams of solids } \\
\hline & & & 5.1 \\
\hline
\end{tabular}


Hanford Waste Simulants Created to Support Research and

Revision (Date):

\begin{tabular}{|c|c|c|c|}
\hline Calcium Phosphate, tribasic & $12167-74-7$ & $\mathrm{Ca} 3(\mathrm{PO} 4) 2$ & 0.1 \\
\hline Chromic Oxide & $1308-38-9$ & $\mathrm{Cr} 2 \mathrm{O} 3$ & 0.4 \\
\hline Ferric Oxide & $1309-37-1$ & $\mathrm{Fe} 2 \mathrm{O} 3$ & 4.8 \\
\hline Manganese Dioxide & $1313-13-9$ & $\mathrm{MnO} 2$ & 3.1 \\
\hline Sodium Aluminosilicate & & $\mathrm{Na} 2 \mathrm{O} . \mathrm{Al} 2 \mathrm{O} 3 .(\mathrm{SiO} 2) 2.5 \mathrm{H} 2 \mathrm{O}$ & 1.6 \\
\hline Sodium Oxalate & $62-76-0$ & $\mathrm{Na} 2 \mathrm{C} 2 \mathrm{O} 4$ & 34.2 \\
\hline Sodium Carbonate Monohydrate & $5968-11-6$ & $\mathrm{Na} 2 \mathrm{CO} 3 . \mathrm{H} 2 \mathrm{O}$ & 32.3 \\
\hline Sodium Fluoride & $7681-49-4$ & $\mathrm{NaF}$ & 5.0 \\
\hline Sodium Sulfate Decahydrate & $7727-73-3$ & $\mathrm{Na} 2 \mathrm{SO} 4.10 \mathrm{H} 2 \mathrm{O}$ & 4.1 \\
\hline Sodium Phosphate Dodecahydrate & 10101-89-0 & $\mathrm{Na} 3 \mathrm{PO} 4.12 \mathrm{H} 2 \mathrm{O}$ & 9.3 \\
\hline & & Total & 100.0 \\
\hline
\end{tabular}


WESTINGHOUSE SAVANNAH RIVER COMPANY

Hanford Waste Simulants Created to Support Research and Development on the River Protection Project - Waste Treatment Plant
Report:

WSRC-TR-2000-00338

SRT-RPP-2000-00017

Revision (Date): $\quad 0(02 / 22 / 2001)$

Page:

\section{Appendix G Analytical Methods}

\begin{tabular}{|c|c|}
\hline Analyte & Analysis Method* \\
\hline $\mathrm{Ag}$ & ICP-AES \\
\hline $\mathrm{Al}$ & ICP-AES \\
\hline B & ICP-AES \\
\hline $\mathrm{Ba}$ & ICP-AES \\
\hline $\mathrm{Ca}$ & ICP-AES \\
\hline $\mathrm{Ce}$ & ICP-AES \\
\hline $\mathrm{Cr}$ & ICP-AES \\
\hline Cs & ICP-AES, AA \\
\hline $\mathrm{Cu}$ & ICP-AES \\
\hline $\mathrm{Fe}$ & ICP-AES \\
\hline $\mathrm{K}$ & ICP-AES, AA \\
\hline $\mathrm{La}$ & ICP-AES \\
\hline $\mathrm{Mg}$ & ICP-AES \\
\hline $\mathrm{Mn}$ & ICP-AES \\
\hline Mo & ICP-AES \\
\hline $\mathrm{Na}$ & ICP-AES, AA \\
\hline $\mathrm{Nd}$ & ICP-AES \\
\hline $\mathrm{Ni}$ & ICP-AES \\
\hline $\mathrm{P}$ & ICP-AES \\
\hline $\mathrm{Pb}$ & ICP-AES \\
\hline
\end{tabular}

\begin{tabular}{|c|c|}
\hline $\mathrm{Sr}$ & ICP-AES \\
\hline $\mathrm{Zn}$ & ICP-AES \\
\hline $\mathrm{Zr}$ & ICP-AES \\
\hline Chloride & IC \\
\hline Fluoride & IC \\
\hline Formate & IC, HPLC \\
\hline Nitrate & IC \\
\hline Nitrite & IC \\
\hline Oxalate & IC \\
\hline Phosphate & IC \\
\hline Sulfate & IC \\
\hline TIC/TOC & $\mathrm{CO}_{2}$ measurement \\
\hline EDTA & HPLC \\
\hline HEDTA & HPLC \\
\hline Glycolate & HPLC \\
\hline Citrate & HPLC \\
\hline Acetate & HPLC \\
\hline Iminodiacetic Acid & GCMS \\
\hline Hydroxide & Titration \\
\hline Carbonate & Titration \\
\hline
\end{tabular}

Analysis Methods:
ICP-AES
Inductively Coupled Plasma - Atomic Emission Spectrophotometer
AA
IC Atomic Absorption Spectrophotometer
HPLC Ion Chromatography High Performance Liquid Chromatography 
Hanford Waste Simulants Created to Support Research and

Revision (Date):

Page: 


\section{DISTRIBUTION:}

H. F. Strum, 773-A

S. T. Wach, 773-42A

E. W. Holtzscheiter, 773-A

R. H. Spires, 773-A

D. A. Crowley, 773-43A

S. L. Marra, 704-1T

C. T. Randall, 773-42A

R. E. Eibling, 704-1T

T. B. Calloway, 704-1T

E. K, Hansen, 704-1T

M. R. Duignan, 786-5A

D. J. McCabe, 773-42A

W. D. King, 773-42A

M. S. Hay, 773-42A

A. S. Choi, 773-42A

C. L. Crawford, 773-41A

N. M. Hassan, 773-A

H. H. Saito, 773-42A

STI, 703-43A (4 Copies) 